\title{
GEOTHERMAL HYDROLOGY OF VALLES CALDERA AND THE SOUTHWESTERN JEMEZ MOUNTAINS, NEW MEXICO
}

U.S. DEPARTMENT OF THE INTERIOR U.S. GEOLOGICAL SURVEY

Water-Resources Investigations Report 00-4067

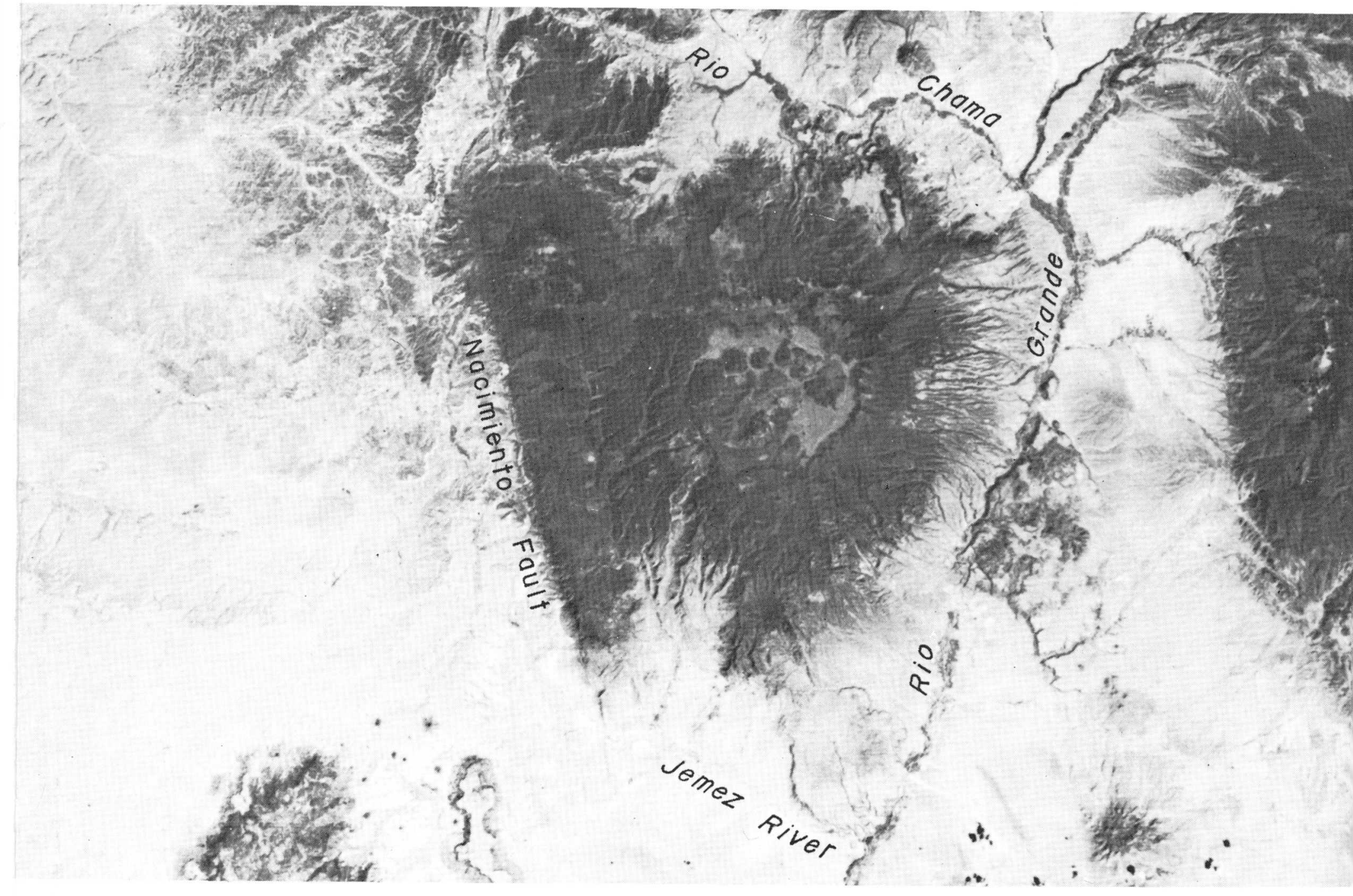

Prepared in cooperation with the OFFICE OF THE STATE ENGINEER 


\section{GEOTHERMAL HYDROLOGY OF VALLES CALDERA AND THE SOUTHWESTERN JEMEZ MOUNTAINS, NEW MEXICO}

By Frank W. Trainer, Robert J. Rogers, and Michael L. Sorey

U.S. GEOLOGICAL SURVEY

Water-Resources Investigations Report 00-4067

Prepared in cooperation with the OFFICE OF THE STATE ENGINEER

Albuquerque, New Mexico 2000 


\title{
U.S. DEPARTMENT OF THE INTERIOR \\ BRUCE BABBITT, Secretary
}

\author{
U.S. GEOLOGICAL SURVEY
}

Charles G. Groat, Director

The use of firm, trade, and brand names in this report is for identification purposes only and does not constitute endorsement by the U.S. Geological Survey.

For additional information write to:

\section{District Chief}

U.S. Geological Survey

Water Resources Division

5338 Montgomery NE, Suite 400

Albuquerque, NM 87109-1311
Copies of this report can be purchased from:

U.S. Geological Survey

Information Services

Box 25286

Denver, CO 80225-0286

Information regarding research and data-collection programs of the U.S. Geological Survey is available on the Internet via the World Wide Web. You may connect to the Home Page for the New Mexico District Office using the URL: http://nm.water.usgs.gov 


\section{CONTENTS}

Page

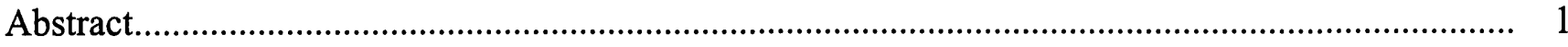

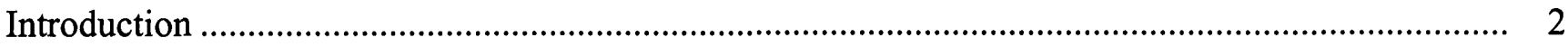

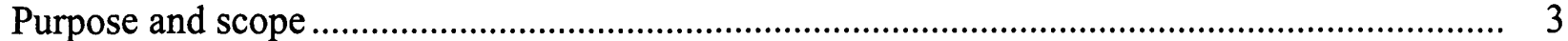

Previous investigations and availability of data ........................................................... 3

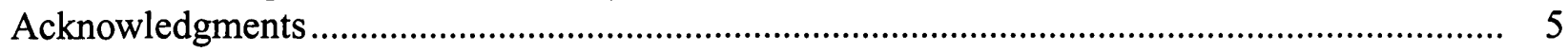

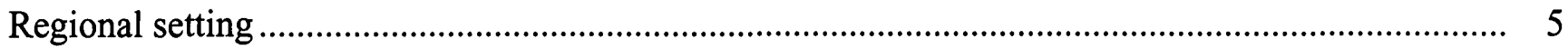

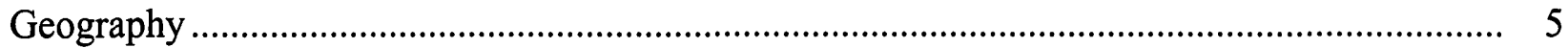

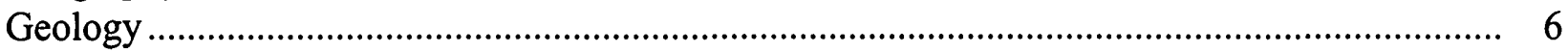

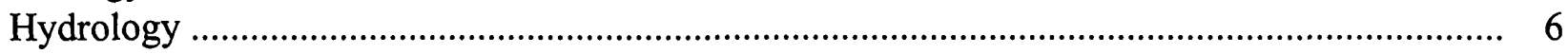

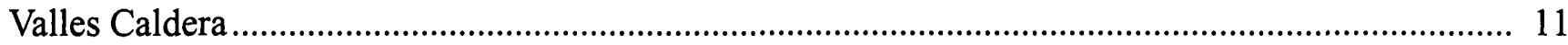

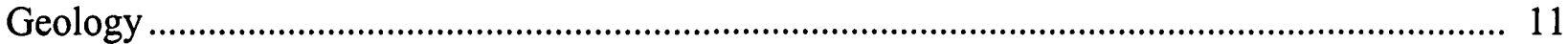

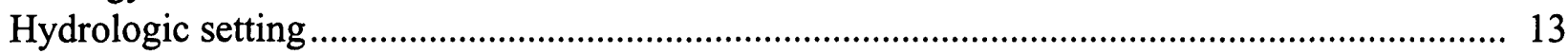

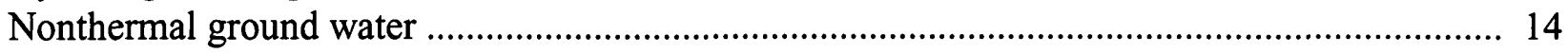

Surface and near-surface geothermal features........................................................ 15

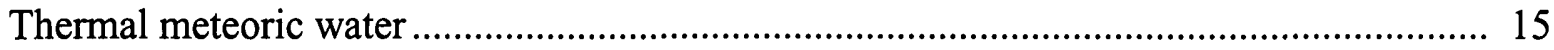

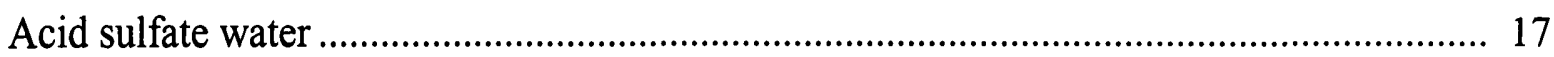

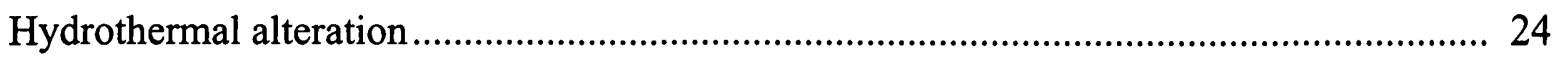

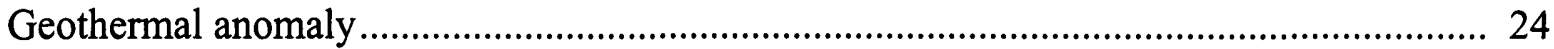

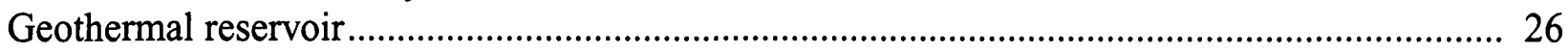

Geometry and hydrologic properties ................................................................... 26

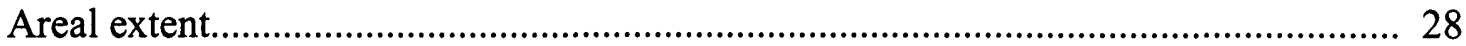

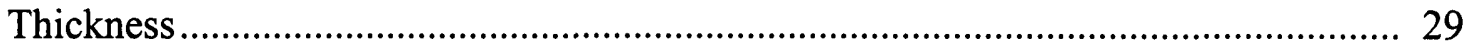

Temperature and pressure distributions ............................................................ 29

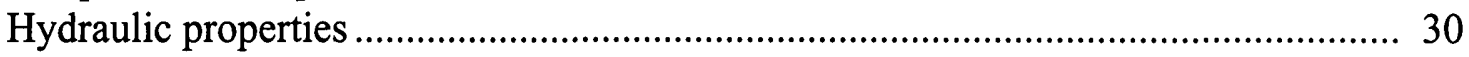

Geochemistry of geothermal fluids.................................................................... 32

Fluid flow in the reservoir ................................................................................... 35

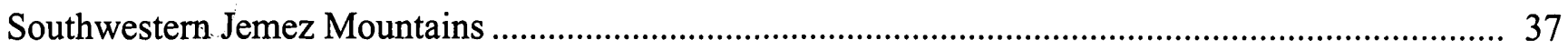

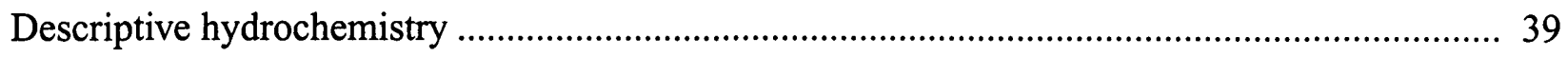

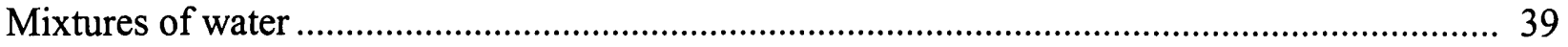

Mineral water near the caldera as derivatives of geothermal fluids ........................................ 46

Mineral water in Cañon de San Diego ......................................................................... 50

Area near rim of caldera ....................................................................................... 53

Jemez Springs and Soda Dam.................................................................................. 58

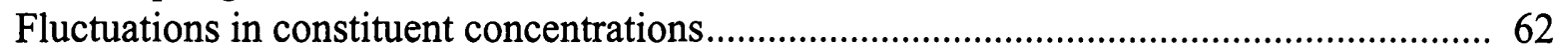

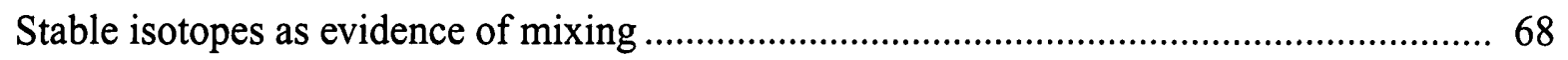

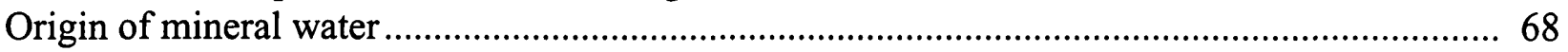

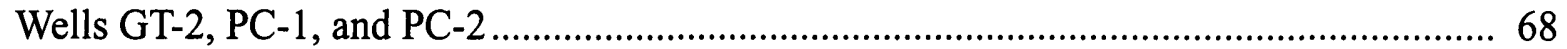

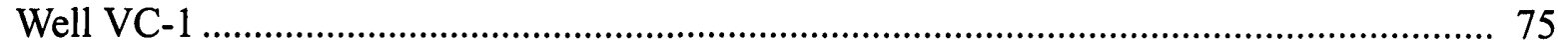

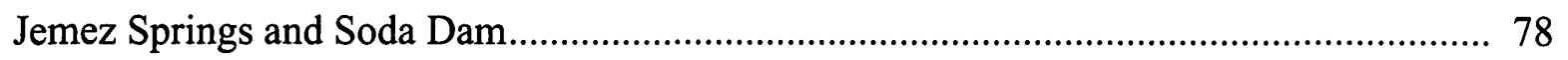


Ground-water system 79

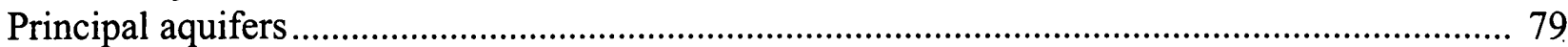

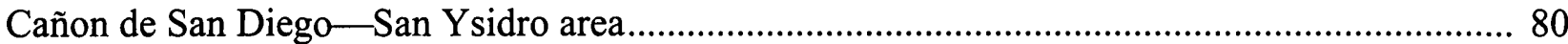

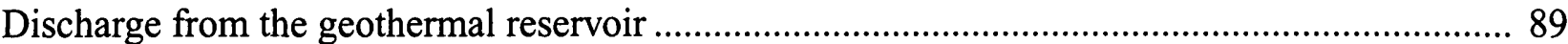

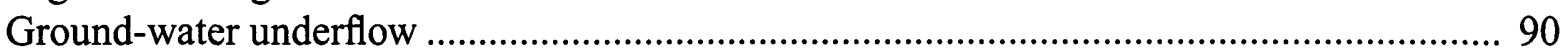

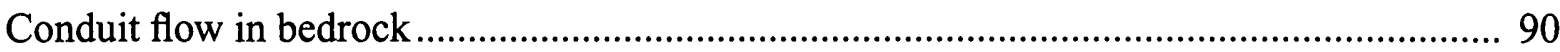

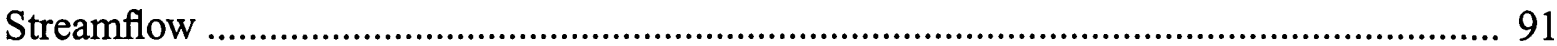

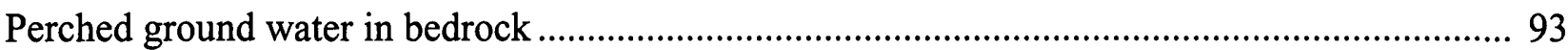

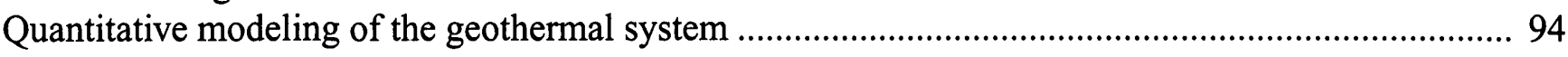

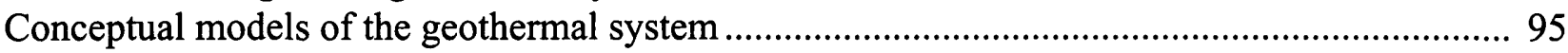

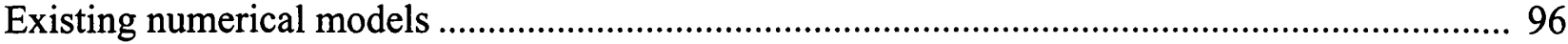

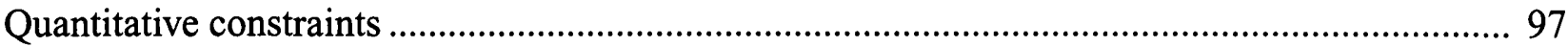

Modeling system response to development .................................................................. 99

Monitoring hydrochemical discharge in the southwestern Jemez Mountains ..................................101

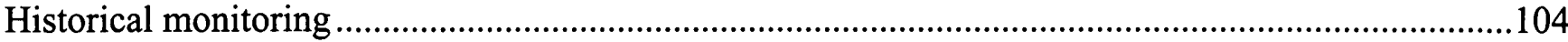

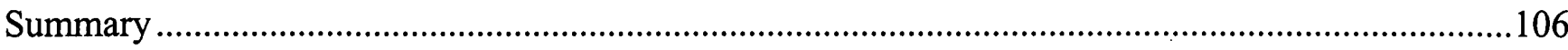

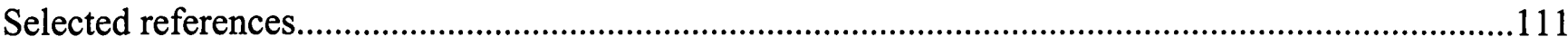

\section{FIGURES}

1-7. Maps showing:

1. Geographic setting of the Jemez Mountains region ................................................ 4

2. Generalized geology of the Jemez Mountains and adjacent Rio Grande

Rift zone.

3. Regional geologic setting of the Jemez Mountains.

4. (A) Geologic features in the Valles Caldera and (B) generalized geologic section of the Valles Caldera.

5. Location of selected geothermal boreholes and hot springs in the Valles Caldera region.

6. Principal streams in the Valles Caldera region and location of discontinued

U.S. Geological Survey streamflow-gaging stations

7. Location of selected sampling sites for deuterium and oxygen-18 data listed in table 4

8. Graph showing deuterium and oxygen-18 data for selected waters in the Jemez

Mountains region

9. Generalized section of the Sulphur Springs area, Valles Caldera .

10. Maps showing (A) areal extent of hydrothermal alteration and the geothermal reservoir and (B) shallow temperature gradients in the Valles Caldera

11. Generalized section of southwestern Valles Caldera and upper Cañon de San Diego showing the active geothermal system

12-25. Graphs showing:

12. Temperature profile of seven Baca wells

13. Range of concentrations of geothermal-reservoir fluids collected in 1982 from five Baca wells

14. Relation of deuterium and oxygen-18 for selected thermal and nonthermal fluids in the Jemez Mountains region. 
15. (A) Major-ion composition and (B) concentrations in water from geothermal wells in the Sulphur Springs and Redondo Creek areas.

16. (A) Major-ion composition and (B) concentrations in water from wells and springs in granitic rocks, volcanic rocks (chiefly rhyolitic and andesitic), and alluvium and colluvium derived from volcanic rocks...

17. (A) Major-ion composition and (B) concentrations in water from wells and springs in the Madera Limestone.

18. (A) Major-ion composition and (B) concentrations in water from wells and springs in the Abo Formation

19. (A) Major-ion composition and (B) concentrations in water from wells and springs in rift-fill deposits (Santa Fe Formation and Zia Sand).

20. Downstream change in major-ion composition of water in the Jemez River system and map showing location of sampling sites.

21. Major-ion composition in ground water in alluvium along the Jemez River and map showing location of sampling sites

22. Concentrations of selected pairs of ions in geothermal-reservoir-fluid samples and in mixed water.

23. Major-ion concentrations in geothermal-reservoir-fluid samples and estimated original concentrations in water from well GT-2....

24. Actual analysis and reconstructed analysis of major ions in water from well PC-1 ......... 51

25. Actual analysis and reconstructed analysis of major ions in water from well VC-1 ......... 52

26. Diagrammatic section showing generalized geohydrologic setting in Cañon de

San Diego.

27-36. Graphs showing:

27. (A) Major-ion composition and (B) concentrations in five ground-water samples from Cañon de San Diego near the rim of Valles Caldera.....

28. Fluctuations in bicarbonate and chloride concentrations and discharge of spring H-32 located near the rim of Valles Caldera, 1973-74.

29. (A,B) Fluctuations in concentrations of selected ions in spring H-32 and

(C) streamflow discharge at Jemez River below East Fork, near Jemez Springs............ 57

30. Ion-concentration and water-level fluctuations in wells H-29 and H-30, 1974

31. (A) Chloride and boron and (B) chloride and sulfate in water from wells and springs in the Valles Caldera and Cañon de San Diego area and (C) map showing location of wells and springs.

32. Actual and reconstructed concentrations of major ions in water from spring H-6 at Soda Dam and spring H-14 at Jemez Springs, 1972.

33. Fluctuations in (A) 2-month running median concentrations of selected ions in springs, 1973-86 and (B) mean monthly streamflow in the Jemez River below East Fork, near Jemez Springs, 1963-76.

34. Covariation of sulfate and chloride in reservoir fluids and in mineral water from the Valles Caldera and Cañon de San Diego.

35. Covariation of deuterium and oxygen-18 in Valles Caldera reservoir fluids and in derivative mixed waters.

36. Covariation of deuterium and oxygen-18 in water from geothermal wells in Valles Caldera and wells VC-1 and GT-2 near the caldera rim 
37. Diagrams and graphs showing concentration of chloride in samples from water-yielding zones penetrated by wells PC-1 and PC-2 ........................................................ 73

38. Graph showing the effect on stable-isotope composition of geothermal-reservoir fluid from addition of small volumes of a hypothetical dilute water to one volume of reservoir water

39. Graphs showing formation of mineral water similar to that in well VC-1 calculated from stable-isotope data for inferred dilute water and geothermal-reservoir fluid.

40. Diagrammatic cross section showing flow paths of reservoir fluid escaping from Valles Caldera.

41. Graph showing (A) Inferred profiles of piezometric surfaces in Cañon de San Diego and map showing (B) approximate water-table contours and generalized direction of ground-water movement in rift-fill deposits.

42-45. Graphs showing:

42. Chloride load at three sites on the Jemez River, 1973-74

43. Ranges in chemical composition of water from wells and springs in the lower

Cañon de San Diego, near San Ysidro

44. Covariation of (A) lithium and chloride and (B) boron and chloride in representative reservoir fluids in Valles Caldera and in mixed water in and near Cañon de San Diego.

45. Covariation of deuterium and oxygen-18 in reservoir fluid in Valles Caldera, derivative water near Cañon de San Diego, and mineral-spring water near

San Ysidro and Jemez Pueblo

46. Diagram showing generalized pressure-altitude relations for liquid-dominated

hydrothermal systems

47. Map showing selected streamflow-gaging stations and periodic-measurement sites

where hydrologic measurements have been made.

48. Graph showing chloride load and sodium chloride molar ratio at the Jemez River below East Fork, near Jemez Springs for 1963-67 and 1971-82

49. Graph showing relation of major-ion composition in water samples from the Jemez River and Rio Guadalupe Basins and wastewater from Fenton Hill drilling sites

\section{TABLES}

1. Generalized stratigraphy of Jemez Mountains in and near Valles Caldera

2. Summary of selected physical data for hot springs and a geothermal well in Valles Caldera...... 16

3. Chemical analyses of thermal meteoric ground water in Valles Caldera................................... 18

4. Deuterium and oxygen-18 isotope data for wells, springs, and streams in the Jemez Mountains region

5. Estimated reservoir properties of the Valles Caldera geothermal reservoir used in numerical simulation models of the reservoir.

6. Chemical data used for estimating original major-ion concentrations of water from well GT-2

7. Chemical analyses of water from well PC-1.

8. Chemical analyses of six ground-water samples, Cañon de San Diego near the rim of Valles Caldera

9. Discharge of the Jemez River upstream and downstream from Soda Dam. 
10. Chemical analyses of mineral water from wells and springs at Jemez Springs and

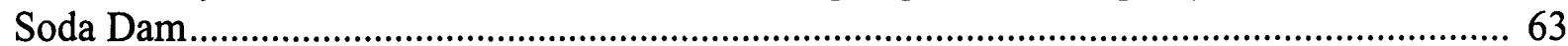

11. Example of degree of dilution calculated for typical mineral-water samples from Jemez

Springs and Soda Dam using two assumed parent reservoir fluids ..................................... 65

12. Isotopic and chloride data for mineral water from wells and springs at Jemez Springs and

Soda Dam

13. Chemical and stable-isotope data for well VC-1

14. Calculated volume of dilute water that, when mixed with a unit volume of geothermal fluid, yields water similar to that in well VC-1

15. Chemical and isotopic analyses of ground water in and near the lower Cañon de

San Diego.

16. Selected streamflow and chloride data and calculations for reach of Jemez River between U.S. Geological Survey streamflow-gaging station Jemez River near Jemez and San Ysidro, March 1, 1984

17. Chemical loads for selected ions in the Rio Grande, Otowi Bridge to Bernalillo ...................... 92

18. Mean daily discharge at selected streamflow-gaging stations, February 11-15, 1974

19. Summary of characteristics and results of existing quantitative models of the Valles hydrothermal system.

20. Selected periodic measurement sites at which streamflow and water-chemistry data have been collected

CONVERSION FACTORS AND VERTICAL DATUM

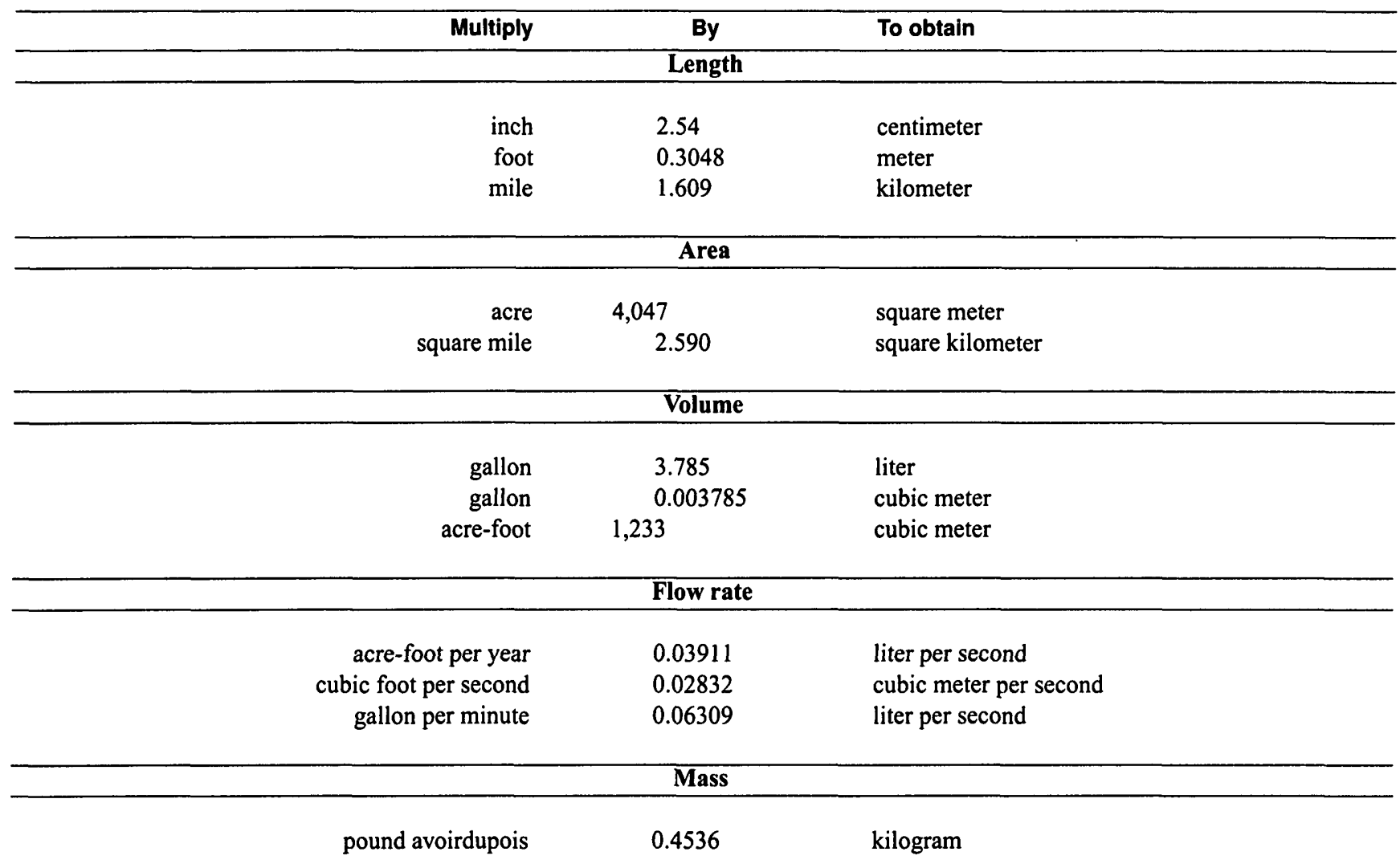




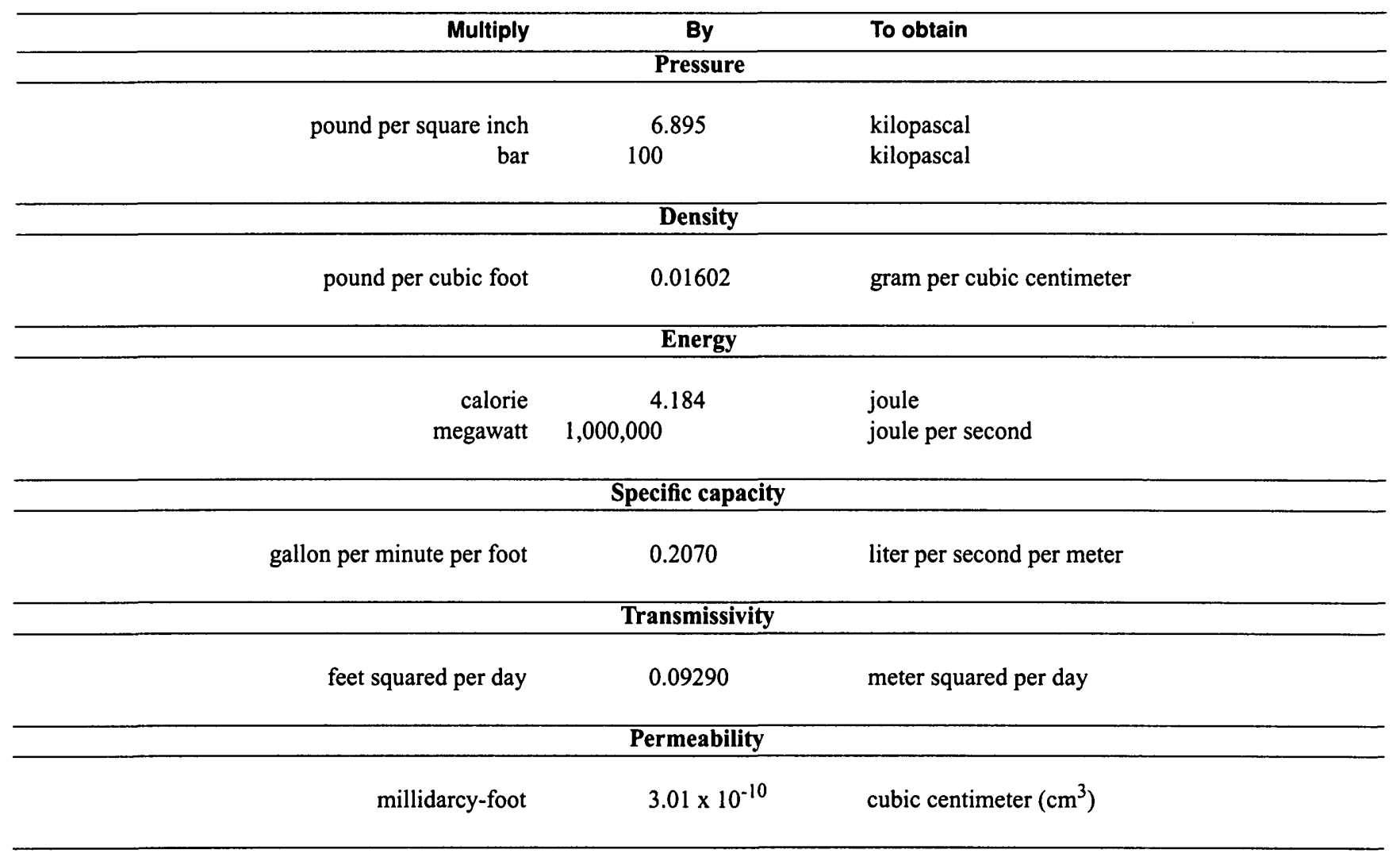

Temperature in degrees Celsius $\left({ }^{\circ} \mathrm{C}\right)$ or degrees Fahrenheit $\left({ }^{\circ} \mathrm{F}\right)$ can be converted by the equations:

$$
\begin{aligned}
& { }^{\circ} \mathrm{F}=\left(1.8 \times{ }^{\circ} \mathrm{C}\right)+32 \\
& { }^{\circ} \mathrm{C}=\left({ }^{\circ} \mathrm{F}-32\right) / 1.8
\end{aligned}
$$

Sea level: In this report, "sea level" refers to the National Geodetic Vertical Datum of 1929—a geodetic datum derived from a general adjustment of the first-order level nets of the United States and Canada, formerly called Sea Level Datum of 1929.

Concentration of stable isotopes in water are expressed in per mil relative to standard mean ocean water (SMOW), the normal reference standard.

Concentration of tritium in water is expressed in tritium units (TU), which equal 3.23 picocuries per kilogram of water.

Heat flow is expressed in heat flow units (HFU), which equal $3 \times 10^{-6}$ calorie per centimeter squared per second. 


\title{
GEOTHERMAL HYDROLOGY OF VALLES CALDERA AND THE SOUTHWESTERN JEMEZ MOUNTAINS, NEW MEXICO
}

\author{
By Frank W. Trainer, Robert J. Rogers, and Michael L. Sorey
}

Abstract

The Jemez Mountains in north-central New Mexico are volcanic in origin and have a large central caldera known as Valles Caldera. The mountains contain the Valles geothermal system, which was investigated during 1970-82 as a source of geothermal energy. This report describes the geothermal hydrology of the Jemez Mountains and presents results of an earlier 1972-75 U.S. Geological Survey study of the area in light of more recent information. Several distinct types of thermal and nonthermal ground water are recognized in the Jemez Mountains. Two types of near-surface thermal water are in the caldera: thermal meteoric water and acid sulfate water. The principal reservoir of geothermal fluids is at depth under the central and western parts of the caldera. Nonthermal ground water in Valles Caldera occurs in diverse perched aquifers and deeper valley-fill aquifers.

The geothermal reservoir is recharged by meteorically derived water that moves downward from the aquifers in the caldera fill to depths of 6,500 feet or more and at temperatures reaching about 330 degrees Celsius. The heated geothermal water rises convectively to depths of 2,000 feet or less and mixes with other ground water as it flows away from the geothermal reservoir. A vapor zone containing steam, carbon dioxide, and other gases exists above parts of the liquid-dominated geothermal zone.

Two subsystems are generally recognized within the larger geothermal system: the Redondo Creek subsystem and the Sulphur Creek subsystem. The permeability in the Redondo
Creek subsystem is controlled by stratigraphy and fault-related structures. Most of the permeability is in the high-angle, normal faults and associated fractures that form the Redondo Creek Graben. Faults and related fractures control the flow of thermal fluids in the subsystem, which is bounded by high-angle faults. The Redondo Creek subsystem has been more extensively studied than other parts of the system. The Sulphur Springs subsystem is not as well defined. The upper vapordominated zone in the Sulphur Creek subsystem is separated from the liquid-dominated zone by about 800 feet of sealed caldera-fill rock. Acid springs occur at the top of the vapor zone in the Sulphur Springs area. Some more highly permeable zones within the geothermal reservoir are interconnected, but the lack of interference effects among some wells during production tests suggests effective hydraulic separation along some subsystem boundaries. Chemical and thermal evidence suggests that the Sulphur Springs subsystem may be isolated from the Redondo Creek subsystem and each may have its own zone of upflow and lateral outflow.

The area of the entire geothermal reservoir is estimated to be about 12 to 15 square miles; its western limit generally is thought to be at the ringfracture zone of the caldera. The top of the reservoir is generally considered to be the bottom of a small-permeability "caprock" that is about 2,000 to 3,000 feet below land surface. Estimated thicknesses to the bottom of the reservoir range from 2,000 to 6,000 feet. Reservoir temperatures measured in exploration wells range from 225 degrees Celsius just below the caprock to about 
330 degrees Celsius in deeper drill holes.

Pressures measured in exploration wells in the

Redondo Creek area ranged from 450 to 1,850 pounds per square inch. Steam-producing zones have been encountered above the liquiddominated zones in wells, but the extent of steam zones is not well defined.

The reservoir contains a near-neutral, chloride-type water containing about 7,000 milligrams per liter dissolved solids. No thermal springs in the caldera have geochemical characteristics similar to those of the geothermal reservoir fluids sampled in wells.

Oxygen-18 and deuterium isotope concentrations of geothermal reservoir fluid indicate a meteoric origin. The moat valleys in the north and east areas of the caldera may be the principal recharge zones of the reservoir. Downward flow along fault zones and fractures probably is the primary mechanism of recharge. Recharge water probably enters the edges of the reservoir at depth, heats up, rises convectively within the reservoir, and discharges laterally to the west and southwest.

Outflowing mineral water appears to be limited to the western and southwestern parts of the Jemez Mountains. Hydrothermal features outside Valles Caldera are restricted largely to Cañon de San Diego. Subsurface escape of reservoir fluid from near and beneath Valles Caldera has formed a discharge plume of reservoir water mixed with dilute ground water, which extends down Cañon de San Diego. The Jemez Fault Zone transports a relatively large portion of this flow. Soda Dam and Jemez Springs are derivatives of geothermal outflow from the reservoir. Near Jemez Pueblo, subsurface mineral water merges with the regional aquifer in fill deposits of the Albuquerque Basin.

Total geothermal discharge from the caldera is difficult to estimate; all estimates based on chemical mass balance suggest a small fluid discharge. About 1.0 cubic foot per second $\left(\mathrm{ft}^{3} / \mathrm{s}\right)$ of caldera-derived geothermal fluid is estimated to be carried by the Jemez River between Jemez Pueblo and San Ysidro, and about $0.4 \mathrm{ft}^{3} / \mathrm{s}$ is estimated to be carried as underflow in the same reach. Estimates of total discharge from the geothermal reservoir to the Rio Grande at its confluence with the Jemez River range from 2.0 to $3.6 \mathrm{ft}^{3} / \mathrm{s}$.

Numerical models of the geothermal system range in complexity from one-dimensional, single-phase fluid-flow models to threedimensional, multiphase-fluid and heat-flow models. The models have been developed primarily to assess reservoir productivity and longevity and potential effects of development on thermal-water discharge in the Jemez River. A period of actual geothermal development, in which the system is stressed and the hydrologic changes are measured, is needed to calibrate or test the models. Existing models must be considered preliminary and cannot provide accurate answers to questions involving long-term changes to the geothermal system. No existing models account for the presence of carbon dioxide in reservoir fluid, which appears to be sufficient to markedly extend the depth over which two-phase conditions occur naturally and possibly to influence reservoir drawdown during development. Development of geothermal energy in Valles Caldera would probably change the hydrochemical discharge from the southwestern Jemez Mountains. Quantifying such changes through systematic monitoring would be valuable in better understanding the geothermal system and in testing, refining, and calibrating numerical models of the system.

\section{INTRODUCTION}

The Valles Caldera in the Jemez Mountains of north-central New Mexico (fig. 1) contains a geothermal system that has been investigated as a source of geothermal energy. This geothermal system has long been known from its thermal springs and fumaroles, but serious consideration of geothermal development did not begin until the early 1960's, when a test well being drilled for oil in the caldera yielded steam. The history of geothermal exploration that followed was summarized by Goldstein and others (1982). Geothermal exploration began in the 1960's with the drilling of four exploratory holes in the 
Sulphur Springs area in the western part of the caldera. The potential of the geothermal system as an energy source was confirmed in 1970 with the drilling of a discovery well (Baca 4) in the Redondo Creek area of the caldera, southeast of Sulphur Springs. In 1971, Union Oil Company leased about 100,000 acres of privately owned land known as Baca Location No. 1

(fig. 1) and began an active drilling program. Because most exploration was on the Baca property, the geothermal system is commonly referred to as the Baca geothermal field or reservoir; in this report, however, it is referred to as the Valles geothermal system. In 1978, the U.S. Department of Energy (DOE), Public Service Company of New Mexico (PNM), and Union Oil Company entered into a cooperative agreement to develop a 50-megawatt demonstration power plant at the Baca 4 site. In 1981, however, Union notified DOE and PNM that it could not locate sufficient steam to support a power plant. A modified program to test hydraulic fracturing of two marginal wells and drilling deeper wells was attempted with disappointing results, and in 1982 the project was terminated. Altogether, Union drilled more than 20 holes (referred to as the Baca wells) in the central and western parts of Valles Caldera, most in the Redondo Creek area, prior to terminating the project.

A range of geologic, geophysical, and hydrologic studies were conducted, principally by university and government scientists, during and subsequent to the period of active geothermal exploration in the Jemez Mountain region. This study, in cooperation with the Office of the State Engineer, was conducted during 1972-75 as part of the U.S. Geological Survey (USGS) geothermal research program. The Jemez Mountains region was selected for geohydrologic investigation by the USGS because exploratory drilling was in progress to evaluate the possibility of geothermal development in the region, and geohydrologic information would be of practical value. The region had been mapped geologically (Smith and others, 1970), but little was known about the geohydrology of hot-water geothermal systems in calderas such as the Valles Caldera.

The objectives of the 1972-75 USGS

investigation were to (1) describe the geohydrology of the region; (2) examine the application of hydrologic methods to the study of a hot-water geothermal system; and (3) gather baseline hydrologic data to aid in identifying future hydrologic effects of geothermal exploration and development. To maintain suitable water quality and quantity in the region, a better understanding is needed of the effects of the geothermal system in the caldera on ground water in the surrounding region. This investigation dealt primarily with areas of the Jemez Mountains outside the caldera because at the time this investigation was conducted, Union Oil Company had leased nearly the entire caldera and was not releasing information from its exploration activities.

\section{Purpose and Scope}

This report presents the results of the 1972-75 USGS investigation of the geothermal hydrology of the Jemez Mountains region and discusses and reinterprets those results in light of more recent work and current (1996) understanding of the Valles geothermal system. The report also describes a conceptual geohydrologic model of the system and summarizes the results of previous hydrologic and geothermal studies of numerical simulations of heat and fluid flow in the geothermal and surrounding hydrologic systems.

The area described in the report is limited to the Jemez Mountains that contain geothermal water-specifically Valles Caldera, which contains the principal geothermal reservoir-and the southwestern Jemez Mountains region outside the caldera, which receives discharge from the geothermal reservoir and was the focus of the 1972-75 investigation.

\section{Previous Investigations and Availability of Data}

Previous investigations of the hydrology and geology of the Jemez Mountains region have focused on the region's extraordinary volcanic geology, its active and accessible geothermal system, the prospective development of this geothermal system as an energy source, and the potential environmental and hydrological effects of such development. When Union Oil Company entered into a cooperative agreement with the DOE in 1978, large amounts of information gathered on the caldera were made publicly available, and many scientific papers about the area were written. In the mid-1980's after geothermal exploration in the caldera ended, the geothermal system of Valles Caldera was investigated by the Continental Scientific Drilling Program (CSDP) of the National Academy of Sciences, which drilled three deep holes in the western 


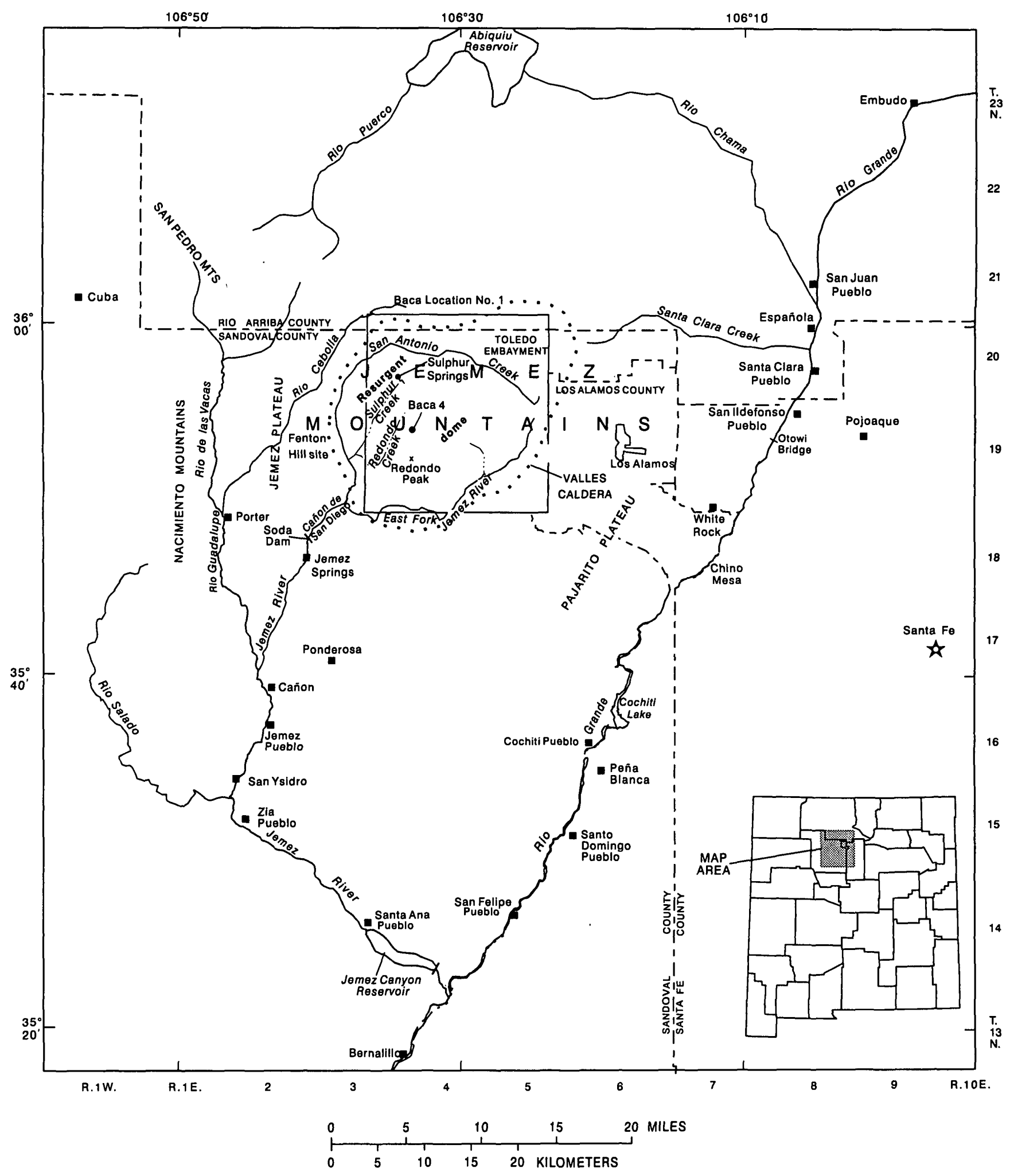

Figure 1.--Geographic setting of the Jemez Mountains region (modified from Self and others, 1996, fig.V2b). 
and southwestern parts of the caldera. Manifestations of anomalous heat flow in the western Jemez

Mountains outside the caldera also have lead to drilling and research in this area. The use of geothermal heat to generate electricity by circulating fluid through a system of wells completed in manmade fractures in hot dry rock has been studied by the Los Alamos National Laboratory (LANL) at the Fenton Hill site just west of the caldera (fig. 1). The volume of data and scientific literature from these investigations is too large to summarize in detail; however, many important sources of information are contained in an annotated bibliography of the hydrology, geology, and geothermal resources of the Jemez Mountains region (Abeyta and Delaney, 1986), which covers the period through 1985. Two issues containing special sections on research in the Valles Caldera were published in Journal of Geophysical Research $(1986,1988)$. Hydrologic data for the Jemez Mountains region are included in USGS reports (1963-83), Trainer (1978), Union Oil Company of California and Public Service Company of New Mexico (1978), Goff and others (1982), Craigg (1984), Shevenell and others (1987), and Abeyta and Delaney (1990). Conover and others (1963), Griggs (1964), Purtymun and Cooper (1969), Dondanville (1971, 1978), Trainer $(1974,1978,1984)$, Goff and Grigsby (1982), and Goff and others (1988) described aspects of the hydrology of the region. The geochemistry of thermal water in the region and its derivatives have been discussed by Goff and others (1981), White and others (1984), Goff and others (1985), Truesdell and Janik (1986), Vuataz and Goff (1986), White (1986), and Shevenell and others (1987). Bodvarsson and others (1982), Faust and others (1984), and Grant and others (1984) developed conceptual and numerical simulation models of the geothermal system. Findings from holes drilled by the CSDP were summarized by Goff and others (1992) and discussed in detail by workers cited therein.

The entire Jemez Mountains region has been studied geologically. The western part of the region with special reference to sedimentary rocks was studied by Wood and Northrop (1946). Gardner and others (1986) and Smith and others (1970) studied the entire region with emphasis on volcanic rocks. The valley-fill deposits were investigated by Galusha and Blick (1971), and the tectonics of the region were reported by Aldrich (1986). The caldera and associated volcanism have been investigated by Nielson and Hulen (1984), Heiken and others (1986), and Self and others (1986). Reiter and others (1975) and Swanberg (1983) mapped heat flow and temperature gradients in the region.

\section{Acknowledgments}

The 1972-75 USGS investigation of the Jemez Mountains region benefited from the cooperation of individuals, government agencies, and pueblos. Acknowledgments are extended to private land owners of the region, the holders of mineral rights in the Cañon de San Diego Grant, the governors and councils of Jemez Pueblo and Zia Pueblo, LANL, the New Mexico Department of Game and Fish, and the U.S. Forest Service for access to and information about wells and springs; to Union Oil Company of California for the opportunity to collect and publish water-quality data for well Baca 4; and to Ivan Barnes, R.L. Borton, R.O. Fournier, F.E. Goff, W.E. Hale, J.L. Kunkler, R.H. Mariner, R.M. McBreen, Kim Ong, T.S. Presser, W.D. Purtymun, C.S. Smith, A.H. Truesdell, F.G. West, and D.E. White for assistance in and discussion of the investigation.

\section{REGIONAL SETTING}

\section{Geography}

The Jemez Mountains encompass about 1,500 square miles $\left(\mathrm{mi}^{2}\right)$ in north-central New Mexico in Los Alamos, Rio Arriba, Sandoval, and Santa Fe Counties (fig. 1). The mountains form an oval topographic mound that contains a central caldera, or area of collapse, which is the most prominent feature of the mountains. The outer flanks of the caldera are surrounded by a series of plateaus dissected by narrow, deep canyons. The mountain mass is bounded by the principal streams that drain the region (fig. 1): the Rio Chama and Rio Puerco to the north, the Rio Grande to the east and southeast, and the Jemez River and tributaries to the south and west. The western boundary of the mountains joins the Nacimiento Mountains and consequently is not as clearly defined as the others. The highest point in the Jemez Mountains is Redondo Peak, 11,254 feet (ft) above sea level (fig. 1).

Records of precipitation and temperature at several stations in and near the Jemez Mountains are published by the National Oceanic and Atmospheric 
Administration. Mean annual precipitation in the lower country surrounding the mountain mass ranges from about 8 inches (in.) at the southern edge to 12 in. or more at the northern edge. Mean annual precipitation is about 18 in. at Los Alamos and about 17 in. at Jemez Springs. At both locations, approximately two-thirds of the annual precipitation falls during the 6-month period April through September (Kunkel, 1984). Annual precipitation at the higher altitudes near the center of the region, where few measurements have been made, is estimated from isohyetal analyses and topographic data to be greater than 30 in. (U.S. Soil Conservation Service, 1972). Most precipitation at the higher altitudes falls as snow, which lasts several months in winter and early spring. Vegetation ranges from desert plants in the areas surrounding the mountains to dense forests of conifers and aspen in the high country.

Nearly the entire caldera, or the central part of the mountains, is within the 100,000 -acre Baca Location No. 1 (fig. 1). Most land outside the land grant is in public domain, administered principally by the U.S. Forest Service and the DOE. Small areas are administered by the New Mexico Department of Game and Fish and the National Park Service. Indian tribes own large tracts in peripheral parts of the region.

The total population of the Jemez Mountains region is probably less than 25,000. Most inhabitants live in Los Alamos and White Rock, which had populations of about 11,850 and 6,200, respectively, in 1990. Several small villages (Jemez Springs, Cañon, Ponderosa, and San Ysidro) are in the southwestern part of the region, and eight Indian pueblos (Jemez, Zia, Santa Ana, San Felipe, Santo Domingo, Cochiti, San Ildefonso, and Santa Clara) are situated along the Jemez River and Rio Grande. Santa Fe is located about 30 miles ( $\mathrm{mi}$ ) to the southeast.

\section{Geology}

The Jemez Mountains are a complex mass of Tertiary and Quaternary volcanic rocks that overlie Tertiary, Mesozoic, and Paleozoic sedimentary rocks, which in turn overlie Precambrian basement rock (fig. 2; table 1). The volcanic field, which began forming about 13 million years ago (13 Ma), is located near the intersection of the Jemez Lineament and part of the western margin of the Rio Grande Rift (fig. 3).

The Jemez Lineament is a northeast-trending chain of volcanic features extending from east-central Arizona to southeastern Colorado (Aldrich, 1986).
Formation of the Jemez volcanic field occurred as the result of two explosive eruptions that formed two calderas, Toledo Caldera and Valles Caldera, and led to the deposition of the Bandelier Tuff. The formation of the Valles Caldera, about 1.12 Ma, obliterated much of the older Toledo Caldera, which formed about 1.47 Ma. Heiken and others (1986) concluded that the Toledo Caldera was nearly coincident with the Valles Caldera and that the Toledo Embayment to the northeast (fig. 4A)-originally thought to be part of the Toledo Caldera - is a tectonic feature or remnant of a smaller, even older caldera. The Valles geothermal system is located in the central and western parts of the Valles Caldera but does not extend under the entire caldera (Hulen and Nielson, 1986; Wilt and Vonder Harr, 1986). Extensive sheets of the Bandelier Tuff (fig. 4B) overlie the older rocks throughout much of the region, inside and outside the caldera, and form radially dissected plateaus that slope away from the caldera. West of the Rio Grande Rift the tuff overlies Precambrian crystalline rocks, Paleozoic and Mesozoic strata, and Tertiary volcanic rocks; within the Rio Grande Rift the tuff overlies Quaternary and Tertiary rocks (table 1).

Two major fault zones have a substantial influence on the hydrology of the region (Vuataz and Goff, 1986). The Pajarito Fault Zone is east of the caldera and forms the west side of the Rio Grande Rift. The Jemez Fault Zone in Cañon de San Diego intersects the southwestern rim of the caldera (fig. 4A). The Jemez Fault Zone is an expression of the Jemez Lineament, as are faulted structures crossing the resurgent dome and possibly the Toledo Embayment to the northeast (Self and others, 1986).

\section{Hydrology}

The Jemez Mountains are in the Rio Grande drainage basin. The topographic rim of Valles Caldera serves as a drainage divide and forms a near-circular drainage basin with a surface outlet on the southwest where the rim is breached. San Antonio Creek and the East Fork Jemez River are the principal streams draining the caldera, and they join near the southwest rim to form the Jemez River, which flows down Cañon de San Diego, turns southeastward, and eventually joins the Rio Grande (fig. 1). Outside the caldera rim, streams flow radially outward to the principal drainages surrounding the mountains, the Rio Puerco, Rio Chama, Rio Grande, Jemez River, and Rio Guadalupe. 

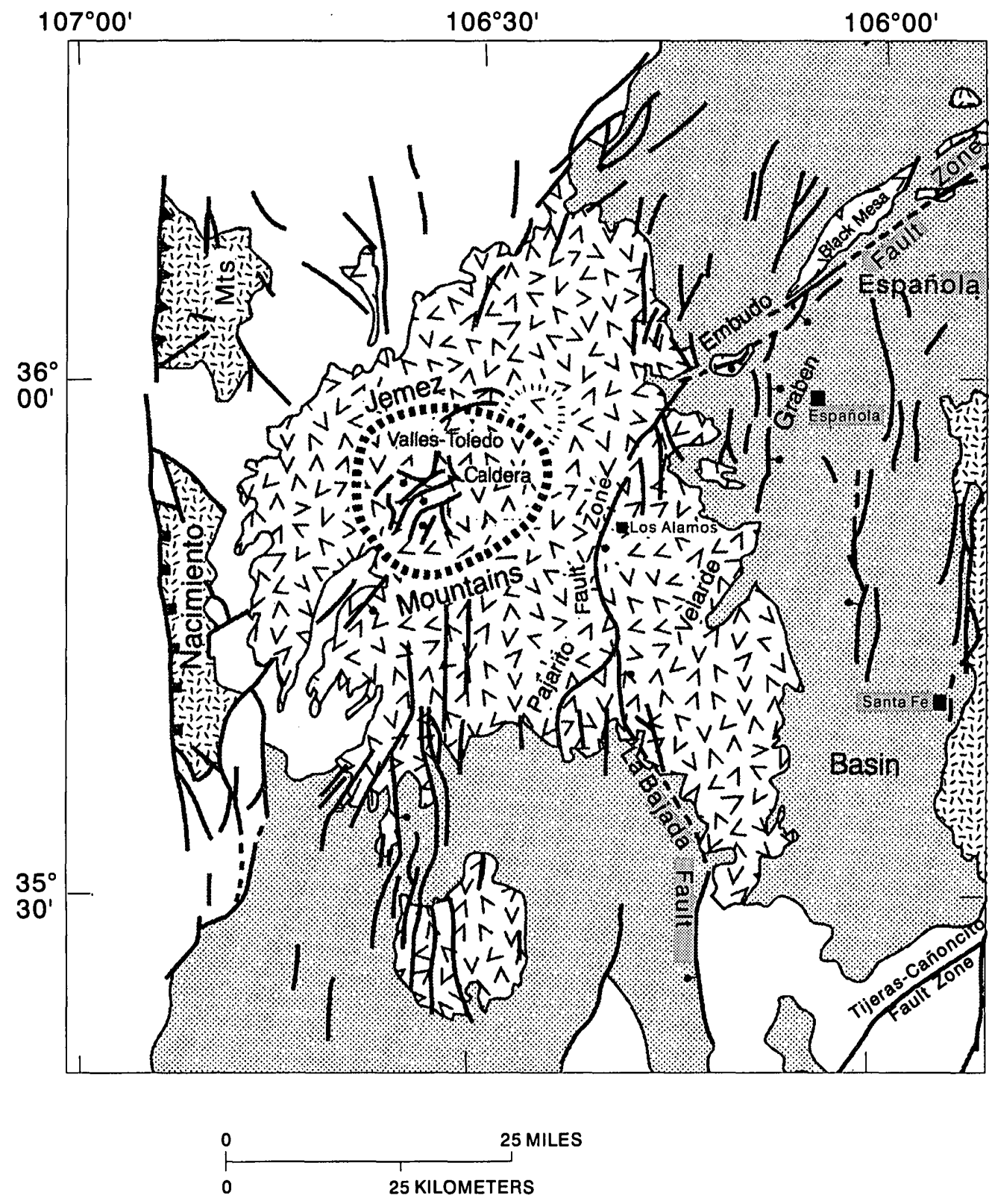

\section{EXPLANATION}
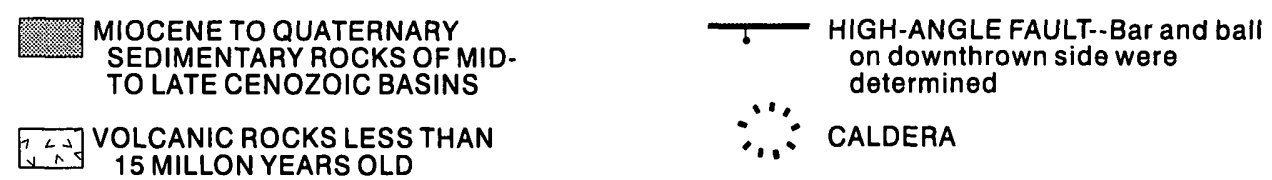

MISSISSIPPIAN TO EARLY MIOCENE

SEDIMENTARY ROCKS, INTRUSIONS, AND VOLCANIC ROCKS

EI:- PRECAMBRIAN ROCKS

Figure 2.--Generalized geology of the Jemez Mountains and adjacent Rio Grande Rift zone (modified from Self and others, 1996, fig. V2a). 
Table 1. Generalized stratigraphy of Jemez Mountains in and near Valles Caldera

[Sources of data: consolidated, nonvolcanic rocks outside Valles Caldera, Wood and Northrop (1946, sec. 4); volcanic rocks, Smith and others (1961). In Valles Caldera, Conover and others (1963); Smith and others (1970); Nielson and Hulen (1984); Wilt and Vonder Haar (1986, fig. 3).

Valley-fill deposits (in rift), Griggs (1964); Galusha and Blick (1971)]

\begin{tabular}{|c|c|c|c|c|c|c|c|}
\hline Era & Period & Group & Jemez Plateau & \multicolumn{2}{|c|}{ Valles Caldera } & \multicolumn{2}{|c|}{ Rio Grande Rift } \\
\hline \multirow{11}{*}{ Cenozoic } & \multirow{5}{*}{ Quaternary } & \multirow{3}{*}{$\begin{array}{l}\text { Tewa } \\
\text { Group }\end{array}$} & $\begin{array}{l}\text { Alluvial and } \\
\text { landslide deposits; } \\
\text { travertine }\end{array}$ & \multicolumn{2}{|c|}{$\begin{array}{l}\text { Alluvial, landslide, } \\
\text { and lacustrine deposits }\end{array}$} & \multicolumn{2}{|c|}{$\begin{array}{l}\text { Alluvial, landslide, and } \\
\text { lacustrine deposits }\end{array}$} \\
\hline & & & & $\begin{array}{l}\text { Valles Rhy } \\
\text { caldera-fill }\end{array}$ & $\begin{array}{l}\text { e and } \\
\text { posits }\end{array}$ & & \\
\hline & & & Bandelier Tuff & $\begin{array}{l}\text { Bandelier } \\
\text { equivalent } \\
\text { rocks }\end{array}$ & $\begin{array}{l}f \text { and } \\
\text { lcanic }\end{array}$ & $\begin{array}{l}\text { Bandelier Tuff and } \\
\text { volcanic rocks }\end{array}$ & quivalent \\
\hline & & \multirow{3}{*}{$\begin{array}{l}\text { Polvadera } \\
\text { Group }\end{array}$} & & & & $\begin{array}{l}\text { El Rechuelos } \\
\text { Rhyolite }\end{array}$ & \multirow{3}{*}{$\begin{array}{l}\text { Puye } \\
\text { Formation }\end{array}$} \\
\hline & & & $\begin{array}{l}\text { Tschicoma } \\
\text { Formation }\end{array}$ & $\begin{array}{l}\text { Tschicoma } \\
\text { Formation }\end{array}$ & $\begin{array}{l}\text { "Lower } \\
\text { tuffs" }\end{array}$ & $\begin{array}{l}\text { Tschicoma } \\
\text { Formation }\end{array}$ & \\
\hline & \multirow{6}{*}{ Tertiary } & & & & & Lobato Basalt & \\
\hline & & \multirow{5}{*}{$\begin{array}{l}\text { Keres } \\
\text { Group }\end{array}$} & & & & Bearhead Rhyolite & \multirow{3}{*}{$\begin{array}{l}\text { Cochiti } \\
\text { Formation }\end{array}$} \\
\hline & & & $\begin{array}{l}\text { Paliza Canyon } \\
\text { Formation }\end{array}$ & \multicolumn{2}{|c|}{$\begin{array}{l}\text { Paliza Canyon } \\
\text { Formation }\end{array}$} & $\begin{array}{l}\text { Paliza Canyon } \\
\text { Formation }\end{array}$ & \\
\hline & & & & & & $\begin{array}{l}\text { Canovas Canyon } \\
\text { Rhyolite }\end{array}$ & \\
\hline & & & $\begin{array}{l}\text { Basalt of Chamisa } \\
\text { Mesa }\end{array}$ & & & & \\
\hline & & & & $\begin{array}{l}\text { Santa Fe } \\
\text { Group }\end{array}$ & $\begin{array}{l}\text { Abiquiu } \\
\text { Tuff }\end{array}$ & $\begin{array}{l}\text { Santa Fe Group } \\
\text { Zia Sand }\end{array}$ & $\begin{array}{l}\text { Abiquiu } \\
\text { Tuff }\end{array}$ \\
\hline Mesozoic & Triassic & & Chinle Formation & & & & \\
\hline \multirow{2}{*}{ Paleozoic } & Permian & & $\begin{array}{l}\text { San Andres, Yeso, } \\
\text { and Abo } \\
\text { Formations }\end{array}$ & \multicolumn{2}{|c|}{ Abo Formation } & & \\
\hline & $\begin{array}{l}\text { Carbon- } \\
\text { iferous }\end{array}$ & $\begin{array}{l}\text { Magda- } \\
\text { lena } \\
\text { Group }\end{array}$ & $\begin{array}{l}\text { Madera Limestone } \\
\text { Sandia Formation }\end{array}$ & \multicolumn{2}{|c|}{ Madera Limestone } & & \\
\hline $\begin{array}{c}\text { Pre- } \\
\text { cambrian }\end{array}$ & & & Granitic rocks & \multicolumn{2}{|c|}{ Granitic rocks } & & \\
\hline
\end{tabular}




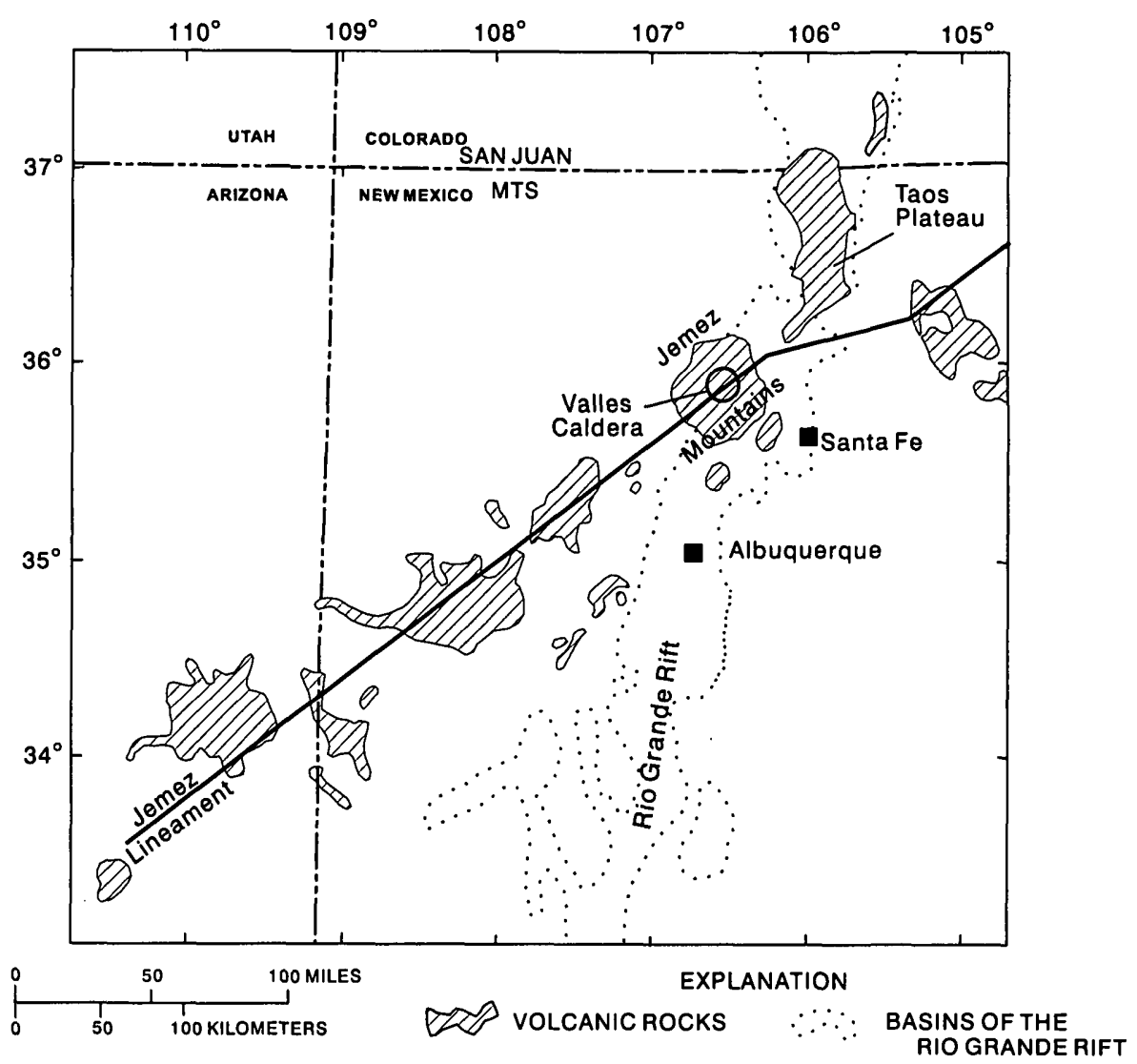

Figure 3.--Regional geologic setting of the Jemez Mountains (modified from Goff and Shevenell, 1987, fig. 1).

Selected USGS streamflow-gaging stations in the Jemez Mountains area are shown below.

\begin{tabular}{|c|c|c|}
\hline Station number & Station name & Period of record (inclusive) \\
\hline 08290000 & Rio Chama near Chamita & October 1912 to present \\
\hline 08313000 & Rio Grande at Otowi Bridge & $\begin{array}{l}\text { February } 1895 \text { to December } \\
\text { 1905; } \\
\text { June } 1909 \text { to present }\end{array}$ \\
\hline 08319945 & Redondo Creek near Jemez Springs & $\begin{array}{l}\text { November } 1981 \\
\text { to September } 1985\end{array}$ \\
\hline 08319950 & Sulphur Creek near Jemez Springs & $\begin{array}{l}\text { November } 1981 \\
\text { to September } 1985\end{array}$ \\
\hline 08321500 & $\begin{array}{l}\text { Jemez River below East Fork, } \\
\text { near Jemez Springs }\end{array}$ & $\begin{array}{l}\text { July } 1949 \text { to October } 1950 \text {; } \\
\text { May } 1951 \text { to September } \\
\text { 1957; March } 1958 \text { to } \\
\text { September } 1976 \text {; July } 1981 \\
\text { to September } 1990\end{array}$ \\
\hline 08323000 & Rio Guadalupe at Box Canyon & $\begin{array}{l}\text { May } 1958 \text { to September } \\
1976 \\
\text { July } 1981 \text { to September } 1996\end{array}$ \\
\hline 08324000 & Jemez River near Jemez & March 1953 to present \\
\hline
\end{tabular}

The Rio Chama enters the Rio Grande about 3.5 mi north of Española. Mean annual flow at the Chamita gage (08290000), just upstream from its confluence with the Rio Grande, was 612 cubic feet per second $\left(\mathrm{ft}^{3} / \mathrm{s}\right)$ for water years 1971-98. Upstream from the gage, flow of the Rio Chama is regulated by reservoirs and irrigation diversions. The mean annual flow of the Rio Grande at Otowi Bridge (08313000) was 1,580 $\mathrm{ft}^{3} / \mathrm{s}$ for water years 1971-98. Upstream from the gage, flow is regulated by reservoirs on the Rio Chama and irrigation diversions. The mean annual flow of the Rio Guadalupe at Box Canyon (08323000) was $54.5 \mathrm{ft}^{3} / \mathrm{s}$ for water years 1982-96. The gaging station is located $4.8 \mathrm{mi}$ upstream from the confluence of the Rio Guadalupe and the Jemez River. The flow of the Rio Guadalupe is regulated by a small reservoir upstream from the gage and irrigation diversions. Mean annual flow of the Jemez River near Jemez (08324000), which is $0.7 \mathrm{mi}$ downstream from the confluence with the Rio Guadalupe, was $79.6 \mathrm{ft}^{3} / \mathrm{s}$ for water years 1954-98. Flow at the station is affected by upstream irrigation diversions.

Similarly to surface water, ground water flows radially outward from the rim of the caldera. The most extensive and productive aquifer in the region is the thick sequence of valley-fill deposits and interbedded volcanic rocks underlying the Pajarito Plateau on the east side of the mountain mass. The caldera contains both thermal and nonthermal ground water and both types discharge from the caldera to the southwest down Cañon de San Diego, which follows the trace of the Jemez Fault Zone. The principal geothermal reservoir, or aquifer, in the region is located under the central and western parts of the caldera. 


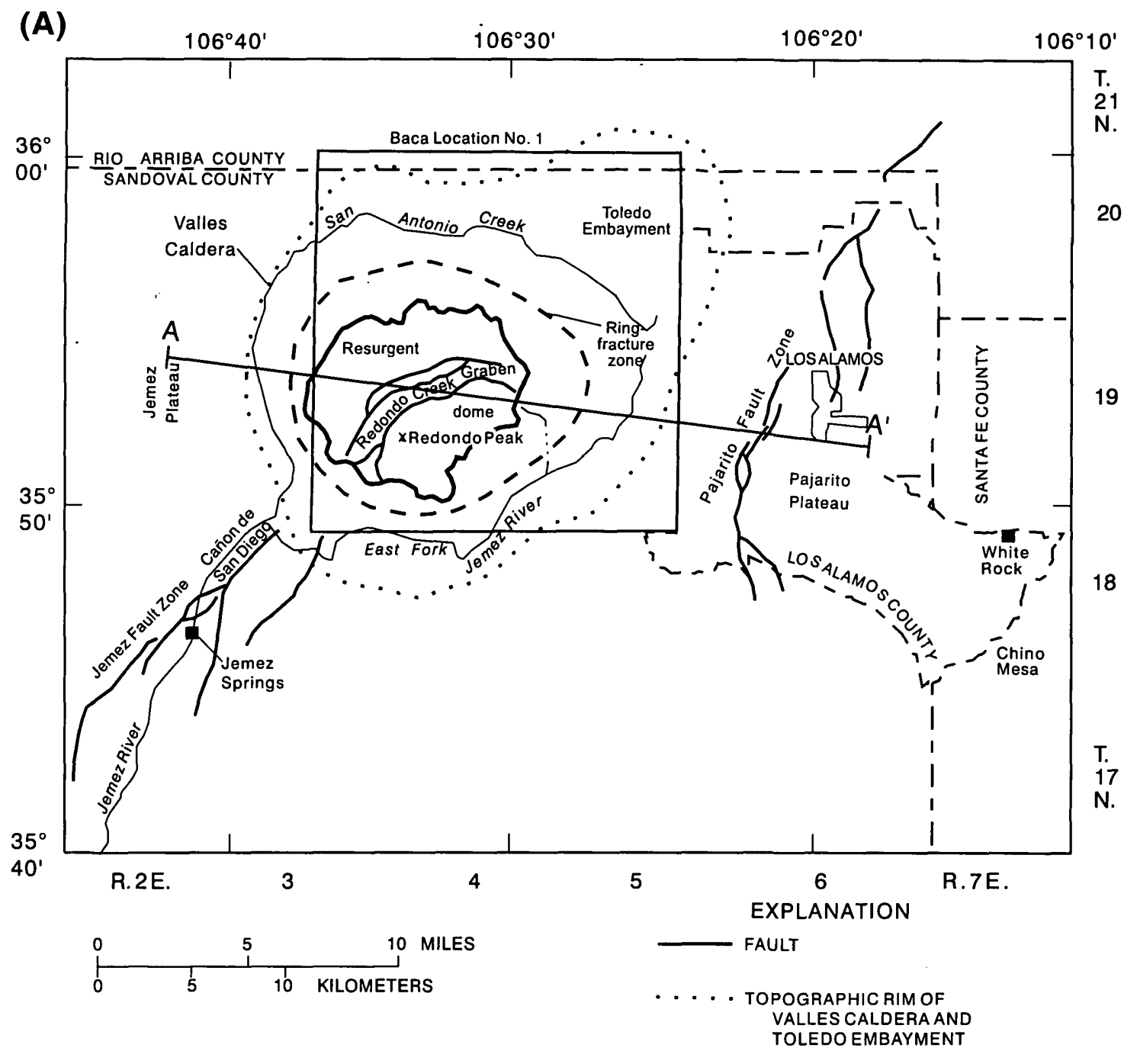

(B) Valles Caldera

A

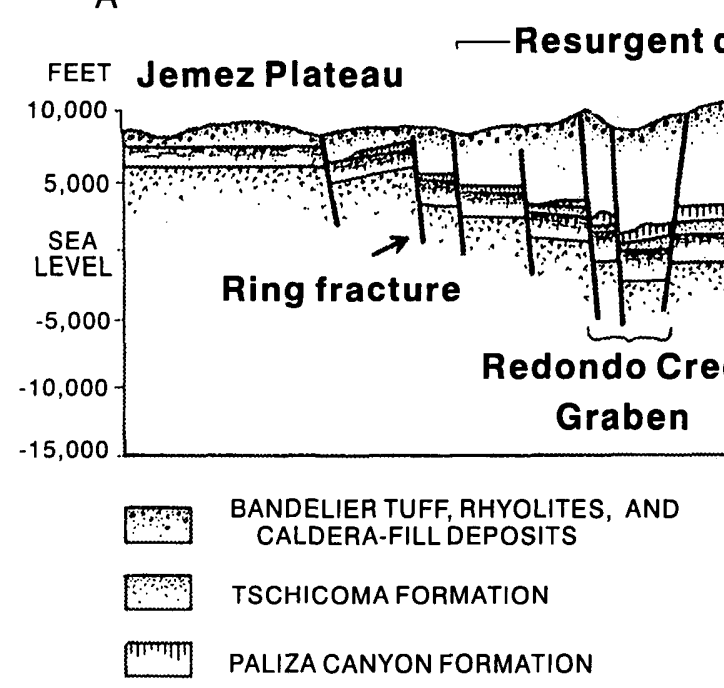

Figure 4.--(A) Geologic features in the Valles Caldera (based on Smith and others, 1970) and (B) generalized geologic section of the Valles Caldera (modified from Vuataz and Goff, 1986). 


\section{VALLES CALDERA}

The Valles Caldera lies in the center of the Jemez Mountains and is one of the most prominent physiographic features in New Mexico. The caldera is approximately circular, and its topographic rim ranges from about 14 to $18 \mathrm{mi}$ in diameter. In this report the Valles Caldera includes the Toledo Embayment on the northeast side of the caldera (fig. 4A). The caldera rim is breached on the southwest side at Cañon de San Diego.

\section{Geology}

The geologic history of Valles Caldera was cited by Smith and Bailey (1968, p. 617-621) as a model for the general sequence of events in caldera and resurgent dome development. They distinguished seven stages of caldera development: (1) regional doming of an existing volcanic upland and the formation of ring fractures above the magma chamber, (2) eruption of ash from the ring-fracture system, (3) collapse of the roof of the magma chamber and subsidence of the circular block within the ring fractures, (4) formation of a lake within the caldera, accumulation of volcanic rocks within the caldera through additional eruptions, and erosion of volcanic rocks from the caldera rim, (5) uplift and doming of the central block, with faulting of this resurgent dome and extrusion of lava from the faults, (6) volcanic eruptions through the ring fractures after doming and formation of lava domes in the moat that separates the resurgent dome from the rim of the caldera, and (7) erosion and hot-spring and fumarolic activity. The generalized map and schematic geologic section in figure 4 show features associated with this sequence. A detailed geologic map of the Jemez Mountains also was prepared by Smith and others (1970).

The ring-fracture zone along which the Valles Caldera floor collapsed is about $8-10 \mathrm{mi}$ in diameter (fig. 5). The resurgent dome as now exposed composes about one-fourth of the area of the caldera; its summit is Redondo Peak. A graben crosses the resurgent dome in a southwest-northeast direction and is aligned with the Jemez Fault Zone in the Cañon de San Diego. Much of the moat is occupied by rhyolite domes, which form a ring around the resurgent dome. The ages of the dated rhyolite domes in the northern part of the moat range from about 1.0 to $0.45 \mathrm{Ma}$; the youngest volcanic eruptions, which occurred in the southern part of the moat, were as recent as $0.13 \mathrm{Ma}$ (Doell and others, 1968; Gardner and others, 1986). The remainder of the moat forms the Valle San Antonio, Valle Toledo, and Valle Grande (fig. 6).

All rocks exposed in the Valles Caldera are volcanogenic (Smith and others, 1970). They are the Bandelier Tuff and caldera fill in the resurgent dome; Valles Rhyolite in the volcanic domes that occupy the moat; alluvial, lacustrine, and fan deposits of volcanicrock detritus in the remainder of the moat; and landslide deposits and volcanic rocks of several units below the rim of the caldera.

Approximately 40 intermediate to deep boreholes have been used to explore the subsurface geology of the Valles Caldera. Most have been drilled within and near the caldera since 1960 primarily to evaluate geothermal resources; they also include three core holes drilled for scientific research by the CSDP between 1984 and 1988. Because the principal geothermal reservoir is located under the central and western parts of the caldera, the geology of this part of the caldera has been investigated in greatest detail. Most exploratory holes were drilled as part of the Union Oil Company Baca project and are collectively referred to as the Baca wells (fig. 5). Nielson and Hulen (1984, table 1) summarized geologic logs of Baca holes and presented a detailed description of the subsurface geology of the central and western parts of the caldera; Wilt and Vonder Harr (1986) also presented a description of the central and western parts of the caldera based on geophysical and geological data.

The stratigraphy of the Valles Caldera, as interpreted from drill holes, is presented in table 1. Precambrian granitic rocks underlie the caldera at depth. Overlying the Precambrian granite rocks, in ascending order, are the Madera Limestone, the arkosic Abo Formation, and the arkosic Santa Fe Group/ Abiquiu Tuff. Volcanic units overlie these sedimentary rocks. The oldest is the Paliza Canyon Formation, which is composed of altered andesites and dacites. Overlying this formation in the eastern part of the caldera is the Tschicoma Formation, composed of dacite, rhyodacite, and quartz latite (Smith and others, 1970); in the western part of the caldera the formation is overlain by a sequence of tuffaceous rocks designated the "Lower Tuffs" by Nielson and Hulen (1984). The younger Bandelier Tuff, present throughout the Jemez Mountain area, overlies these units. It is greater than $6,000 \mathrm{ft}$ thick in some areas of the caldera, but is only locally greater than $1,000 \mathrm{ft}$ thick outside the caldera. The greater thickness within the caldera is attributed to simultaneous eruption of the tuff and collapse of the caldera (Dondanville, 1978, p. 157). 


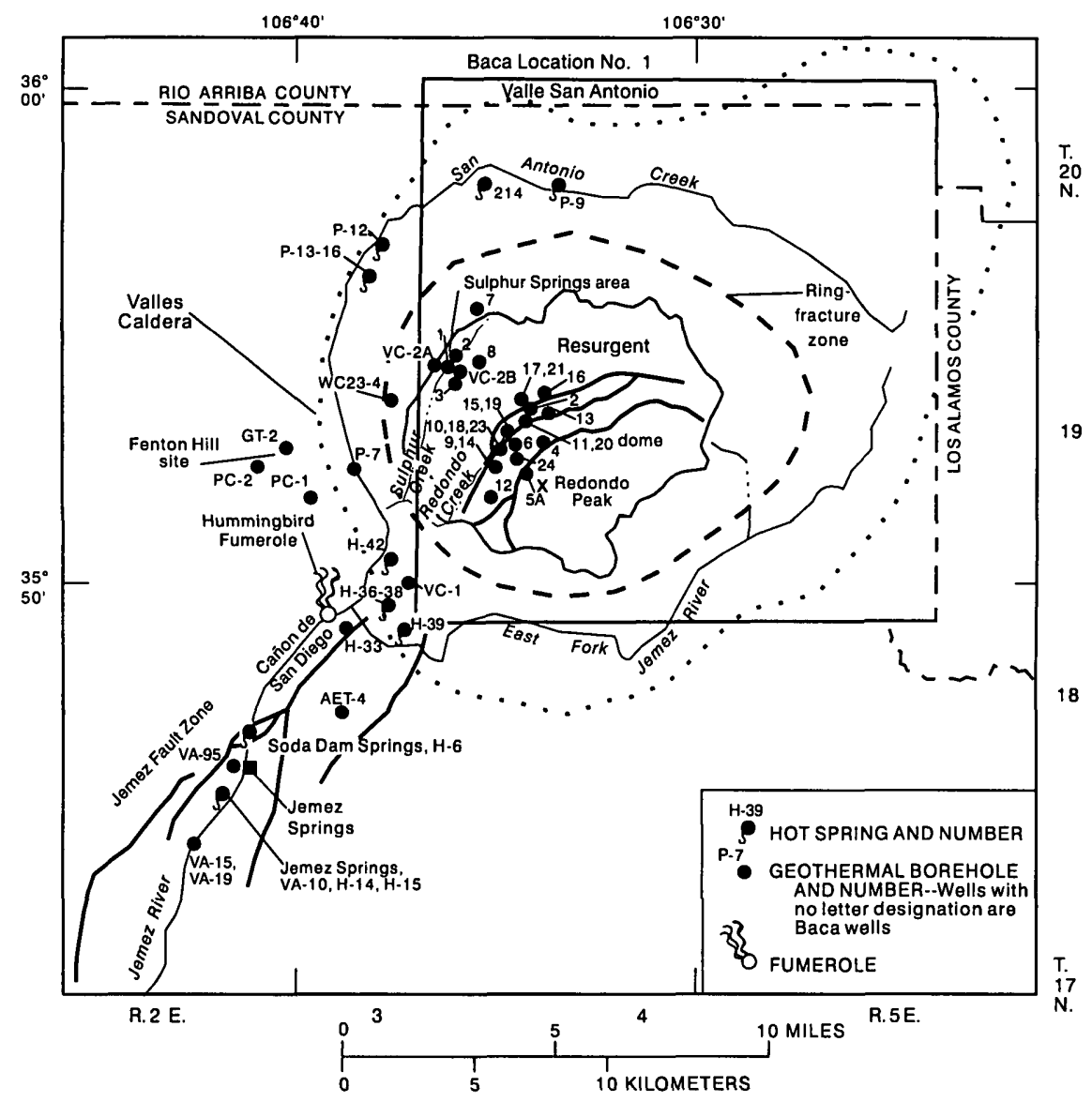

Figure 5.--Location of selected geothermal boreholes and hot springs in the Valles Caldera region (locations from Trainer, 1978; and Goff and others, 1992).

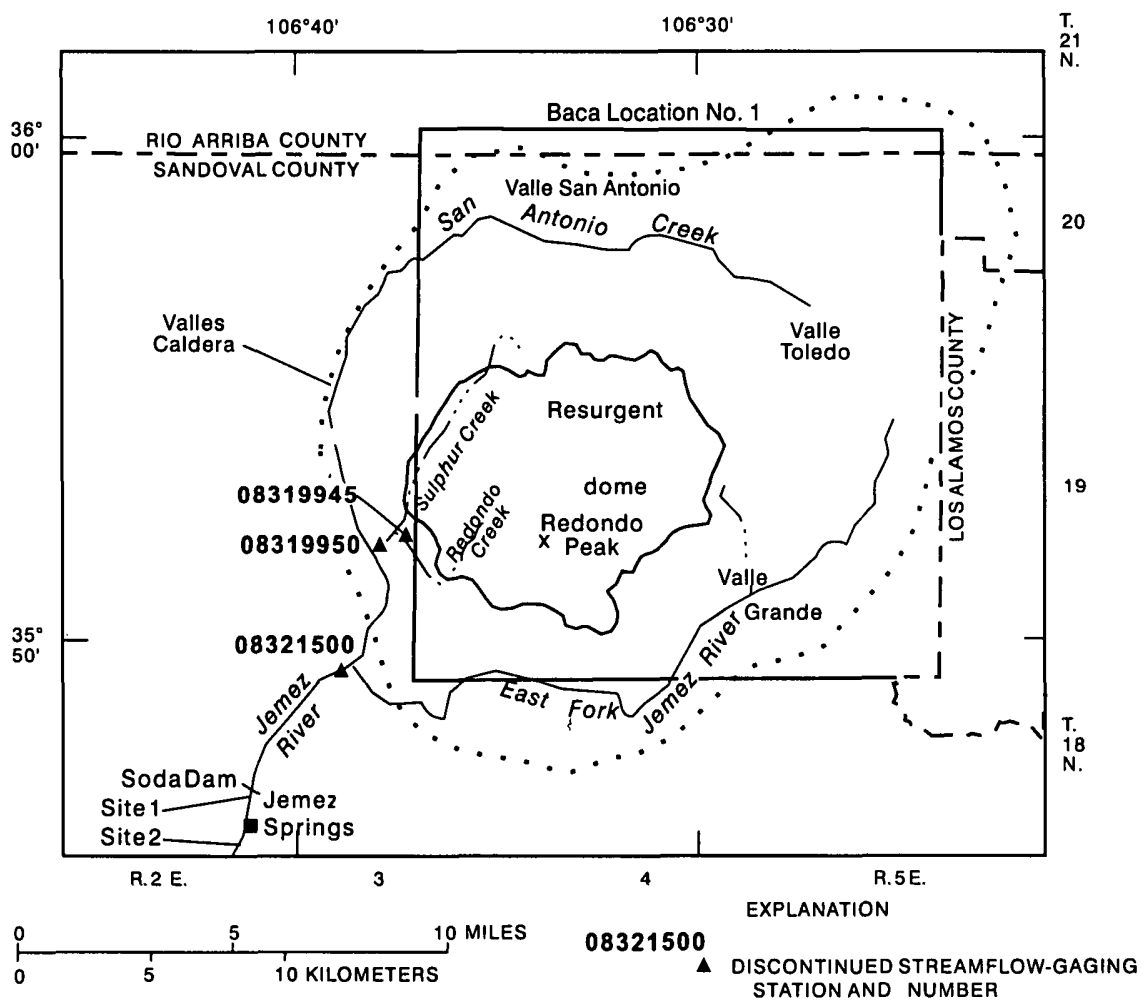

Figure 6.--Principal streams in the Valles Caldera region and location of discontinued U.S. Geological Survey streamflow-gaging stations. 
Quaternary Valles Rhyolite and caldera-fill deposits overlie the Bandelier Tuff. Alluvial, landslide, and lacustrine deposits form the youngest units in the caldera. A detailed description of rocks in the western half of the caldera is described in Nielson and Hulen (1984).

The subsurface "floor" of Valles Caldera is asymmetrical, and the caldera has been referred to as a "trapdoor" caldera (Nielson and Hulen, 1984). Depths to the Precambrian basement rocks range from about $2,500 \mathrm{ft}$ on the western edge, to about $10,000 \mathrm{ft}$ under Redondo Creek, to about $15,000 \mathrm{ft}$ on the east side (fig. 4B; Wilt and Vonder Haar, 1986). The asymmetry is consistent with the superposition of the caldera across the western edge of the older Rio Grande Rift (Heiken and others, 1986). Because deep holes have not been drilled in the eastern part of the caldera, what is known about the subsurface geology in this area is based primarily on geophysical data.

The major structural elements of Valles Caldera are ring faults that are associated with formation of the caldera and normal faults that form the Redondo Creek Graben, which trends northeastward across the center of the resurgent dome (fig. 4A). The concentrically arranged ring faults and associated fractures form a zone about 2 to $3 \mathrm{mi}$ wide that lies several miles within the topographic rim; for the most part, the zone is coincident with rhyolite domes that have extruded within the caldera. The Redondo Creek Graben that cuts across the resurgent dome is formed by numerous normal faults that align with the older Jemez Fault Zone to the southwest, which suggests that structures within the resurgent dome are controlled by older faults in the-Precambrian basement (Goff and Grigsby, 1982; Nielson and Hulen, 1984). Displacement along the graben is greater along the northwestern margin than along the southeastern margin. The high-angle faults of the graben and associated fractures serve as conduits for geothermal fluids in the caldera (Dondanville, 1978, p. 159).

\section{Hydrologic Setting}

The principal streams draining Valles Caldera are San Antonio, Redondo, and Sulphur Creeks and the East Fork Jemez River (fig. 6). San Antonio Creek and the East Fork Jemez River join just outside the topographic rim of the caldera to form the Jemez River. Both San Antonio Creek and the East Fork Jemez River appear to be gaining streams throughout the caldera.
The base flow of streams in the caldera is from shallow, nonthermal ground-water systems and also, in places, from thermal or mineral springs. The USGS operated streamflow-gaging stations on Redondo Creek (station 08319945) and Sulphur Creek (station 08319950) during water years 1982-85 and on the Jemez River directly below the confluence of the East Fork (station 08321500) periodically during water years 1951-90. Redondo Creek (12.1- $\mathrm{mi}^{2}$ drainage area) had a mean daily discharge of $3.15 \mathrm{ft}^{3} / \mathrm{s}$ for water years $1983-84$, and Sulphur Creek (38.0-mi ${ }^{2}$ drainage area) had a mean daily discharge of $4.17 \mathrm{ft}^{3} / \mathrm{s}$ for the same period. The Jemez River below East Fork (173- $\mathrm{mi}^{2}$ drainage area) had a mean daily discharge of $33.2 \mathrm{ft}^{3} / \mathrm{s}$ during 28 years of record (water years 1950, 1959-76, 1982-90).

Vuataz and Goff (1986) analyzed tritium data for three streams within and two streams outside the rim of Valles Caldera: San Antonio, Sulphur, and Redondo Creeks; East Fork Jemez River near its confluence with San Antonio Creek; and the Jemez River upstream from Soda Dam (fig. 6). Because these streams drain small areas, the stream water clearly exhibits local and seasonal variations in the tritium content of precipitation. The tritium content of the streams in 1982-83 varied between 6 and 39 tritium units (TU), which indicated that the average age of the stream water ranged from 0 to 5 years. The seasonal variations observed in the Valles Caldera streams were similar to seasonal variations observed in the tritium content of precipitation in Albuquerque (U.S. Geological Survey, Albuquerque, N. Mex., unpublished data).

Vuataz and Goff (1986, table 1) compiled and analyzed a considerable number of isotopic analyses for oxygen-18 $\left({ }^{18} \mathrm{O}\right)$ and deuterium $\left({ }^{2} \mathrm{H}\right.$ or $\left.\mathrm{D}\right)$ in water from the Jemez Mountains. From these data, they defined the following empirical relation, or meteoricwater line, for precipitation in the Valles Caldera area:

$$
\delta \mathrm{D}=8 \delta^{18} \mathrm{O}+12
$$

where $\delta \mathrm{D}$ is the deuterium content and $\delta^{18} \mathrm{O}$ is the oxygen-18 content of water expressed in permil relative to standard mean ocean water (SMOW), the normal reference standard. This relation is consistent with the location of the region relative to the ocean. Vuataz and Goff (1986) also calculated the relations between the altitude of ground-water recharge and the $\delta \mathrm{D}$ and $\delta^{18} \mathrm{O}$ content of the recharge water; the relations are the result of the pronounced gradient of 
the isotopic composition of precipitation with altitude. For Valles Caldera the relations are:

$$
E=-147.3(\delta D)-3786
$$

and

$$
E=-1030\left(\delta^{18} O\right)-3809
$$

where $E$ is the altitude, in feet, of ground-water recharge. Equations 1-3 were used to evaluate the source regions and circulation paths of ground water in the region, which is discussed in more detail in the following sections.

Several types of ground water-distinct in history, mode of occurrence, temperature, or geochemistry - have been identified in Valles Caldera and the Jemez Mountains. Trainer (1974) identified warm and cold water of shallow circulation, acid sulfate water, and geothermal reservoir fluid. Goff and Grigsby (1982) and Vuataz and Goff (1986) expanded the understanding of different water types in the Valles Caldera. Dondanville (1971), Trainer (1975), and Goff and others (1981) first discussed the mineral waters outside the caldera as mixtures derived in part from reservoir fluid.

\section{Nonthermal Ground Water}

Nonthermal ground water in Valles Caldera occurs in diverse, perched aquifers and in deeper valley-fill aquifers. Although the hydrologic relation between the nonthermal aquifers and the geothermal reservoir has not been fully established, nonthermal water is distinguished from its thermal counterpart by small concentrations of chloride and trace elements, such as boron (Vuataz and Goff, 1986); the dominant anion in nonthermal water is bicarbonate. The oxygen and hydrogen isotopic composition of nonthermal ground water indicates that it is of meteoric origin (Vuataz and Goff, 1986).

The near-surface, nonthermal ground water of Valles Caldera occurs in valley-fill deposits and volcanic rocks of the interior domes. Volcanic rocks in the caldera do not contain important aquifers, but in places springs issue from these rocks. Small ephemeral seeps and springs and spring-fed streams that drain the unconsolidated deposits below the slopes of the caldera rim, resurgent dome, and volcanic domes in the moat indicate that these deposits are partly saturated during spring and early summer. Perennial springs issue from fractured rock in the volcanic domes, particularly at the edges of large moat valleys, and from terrace deposits of alluvial deposits at the sides of large valleys. The porous rhyolite domes are important recharge areas for the volcanogenic sedimentary rocks that fill the caldera.

Volcanogenic sand and gravel of the intracaldera lake deposits form the most extensive nongeothermal aquifers in Valles Caldera and are found primarily in Valle Grande and Valle Toledo in the east and northeast areas of the caldera (fig. 6). Conover and others (1963) investigated ground-water conditions in the area in 1949 to determine water-supply potential. The following summary is based primarily on their report.

The maximum thickness of sand and gravel fill in Valle Grande is not known; the deepest hole drilled $(1,185 \mathrm{ft})$ did not reach the base of the valley fill. The maximum thickness of unconsolidated deposits in Valle Toledo is about $450 \mathrm{ft}$. The valley fill consists chiefly of volcanogenic sand and gravel, with intercalated beds of clay that were deposited in the caldera lake. The central part of each valley is underlain by one or more extensive clay beds; the clay beds are less extensive near the valley walls than in central parts of the valley. Ground water is confined beneath the clay over large areas, and where confined, the potentiometric surface is commonly above land surface. The overlying confining clay is as much as 295 $\mathrm{ft}$ thick in Valle Grande and about $80 \mathrm{ft}$ thick in Valle Toledo. Ground water generally is unconfined outside the margins of the clay.

In Valle Grande and Valle Toledo recharge occurs by infiltration of rain and snowmelt on some of the mountain slopes and on alluvial fans and benches that border the valleys. Springs issuing from the rhyolite domes near the margins of the valleys and springs that flow from the unconsolidated deposits at the valley margins provide recharge to the valley-fill aquifers.

Natural discharge of nonthermal ground water from Valles Caldera takes several paths, not all of which are fully understood. Some water obviously discharges through springs, especially from the higher, less extensive aquifers. Water from the more extensive principal aquifers in the valley fill also discharges as spring flow and seepage to the principal streams, as evidenced by downstream gain in discharge of valley streams (Conover and others, 1963). Tritium analyses of nonthermal springs in the caldera indicate that most springs issue water between 20 and 75 years old (Vuataz and Goff, 1986). Tritium analyses of water from San Antonio Creek and East Fork Jemez River 
indicate that during some seasons these streams may contain more than 50 percent ground water of this age.

Some deeper discharge from the valley-fill aquifers recharges the underlying geothermal reservoir by slow leakage through relatively impermeable rocks and along fractures and faults (Faust and others, 1984; Vuataz and Goff, 1986). Purtymun and Johansen (1974) proposed ground-water discharge from Valles Caldera as the major source of recharge to the main aquifer under the Los Alamos area, which means that substantial ground-water discharge from the caldera must pass under the caldera rim to the east. However, several lines of evidence indicate that ground-water discharge from the caldera cannot be a substantial source of recharge to the main aquifer under Los Alamos (Fraser Goff, Los Alamos National Laboratory, written commun., 1993). First, if water in the main aquifer were recharged by ground water from the caldera, the stable isotopic content of ground water in the two areas should be similar. However, the deuterium and ${ }^{18} \mathrm{O}$ content of water from cold springs and geothermal wells in the caldera is significantly different from that of water from wells and springs in the main aquifer near Los Alamos. Second, two major structural barriers to ground-water flow lie between Valles Caldera and the Pajarito Plateau-the ringfracture zone and collapse faults of the caldera depression and the Pajarito Fault Zone (fig. 4A).

According to Goff, faults of this magnitude impede the flow of ground water in directions normal to the fault plane because of the presence of fault gouge and clays, which create a relatively impermeable barrier within the fault zone.

The principal aquifer and stream in each major valley form a single hydraulic system according to Conover and others (1963). Their study showed that properly constructed wells in the valley fill can each yield more than 1,000 gallons per minute (gal $/ \mathrm{min}$ ). They estimated from aquifer tests that the transmissivity of the valley-fill aquifer is at least 3,300 feet squared per day $\left(\mathrm{ft}^{2} / \mathrm{d}\right)$; the storage coefficient was not determined. The specific capacity of the pumped well used in the Valle Grande test was about 10 gallons per minute per foot (gal/min/ft) of drawdown. Aquifer tests in Valle Toledo showed transmissivity to be about $6,700 \mathrm{ft}^{2} / \mathrm{d}$ and the storage coefficient to be about 0.005 . The specific capacity of the pumped well used in the Valle Toledo test was about $50 \mathrm{gal} / \mathrm{min} / \mathrm{ft}$ of drawdown. Conover and others (1963) concluded that a considerable supply of ground water could be developed because of large volumes of water stored in the valley fill. However, by assuming as they did that all ground-water discharge from the perched aquifers was in the form of spring flow and seepage to streams, the amount of water perennially available to wells as recharge would equal the base flow of streams in the valleys under nondeveloped conditions. From streamflow measured in 1948 and 1949, Conover and others (1963, p. 33-34) estimated these amounts to be about 750 million gallons (gal) or 2,200 acre-feet per year (acre-ft/yr) in Valle Grande and about 540 million gal or 1,600 acre-ft/yr in Valle Toledo.

\section{Surface and Near-Surface Geothermal Features}

The geothermal system underlying the Jemez Mountains, primarily in the center and western half of Valles Caldera, manifests itself in several forms at the surface, including young rhyolitic volcanic rocks, thermal waters, hydrothermally altered rocks, and elevated heat flow. These surface features guided early exploration for geothermal resources (Dondanville, 1978), which began in the Sulphur Springs area (Baca wells 1, 2, and 3; fig. 5). Thermal waters that discharging at the surface in the Valles Caldera are grouped into two types on the basis of their geochemistry and geohydrology: (1) thermal meteoric waters and (2) acid sulfate waters (Trainer, 1974; Goff and Grigsby, 1982; Vuataz and Goff, 1986).

\section{Thermal Meteoric Water}

Thermal meteoric water discharges from fractures in rhyolite and from contacts of rhyolite and underlying units in the ring-fracture zone of the western and southwestern parts of the caldera; several shallow wells in the southwestern section of the moat also have penetrated this type of water, for example well P-7 (fig. 5). Selected physical data for hot springs and a geothermal well in the Valles Caldera are summarized in table 2. Temperatures of thermal meteoric water range from 16.4 to $40.6{ }^{\circ} \mathrm{C}$ (table 2) compared with about 10 to $15^{\circ} \mathrm{C}$ for other shallow ground water in the region (Vuataz and Goff, 1986, table 1). Chemically and isotopically, thermal meteoric water resembles cold ground water that has been conductively heated (Vuataz and Goff, 1986, p. 1840). More concentrated thermal water from the geothermal reservoir has been penetrated in deep drill holes in the southwestern part of the caldera and is discussed later in the report. 


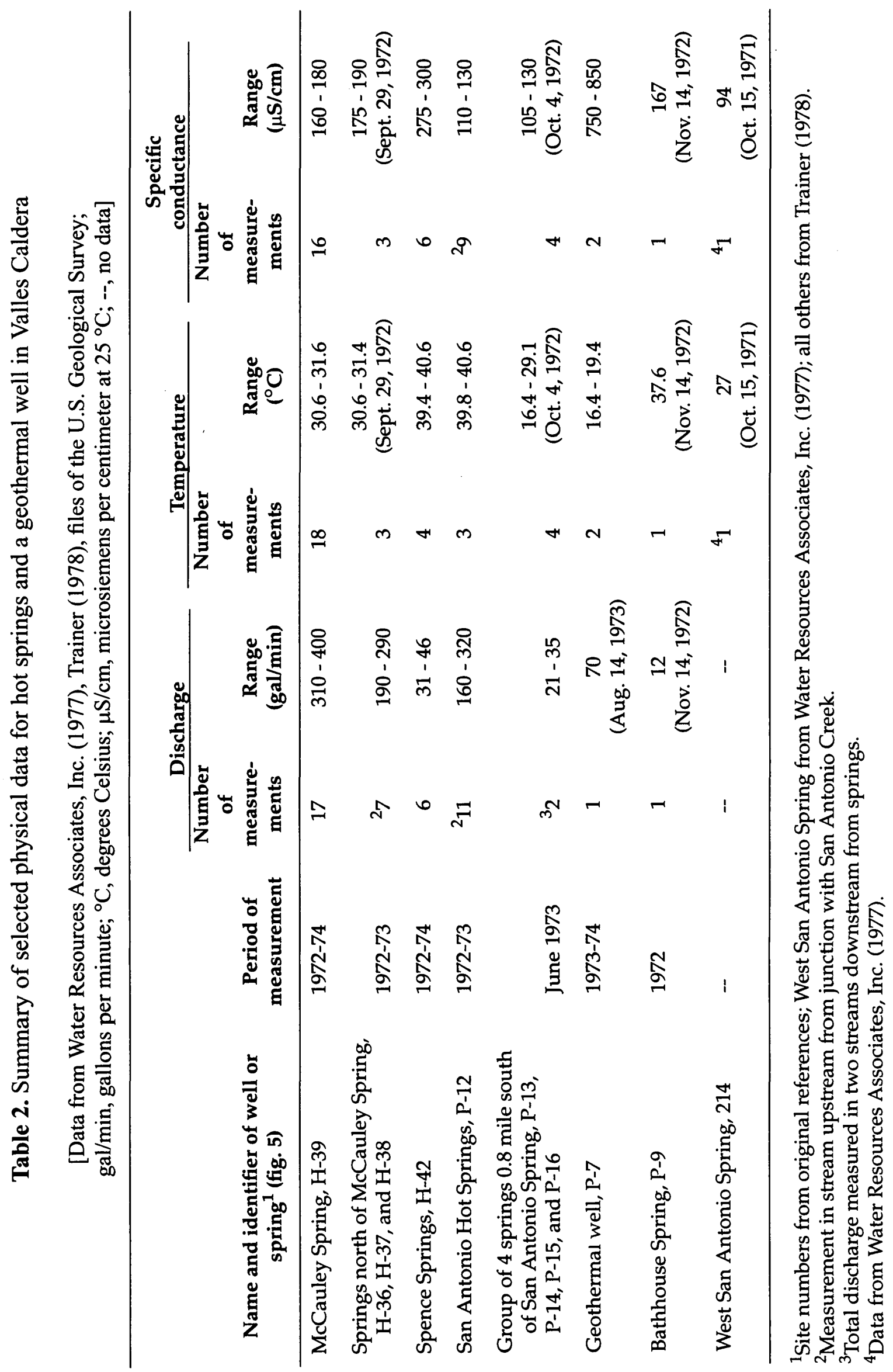


The hot springs and geothermal wells represent two geohydrologic settings: one in which the groundwater flow field approaches the ideal assumed for flow through relatively homogeneous material and one in which flow is confined by an impervious boundary at the base of the aquifer. The first geohydrologic setting is exemplified by the Bathhouse Spring (P-9, fig. 5), which yields water transmitted by a fracture in rhyolite overlain by alluvium (Summers, 1976, p. 31). The flow path is visualized as a broad arc, convex downward, from a higher recharge area to the discharge point near the stream. Flow to geothermal wells in this area is believed to be similar except that the wells intercept the flow path beneath the surface and thus "short circuit" the latter part of the normal flow path. The second geohydrologic setting is exemplified by springs $\mathrm{H}-39$ and P-12 (fig. 5). Each spring is at or near the contact of volcanic rock and underlying Abo Formation and is interpreted as a contact spring that drains a perched aquifer. The ultimate control on locations of the springs is probably the topographic form of the unconformity between the Abo Formation and overlying volcanic rock, with the springs draining valleys on the Abo surface.

In both settings described above, geochemical data suggest that the thermal water is composed primarily of ground water that circulates in the upper $1,500 \mathrm{ft}$ of the caldera moat and is heated by the high upward heat flux in the area; further, the thermal water does not appear to be composed of hydrothermal fluids or a mixed water containing such fluids (Goff and Grigsby, 1982; Vuataz and Goff, 1986). Chemical analyses of thermal meteoric ground water from the Valles Caldera are presented in table 3; additional chemical data are listed in Vuataz and Goff (1986, table 1). The thermal meteoric ground water of the caldera is a dilute sodium calcium bicarbonate water and is chemically and isotopically similar to the nonthermal ground water of the caldera. However, the thermal meteoric water generally has larger $\mathrm{SiO}_{2}$ concentrations than its nonthermal counterpart. The composition of thermal water differs from that of water in the underlying Abo Formation and Madera Limestone, indicating that the thermal water is not likely to have flowed through these rocks for any distance. Rather, the chemical composition of the thermal water indicates that it has been in contact with volcanic rock, largely or exclusively, since entering the ground.
The deuterium and $\delta^{18} \mathrm{O}$ content of selected samples of thermal meteoric and other types of ground water from and near the caldera is listed in table 4; locations of sites listed in table 4 are shown in figures 5 and 7. Vuataz and Goff (1986, table 1) presented additional isotopic analyses of thermal meteoric water. A plot of $\delta \mathrm{D}$ and $\delta^{18} \mathrm{O}$ values of selected thermal meteoric water samples is shown in figure 8; other water types from the Jemez Mountains also are shown, as is the meteoric-water line for the Jemez Mountains region developed by Vuataz and Goff (1986, fig. 5). The isotopic compositions of the thermal meteoric ground water, which plot close to the meteoric-water line, indicate that this water is derived from local precipitation and that its isotopic composition has not been significantly changed by water-rock interaction or boiling.

The tritium content of Bathhouse Spring, San Antonio Hot Spring, Spence Spring, and McCauley Spring (P-9, P-12, H-42, and H-39, respectively, in fig. 5) was determined by Trainer (1978, p. 127) and Vuataz and Goff (1986, table 1). Water samples were collected from the springs in March of 1973, 1982, and 1983. In 1973 and 1983, the tritium content of the four springs was less than $1 \mathrm{TU}$, which indicates that the water probably entered the ground more than 50 years prior to discharging at the springs. In March 1982, however, the tritium content of the springs was between 2 and $8 \mathrm{TU}$, and the mineral content of the water was slightly smaller than that of samples collected in 1983. The tritium data for 1982 indicate that some post-1953 water contributes to the flow of these thermal springs. When considered collectively, the isotope and chemical data support the idea that the thermal water issuing from the springs is composed primarily of ground water that circulates in the upper $1,500 \mathrm{ft}$ of the caldera moat and is heated by the high conductive heat flux in that area (Vuataz and Goff, 1986).

\section{Acid Sulfate Water}

Acid sulfate water is characterized by low $\mathrm{pH}$ and large concentrations of sulfate and issues from fractures and faults on the western slope of the resurgent dome. The Sulphur Springs area (figs. 5 and 9), where several major faults and fractures intersect, contains the largest concentration of springs that issue acid sulfate water. The area is also the hottest and most active zone of surface thermal manifestations in the caldera and contains thermal and nonthermal springs, 

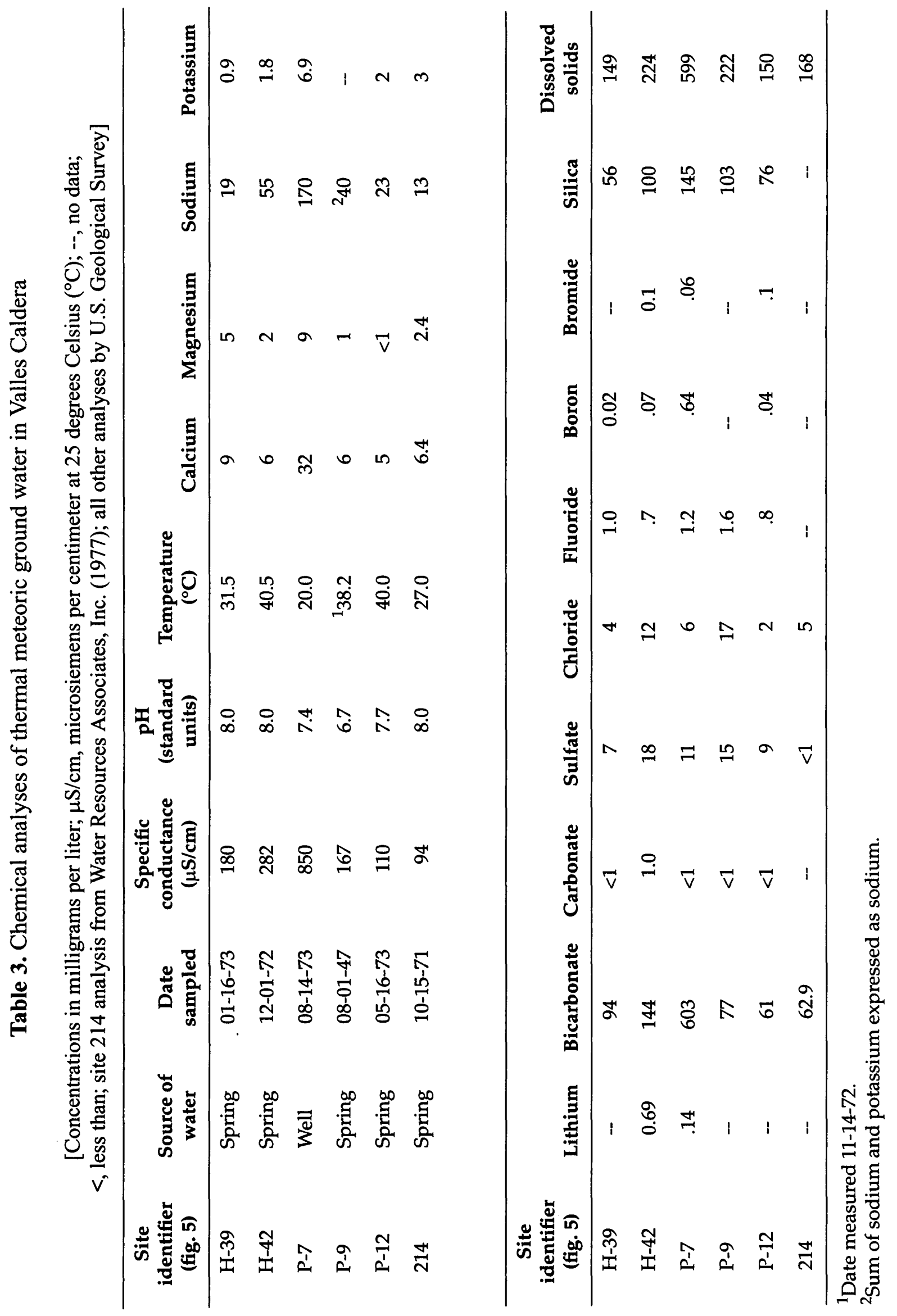
Table 4. Deuterium and oxygen-18 isotope data for wells, springs, and streams in the Jemez Mountains region

$\left[\%{ }_{00}\right.$, permil; ${ }^{\circ} \mathrm{C}$, degrees Celsius; $\mathrm{xx}$, day of month not reported; --, no data or not applicable; LANL, Los Alamos National Laboratory]

\begin{tabular}{|c|c|c|c|c|c|c|c|}
\hline $\begin{array}{c}\text { Site } \\
\text { identifier } \\
\text { (figs. } 5 \\
\text { and 7) }\end{array}$ & Sample source & Date & $\begin{array}{c}\delta D \\
(\% \%)\end{array}$ & $\begin{array}{l}\delta^{18} O \\
(\% / 00)\end{array}$ & $\begin{array}{l}\text { Tem- } \\
\text { per- } \\
\text { ature } \\
\left({ }^{\circ} \mathrm{C}\right)\end{array}$ & $\begin{array}{l}\text { Altitude of } \\
\text { land surface } \\
\text { (feet above } \\
\text { sea level) }\end{array}$ & $\begin{array}{l}\text { Refer- } \\
\text { ence }^{1}\end{array}$ \\
\hline \multicolumn{8}{|c|}{ Los Alamos and Pajarito area } \\
\hline LA-1 & Gallery Spring & $\begin{array}{l}07-24-76 \\
08-07-78\end{array}$ & $\begin{array}{l}-88.7 \\
-84.3\end{array}$ & $\begin{array}{l}-12.00 \\
-12.20\end{array}$ & $\ddot{11}$ & 8,000 & $\begin{array}{l}A \\
D, F\end{array}$ \\
\hline LA-4 & Sacred Spring & $08-07-78$ & -81.8 & -11.80 & 14 & 5,640 & $\mathrm{D}, \mathrm{F}$ \\
\hline LA-5 & Basalt Spring & $08-17-78$ & -76.5 & -10.85 & 15 & 6,200 & $\mathrm{D}, \mathrm{F}$ \\
\hline LA-19 & White Rock Canyon Spring & $09-07-76$ & -76.8 & -11.00 & 19 & 5,400 & $\mathrm{D}, \mathrm{F}$ \\
\hline L-1B & Well L-1B, LANL & $\begin{array}{l}07-24-76 \\
09-x x-78\end{array}$ & $\begin{array}{l}-107.4 \\
-103.4\end{array}$ & $\begin{array}{l}-14.30 \\
-14.30\end{array}$ & 30 & $\begin{array}{l}-- \\
-\end{array}$ & $\begin{array}{l}\text { A } \\
D, F\end{array}$ \\
\hline L-6 & Well L-6, LANL & $09-x x-78$ & -94.7 & -13.45 & 27 & -- & $\mathrm{D}, \mathrm{F}$ \\
\hline LG-1 & Well G-1, LANL & $09-x x-78$ & -81.0 & -11.65 & 29 & -- & $\mathrm{D}, \mathrm{F}$ \\
\hline LG-1A & Well G-1A, LANL & $09-x x-78$ & -82.5 & -11.80 & 28 & -- & $\mathrm{D}, \mathrm{F}$ \\
\hline LG-2 & Well G-2, LANL & $09-x x-78$ & -83.1 & -11.95 & 30 & -- & $\mathrm{D}, \mathrm{F}$ \\
\hline LG-4 & Well G-4, LANL & $09-x x-78$ & -76.3 & -11.10 & 26 & -- & $\mathrm{D}, \mathrm{F}$ \\
\hline LG-6 & Well G-6, LANL & $09-x x-78$ & -76.0 & -11.25 & 31 & -- & $\mathrm{D}, \mathrm{F}$ \\
\hline $\mathrm{T}-2$ & Well T-2 & $08-x x-78$ & -73.5 & -10.60 & 11 & -- & F \\
\hline $\mathrm{T}-3$ & Well T-3 & $08-x x-78$ & -73.8 & -10.65 & 13 & -- & $\mathrm{F}$ \\
\hline PM-1 & Well PM-1, LANL & $\begin{array}{l}07-24-76 \\
09-x x-78\end{array}$ & $\begin{array}{l}-76.2 \\
-74.1\end{array}$ & $\begin{array}{l}-10.70 \\
-10.95\end{array}$ & -- & $\begin{array}{l}- \\
--\end{array}$ & $\begin{array}{l}A \\
D, F\end{array}$ \\
\hline PM-2 & Well PM-2, LANL & $09-x x-78$ & -77.5 & -11.40 & 24 & -- & $\mathrm{D}, \mathrm{F}$ \\
\hline \multicolumn{8}{|c|}{ Sulphur Springs area } \\
\hline P-2 & Men's Bathhouse Spring & $\begin{array}{l}11-30-72 \\
01-x x-79 \\
08-x x-81\end{array}$ & $\begin{array}{l}-47.7 \\
-50.2 \\
-47.1\end{array}$ & $\begin{array}{l}-2.12 \\
-3.25 \\
-3.65\end{array}$ & $\begin{array}{l}78 \\
82\end{array}$ & 8,500 & $\begin{array}{l}\text { A } \\
\text { F } \\
\text { F }\end{array}$ \\
\hline VG-21 & Sulphur Creek & $08-x x-81$ & -72.9 & -9.75 & 16 & & F \\
\hline
\end{tabular}


Table 4. Deuterium and oxygen-18 isotope data for wells, springs, and streams in the Jemez Mountains region--Continued

\begin{tabular}{|c|c|c|c|c|c|c|c|}
\hline $\begin{array}{c}\text { Site } \\
\text { identifier } \\
\text { (figs. } 5 \\
\text { and 7) }\end{array}$ & Sample source & Date & $\begin{array}{c}\delta \mathrm{D} \\
(\%)\end{array}$ & $\begin{array}{l}\delta^{18} O \\
(\%)\end{array}$ & $\begin{array}{l}\text { Tem- } \\
\text { per- } \\
\text { ature } \\
\left({ }^{\circ} \mathrm{C}\right)\end{array}$ & $\begin{array}{l}\text { Altitude of } \\
\text { land surface } \\
\text { (feet above } \\
\text { sea level) }\end{array}$ & $\begin{array}{l}\text { Refer- }^{1} \\
\text { ence }^{1}\end{array}$ \\
\hline \multicolumn{8}{|c|}{ Ring-fracture zone } \\
\hline $\mathrm{H}-39$ & McCauley Spring & $\begin{array}{l}12-13-74 \\
07-26-76 \\
03-x x-82\end{array}$ & $\begin{array}{l}-91.0 \\
-90.6 \\
-89.1\end{array}$ & $\begin{array}{l}-12.44 \\
-12.70 \\
-12.45\end{array}$ & $\begin{array}{c}-- \\
-- \\
32\end{array}$ & 7,350 & $\begin{array}{l}\text { B } \\
\text { A } \\
\text { F }\end{array}$ \\
\hline $\mathrm{H}-42$ & Spence Spring & $\begin{array}{l}12-01-72 \\
07-24-76 \\
03-x x-82\end{array}$ & $\begin{array}{l}-86.8 \\
-88.4 \\
-86.5\end{array}$ & $\begin{array}{l}-11.89 \\
-12.05 \\
-12.25\end{array}$ & $\begin{array}{c}-- \\
-- \\
42\end{array}$ & 7,340 & $\begin{array}{l}B \\
A \\
F\end{array}$ \\
\hline P-7 & $\begin{array}{l}\text { Thermal well near San Antonio } \\
\text { Creek }\end{array}$ & $\begin{array}{l}12-13-74 \\
07-24-76\end{array}$ & $\begin{array}{l}-92.7 \\
-93.5\end{array}$ & $\begin{array}{l}-12.99 \\
-12.70\end{array}$ & - & -- & $\begin{array}{l}\mathrm{B} \\
\mathrm{A}\end{array}$ \\
\hline P-9 & Bathhouse Spring & $\begin{array}{l}02-x x-79 \\
03-x x-82\end{array}$ & $\begin{array}{l}-86.4 \\
-85.0\end{array}$ & $\begin{array}{r}-12.40 \\
-11.80\end{array}$ & $\begin{array}{l}38 \\
37\end{array}$ & 8,430 & $\begin{array}{l}F \\
F\end{array}$ \\
\hline P-11 & $\begin{array}{l}\text { Cold Spring near San Antonio } \\
\text { Hot Spring }\end{array}$ & $07-20-76$ & -93.2 & -12.70 & - & 8,280 & $\mathrm{C}$ \\
\hline P-12 & San Antonio Hot Spring & $\begin{array}{l}07-20-76 \\
03-x x-82\end{array}$ & $\begin{array}{l}-93.6 \\
-91.6\end{array}$ & $\begin{array}{l}-13.10 \\
-12.70\end{array}$ & 41 & 8,350 & $\begin{array}{l}\text { A } \\
\text { F }\end{array}$ \\
\hline VG-34 & Battleship Seep & $04-x x-80$ & -92.7 & -12.80 & 11 & 6,790 & $\mathrm{~F}$ \\
\hline VG-39 & Valle Grande Spring & $03-x x-82$ & -85.1 & -12.50 & 14 & 8,630 & $\mathrm{~F}$ \\
\hline SAC & San Antonio Creek & $\begin{array}{l}02-x x-79 \\
03-x x-82\end{array}$ & $\begin{array}{l}-92.9 \\
-90.5\end{array}$ & $\begin{array}{l}-12.85 \\
-12.85\end{array}$ & $\begin{array}{l}2 \\
3\end{array}$ & 8,430 & $\begin{array}{l}\mathrm{F} \\
\mathrm{F}\end{array}$ \\
\hline EF & East Fork Jemez River & $03-x x-82$ & -88.0 & -12.40 & 4 & 6,790 & F \\
\hline \multicolumn{8}{|c|}{ Soda Dam and Jemez Springs area } \\
\hline $\mathrm{H}-6$ & Soda Dam Spring & $\begin{array}{l}12-01-79 \\
01-x x-83\end{array}$ & $\begin{array}{l}-84.8 \\
-84.0\end{array}$ & $\begin{array}{l}-10.40 \\
-10.35\end{array}$ & 47 & 6,330 & $\begin{array}{l}\text { B } \\
\text { F }\end{array}$ \\
\hline $\mathrm{H}-17$ & Abandoned well, Jemez Springs & $05-30-74$ & -85.2 & -10.52 & - & & B \\
\hline VA-5 & Grotto Spring, Soda Dam & $07-x x-78$ & -84.6 & -10.65 & 38 & 6,330 & $\mathrm{~F}$ \\
\hline VA-10 & Main Spring, Jemez Springs & $\begin{array}{l}01-04-79 \\
01-19-79\end{array}$ & $\begin{array}{l}-82.3 \\
-81.4\end{array}$ & $\begin{array}{l}-10.6 \\
-10.4\end{array}$ & $\begin{array}{l}55 \\
36\end{array}$ & 6,200 & $\begin{array}{l}\mathrm{E} \\
\mathrm{E}\end{array}$ \\
\hline VA-15 & Well at Jemez Springs, at 500 feet & $01-19-79$ & -85.9 & -11.8 & 61 & 6,200 & $\mathrm{E}$ \\
\hline
\end{tabular}


Table 4. Deuterium and oxygen-18 isotope data for wells, springs, and streams in the Jemez Mountains region--Concluded

\begin{tabular}{|c|c|c|c|c|c|c|c|}
\hline $\begin{array}{c}\text { Site } \\
\text { identifier } \\
\text { (figs. } 5 \\
\text { and 7) }\end{array}$ & Sample source & Date & $\begin{array}{c}\delta \mathrm{D} \\
(\% / 00)\end{array}$ & $\begin{array}{l}\delta^{18} O \\
(\% / 00)\end{array}$ & $\begin{array}{l}\text { Tem- } \\
\text { per- } \\
\text { ature } \\
\left({ }^{\circ} \mathrm{C}\right)\end{array}$ & $\begin{array}{l}\text { Altitude of } \\
\text { land surface } \\
\text { (feet above } \\
\text { sea level) }\end{array}$ & $\begin{array}{l}\text { Refer- } \\
\text { ence }^{1}\end{array}$ \\
\hline VA-19 & Well at Jemez Springs, at 80 feet & 01-19-79 & -84.0 & -11.3 & 68 & 6,200 & $\mathrm{E}$ \\
\hline \multicolumn{8}{|c|}{ Redondo Creek area } \\
\hline $\mathrm{RC}$ & Redondo Creek & $05-x x-83$ & -88.7 & -12.50 & 4 & 8,010 & $\mathrm{~F}$ \\
\hline 4 & Baca 4 well & $06-x x-82$ & -88.3 & -9.96 & 294 & -- & $\mathrm{F}$ \\
\hline 13 & Baca 13 well & $06-x x-82$ & -86.3 & -9.96 & 278 & -- & $\mathrm{F}$ \\
\hline 15 & Baca 15 well & $07-x x-82$ & -83.9 & -8.61 & 268 & -- & $\mathrm{F}$ \\
\hline 19 & Baca 19 well & $10-x x-82$ & -83.1 & -8.41 & 223 & -- & F \\
\hline 24 & Baca 24 well & $06-x x-82$ & -81.8 & -8.43 & 259 & -- & $\mathrm{F}$ \\
\hline \multicolumn{8}{|c|}{ Other areas, Jemez Mountains } \\
\hline $\mathrm{H}-2$ & Spring, Agua Durme & $12-13-74$ & -80.0 & -12.05 & -- & 7,390 & B \\
\hline \multirow[t]{2}{*}{ N-4 } & Well GT-2, Fenton Hill & $04-23-74$ & -78.9 & -8.12 & -- & -- & B \\
\hline & & $11-x x-80$ & -82.6 & -11.05 & 160 & -- & $\mathrm{F}$ \\
\hline $\mathrm{N}-10$ & Spring, Calaveras Canyon & $12-07-72$ & -96.5 & -13.14 & -- & 8,155 & B \\
\hline VG-35 & Sino Spring & $03-x x-82$ & -87.2 & -11.90 & 17 & 7,550 & $\mathrm{~F}$ \\
\hline VG-38 & Indian Valley well & $10-x x-79$ & -91.1 & -12.75 & 18 & -- & F \\
\hline \multirow[t]{2}{*}{ VG-40 } & Las Conchas Spring & $08-x x-79$ & -78.2 & -11.40 & 15 & 9,090 & $\mathrm{~F}$ \\
\hline & & $05-x x-83$ & -79.3 & -11.65 & 3 & & \\
\hline VG-41 & Unnamed cold spring & $08-x x-79$ & -98.2 & -13.75 & 10 & 8,170 & F \\
\hline
\end{tabular}

${ }^{1}$ References:

A U.S. Geological Survey data files.

B Trainer, 1978, p. 130.

C Trainer and Lyford, 1979, p. 300.

D Goff and Sayer, 1980, p. 6.

E Goff and others, 1981, table 2.

F Vuataz and Goff, 1986, table 1.

${ }^{2}$ Recalculated isotope values before flashing. 


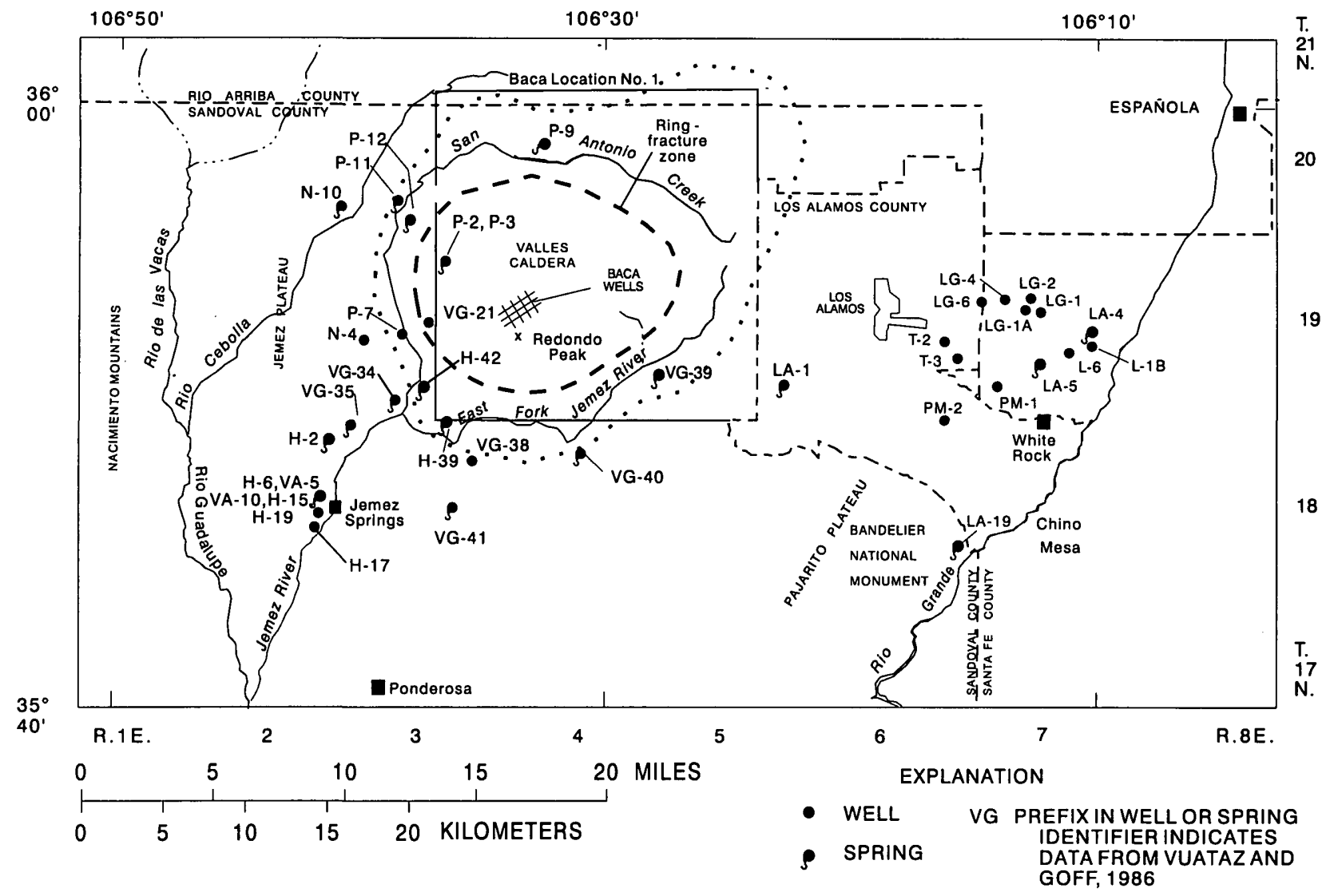

Figure 7.--Location of selected sampling sites for deuterium and oxygen-18 data listed in table 4.

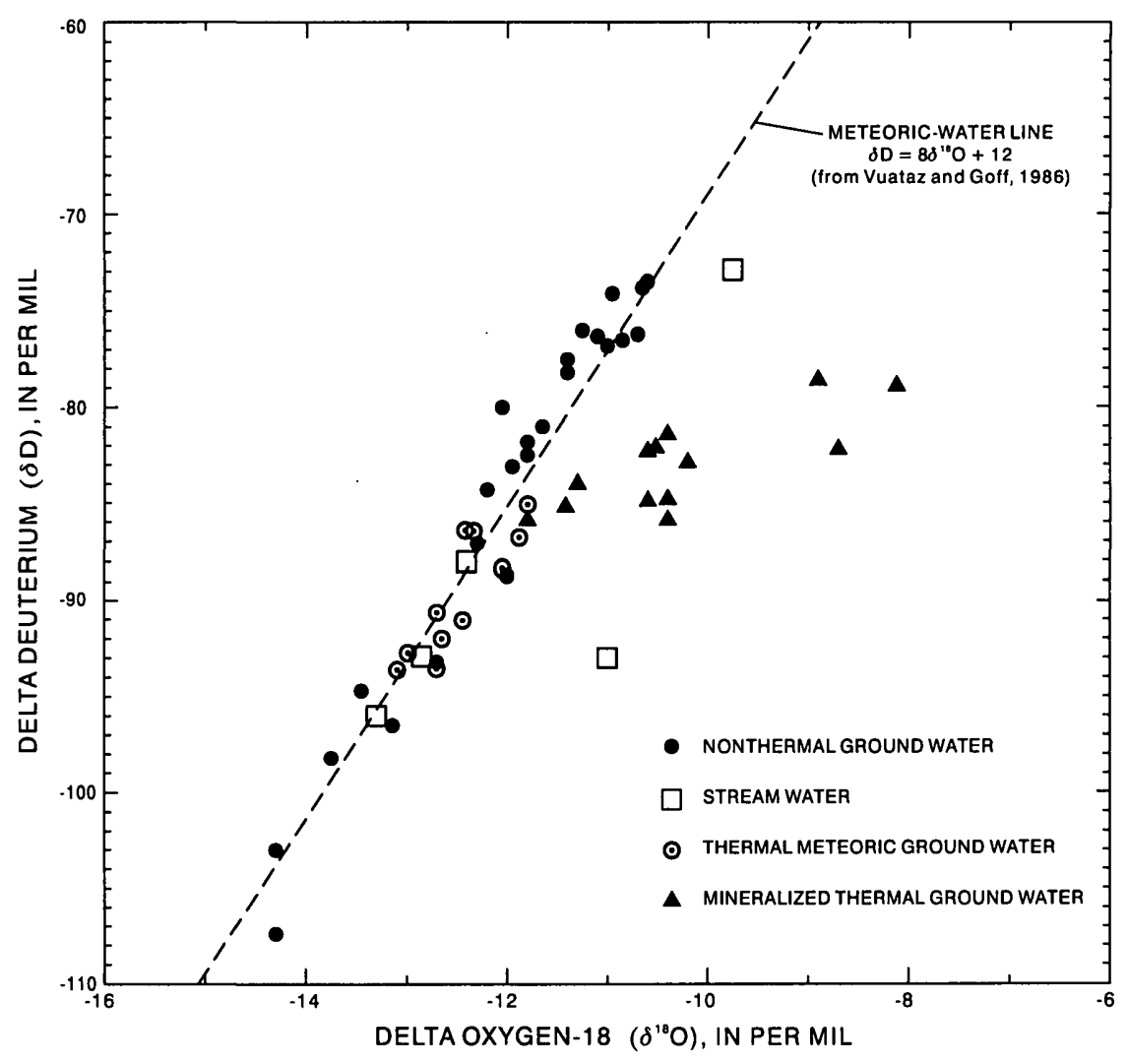

Figure 8.--Deuterium and oxygen-18 data for selected waters in the Jemez Mountains region. 


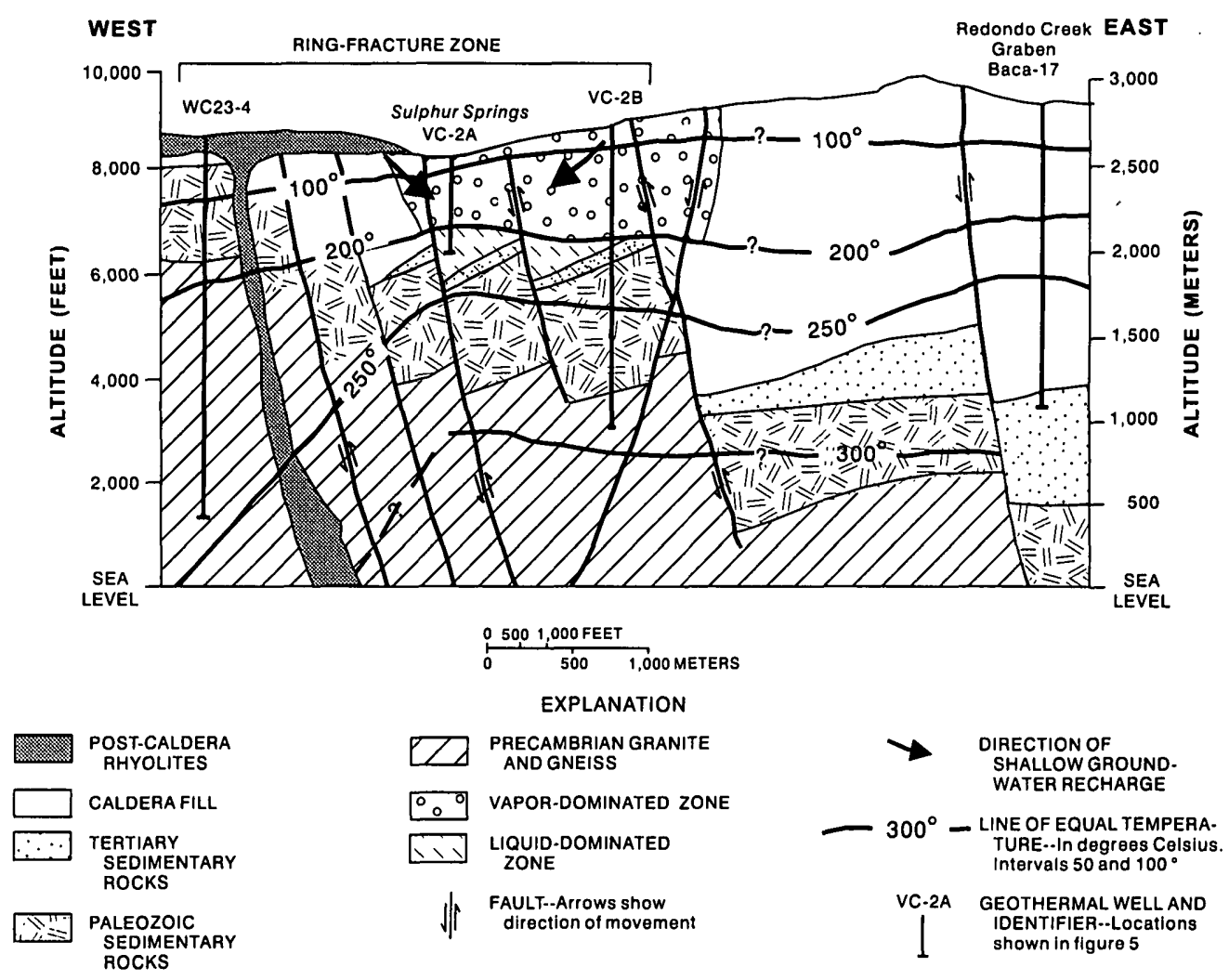

Figure 9.--Generalized section of the Sulphur Springs area, Valles Caldera

(modified from Goff and others, 1992, fig. 7, and published with

permission).

mud pots, fumaroles, and sublime sulfur (Goff and others, 1985). Hydrothermal alteration is prominent throughout the area and is most intense along fault traces. Gases also discharge in many other locations in the western part of the caldera as evidenced by perceptible levels of $\mathrm{H}_{2} \mathrm{~S}$ in the air and by the rise of bubbles through pooled surface water, particularly in the canyon of Redondo Creek (Union Oil Company of California and Public Service Company of New Mexico, 1978), but gases do not discharge to the extent that they do at Sulphur Springs. The geology, water and gas chemistry, and hydrothermal alteration of the Sulphur Springs area are discussed in detail in Goff and Grigsby (1982), Goff and others (1985), Charles and others (1986), and Vuataz and Goff (1986); the following discussion draws from those investigations.

The Sulphur Springs thermal features are manifestations of an underlying vapor-dominated zone of the geothermal reservoir (the only surface expression in the caldera of the reservoir) derived by the boiling of a deeper liquid-dominated flow system that does not reach the surface (Dondanville, 1978, p.
158; Goff and others, 1992). Water vapor, $\mathrm{H}_{2} \mathrm{~S}$, and $\mathrm{CO}_{2}$ are released from the underlying boiling liquid. As the gases reach the surface, the $\mathrm{H}_{2} \mathrm{~S}$ is oxidized to form $\mathrm{SO}_{4}$, which mixes with the condensing water vapor to form an acid condensate, which mixes with shallow ground water. Gaseous springs around the periphery of Sulphur Springs discharge what has been termed carbonated meteoric water (Goff and Grigsby, 1982). A generalized section of the Sulphur Springs area is presented in figure 9. The deeper geothermal system beneath the Sulphur Springs area is discussed in later sections.

The hot springs and mud pots in the Sulphur Springs area have large concentrations of $\mathrm{SO}_{4}$ (greater than 1,000 milligrams per liter $(\mathrm{mg} / \mathrm{L})$ ) and small concentrations of $\mathrm{Cl}$ (less than $10 \mathrm{mg} / \mathrm{L}$ ). The $\mathrm{pH}$ of the water is between 0.6 and 5 . The $\mathrm{SiO}_{2}$ concentrations of acid sulfate water are large (generally greater than 200 $\mathrm{mg} / \mathrm{L}$ ), and concentrations of $\mathrm{Al}, \mathrm{Fe}, \mathrm{Mn}, \mathrm{Ca}$, and $\mathrm{Mg}$ are large relative to concentrations of $\mathrm{Na}$ and $\mathrm{K}$. The water chemistry reflects the hydrothermal alteration of the surrounding rhyolitic host rock. Bicarbonate 
$\left(\mathrm{HCO}_{3}{ }^{-}\right)$cannot exist as a major species in the water because of the low $\mathrm{pH}$. The chemistry of the hot springs changes seasonally because the springs are a mixture of condensed steam, dissolved gases, and shallow ground water. Cooler types of springs are formed by lower temperature gases bubbling through stream water or pools of water. This type of water also is acidic but less concentrated than hotter springs because of the smaller proportion of condensate. A condensed steam sample from the main fumarole in the Sulphur Springs area contained sulfuric acid and $\mathrm{NH}_{4}$ as the main ionic species (Goff and others, 1985). Hot gases at Sulphur Springs are approximately 99 percent $\mathrm{CO}_{2}$ and 1 percent $\mathrm{H}_{2} \mathrm{~S}$ by volume, with minor amounts of $\mathrm{H}_{2}$, $\mathrm{CH}_{4}$, and $\mathrm{NH}_{3}$. Chemical and isotopic analyses of acid springs, condensed steam, gaseous cold springs, and fumarole gases are presented in Goff and others (1985, tables 2-4) and Vuataz and Goff (1986, table 1). The composition of the gases resembles that of gases from other high-temperature geothermal systems elsewhere in the world (Goff and others, 1985).

The $\delta \mathrm{D}$ and $\delta^{18} \mathrm{O}$ content of the acid sulfate water in the Sulphur Springs area varies greatly. Vuataz and Goff (1986) attributed most of this variation to the processes of subsurface boiling and surface evaporation. They also attributed the $\delta^{18} \mathrm{O}$-depleted water that issues from one relatively cool spring to isotopic exchange between the spring water and the $\mathrm{CO}_{2}$ that vigorously passes through it.

The tritium content of acid sulfate springs is variable because spring water is generally a mixture of condensed steam and shallow ground water. The Men's Bathhouse Spring or mud pot (P-2, fig. 7) in the Sulphur Springs area, for example, is composed primarily of condensed steam and contains $2.1 \mathrm{TU}$, whereas the Women's Bathhouse Spring (P-3, fig. 7) contains a higher proportion of shallow ground water and 19 TU. The smaller tritium content of some surface hot springs, when considered with tritium data for the deep geothermal reservoir (discussed later), indicates that condensed steam is produced from water at least 50 years old (Goff and others, 1985).

\section{Hyorothermat Aneration}

Thermal fluids of active geothermal systems alter the rocks with which they come into contact. Typically acidic water and gases react with primary rock-forming silicate minerals to form clays. In the western part of Valles Caldera, hydrothermally altered rocks are distributed over about a $15-\mathrm{mi}^{2}$ area (fig. 10A) and are characterized by large amounts of kaolinite (Dondanville, 1978, p. 158). Hydrothermal alteration in the caldera has been investigated in detail by Lambert and Epstein (1980), Charles and others (1986), and Hulen and Nielson (1986). The altered area includes the upstream half of Redondo Creek Canyon and a similar tract across the drainage divide to the northeast and a tract that surrounds Sulphur Springs and extends into side canyons nearby. The altered area along Redondo Creek is in the Redondo Creek Graben of the resurgent dome and that surrounding Sulphur Springs is in a grabenlike structure bounded by at least three faults. Zones of alteration at the surface in these areas help delineate permeable channels where vapors rise to the surface; based on the zones of most intense alteration, such channels may be confined to fault traces and subsidiary fractures. Isotopic analyses of the hydrothermally altered rocks indicate the alteration to be a product of meteorically derived fluids (Lambert and Epstein, 1980; Goff and others, 1992).

\section{Geothema Anomaly}

High rates of near-surface heat flow and high subsurface temperatures characterize the western half of Valles Caldera and adjacent parts of the Jemez Plateau to the west. Heat flow in this region exceeds 3 heat flow units (HFU) and is as high as $6 \mathrm{HFU}$ over the Redondo Creek Graben and 15 HFU where discharge' from the geothermal reservoir passes under the caldera rim (Reiter and others, 1976; Goff and others, 1988). The total heat discharge for the Valles Caldera, estimated by Sorey (1985) to be $18 \times 10^{6}$ calories per second (cal/s), suggests a shallow heat source, probably a cooling magma chamber, located beneath the western part of the Valles Caldera. Hulen and Nielson (1986) estimated the depth to the top of the magma body to be about $16,000 \mathrm{ft}$. Temperature gradients measured in wells outside Valles Caldera suggest that heat flow increases markedly as the rim of the caldera is approached from the west (Reiter and others, 1976), and temperature gradients within the caldera are markedly greater than those outside the caldera rim. Shallow temperature gradients within the caldera are presented in figure $10 \mathrm{~B}$. Temperature gradients exceed $25^{\circ} \mathrm{F}$ per $100 \mathrm{ft}$ in several locations within the caldera (Swanberg, 1983, fig. 7). The contours show a sharp decrease in temperature to the east and southeast within the caldera. Bodvarsson and others (1982) suggested that the sharp decrease in temperature gradients between Redondo Creek and 

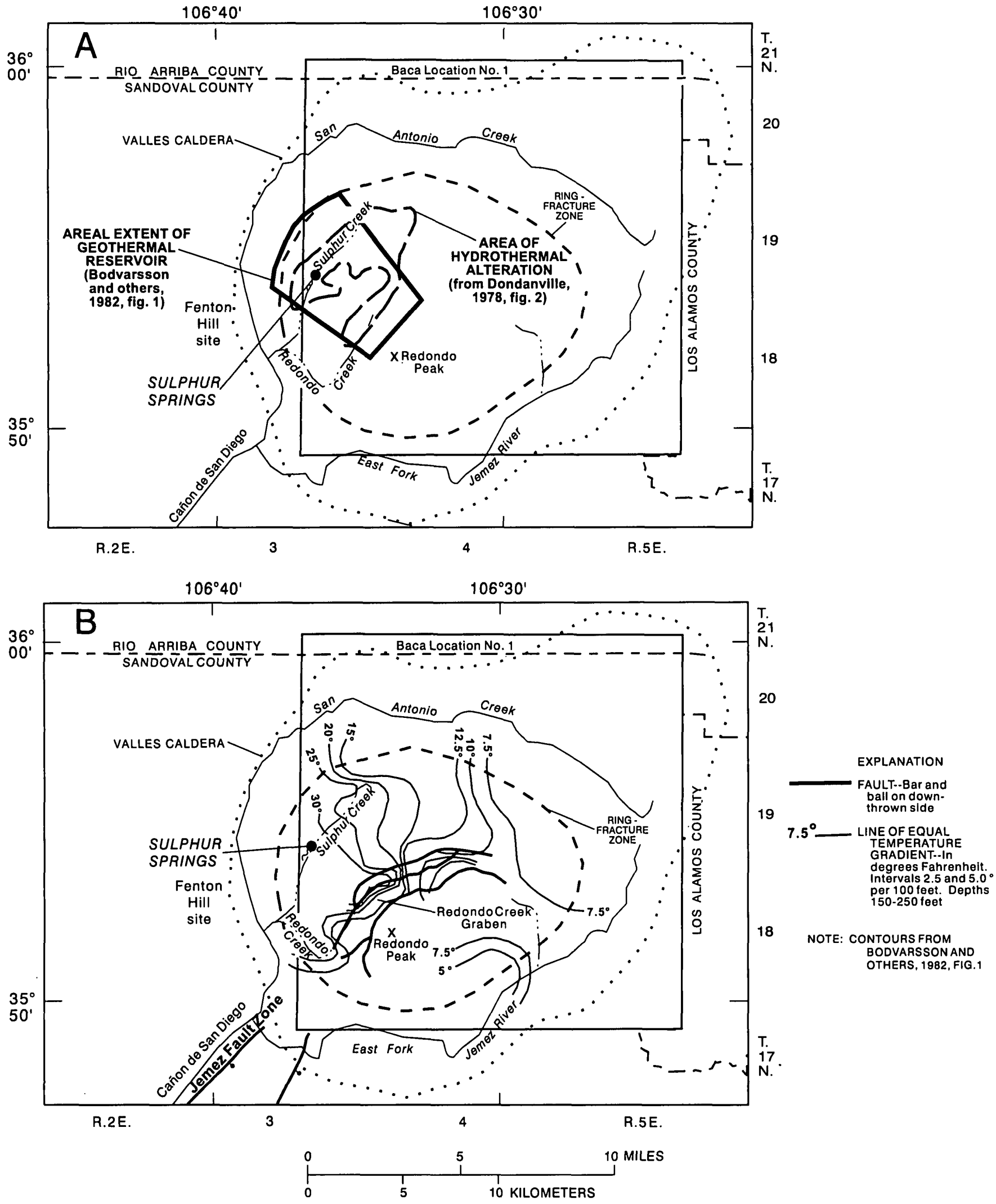

Figure 10.--(A) Areal extent of hydrothermal alteration and the geothermal reservoir and (B) shallow temperature gradients in the Valles Caldera. 
Redondo Peak probably results from the presence of a permeability barrier in this area or from an inflow of colder ground water from the southeast into the underlying hotter geothermal reservoir. Areas of low, near-surface temperature gradients include Valle Grande and perhaps Valle Toledo, where cool ground water flowing through thick valley fill likely transports away much of the heat that is transferred upward by conduction through the underlying rock.

The area of high temperature gradients encompasses the area of active hydrothermal alteration (figs. 10A, B), as defined by Dondanville (1978, p. 158), which probably reflects convective transport of heat to the surface by rising vapor. High temperature gradients elsewhere in the western part of the caldera also probably reflect convective transport of heat by rising geothermal fluids. Measurements in LANL well GT-2 (Pettitt, 1975a) just outside the west rim of the caldera (fig. 5) indicate thermal gradients in the basement rocks that are markedly less than those in the overlying section of sedimentary rocks in which most ground-water flow occurs. These observations are consistent with the convective transport of heat by ground water, in this case laterally out of the caldera, which is discussed in more detail later in the report.

\section{Geothermal Reservoir}

The current understanding of the Valles Caldera geothermal reservoir has developed from geothermal exploration conducted in the caldera between 1970 and 1982 and other investigations in and around the caldera, such as the CSDP, which drilled the three deep holes into the geothermal system between 1984 and 1988. The general configuration of the geothermal system was summarized by Goff and others (1992) and is illustrated in figure 11. In the geothermal system, meteorically derived water moves downward from the aquifers in the caldera fill and recharges the geothermal reservoir in intracaldera tuffs and precaldera rocks at depths of $6,500 \mathrm{ft}$ or more and at temperatures reaching $330{ }^{\circ} \mathrm{C}$. The geothermal water then rises convectively to depths of 2,000 ft or less. A vapor zone (or zones) containing steam, $\mathrm{CO}_{2}$, and other gases has formed above parts of the geothermal saturated zone. In the Sulphur Springs area, acid springs, fumaroles, and mud pots are at the top of the vapor zone and a zone of condensation, about $15 \mathrm{ft}$ thick, exists at the surface (Goff and others, 1992, p. 185). The heated water of the geothermal system flows out the caldera to the west and southwest under the Jemez Plateau and along the Jemez Fault Zone and in the semipermeable Paleozoic rocks that border the fault zone. This geothermal water mixes with other ground water as it flows along the fault zone, and some of this mixed or derivative water issues as hot springs in Cañon de San Diego. Drilling has identified two subsystems, the Redondo Creek subsystem and the Sulphur Creek subsystem (Goff and others, 1992). These and other complexities of the geothermal system are discussed in following sections.

\section{Geometry and Hydrologic Properties}

The permeability, stratigraphy, structure, and other aspects of the geothermal reservoir have been investigated with geologic mapping, drilling of test holes, mapping of geothermal gradients, and the use of other geophysical techniques; results of these investigations are presented in Bodvarsson and others (1982), Garg and Riney (1982), Hulen (1982), and Grant and others (1984). Because the Redondo Creek subsystem exhibits the greatest promise for geothermal development, it has been more extensively studied than other parts of the system.

The permeability of the Redondo Creek geothermal subsystem is controlled mainly by stratigraphy and fault-related structures. The permeable horizons, evidenced by entry points of thermal fluids in the Baca wells, were identified by Hulen (1982, fig. 4) and Grant and others (1984, figs. 16-18). Hulen (1982) concluded that the most transmissive stratigraphic horizons occur in tuffaceous sandstones and nonwelded tuff units scattered throughout the Bandelier Tuff; however, the interstitial permeability of the welded Bandelier Tuff is small. Permeable units are not continuous throughout the entire Redondo Creek area, but some can be correlated between drill holes. The thickness of permeable units intersected by any given well in the Redondo Creek area amounts to no more than 8 percent of total formation thickness on average (Hulen, 1982, p. 11). Grant and others (1984) performed a detailed analysis of borehole geophysical data for wells drilled in the Redondo Creek area and concluded that at least two main transmissive zones exist in the area. The deeper transmissive zone, which is about $500 \mathrm{ft}$ thick, was placed between the Bandelier Tuff and the underlying Paliza Canyon Formation; this zone may correspond to the sequence of units informally designated the "Lower 


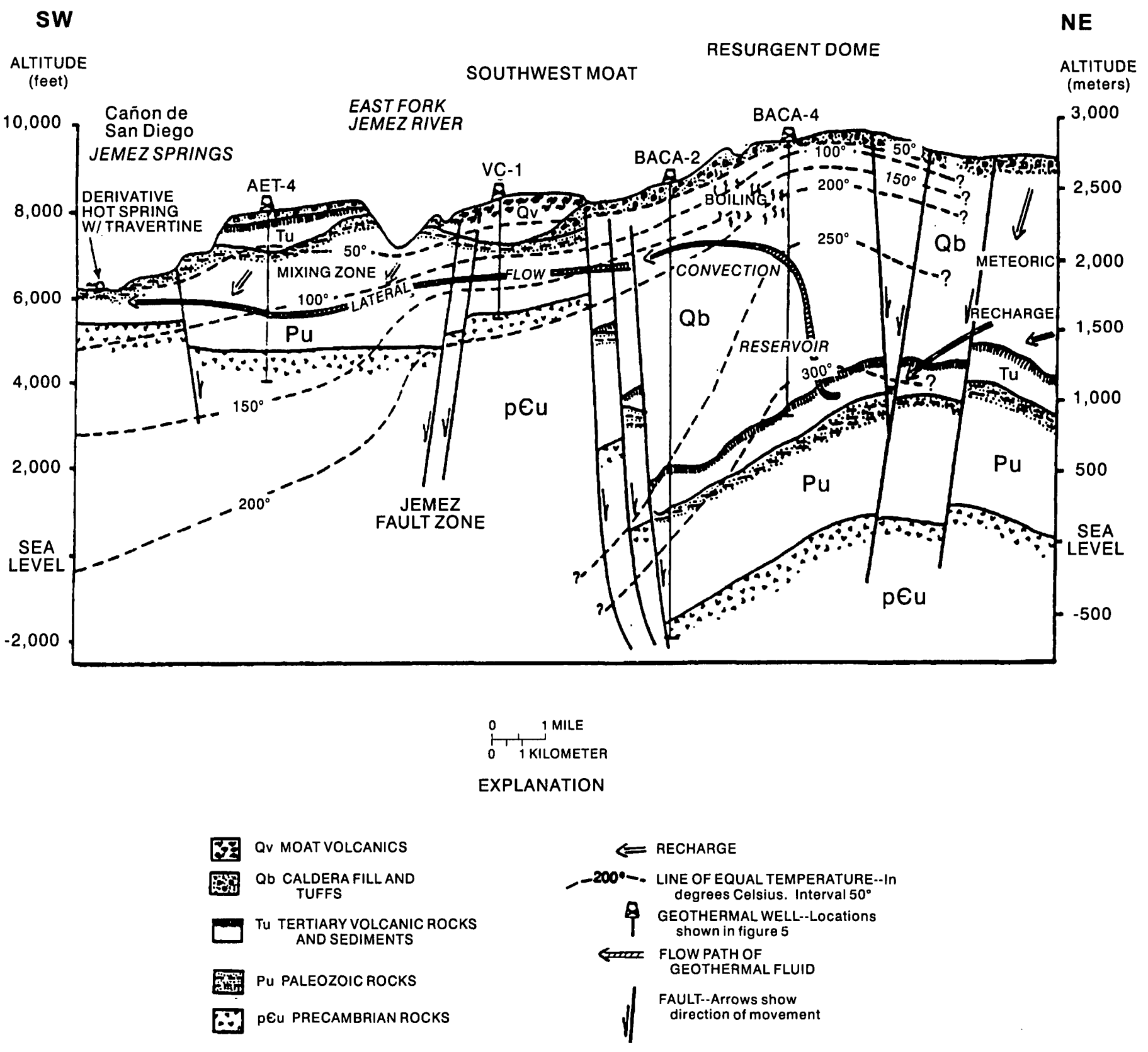

Figure 11.--Generalized section of southwestern Valles Caldera and upper Cañon de San Diego showing the active geothermal system (modified from Goff and others, 1992, fig. 6, and published with permission). 
Tuffs" by Nielson and Hulen (1984). The upper transmissive zone, which is generally more productive than the lower zone, is within the Bandelier Tuff and may actually consist of two separate zones, at about 4,900 and 5,900 ft above sea level, respectively, in a region that has an average land-surface altitude of about 9,000 ft (Grant and others, 1984).

Garg and Riney (1982, p. 31) concluded that most of the permeability in the geothermal reservoir occurs as secondary permeability primarily in the fault and fracture network. The structural permeability in the Redondo Creek area occurs primarily along the highangle, northeast-trending, normal faults that form the Redondo Creek Graben (figs. 4A, B) and along fractures associated with these faults (Hulen, 1982). The permeable fluid channels are marked by zones of hydrothermal alteration, indicating that the Redondo Creek geothermal subsystem has developed mostly or entirely under water-dominated conditions as opposed to vapor-dominated conditions (Hulen and Nielson, 1986).

The Sulphur Springs geothermal subsystem of the geothermal reservoir is not as well defined as the Redondo Creek subsystem because fewer holes have been drilled in this area. The alignment of hydrothermal alteration and other geothermal features along fault traces indicates that faults and related structures control the flow of thermal fluids in both the Redondo Creek and Sulphur Springs geothermal subsystems (Goff and others, 1985). Both areas are bounded by high-angle faults that trend northnortheast. CSDP holes VC-2A and VC-2B in the Sulphur Springs area (fig. 5) reveal a vapor-dominated zone, about $790 \mathrm{ft}$ thick, overlying a liquid-dominated zone; the two zones are separated by about $800 \mathrm{ft}$ of sealed caldera-fill rocks (Goff and others, 1992). The liquid-dominated zone consists of stacked hydrothermal aquifers. Most fluid in this zone circulates in the caldera-fill sequence of tuffs, the sandstones of the Santa Fe Group that immediately underlie the tuff, and the deeper Precambrian quartz monzonite that is separated from the Santa Fe Group by a 2,500-ft thickness of Paleozoic rocks.

The Sulphur Springs subsystem may be isolated structurally from the Redondo Creek subsystem (Goff and others, 1985, fig. 9). Moreover, differences in the chemical and isotopic compositions of water samples collected from deep wells in each area (discussed in the following section) suggest two separate (or poorly connected) hydrothermal subsystems within the caldera. Chemical and thermal evidence also indicate that each subsystem has its own zone of upflow and lateral outflow of thermal water: outflow from the Redondo Creek subsystem flowing beneath the southwestern rim of the caldera and Cañon de San Diego and outflow from the Sulphur Springs subsystem flowing westward beneath the Jemez Plateau (Goff and others, 1985).

The internal geometry of the Valles Caldera geothermal reservoir is detailed and complex. Interlayering of rocks with vastly different permeabilities that are intersected by steeply dipping faults divides the reservoir horizontally and vertically into blocks. Thus, the more highly permeable stratigraphic and structural features of the geothermal reservoir remain interconnected, but in an undetermined way. Faust and others (1984) assumed for purposes of modeling the reservoir that, at the scale of the caldera, the complex interconnection of highly permeable features can be considered equivalent to a porous medium. The performance of an individual well, however, depends to a large degree on the faults, joints, and stratigraphic units that the well intersects and the interconnection of those faults and joints with other permeable structures and stratigraphic units (Garg and Riney, 1982, p. 31). The lack of interference effects among some pairs of pumping and observation wells during production tests suggests effective hydraulic isolation along some subsystem, or block, boundaries.

\section{Areal Exient}

Thus far, drilling has defined only a portion of the Valles Caldera geothermal reservoir. Consequently, estimates of the areal extent and thickness of the reservoir can be inferred only from geologic and geophysical data. Several workers in the late 1970's (cited in Faust and others, 1984) estimated the areal extent of the reservoir to be about 60 to $66 \mathrm{mi}^{2}$, which is approximately equal to the area encircled by the ringfracture zone of the caldera. More recent work, however, indicates that these estimates are unreasonably large and that the geothermal reservoir is much smaller than the caldera. Bodvarsson and others (1982) estimated the areal extent of the reservoir to be about $15 \mathrm{mi}^{2}$, and placed the western limit of the reservoir at the western edge of the ring-fracture zone of the caldera (fig. 10). Wilt and Vonder Haar (1986), for purposes of reservoir simulation, made three estimates of the areal extent of the reservoir based on 
geophysical and drill-hole data and on different sets of assumptions. The values ranged from about 8.6 to 11.6 $\mathrm{mi}^{2}$ depending on how far the reservoir was assumed to extend northeast of the Redondo Creek area and whether the Sulphur Creek area was included in the reservoir. (As noted above, the CSDP identified a saturated zone below Sulphur Creek, so the largest estimate of Wilt and Vonder Haar (1986) is probably a more realistic value.) Faust and others (1984), when developing a simulation model of the geothermal system, initially used an area of $15 \mathrm{mi}^{2}$, the same as that of Bodvarsson and others (1982). However, in the final model of Faust and others (1984), the areal extent of the reservoir was reduced to only $12 \mathrm{mi}^{2}$.

\section{Thickness}

Estimates of the thickness of the geothermal reservoir also have differed among investigators. The top of the reservoir is thought by most investigators to be the bottom of a small-permeability "caprock" formed within the Quaternary Bandelier Tuff as a product of hydrothermal alteration (Bodvarsson and others, 1982; Grant and others, 1984; Wilt and Vonder Haar, 1986). The bottom of the caprock, or top of the reservoir, in the Redondo Creek area is about 6,000 to $7,000 \mathrm{ft}$ above sea level or about 2,000 to $3,000 \mathrm{ft}$ below land surface. The caprock extends above much of the reservoir, but its lateral extent has not been fully defined by drilling. The presence of fumaroles indicates that the caprock does not form a perfect seal and that leaks exist at least along fault zones. The bottom of the reservoir is more difficult to define. Nearly all fluid production in exploratory wells is produced from fractures or thin beds in the Bandelier Tuff below the caprock, a zone generally less than $4,000 \mathrm{ft}$ thick in the Redondo Creek area (Grant and others, 1984). No substantial production of geothermal fluids in drill holes has been found below the Tertiary Paliza Canyon Formation (table 1). However, deeper permeable zones exist below the Paliza Canyon Formation as evidenced by wells that do not produce geothermal fluids but accept high injection rates of fluids (Garg and Riney, 1982, p. 35). Bodvarsson and others (1982) defined the bottom of the reservoir as the bottom of the Bandelier Tuff and estimated the average reservoir thickness to be $2,000 \mathrm{ft}$, relatively thin compared with other estimates. Union Oil Company estimated an average reservoir thickness of $3,000 \mathrm{ft}$ based on their analysis of reservoir tests (Faust and others, 1984). Wilt and Vonder Haar (1986) placed the bottom of the reservoir at the bottom of the Paliza Canyon Formation and suggested that the reservoir thickens to the southeast; they estimated the thickness of the reservoir in the Redondo Creek area to range from about 2,500 to 5,000 ft. Faust and others (1984) placed the bottom of the reservoir at the contact with the basement Precambrian granite, making the reservoir about $6,000 \mathrm{ft}$ thick, which they recognized as an optimistic assumption.

\section{Temperature and Pressure Distributions}

Temperature and pressure also vary from well to well and with depth and time of measurement. Estimates of the temperature distribution in the reservoir under the Redondo Creek area are presented in Grant and others (1984). Reservoir temperatures measured in the Baca wells range from about $225^{\circ} \mathrm{C}$, just below the caprock to about $330^{\circ} \mathrm{C}$ in Baca well 11 at a depth of about $6,690 \mathrm{ft}$, which corresponds to an altitude of about $2,380 \mathrm{ft}$. Temperature profiles of the deep wells are characterized by convex-upward inflections that separate higher gradients (about 0.089 ${ }^{\circ} \mathrm{C} / \mathrm{ft}$ ) near the surface from lower gradients (about $0.012^{\circ} \mathrm{C} / \mathrm{ft}$ ) at greater depths (fig. 12). The higher gradients are indicative of conductive heat transfer in the smaller permeability caprock; the lower temperature gradients, which occur below about 7,500 $\mathrm{ft}$ in altitude, are indicative of a convective system of circulating hydrothermal fluids (White, 1986).

Reservoir temperatures estimated using chemical geothermometers range between 250 and $300{ }^{\circ} \mathrm{C}$ (Truesdell and Janik, 1986; White, 1986), in general agreement with measured temperatures. Maximum reservoir temperatures measured in Baca wells in the Sulphur Creek area were lower than those measured in wells in the Redondo Creek area and ranged between 157 and $283^{\circ} \mathrm{C}$ (Goff and others, 1985, table 1).

In the Redondo Creek area, pressures measured in the production zones of the Baca wells ranged between 450 and 1,850 pounds per square inch $\left(\mathrm{lb} / \mathrm{in}^{2}\right)$ (Garg and Riney, 1982, table 4). The highest pressure recorded was $1,850 \mathrm{lb} / \mathrm{in}^{2}$ at an altitude of $3,102 \mathrm{ft}$ in Baca well 11. Grant and others (1984) analyzed pressure data for the Redondo Creek area and drew the following conclusions. Reservoir pressure, when plotted against altitude, defines a straight line with a slope of about 0.349 pound per square inch per foot $\left(\mathrm{lb} / \mathrm{in}^{2} / \mathrm{ft}\right)$, which corresponds to a hydrostatic gradient for a temperature of about $260^{\circ} \mathrm{C}$. The close correlation between pressure and altitude in the 


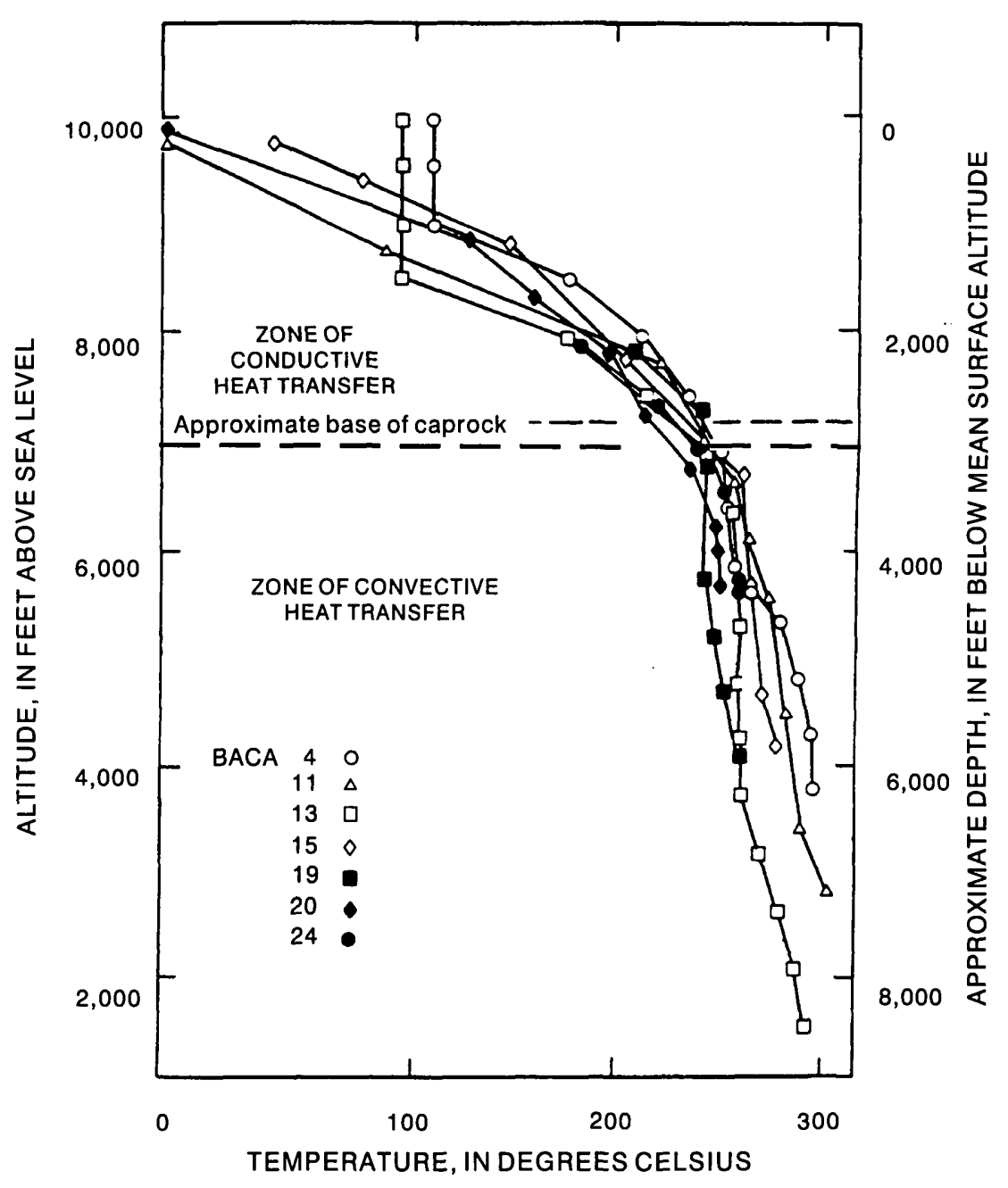

Figure 12.--Temperature profile of seven Baca wells (modified from White, 1986, fig. 3).

Redondo Creek area indicates that the subsystem is hydraulically connected and possibly that the upflow of fluids occurs in regions where the temperature exceeds $260^{\circ} \mathrm{C}$. Reservoir pressure extrapolates to atmospheric pressure at about $7,875 \mathrm{ft}$ in altitude, which is considered to be the nominal piezometric surface of the reservoir in the Redondo Creek area. Pressures measured in Baca wells in the Sulphur Creek area ranged from 75 to $1,400 \mathrm{lb} / \mathrm{in}^{2}$ (Goff and others, 1985, table 1).

\section{Hydraulic Properties}

Selected reservoir properties, such as the permeability, thickness, temperature, and pressure measured in Baca wells, have been summarized by Garg and Riney (1982, table 4) and Goff and others $(1985$, table 1) and also are discussed in Union Oil Company reports. Grant and others (1984) conducted a detailed analysis of properties of selected Baca wells in the Redondo Creek area. Because the permeability of the reservoir is not uniform but rather is highly variable among stratigraphic units and largely controlled by fractures, hydrologic properties can vary significantly from well to well, and values determined for an individual well are not necessarily representative of the reservoir in general. For example, in the Redondo Creek area, the permeability-thickness product $(\mathrm{kH})$ reported for selected Baca wells ranged between 2,600 and 23,800 millidarcy-ft (mdarcy-ft) (Garg and Riney, 1982, table 4). Because of such variability, Grant and others $(1984$, p. 1413) concluded that there is little basis on which to assign a $\mathrm{kH}$ value representative of the entire geothermal reservoir.

Representative values of physical and hydrologic properties have been estimated for the geothermal reservoir, despite the large variability from well to well. These values have been estimated from reservoir- 
testing, stream-depletion, and geothermal-production analyses. For example, a 1975-76 fieldwide pressure interference test in the Redondo Creek area to evaluate the hydraulic connectivity of fractures yielded a permeability-thickness product of about 6,000 mdarcy-ft (Garg and Riney, 1982, p. 34). Reservoir properties estimated by Bodvarsson and others (1982), Union Geothermal Company of New Mexico (1981), and Faust and others $(1983,1984)$ for the purpose of developing numerical simulation models of the reservoir are presented in table 5; each set of values was developed for a different type of model. Faust and others (1983) provided a detailed listing of the hydrologic and thermal parameters used to develop a calibrated three-dimensional, finite-difference model of the geothermal reservoir and adjoining aquifer.
Union Oil reanalyzed all well-test data in 1982 and revised their 1981 estimated values of average permeability thickness and porosity thickness to 4,000 mdarcy-ft and $150 \mathrm{ft}$, respectively (Faust and others, 1984, p. 605). Faust and others (1984) estimated horizontal permeability to be greater than vertical permeability by about a 4 to 1 ratio; Union Oil, however, assumed the horizontal permeability to be half the vertical permeability. Faust and others (1983, 1984) compared and contrasted estimated properties presented by different workers. All estimated values of the permeability-thickness product of the Valles Caldera geothermal reservoir are smaller than those of other geothermal fields, which range from 20,000 to more than 100,000 mdarcy-ft (Garg and Riney, 1982, p. 34).

Table 5. Estimated reservoir properties of the Valles Caldera geothermal reservoir used in numerical simulation models of the reservoir

[ ${ }^{\circ} \mathrm{C}$, degrees Celsius; --, no data; $\mathrm{cm}$, centimeter $]$

\begin{tabular}{|c|c|c|c|}
\hline Property (unit of measurement) & $\begin{array}{l}\text { Bodvarsson } \\
\text { and others } \\
(1982)\end{array}$ & $\begin{array}{c}\text { Union } \\
\text { Geothermal } \\
\text { Company of } \\
\text { New Mexico } \\
\text { (1981) }\end{array}$ & $\begin{array}{c}\text { Faust and } \\
\text { others } \\
(1983,1984)\end{array}$ \\
\hline Area (square miles) & 15.4 & 60 & 16 \\
\hline Average thickness (feet) & 2,000 & 3,000 & 6,000 \\
\hline Temperature (degrees Celsius) & 300 & ${ }^{1} 300$ & ${ }^{2} 220-295$ \\
\hline Pressure (pounds per square inch) & 1,600 & 1,200 & $2520-1,880$ \\
\hline Porosity (unitless) & 0.05 & 0.03 & 0.03 \\
\hline Porosity thickness (feet) & 100 & 90 & 180 \\
\hline \multicolumn{4}{|l|}{ Permeability } \\
\hline Horizontal (millidarcy) & 3.0 & 2.0 & 3.0 \\
\hline Vertical (millidarcy) & - & 4.0 & $0.075-0.75$ \\
\hline Permeability thickness (millidarcy-foot) & 6,000 & 6,000 & 18,000 \\
\hline Rock density (grams per cubic centimeter) & 2.65 & - & 2.65 \\
\hline Rock compressibility (square centimeter/dyne) & - & $7.25 \times 10^{-11}$ & $7.25 \times 10^{-11}$ \\
\hline Thermal conductivity (ergs/second $\mathrm{cm}{ }^{\circ} \mathrm{C}$ ) & $2 \times 10^{5}$ & $1.44 \times 10^{5}$ & $1.44 \times 10^{5}$ \\
\hline Rock heat capacity (ergs $/ \operatorname{gram}^{\circ} \mathrm{C}$ ) & $9.5 \times 10^{6}$ & -- & $9.5 \times 10^{6}$ \\
\hline
\end{tabular}

${ }^{1}$ Maximum temperature.

${ }^{2}$ Range, increasing with depth. 
Bodvarsson and others (1982) estimated the capacity of the geothermal reservoir to be $2.2 \times 10^{12}$ pounds (lb) of geothermal fluid in place, based on an area of about $15.4 \mathrm{mi}^{2}$, a porosity-thickness product of about $100 \mathrm{ft}$, and a fluid density of 51.5 pounds per cubic feet $\left(\mathrm{lb} / \mathrm{ft}^{3}\right)$, which corresponds to a temperature of $230^{\circ} \mathrm{C}$. Union Oil Company estimated the reservoir capacity to be about $4.7 \times 10^{12} \mathrm{lb}$ of geothermal fluid in place based on two methods of analysis, a depletion equation and an interference test, and a reservoir area of about $43 \mathrm{mi}^{2}$. The close agreement between the two estimated capacities would appear fortuitous, given the large differences in estimated reservoir area on which the capacities are based (Bodvarsson and others, 1982).

Vapor- or steam-dominated zones above the liquid-dominated zones have been penetrated in wells drilled in both the Redondo Creek and Sulphur Creek areas. Vapor-dominated conditions, in which steam is the pressure-controlling fluid phase and the vertical pressure profile is close to vapor-static rather than hydrostatic, may also exist in zones where existing well-pressure measurements are inadequate to delineate such conditions. This type of vapordominated zone develops from the upflow of steam from an underlying region of boiling liquid. The development of vapor-dominated conditions may be related to the depressurizing that accompanied the breaching of the southwestern caldera rim and draining of the caldera lake approximately $0.5 \mathrm{Ma}$ (Trainer, 1984; Goff and others, 1992). Following this event, liquid levels dropped about $1,000 \mathrm{ft}$ below land surface. The lateral extent of vapor-dominated zones is not well defined, and not every well has penetrated such zones. The vertical extent of vapor-dominated zones is partly determined by the variable $\mathrm{CO}_{2}$ content of the hydrothermal fluid. The presence of dissolved $\mathrm{CO}_{2}$ extends the range of temperatures and depth over which boiling can occur. The interface between the bottom of the vapor-dominated zone and the top of the liquid-dominated zone is not necessarily explicit (Goff and others, 1992). For example, Grant and others (1984, p. 1412) estimated the bottom of the two-phase zone (top of the liquid-dominated zone) in the hotter part of the Redondo Creek subsystem to extend downward to a depth of 4,100 ft (altitude of approximately $4,900 \mathrm{ft}$ ) where temperatures are near $250{ }^{\circ} \mathrm{C}$. More recent estimates (Goff and others, 1992, p. 193) place the top of the liquid-dominated zone at depths of 1,650 to $1,970 \mathrm{ft}$ and temperatures of approximately $200{ }^{\circ} \mathrm{C}$ (fig. 9).

\section{Geochemistry of Geothermal Fluids}

The chemical and isotopic composition of fluids in the geothermal reservoir is primarily determined by the composition of the source fluids and the chemical interaction between reservoir fluids and reservoir rock. Evaporation associated with boiling can also affect the composition of water in the geothermal reservoir. The composition of reservoir fluids is useful in interpreting the source and movement of reservoir fluids and in estimating reservoir properties. The composition of reservoir fluids in the Valles Caldera is discussed in Delany and Truesdell (1982), Goff and others (1985), Truesdell and Janik (1986), Vuataz and Goff (1986), White (1986), and Goff and others (1992); a summary of those findings is presented here. Most geochemical data on reservoir fluids comes from samples collected from Baca wells in the Redondo Creek area during the 1970 's and early 1980's. More recently, geochemical data have been obtained for the CSDP wells. Problems associated with the collection of samples and interpretation of analyses of geothermal fluids, such as those caused by local boiling in the reservoir around the well bore, are discussed by Truesdell and Janik (1986) and White (1986). Other investigators report concentrations of constituents in the reservoir fluids differently; for example, some investigators report concentration on a total-fluid basis, which adjusts measured concentrations for steam loss, and others report concentrations on an "as-analyzed" basis. Thus, direct comparisons of data are not always readily possible, and concentrations reported may not actually represent the chemistry of the fluid in the reservoir.

Water in the geothermal reservoir has geochemical characteristics that distinguish it from other thermal water in the caldera. In general, the reservoir below Sulphur Springs and Redondo Creek contains a near-neutral, chloride-type water containing about 7,000 $\mathrm{mg} / \mathrm{L}$ dissolved solids and anomalously large concentrations of $\mathrm{As}, \mathrm{B}, \mathrm{Br}, \mathrm{Cs}, \mathrm{Li}, \mathrm{Rb}$, and other trace elements (Goff and others, 1992). Geochemical differences distinguish water in the Redondo Creek subsystem from that in the Sulphur Springs subsystem.

Concentrations of major and trace constituents in fluid samples collected between 1973 and 1982 from 10 Baca wells in the Redondo Creek area were summarized by White (1986, table 1); multiple samples were ana'-'zed from most wells. Concentrations of constituents, expressed in milligrams per liter on a total produced fluid basis, are in the following ranges for most wells: $\mathrm{SiO}_{2}, 200$ to $600 ; \mathrm{Na}, 900$ to 1,$500 ; \mathrm{K}, 150$ to $250 ; \mathrm{Ca}, 3$ to $25 ; \mathrm{Mg}$, 
less than $1.0 ; \mathrm{Cl}, 1,500$ to 2,$500 ; \mathrm{SO}_{4}, 20$ to $50 ; \mathrm{HCO}_{3}$, 20 to $160 ; \mathrm{As}, 1$ to $4 ; \mathrm{B}, 10$ to $22 ; \mathrm{Br}, 3.5$ to $8 ; \mathrm{F}, 2.5$ to 7.5; and $\mathrm{Li}, 10$ to 20 . The range of constituent concentrations in reservoir fluids based on multiple samples collected from five Baca wells in 1982 is illustrated in figure 13. The $\mathrm{pH}$ of geothermal reservoir water measured in the field was about 7.2 (Goff and Grigsby, 1982); the calculated $\mathrm{pH}$ of reservoir water was 5.57 to 6.41 , with a mean $\mathrm{pH}$ of 5.9 (White, 1986). Samples of reservoir fluid from the Sulphur Springs subsystem contain slightly larger concentrations of dissolved minerals than the fluid from the Redondo Creek subsystem (Goff and others, 1992). The composition of water from Precambrian rocks at the bottom of CSDP hole VC-2B (fig. 5) in the Sulphur Springs area suggests that this water is derived from a mix of geothermal reservoir fluid and saline pore fluid, which has been sampled in Precambrian rocks at the Fenton Hill site (fig. 5) on the flank of the caldera west of Sulphur Springs (Goff and others, 1992).

Although no thermal springs in the caldera have water chemistry that resembles that of the deep geothermal fluids sampled from wells, the thermal springs at Soda Dam and Jemez Springs in Cañon de San Diego (fig. 5) have geochemical characteristics similar to the deep geothermal fluids within the caldera. Water issuing from these springs is a mixture of water from the lateral, subsurface flow of reservoir fluids to the southwest along the Jemez Fault Zone and local, dilute ground water (Trainer, 1974; Goff and others, 1992); this derivative of reservoir fluids is discussed later in the report.

The dissolved mineral content of water in the geothermal reservoir is similar to volcanic geothermal water from other areas, and concentrations of dissolved constituents reflect interaction with reservoir rocks (Truesdell and Janik, 1986). White (1986) concluded that geothermal fluids within the Valles Caldera are in general chemical equilibrium with secondary minerals of the geothermal reservoir, which suggests stable temperatures during development of the geothermal reservoir.

The gas content of the geothermal fluids also is typical of volcanic geothermal systems. Reservoir fluid has an incondensible gas content (principally $\mathrm{CO}_{2}$ ) of about 0.4 to 1.5 percent (mean about 0.8 percent) by mass (Grant and others, 1984), and $\mathrm{CO}_{2}$ composes more than 98 mole percent of the incondensible gases (Truesdell and Janik, 1986). Other gases, in order of decreasing abundance, are: $\mathrm{H}_{2} \mathrm{~S}, \mathrm{~N}_{2} \mathrm{H}_{2}, \mathrm{CH}_{4}, \mathrm{NH}_{3}, \mathrm{Ar}$, $\mathrm{He}$, and other noble gases. Concentrations of the principal gases in fluids from the Baca wells are discussed in Truesdell and Janik (1986, tables 4 and 5) and White (1986, table 2). Smith and Kennedy (1985) presented the elemental and isotopic composition of noble gases from the geothermal reservoir and on the basis of these data identified two compositions of fluid in the Redondo Creek subsystem. All gases in the reservoir, with the exception of $\mathrm{He}$, probably originate from (1) atmospheric gases dissolved in recharge, (2) thermal metamorphism of nearby carbonate rocks, and (3) other chemical reactions in the reservoir (Truesdell and Janik, 1986). The high ${ }^{3} \mathrm{He} /{ }^{4} \mathrm{He}$ ratios in reservoir gases indicate helium derived from the mantle and possibly the presence of a magmatic source below the caldera floor (Smith and Kennedy, 1985; Goff and others, 1992).

Isotope data (Trainer, 1978, table 8c; Truesdell and Janik, 1986, table 3; Vuataz and Goff, 1986, table 1; White, 1986, table 3; and Goff and others, 1992, table 1) indicate a meteoric origin of the fluids in the geothermal reservoir and ${ }^{18} \mathrm{O}$ enrichment of geothermal fluid relative to the meteoric-water line for the Jemez Mountains region (fig. 14). The amount of enrichment is typical of that measured in other geothermal systems and was attributed by Vuataz and Goff (1986) to oxygen exchange between isotopically heavier reservoir rocks and isotopically lighter water. Other processes that modify the isotopic composition of fluids in geothermal systems include mixing of nonthermal and thermal water; boiling in the upper part of the reservoir; and isotopic exchange between water and gases such as $\mathrm{CO}_{2}$. The isotopic composition of oxygen in reservoir fluids differs among the Baca wells. In general, these isotopic differences are attributed to different recharge source areas for the fluid and to the degree of boiling of the fluid. Truesdell and Janik (1986) and White (1986) presented further explanations of the isotopic variations in the geothermal reservoir.

The tritium content of samples collected from five Baca wells in 1982 and from three CSDP wells between 1985 and 1990 ranged between 0.18 and 1.1 TU (Vuataz and Goff, 1986;.Goff and others, 1992). Using this range of tritium values and assuming a piston-flow model of the reservoir as one extreme and a homogeneously mixed model of the reservoir as the other, Vuataz and Goff (1986) calculated the residence time of water in the geothermal reservoir to be between 60 and 10,000 years and on the basis of these and other geologic and geochemical data concluded that the mean residence time is at least several hundred years. 


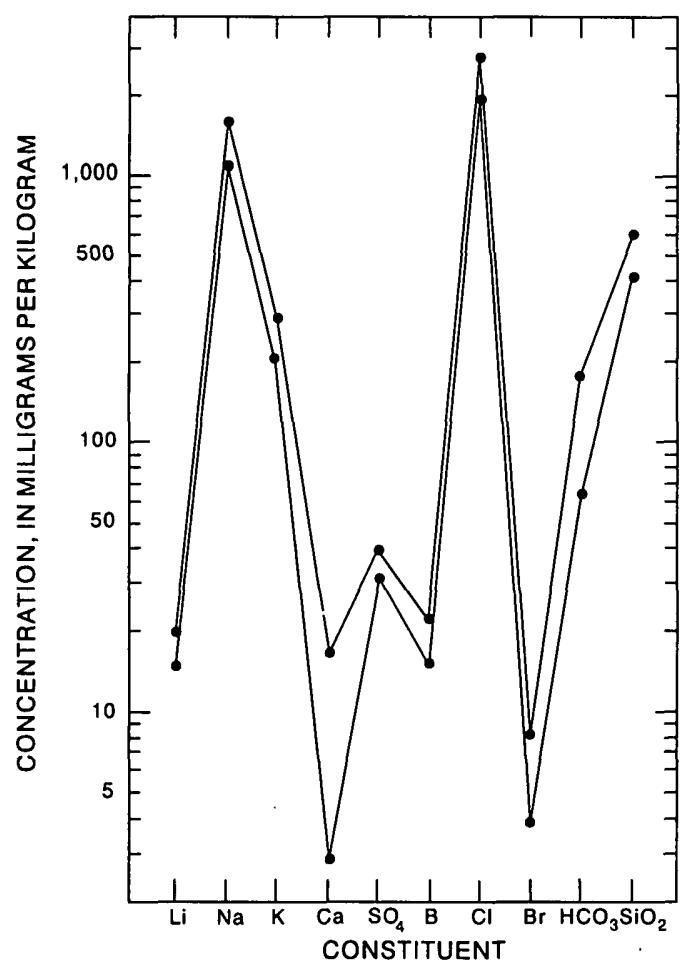

Figure 13.--Range of concentrations of geothermal-reservoir fluids collected in 1982 from five Baca wells (modified from Truesdell and Janik, 1986, fig. 4). Well locations shown in figure 5 .

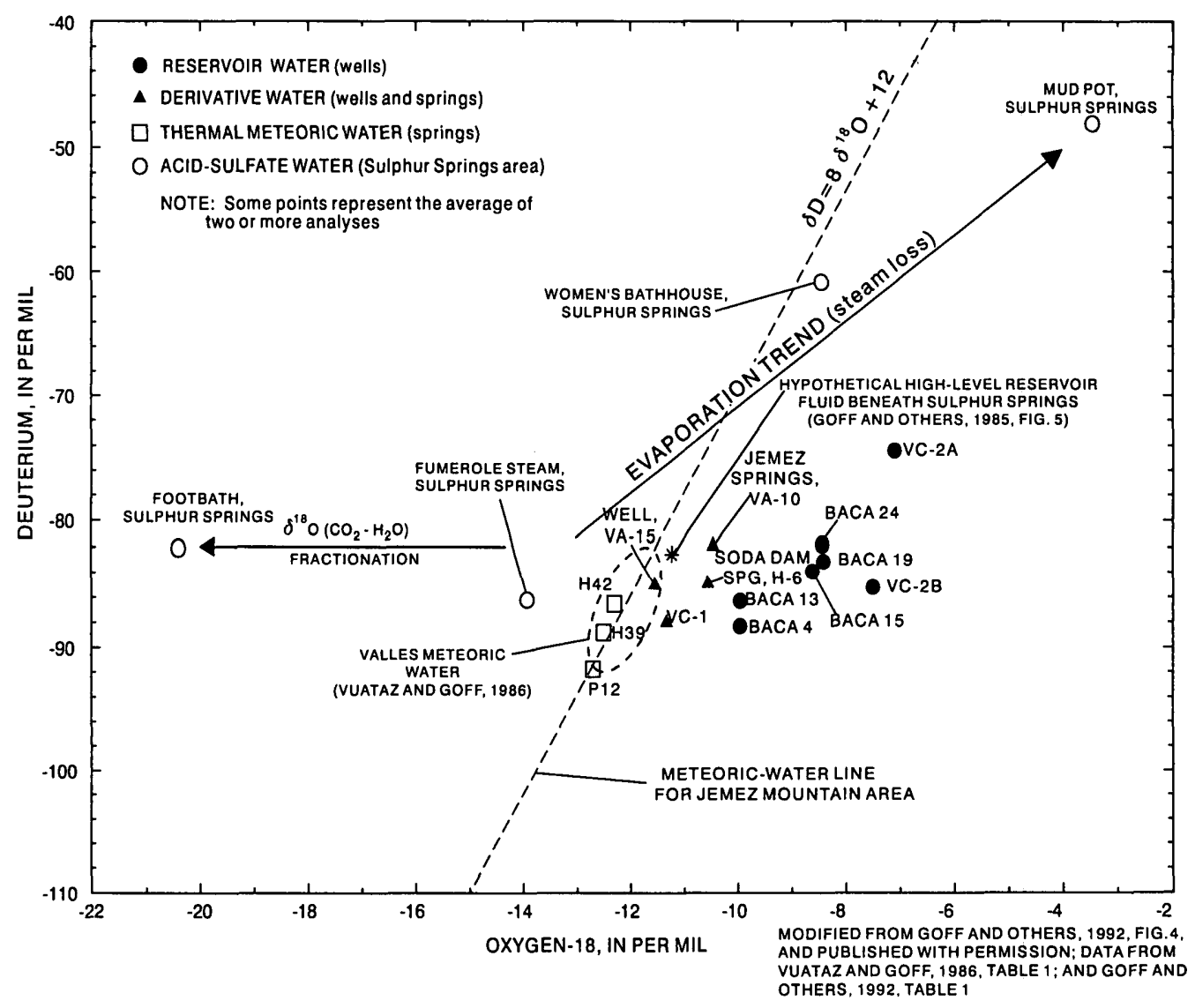

Figure 14.--Relation of deuterium and oxygen-18 for selected thermal and nonthermal fluids in the Jemez Mountains region. 


\section{Fluid Flow in the Reservoir}

Several conceptual models of fluid flow in the geothermal reservoir have been developed by different investigators, and these models are in general agreement with one another. A generalized model based on these concepts is illustrated in figure 11. Faust and others (1984) and Goff and others (1985) proposed that the mountains within the caldera, those that form its rim, and the moat valleys of the caldera are recharge areas for the geothermal reservoir. Vuataz and Goff (1986) similarly proposed that the entire 14- to 18mile-diameter caldera depression and surrounding highlands serve as the recharge area to the geothermal reservoir, and further, that the moat valleys of Valle San Antonio, Valle Toledo, and Valle Grande, in the north and east areas of the caldera (fig. 6), are probably the principal recharge zones of the reservoir because of their large areal extent, accumulations of sediment, and the streams draining most of the highland areas that flow into these valleys. Based on the deuterium content of water from five Baca wells, the average recharge altitude of the geothermal reservoir is between 8,300 and 9,480 ft (Vuataz and Goff, 1986), which is in good agreement with altitudes in the caldera. Altitudes of caldera valleys range from $7,875 \mathrm{ft}$ in the southwest to about $8,800 \mathrm{ft}$ in the northeast and along the caldera rim exceed 10,000 ft; Redondo Peak reaches 11,254 ft.

The isotopic content of water from wells in the Redondo Creek subsystem indicates two different types of water, suggesting that different areas recharge different parts of the reservoir. Water from Baca wells 4 and 13 is isotopically lighter (larger negative values) than water from Baca wells 15, 19, and 24 (fig. 14). The deuterium content of water from Baca wells 4 and 13 is similar to that of water in Redondo Creek-about -90 and -85 per mil. The similarity in deuterium content of the reservoir and creek water, the proximity of wells and the creek, and the estimated recharge altitude of reservoir water suggest that the source of recharge for water from wells 4 and 13 is the Redondo Peak area (White, 1986). The heavier deuterium content of water from Baca wells 15, 19, and 24 may represent a lower source of recharge for this water, possibly the valley areas of the caldera, or the heavier deuterium content of the water could result from fractionation during boiling or from mixing with other water, such as that occupying the deeper Precambrian rocks. Further discussion of the origin of the two types of water in the Redondo Creek subsystem can be found in Smith and
Kennedy (1985), Truesdell and Janik (1986), and White (1986).

Specific flow paths of recharge water and water within the Valles Caldera geothermal reservoir have not been precisely defined. Cooler recharge water probably flows downward around the outer edges of the reservoir or along the caldera ring fractures, enters the reservoir at depth, is heated, and then rises convectively within the reservoir (Faust and others, 1984). Some ground water in the perched aquifers probably recharges the geothermal system by downward leakage through relatively impermeable welded tuff and the reservoir caprock. However, the amount of downward flow through the tuff and caprock is probably inadequate to be the primary source of recharge to the reservoir. Instead, downward flow along fault zones and fractures is probably the primary mechanism of recharge to the reservoir. As indicated above, much of the water recharging the geothermal reservoir probably does not come from areas directly above and immediately surrounding the reservoir, but reaches the reservoir by lateral flow.

Temperature gradients in the geothermal reservoir area provide insight into possible flow paths of recharge to the reservoir. The shallow temperature gradients (fig. 10) decrease sharply to the southeast between the faults that form the Redondo Creek Graben; deep ground-water temperature contours at about 3,280 ft above sea level exhibit a similar pattern in the reservoir (Wilt and Vonder Harr, 1986, fig. 4). These temperature patterns suggest the inflow of cooler recharge water from the southeast downward along the fault zone that borders the Redondo Creek Graben to the east (Bodvarsson and others, 1982).

Well temperature and pressure information also indicate that within the Redondo Creek reservoir, thermal water generally flows upward and then laterally toward the southwest. Reservoir temperatures generally increase toward the north within the Redondo Creek area and toward the northern part of the Sulphur Creek area (Baca wells 7 and 8). Measured temperatures in the liquid-dominated zone penetrated by wells VC-2A and VC-2B (about $200^{\circ} \mathrm{C}$ ) are lower than those in Redondo Creek area wells and Baca wells 7 and $8\left(250\right.$ to $\left.300^{\circ} \mathrm{C}\right)$. Grant and others (1984) suggested that heated fluids rise under the northern part of the Sulphur Springs area and flow laterally toward the Redondo Creek area. Swanberg (1983) suggested that available well-temperature information was consistent with two zones of convective upflow, one at 
the head of Redondo Creek and bounded by faults of the Redondo Creek Graben and the other bounded by graben faults in the Sulphur Creek area. Grant and others (1984) also argued for a hydrologic connection between these two areas based on similar pressures in Baca wells 7 and 9 and those in Redondo Creek area wells. However, thermal and chemical data for the more recently drilled CSDP wells and well WC23-4 located west of well VC-2A appear to favor a separate flow system within the more southerly parts of the Sulphur Creek area and the ring-fracture zone to the west.

Grant and others (1984) showed that pressure measurements in Baca wells 7 and 8 and Redondo Creek area wells define a consistent gradient within the reservoir that corresponds to a hydrostatic gradient at about $260^{\circ} \mathrm{C}$. This indicates that reservoir fluid moves through the Redondo Creek reservoir in permeability channels as natural flow within the reservoir. The pressure gradient also indicates upward flow in regions where temperatures exceed $260^{\circ} \mathrm{C}$ and the nominal potentiometric surface of the reservoir (the altitude at which the pressure gradient extrapolates to atmospheric pressure) is about $7,900 \mathrm{ft}$ above sea level or $1,100 \mathrm{ft}$ below a land-surface altitude of $9,000 \mathrm{ft}$.

Thermal water discharges laterally from the geothermal reservoir toward the southwest where Cañon de San Diego intersects the rim of the caldera. Such discharge from a geothermal reservoir is commonly referred to as a hydrothermal outflow plume. A plume from the Valles Caldera had been postulated by various investigators. Dondanville (1971) first proposed that the hot springs in Cañon de San Diego represent outflow from the geothermal reservoir in the caldera. Before Dondanville's report was released in 1978, Trainer (1974) independently recognized that the chemistry of two groups of hot springs along the Jemez Fault Zone in Cañon de San Diego was similar to that of deep geothermal fluids within the caldera and proposed that these springs were caused by subsurface discharge from the geothermal reservoir. Goff and others (1981) added further support to this idea, and included geologic, chemical, and isotopic evidence. CSDP core hole VC-1 (fig. 5), drilled in 1984, intersected the hydrothermal discharge plume in the Madera Limestone at a depth of about $1,575 \mathrm{ft}$ (Goff and others, 1988). The hole was drilled in the southwest moat near the intersection of the ringfracture zone and the Jemez Fault Zone (fig. 5), which is approximately midway between the geothermal reservoir and the hot springs in Cañon de San Diego. The discharge plume from the Valles Caldera was described in detail by Goff and others (1988). They considered stratigraphic, temperature-gradient, and hydrogeochemical data to define the configuration and chemical characteristics of reservoir discharge. The following description of the discharge plume draws primarily from their work.

Discharge of thermal water from the caldera comes from at least two subsystems, Redondo Creek and Sulphur Springs. On the basis of estimated discharge rates, thermal gradients, heat flow estimates, and geochemical mixing relations, Goff and others (1988) estimated that about 25-50 percent of the discharge plume is channeled along vertical conduits in the Jemez Fault Zone where it intersects the caldera. The fault zone, which conducts a large portion of the flow, constitutes no more than 10 percent of the area affected by the discharge. The remainder of the discharge is assumed to be distributed for about 6,500 $\mathrm{ft}$ on either side of the fault zone and contained primarily in horizontal, semipermeable Paleozoic strata above the contact with Precambrian crystalline rocks. The lateral extent of discharge from the geothermal reservoir has not been fully defined.

Goff and others (1988) assumed, on the basis of proximity alone, that the Redondo Creek subsystem contributes most of the thermal water to the Jemez Fault Zone and that the Sulphur Springs subsystem contributes the thermal water flowing under the Jemez Plateau west of the caldera. The thermal water mixes with dilute nonthermal water as it moves laterally away from the reservoir. On the basis of this assumption and on geochemical data, Goff and others (1988) calculated that water of the discharge plume, where sampled by CSDP hole VC-1, is composed of approximately 30 percent geothermal water from the Redondo Creek subsystem and that the discharge plume flowing under the Jemez Plateau could be composed of as little as 1525 percent geothermal water from the Sulphur Creek subsystem. Grant and others (1984) suggested that thermal waters from the Sulphur Springs subsystem flow toward the Redondo Creek subsystem and then down Cañon de San Diego. However, analysis of data for wells in the Jemez Plateau area west of the caldera, discussed in the next section, suggests otherwise.

The total rate of thermal-water discharge from the Valles geothermal system is difficult to determine because most shallow discharge of thermal water 
occurs as diffuse seepage into streams. Thermal water from the Valles Caldera outflow plume can be identified in hot springs at Soda Dam and Jemez Springs (H-6 and VA-10, respectively, fig. 5) in Cañon de San Diego and in various wells drilled adjacent to the southern and western edges of the caldera. The model of Faust and others (1984) simulated predevelopment conditions in the geothermal system with an input of approximately 2,030 acre-ft/yr of hightemperature water at the base of the geothermal reservoir. In their model, 1,300 acre- $\mathrm{ft} / \mathrm{yr}$ of this inflow moves through the system and eventually discharges into the Jemez River. This value is between other estimates, which are based on chemical flux measurements, of input of Valles-type thermal water to the Jemez River of 715 acre-ft/yr upstream from San Ysidro (fig. 1) and 2,550 acre-ft/yr at its confluence with the Rio Grande. These estimates may include contributions of mineralized water from the stream draining the Nacimiento Mountains west of Cañon de San Diego (fig. 1). This subject is discussed further in following sections.

\section{SOUTHWESTERN JEMEZ MOUNTAINS}

Hydrothermal features in the Jemez Mountains outside the Valles Caldera are restricted to the southwestern part of the region and largely to a specific part of it, Cañon de San Diego. Fumaroles and thermal mineral springs in the canyon indicate subsurface drainage of geothermal fluid from the caldera. Until the onset of research activity in Valles Caldera beginning in the 1970's, the thermal springs in Cañon de San Diego (at Jemez Springs and Soda Dam in fig. 1) were the best known geothermal features in the Jemez Mountains. They had been used by pueblo Indians who lived in the canyon before the Spanish came to New Mexico, were observed by expeditions sent through the Southwest by the U.S. Government, and were in part later developed for bathing. After settlement of the village of Jemez Springs at least two bathhouses were built and maintained, and the village became a popular resort. Water samples from Jemez Springs were chemically analyzed as early as 1875 (Summers, 1976, p. 38). Several drill holes outside the canyon have penetrated mineral water that contains a component of geothermal-reservoir fluid; no other evidence of such fluid has been found elsewhere in the Jemez Mountains.
The southwestern Jemez Mountains region (fig. 1) extends west and south from Valles Caldera to the San Pedro Mountains and the Nacimiento Mountains, south to the village of San Ysidro, and southeast to the Rio Grande north of Bernalillo. It includes the western marginal fault zone of the Rio Grande Rift. North of Jemez Pueblo, the fault zone is entirely in consolidated rocks, which extend into the rift; south of the pueblo, the fault zone separates tuff and sedimentary and crystalline rocks outside the rift from thick basin-fill deposits and volcanic rock within it. The fault zone is complex and is composed of two or more major faults that extend southward across the region.

Between the caldera and the villages of Ponderosa and Cañon (fig. 1), the topography consists of long, narrow mesas capped by Bandelier Tuff and of intervening canyons cut into the underlying sedimentary rocks. Farther south erosion has largely removed the tuff, and irregular topography has developed on valley-fill deposits and consolidated rocks. The major valleys are Cañon de San Diego, which breaches the rim of the caldera and extends as a narrow canyon to the vicinity of Cañon, then southward to San Ysidro as a wide valley, and the canyons of the Rio Cebolla and Rio Guadalupe, west and southwest of the caldera. The Rio Guadalupe joins the Jemez River near Cañon. The Jemez River flows into the Rio Grande near Bernalillo.

The rocks exposed over most of the southwestern Jemez Mountains region are consolidated rocks of late Paleozoic age (table 1, Jemez Plateau column): limestone and subordinate sandstone of the Carboniferous Sandia Formation and Madera Limestone and sandstone, siltstone, and subordinate limestone in the Permian Abo, Yeso, and San Andres Formations. This section unconformably overlies Precambrian granitic and gneissic crystalline rocks, which outcrop only locally in this region but are exposed over considerable areas in the Nacimiento Mountains to the west. Deep wells outside the western rim of the caldera penetrate the crystalline rocks about 2,100 to $2,400 \mathrm{ft}$ beneath the surface of the plateau. Near the southern edge of the region, at and east of Jemez Pueblo, the consolidated rocks are overlain by sandy, Tertiary rift-fill deposits (Zia Sand and Santa Fe Group) (table 1, Rio Grande Rift column), which are, at places, overlain by or intercalated with Tertiary volcanic rocks. The Pleistocene Bandelier Tuff rests unconformably on the old sedimentary rocks throughout the northern part of this region, extending 
south to the Cañon area. Post-Bandelier Tuff volcanic rocks of several eruptive episodes were emplaced in and near the ring-fracture zone; one flow extended into Cañon de San Diego near the rim of the caldera.

Near the caldera, the surface of the crystalline rocks and overlying sedimentary strata dip gently south and southwest. In Cañon de San Diego, upstream from Jemez Springs, the gradient of the valley floor is greater than the dip of the strata, so a northward (up canyon) traverse rises through the stratigraphic section. The canyon cuts into Carboniferous rocks from Jemez Springs to near the confluence of the East Fork Jemez River and Jemez River (fig. 5), into Permian rocks to the vicinity of Spence Spring (H-42, fig. 5), and beyond that into volcanic rocks. Southward from Jemez Springs, through a slight change in dip of the strata, the Permian rocks are at the surface as far south as Jemez Pueblo; the Carboniferous rocks are exposed only in eroded folds and fault blocks northwest and west of Cañon and Jemez Pueblo. This areal distribution of Carboniferous limestones may control the distribution of mineral springs in and near Cañon de San Diego. So far as is known, the Valles Caldera discharge plume is present only in and near the limestone.

Faults in the southwestern Jemez Mountains are concealed throughout much of their extent. They are undoubtedly more numerous, and their pattern more complex, than indicated by figures 2 and 5 .

Numerous investigators have noted the significance of the marginal fault zone along the west side of the Rio Grande Rift in the Jemez Mountains to the flow of geothermal fluid out of Valles Caldera, in particular Goff and others (1988). Near Soda Dam, mapping of the Jemez Fault Zone and travertine deposits cut by it was updated by Goff and Kron (1980). Subsequent study of these travertine deposits using uranium-thorium dating and stable-isotope analyses (Goff and Shevenell, 1987) has documented the million-year history of the hydrothermal system in the Valles Caldera.

Not until the 1970's was a connection drawn between the thermal mineral waters in Cañon de San Diego and the geothermal reservoir in Valles Caldera. Dondanville (1971) pointed to general geologic relations and chemical similarity between these springs and geothermal fluid and drew the first credible inference of a caldera source for the mineral-spring waters. Woltz (1972) concluded from study of selected chemical constituents that the water, as well as other water in the region, contains contributions from magmatic sources. Earlier work by White and others (1963, p. 42) had shown the water at Jemez Springs to be typical of thermal water in non-geyser areas associated with volcanism, and Trainer (1974) used their characterization of major and minor constituents to argue a caldera source for the spring water. Additional critical information provided by other investigations reinforced the hypothesis of a caldera connection. Deep drilling by the LANL-well GT- 2 at the LANL hot-dry-rock site just outside the western rim of the caldera (fig. 5)-found mineralized water in the basal limestone and in fractures in the upper part of the underlying gneiss (Pettitt, 1975a, p. 7; Trainer, 1978, table 5, well N4). Based on the chemical composition and calculated temperature, the water from this well appeared to have come from the caldera. Hydrochemical data for deep wells in the caldera had not been released at that time, but Trainer (1975) assumed that the water from the LANL well represented a geothermal-fluid end member mixed with native, nonthermal ground water. Trainer used a simple mass-balance calculation to show that the mineral-spring water could be explained by such mixing.

Further support for the concept of the escape of geothermal fluid from the caldera came from three additional investigations. Two surface-geophysical studies, in the ring-fracture zone near the head of Cañon de San Diego (Jiracek, 1974; Jiracek and others, 1975) and in the canyon near Jemez Springs (Pearson and Goff, 1981), detected low resistivity and thus the suggestion of mineralized water. Finally, CSDP test hole VC-1 (fig. 5) penetrated several conduits containing thermal water, and cores revealed extensive alteration and mineralization of the country rock, which indicate that flow in the past occurred at temperatures higher than those of the present (Goff and others, 1988). The test hole also provided a wide range of additional information on rock structure and stratigraphy, heat flow, and chemistry and stable isotopes of water and rocks.

Further information came from test holes drilled by the Village of Jemez Springs and by the USGS. The village well was drilled in 1979 to explore the potential for development of hot water for space heating. Data from the well (Goff and others, 1981), together with results of the surface resistivity soundings in the canyon floor (Pearson and Goff, 1981), represent the only geothermal information, other than chemical and isotopic analyses, for a site this far south in Cañon de 
San Diego. A significant result of this work at Jemez Springs was an emphasis on the differences between the mineral water at Jemez Springs and Soda Dam; Goff and others (1981, p. 241) and Trainer (1984, p. 255 ) concluded that flow and mixing must occur in more than one system of conduits in the Jemez Fault Zone. White and others $(1984$, p. 262) argued the same point on the basis of water chemistry.

Thermal and cold mineral water west and northwest of San Ysidro, near and along the west front of the Nacimiento Mountains, resembles the Valles Caldera hot mineral fluid in terms of major chemical constituents, except for large concentrations of sulfate; on this basis Trainer $(1974,1975)$ thought that the thermal and cold mineral water might be mixed water derived in part from the caldera. Subsequent study of additional chemical analyses and stable-isotope data has shown the water to be unrelated to the Valles geothermal system (Goff and others, 1981, p. 241; Vuataz and Goff, 1986, p. 1843; Shevenell and others, 1987 , p. 22-25). This new interpretation raised the question of how far Valles-derived geothermal fluid travels through the Cañon de San Diego.

\section{Descriptive Hydrochemistry}

Ground-water information for the southwestern Jemez Mountains region is limited; the region is rugged and semiarid, sparsely settled, and has few wells and developed springs. To some degree these obstacles to interpretation are offset by the distinctive geochemical character of the ground water, which aids in identification of the sources and evolution. Because chemical data provide a chief means of hydrologic investigation, the interpretive discussion begins with a brief description of the chemical characteristics of ground water in the region. Subsequent sections of the report consider (1) the mixing of mineralized water, with its implications for human use of ground water and (2) the nature of the ground-water system in the southwestern Jemez Mountains.

The major-ion composition of five samples thought to represent geothermal reservoir fluid in the Valles Caldera is shown in figure 15A. The fluid is a $\mathrm{Na}$ $\mathrm{Cl}$ water whose chloride content (fig. 15B) is about 50 to 100 milliequivalents per liter $(\mathrm{meq} / \mathrm{L}$ ) or 1,800 to $4,000 \mathrm{mg} / \mathrm{L}$. Minor constituents in samples from Baca wells 4,13 , and 24 include As (1.3 to $2.3 \mathrm{mg} / \mathrm{L}$ ), B (16 to $29.6 \mathrm{mg} / \mathrm{L}$ ), $\mathrm{Br}$ (3.6 to $13.6 \mathrm{mg} / \mathrm{L}$ ), and $\mathrm{Li}$ (15 to 32.8 $\mathrm{mg} / \mathrm{L})$.
The major ions in ground water in granitic and volcanic rocks in this area and in alluvium and colluvium derived from the volcanic rocks are summarized in figure 16. The grouping of data in figure $16 \mathrm{~A}$ represents a range of compositions from $\mathrm{Na} \mathrm{Ca}$ $\mathrm{HCO}_{3}$ water derived from the dissolution of $\mathrm{Na}$ - and Ca-rich minerals, such as feldspars, by water from precipitation containing atmospheric and biogenic carbonic acid. Concentrations of major and minor constituents in the ground-water samples are small and their respective flowpaths are believed to have penetrated to only shallow depths before returning to the surface.

Ground water in the Madera Limestone (fig. 17) generally has a $\mathrm{Ca} \mathrm{Mg} \mathrm{HCO}$ composition typical of water in carbonate rocks. Composition of water samples from the Abo Formation (fig. 18) suggests a wide range in lithologies, from calcareous to siliceous sandstone and shale. If a larger number of samples were available, the sample field probably would cover the entire southwestern part of the field, as in the volcanic and related detrital rocks (fig. 16, noted above) and rift-fill sediments (fig. 19).

The principal patterns in figures 15-19 are (1) the conspicuous differences in composition and concentrations of dissolved constituents in geothermal fluid and all other ground water and (2) the lesser but consistent differences between water in carbonate and in igneous rocks. These patterns are useful in interpretation of mixed water.

\section{Mixtures of Water}

Subsurface escape of reservoir fluid from the geothermal system beneath Valles Caldera, southwestward beneath and near Cañon de San Diego, has formed a discharge plume that extends downcanyon at least as far as Soda Dam and Jemez Springs. Study of travertine deposits at Soda Dam (Goff and Shevenell, 1987) has shown that subsurface discharge was active during much or all of the millionyear history of the caldera. Analytical data for well VC-1 (fig. 5) (Goff and others, 1988) show that near the caldera rim the plume consists of a mixture of reservoir and nonreservoir fluids. Mass-balance characterization of geothermal fluid mixing with native ground water along its flow path (Trainer, 1975, 1984) indicates mixing in and near Cañon de San Diego. 
(A)

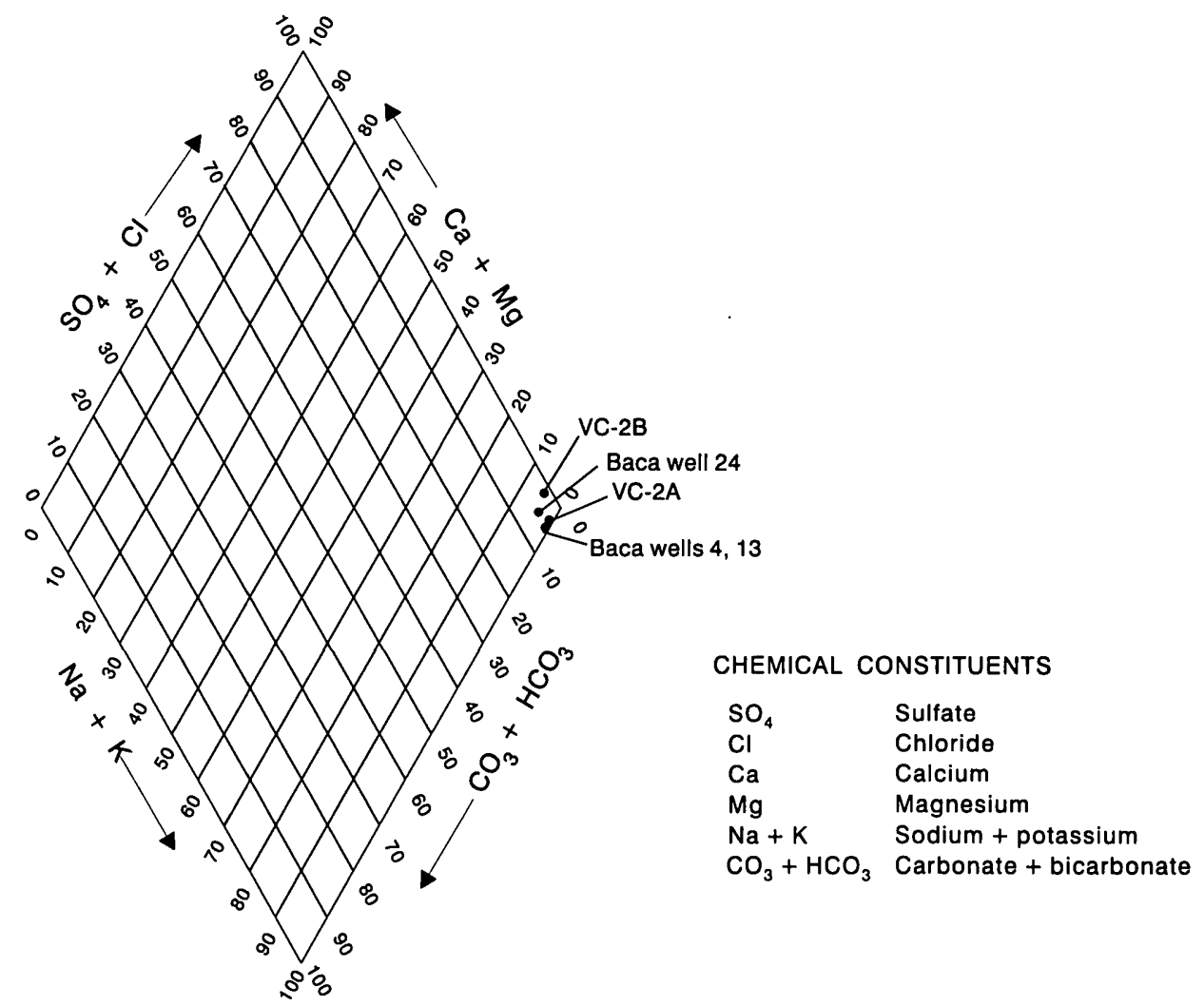

PERCENTAGE OF TOTAL IONS, IN MILLIEQUIVALENTS PER LITER

(B)

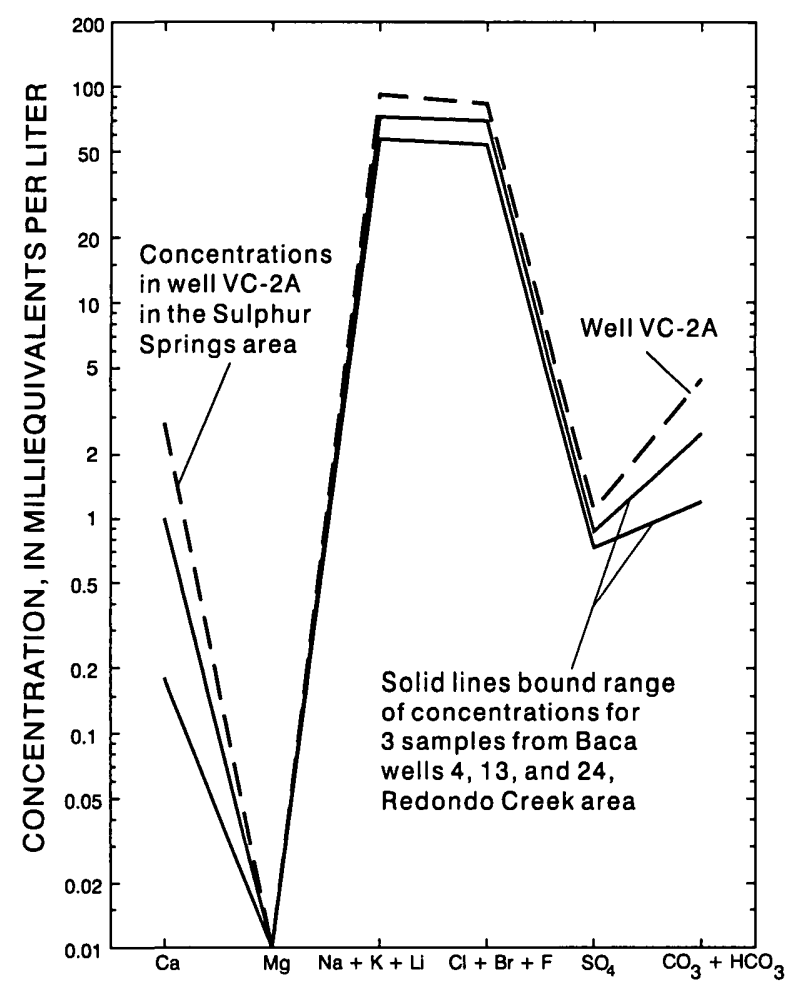

CONSTITUENT

Figure 15.--(A) Major-ion composition and (B) concentrations in water from geothermal wells in the Sulphur Springs and Redondo Creek areas (data from Goff and others, 1992, table 1; and White, 1986, table 1). Well locations shown in figure 5. 
(A)

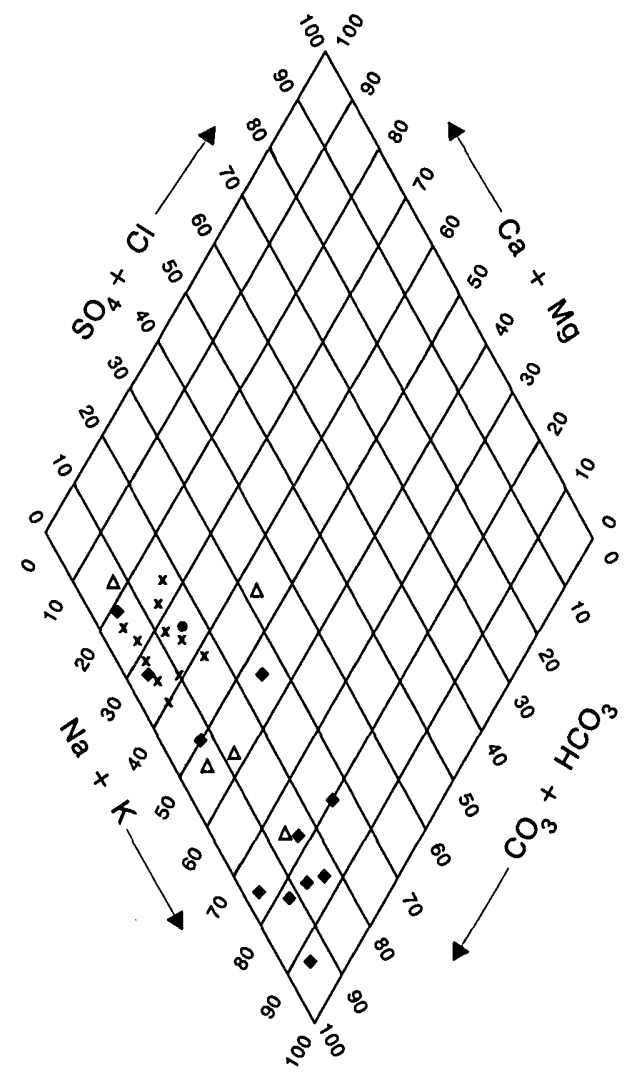

EXPLANATION

- WATER FROM GRANITIC ROCKS

$x$ NONTHERMAL WATER FROM VOLCANIC ROCKS

- WARM WATER FROM VOLCANIC ROCKS

$\triangle$ WATER FROM VOLCANIC ALLUVIUM AND COLLUVIUM

\section{CHEMICAL CONSTITUENTS}

SO. Sulfate

$\mathrm{Cl} \quad$ Chloride

$\mathrm{Ca} \quad$ Calcium

$\mathrm{Mg} \quad$ Magnesium

$\mathrm{Na}+\mathrm{K} \quad$ Sodium + potassium

$\mathrm{CO}_{3}+\mathrm{HCO}_{3}$ Carbonate + bicarbonate

PERCENTAGE OF TOTAL IONS,

IN MILLIEQUIVALENTS PER LITER

(B)

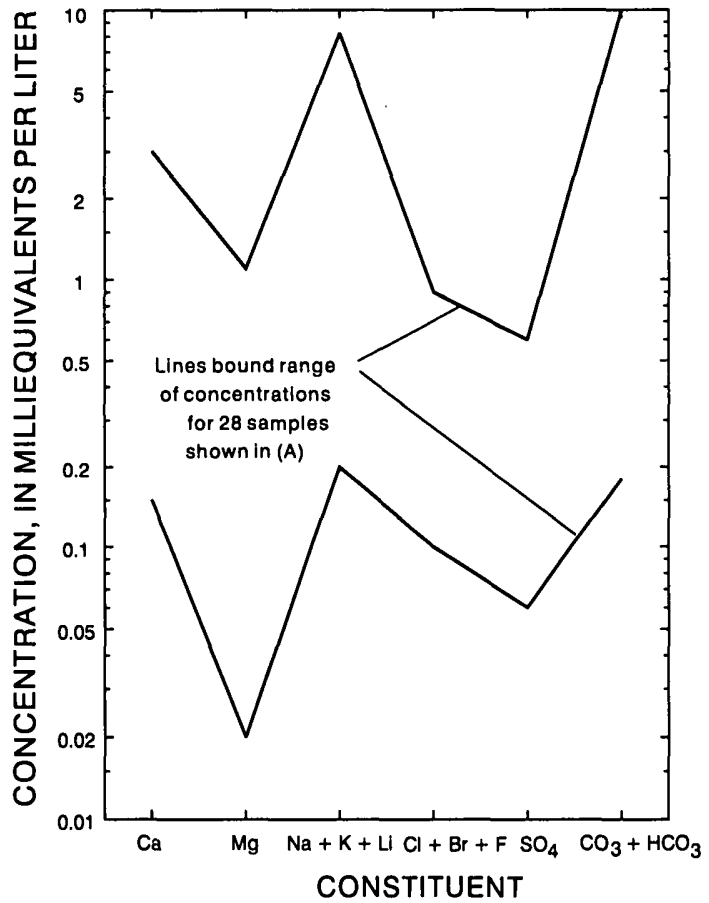

Figure 16.--(A) Major-ion composition and (B) concentrations in water from wells and springs in granitic rocks, volcanic rocks (chiefly rhyolitic and andesitic), and alluvium and colluvium derived from volcanic rocks (data from Purtymun and others, 1974, tables IX and X; Trainer, 1978, table 5; and Shevenell and others, 1987, table B-II). 
(A)

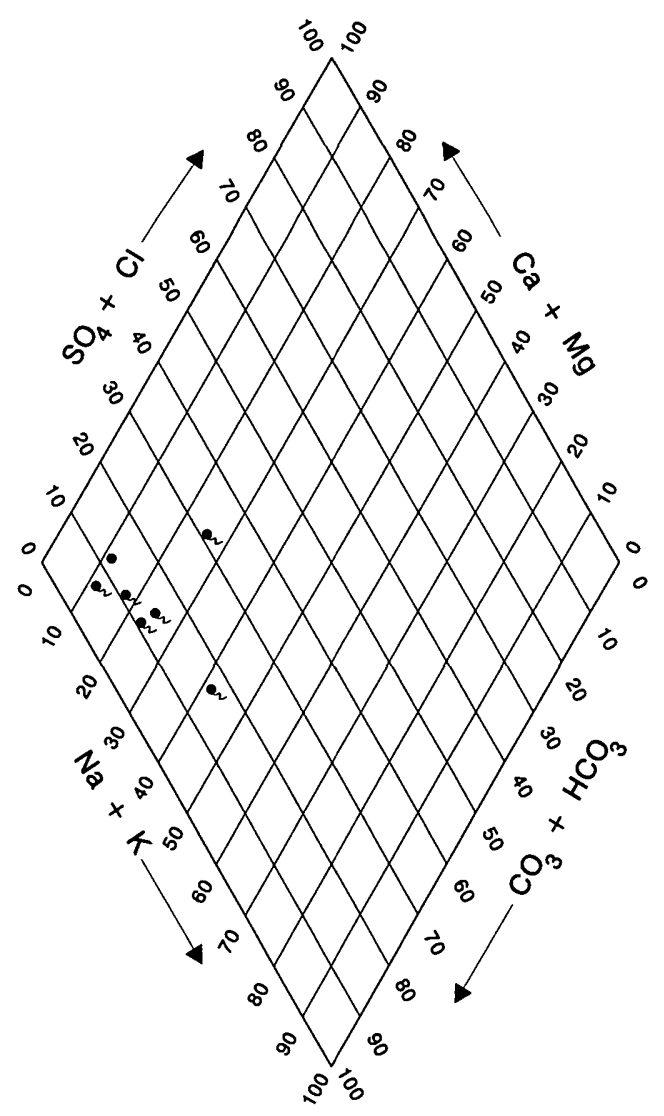

PERCENTAGE OF TOTAL IONS,

IN MILLIEQUIVALENTS PER LITER

(B)

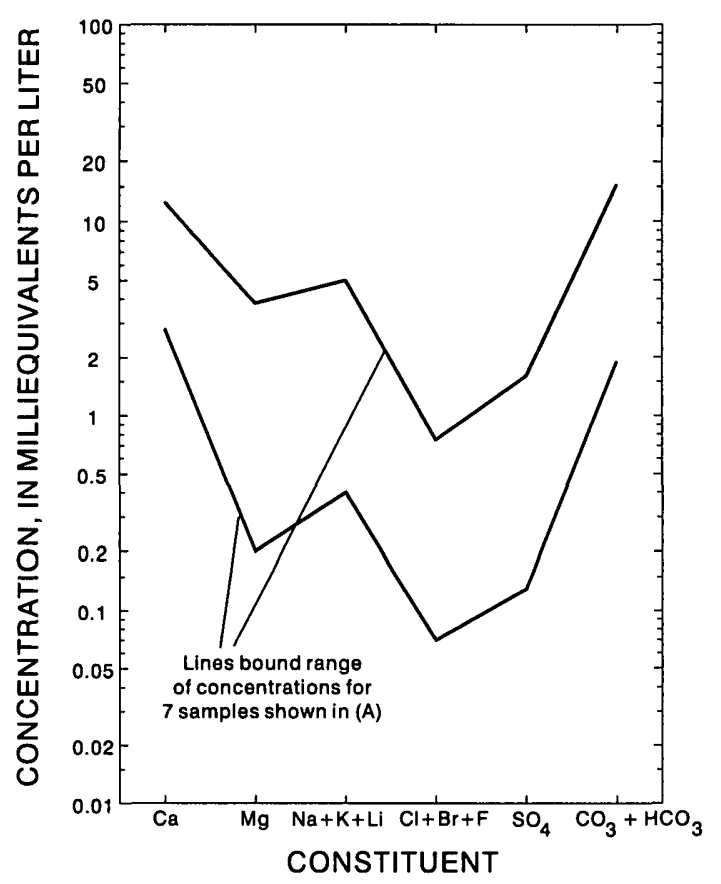

EXPLANATION

- WELL

a SPRING
CHEMICAL CONSTITUENTS

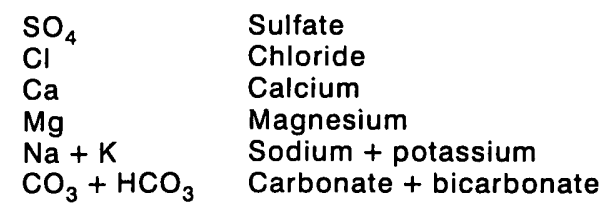

Figure 17.--(A) Major-ion composition and (B) concentrations in water from wells and springs in the Madera Limestone (data from Purtymun and others, 1974, tables IX and X; Trainer, 1978, table 5; and Shevenell and others, 1987, table B-II). 
(A)

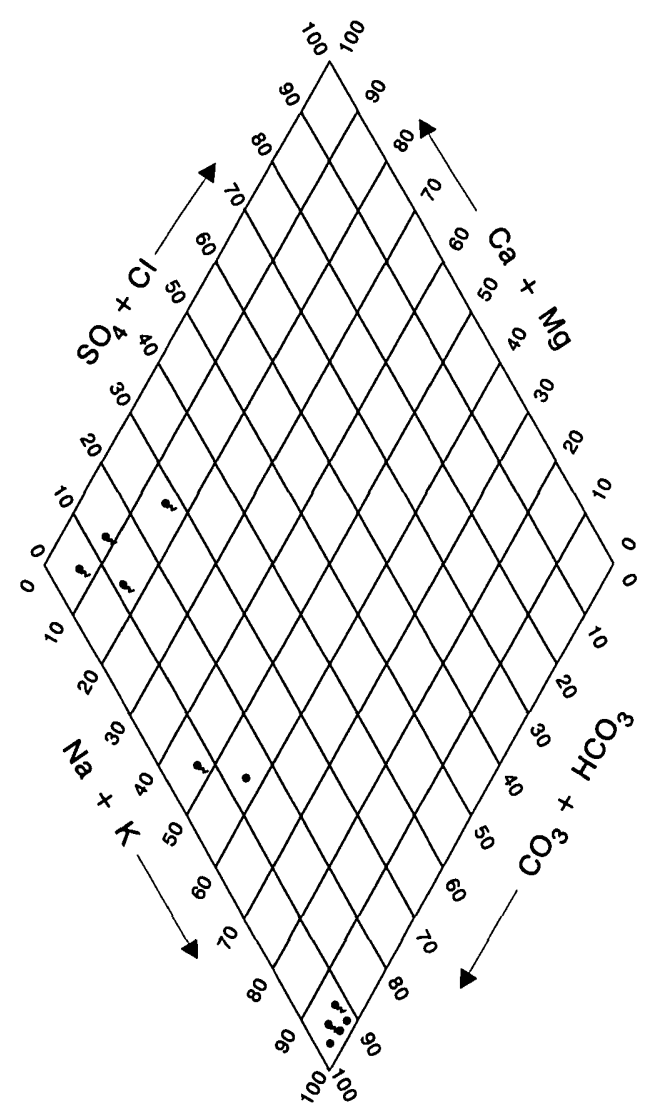

EXPLANATION

- WELL

Q SPRING

CHEMICAL CONSTITUENTS

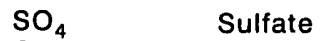

$\mathrm{Cl}^{4} \quad$ Chloride

$\mathrm{Ca} \quad$ Calcium

$\mathrm{Mg} \quad$ Magnesium

$\mathrm{Na}+\mathrm{K} \quad$ Sodium + potassium

$\mathrm{CO}_{3}+\mathrm{HCO}_{3}$ Carbonate + bicarbonate

PERCENTAGE OF TOTAL IONS,

IN MILLIEQUIVALENTS PER LITER

(B)

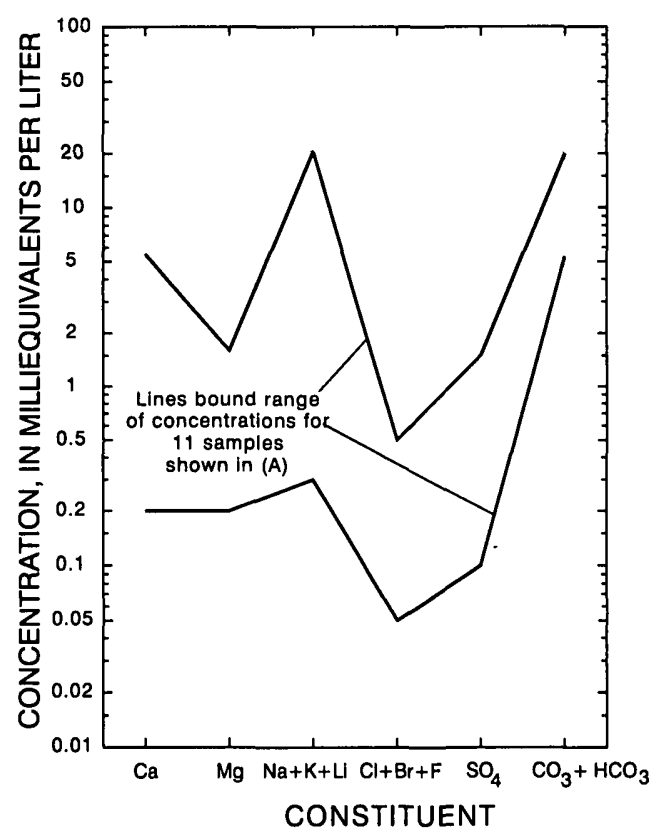

Figure 18.--(A) Major-ion composition and (B) concentrations in water from wells and springs in the Abo Formation (data from Purtymun and others, 1974, tables IX and X; Trainer, 1978, table 5; and Shevenell and others, 1987, table B-II). 
(A)

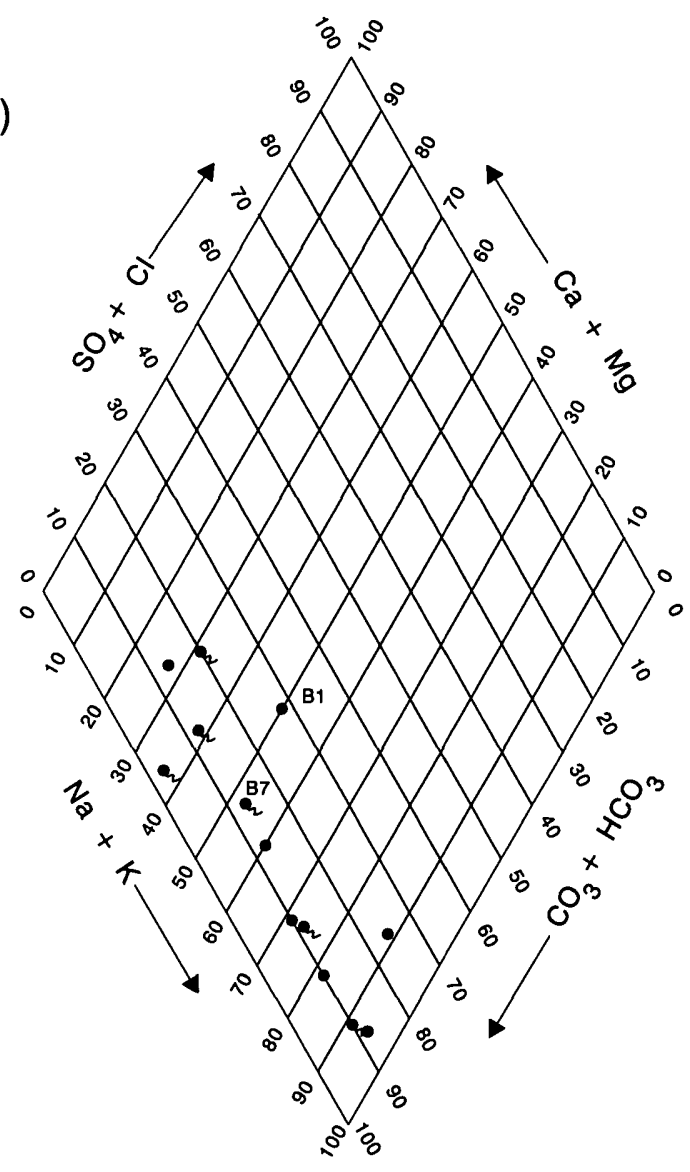

EXPLANATION

a SPRING

- WELL

\section{CHEMICAL CONSTITUENTS}

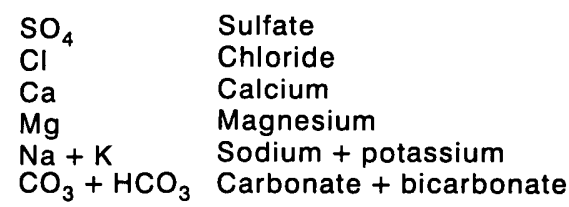

(B)

PERCENTAGE OF TOTAL IONS, IN MILLIEQUIVALENTS PER LITER

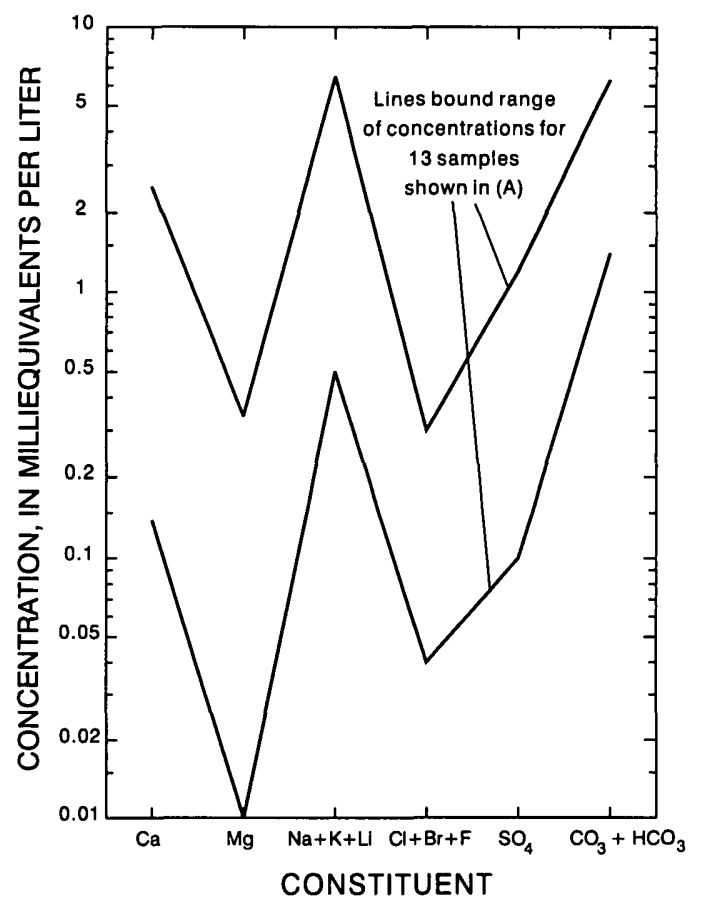

Figure 19.--(A) Major-ion composition and $(B)$ concentrations in water from wells and springs in rift-fill deposits (Santa Fe Group and Zia Sand) (data from John and others, 1967; Trainer, 1978, table 5; and Goff and Sayer, 1980). 
Two modes of transport move geothermal water and its solutes beneath Cañon de San Diego. Flow is primarily in the subsurface, along fracture conduits controlled by rock structure and stratigraphy. Such flow brings mineral water to Soda Dam and Jemez Springs. Although the results of subsurface flow are apparent, the factors controlling its magnitude and areal extent are poorly known because of limited data. Subsurface flow is discussed in subsequent sections of this report.

The second mode is surface transport in the Jemez River downstream from Soda Dam and Jemez Springs, along with associated ground-water underflow in alluvium beneath and beside the stream and in fractured bedrock near the stream that is hydraulically connected with overlying alluvial deposits. Areal changes in major-ion composition of water in the Jemez River system is shown in figure 20. The figure is based on samples collected over a period of years from June to September when the streamflow is largely or entirely base runoff (ground water discharged to the stream).

Samples from the East Fork Jemez River in Valle Grande (site 1 in fig. 20) and from San Antonio Creek (site 2) in Valle Toledo contained less than $3 \mathrm{mg} / \mathrm{L} \mathrm{Cl}$ ( $\mathrm{Cl}$ brought to the region in precipitation) and about
$100 \mathrm{mg} / \mathrm{L}$ dissolved solids. The $\mathrm{Ca} \mathrm{Na} \mathrm{HCO}_{3}$ composition is typical of ground water in volcanic rocks and their detritus. These two streams form the surface drainage of Valles Caldera. Before leaving the caldera, San Antonio Creek receives the flow of creeks draining the Sulphur Springs area, but those streams are so small that they have little effect on water quality in the much larger San Antonio Creek except for the contribution of $\mathrm{SO}_{4}$ and low $\mathrm{pH}$ from one stream. Just downstream from the confluence of San Antonio Creek and the East Fork Jemez River (site 3), the water composition differs only slightly from that in the caldera. To this point the streamflow consists largely of the combined discharge of numerous cold springs and several warm springs that drain volcanic rocks. The dissolved-solids concentration in summer months is about $50 \mathrm{mg} / \mathrm{L}$ and $\mathrm{Cl}$ averages less than $5 \mathrm{mg} / \mathrm{L}$. Summer base runoff is about 10 to $12 \mathrm{ft}^{3} / \mathrm{s}$. Between the confluence and a point just upstream from Soda Dam (site 4) the composition of stream water approaches that of water in limestone (near the left vertex of the diamond field in fig. 20) as a result of inflow from small limestone springs, several of which are represented in figure 17.
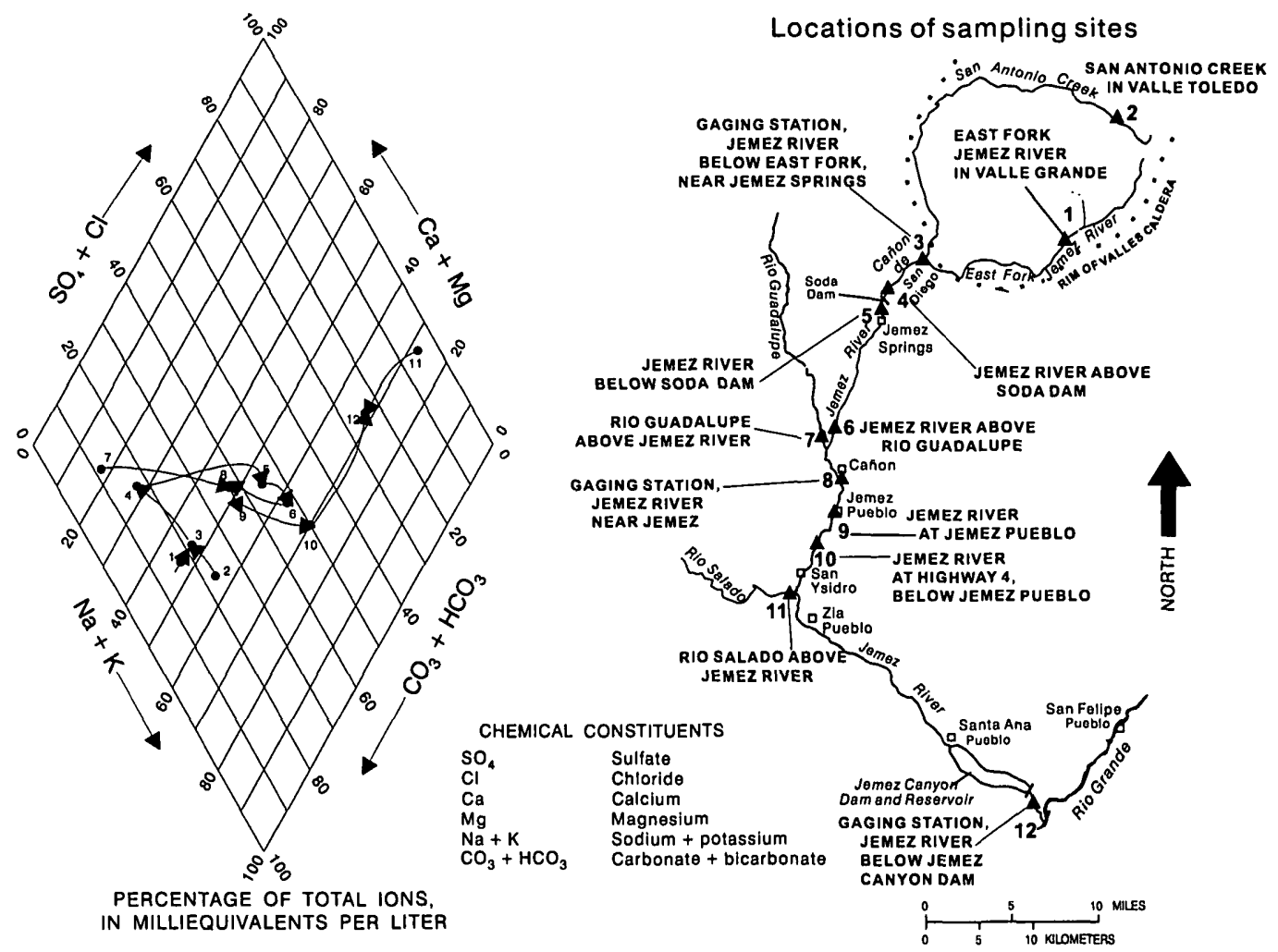

Figure 20.--Downstream change in major-ion composition of water in the Jemez River system and map showing location of sampling sites (data from Trainer, 1978, tables 6 and 11; and files of the U.S. Geological Survey). 
At Soda Dam, about $400 \mathrm{gal} / \mathrm{min}$ of mineralized water containing more than $4,000 \mathrm{mg} / \mathrm{L}$ dissolved solids (Trainer, 1984, based on 1973-74 data) issues from springs. About a quarter of a mile downstream from Soda Dam (site 5), the dissolved-solids concentration of the stream water doubles and its composition approaches the composition of the geothermal fluid (center of the diamond plot, fig. 20). An additional inflow of mineralized water (an estimated $365 \mathrm{gal} / \mathrm{min}$ containing about $2,500 \mathrm{mg} / \mathrm{L}$ dissolved solids) occurs at Jemez Springs. These mineral-spring waters have large concentrations of $\mathrm{Cl}$ and $\mathrm{HCO}_{3}$, which tend to offset each other's effects on the diamond plot.

The Jemez River has an $\mathrm{Na} \mathrm{Ca} \mathrm{HCO}_{3}$ composition and carries about $550 \mathrm{mg} / \mathrm{L}$ dissolved solids and $150 \mathrm{mg} / \mathrm{L} \mathrm{Cl}$ (fig. 20, site 6). The Rio Guadalupe, which drains volcanic and limestone terranes, has a composition dominated by $\mathrm{Ca}$ and $\mathrm{HCO}_{3}$ and carries about $250 \mathrm{mg} / \mathrm{L}$ dissolved solids and less than $10 \mathrm{mg} / \mathrm{L} \mathrm{Cl}$ (fig. 20, site 7). The composition of the combined flows of the streams, as measured at the USGS streamflow-gaging station Jemez River near Jemez (fig. 20, site 8), about $1 \mathrm{mi}$ downstream from the confluence, becomes similar to water in limestone.

With increasing distance downstream from the gaging station, however, at Jemez Pueblo (fig. 20, site 9) and downstream from the pueblo (fig. 20, site 10), Na and $\mathrm{Cl}$ again increase. This change is attributed to the discharge of mineral springs; one well-documented spring discharges directly into the river through its bed and another is known near the river.

Near San Ysidro the Jemez River is joined by the Rio Salado (fig. 20, site 11), which drains the western front of the Nacimiento Mountains near their southern end. The mountains are fault controlled, and numerous mineral springs, active and extinct, occur along the fault zone. Water in the Rio Salado, derived from the Madera Limestone and overlying Mesozoic rocks that are in part gypsiferous, is more highly mineralized (in one September sample, dissolved solids was 11,040 $\mathrm{mg} / \mathrm{L}$ and $\mathrm{Cl}$ was $2,370 \mathrm{mg} / \mathrm{L}$ ) than the Valles geothermal fluid. The Rio Salado channel south of San Ysidro is dry during much of the summer but the flood plain is coated with free salts that are transported with runoff during the next thunderstorm. As a result, and despite the much larger flow of Jemez River, the composition of the combined stream near the southeastern edge of the study area (fig. 20, site 12) shifts significantly toward the right apex of the diamond plot (fig. 20).
The composition of ground water in alluvial deposits (fig. 21) shows a pattern of change similar to that in the Jemez River. Water from volcanic rocks and their detritus (fig. 21, site 1) probably contains a small component derived from the limestone exposed in the nearby canyon. In water from site 2 the limestone influence is more pronounced. Samples from sites 3-6 exhibit the influence of the mineral springs at Soda Dam and Jemez Springs (a pronounced shift to the right in the diamond plot). The scatter at Jemez Pueblo (fig. 21, site 7), indicating local variability in composition, is attributed to a combination of recharge from losing reaches of the stream and mineral-spring discharge into the alluvial aquifer from the underlying bedrock. Additional mineral-water inflow causes changes at sites 8 and 9; the Rio Salado influence (an increase in $\mathrm{Ca}, \mathrm{SO}_{4}$, and $\mathrm{Cl}$ ) is reflected in samples from sites 10 and 11 .

\section{Mineral Water near the Caldera as Derivatives of Geothermal Fluids}

The mineral waters at Jemez Springs and Soda Dam are the most obvious in the southwestern Jemez Mountains. However, mineral water has been penetrated in four wells in the area: well GT-2 (at Fenton Hill); wells PC-1 and PC-2 (near Fenton Hill); and well VC-1 in the ring-fracture zone (fig. 5).

Well GT-2 is one of several deep holes drilled by the LANL on the plateau outside the western rim of the caldera; at the time of its completion at a depth of 6,356 $\mathrm{ft}$, the well was the deepest in the Jemez Mountains outside the caldera. Water was recorded in the lower part of a section of volcanic and sedimentary rocks that totals about $2,400 \mathrm{ft}$. The underlying crystalline rock is of very low permeability except in fractured zones near its upper surface. Water flowing through the deeper levels of the sedimentary rock is inferred, from temperature and chemistry data, to have come from the caldera. Some aspects of water chemistry are obscured by contamination from drilling and grouting fluids.

Five water samples were collected in 1974 during the drilling of well GT-2. Despite contamination from drilling and grouting fluids, the water is similar in chemical composition to mineral water from the Cañon de San Diego area; hence it was used as a hypothetical parent water in development of the hypothesis of mixing of reservoir and nonreservoir water (Trainer, 1975). Subsequent release of analyses of reservoir fluids necessitates re-examination of well GT-2 data. 


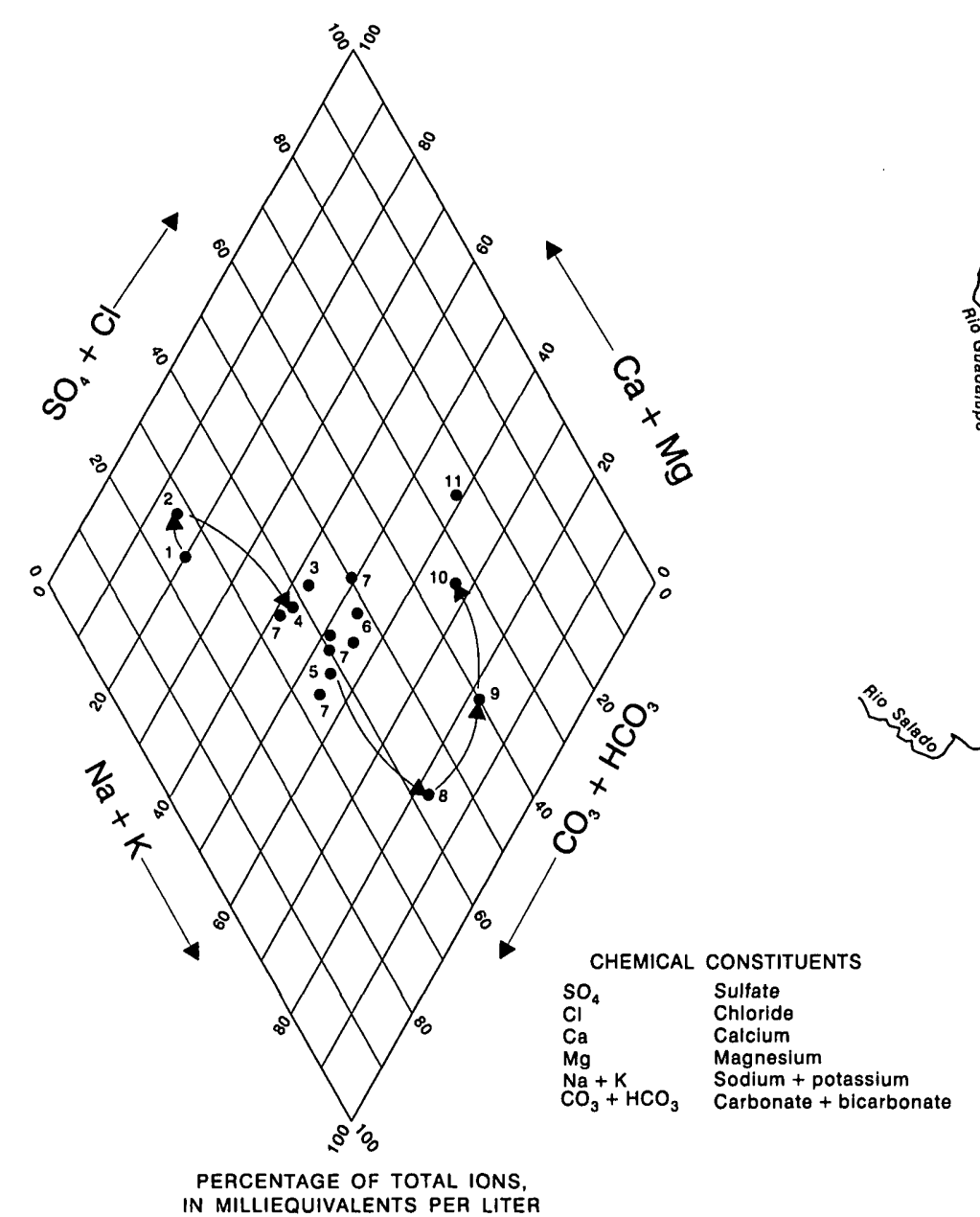

IN MILLIEQUIVALENTS PER LITER

Figure 21.--Major-ion composition in ground water in alluvium along the Jemez River and map showing location of sampling sites (data from Trainer, 1978, tables 6 and 11; and Craigg, 1984, table 3).

Several physical and chemical signatures in ground water are indicative of high-temperature environments. Three signatures in the GT-2 samples suggest a caldera source for the water: a large concentration of dissolved $\mathrm{SiO}_{2}$, indicative of high temperature; large concentrations of several trace constituents typical of hot water in volcanic regions; and a stable-isotope composition similar to those of several reservoir fluids in the caldera. Several trace constituents, expressed as ratios among themselves or with $\mathrm{Na}$ or $\mathrm{Cl}$, have been widely used in geothermal studies, including several in this region. Two trace ions - $\mathrm{B}$ and $\mathrm{Li}$ - are used here in re-examination of the 1974 data. The plots in figure 22 illustrate geochemical similarities among the geothermal-reservoir fluids and the mineral water outside the caldera. Prolonged circulation of hot reservoir fluid has led to accumulation of $\mathrm{Li}, \mathrm{B}, \mathrm{Br}$, and As concentrations far larger than those present outside the caldera where nonthermal water circulates through similar rocks. The ratios of these trace constituents are preserved even when the geothermal fluid becomes diluted. $\mathrm{Li}, \mathrm{B}$, and $\mathrm{Br}$ are conservative tracers; thus, the data points shown in figure 22 approximate straight lines despite the wide ranges in concentration. The major constituent $\mathrm{Cl}$ is commonly used in conjunction with trace ions because only small concentrations of $\mathrm{Cl}$ are present in ground water outside the caldera.

Concentrations of trace constituents in well GT-2 water are unlikely to have been affected by contamination from drilling and grouting fluids; hence, relations such as those shown in figure 22 were used to estimate an original major-constituent analysis of the water. Data from each of several wells in the caldera were used; the concentration of each major constituent (except $F$, for which the analyzed value was accepted) was plotted against a trace constituent (such as $\mathrm{Ca}$ and $\mathrm{B}, \mathrm{Mg}$ and $\mathrm{B}$, and $\mathrm{Cl}$ and $\mathrm{B}$ ) to form a series of curves similar to those in figure 22. The original concentrations of $\mathrm{Ca}, \mathrm{Mg}$, and $\mathrm{Cl}$ were estimated by 

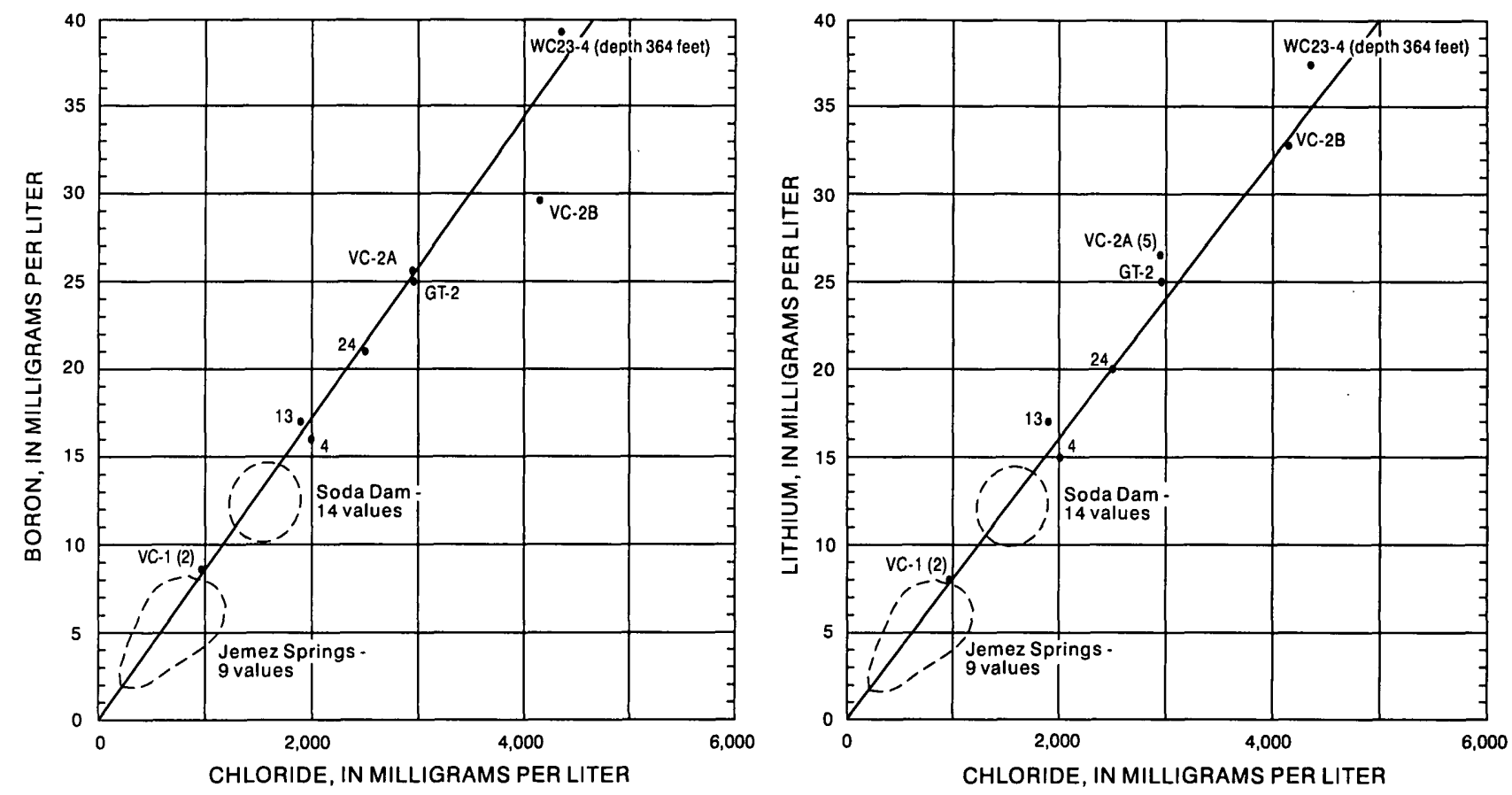

Figure 22.--Concentrations of selected pairs of ions in geothermal-reservoir-fluid samples and in mixed water (data from White, 1986, table 1; Shevenell and others, 1987, table B-II; and Goff and others, 1988, table 2, and 1992, table 1). Numbers in parentheses are number of samples from one well averaged to give plot shown. Well and spring locations shown in figure 5.

using each curve and the $\mathrm{B}$ concentration for GT-2. The entire procedure was done twice, using $\mathrm{B}$ and $\mathrm{Li}$, and the results were averaged to provide the estimated concentrations listed in table 6 . Twenty-five $\mathrm{mg} / \mathrm{L} \mathrm{B}$ (well GT-2) is equivalent to about $2,900 \mathrm{mg} / \mathrm{L} \mathrm{Cl}$ (caldera wells), and $25 \mathrm{mg} / \mathrm{L} \mathrm{Li}$ is equivalent to about $3,010 \mathrm{mg} / \mathrm{L} \mathrm{Cl}$, for an average estimated concentration of $2,955 \mathrm{mg} / \mathrm{L} \mathrm{Cl}$. The sums of cations and anions in this estimated analysis are 95.17 and $89.24 \mathrm{meq} / \mathrm{L}$, respectively - a precision comparable to that of many published analyses for geothermal water in this region. The estimated original concentration for well GT-2 in comparison to analyses of geothermal-reservoir-fluid samples is shown in figure 23.

The estimated original concentrations are an approximation of the original chemistry of the fluid that moved out of the geothermal reservoir and into flow conduits beneath the Jemez Plateau. The effect of any dilution that occurred along the path to well GT-2 is thought to be shown, but the effects of dissolution of wall rock along the flow channels, which cannot be estimated reliably because of contamination from drilling and grouting fluids, are not shown. From the data available, the precise nature of the escaping reservoir fluid is not known. (The reader is referred to Vuataz and Goff (1986, p. 1847) and Goff and others (1988, p. 6047) for a detailed discussion of the difficulties involved in interpretation of sourcereservoir and dilute-mixing fluids.) In general, the escaping geothermal-reservoir fluid is similar to composition and concentrations shown in figure 15. The fluid in well GT-2 is discussed in a later section.

Wells PC-1 and PC-2 penetrated a volcanic and sedimentary section similar to that penetrated by well GT-2, and both passed through numerous perched saturated zones that contain dilute water. Both wells penetrated water-yielding zones in the lower Abo Formation and upper Madera Limestone that yield slightly mineralized water-possible dilute mixtures of native ground water and fluid from a geothermal reservoir. Well $\mathrm{PC}-1$, which extends through the sedimentary rocks and into the underlying gneiss, penetrated several water-yielding zones in the lower part of the limestone that yielded mineralized water. 


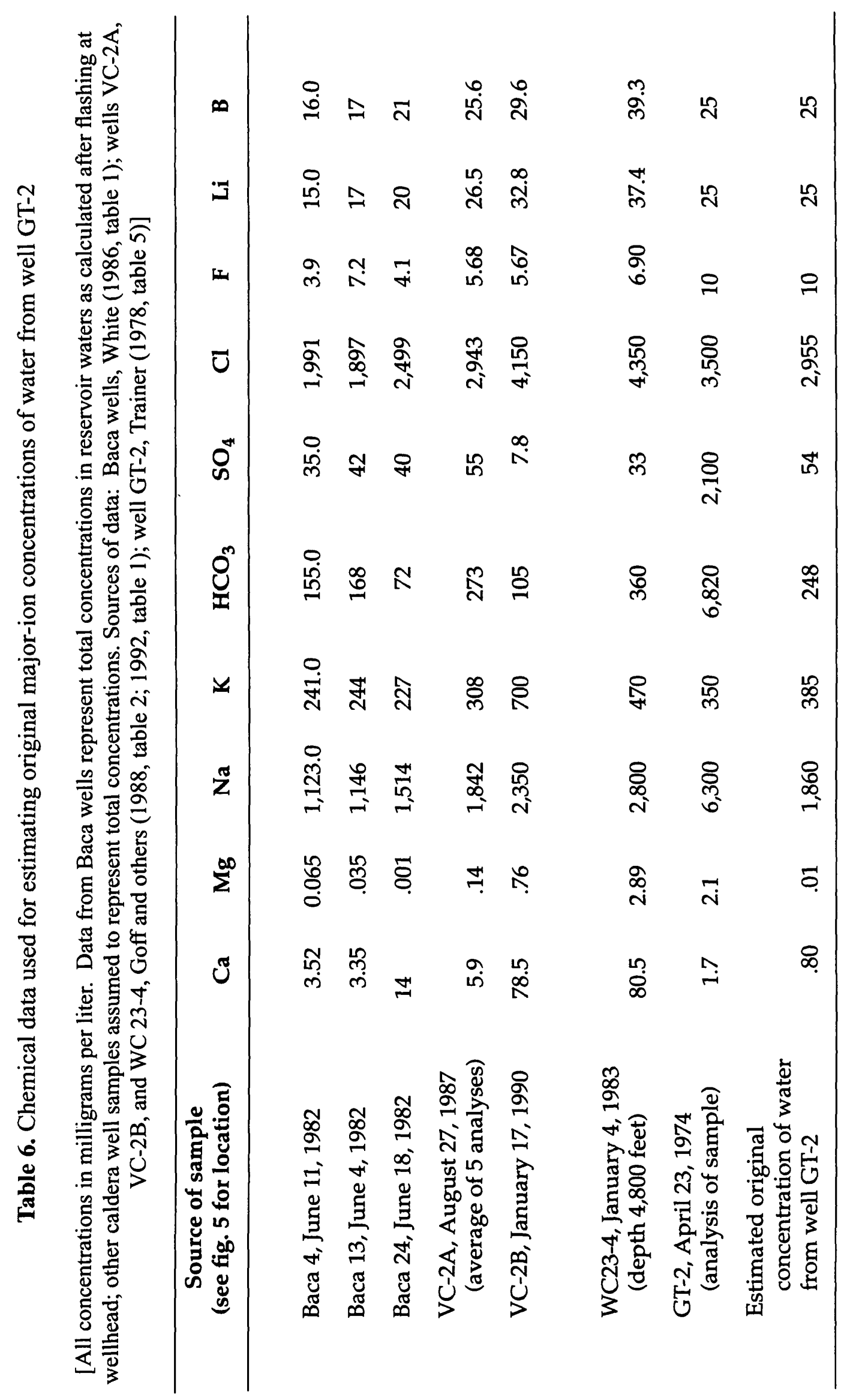




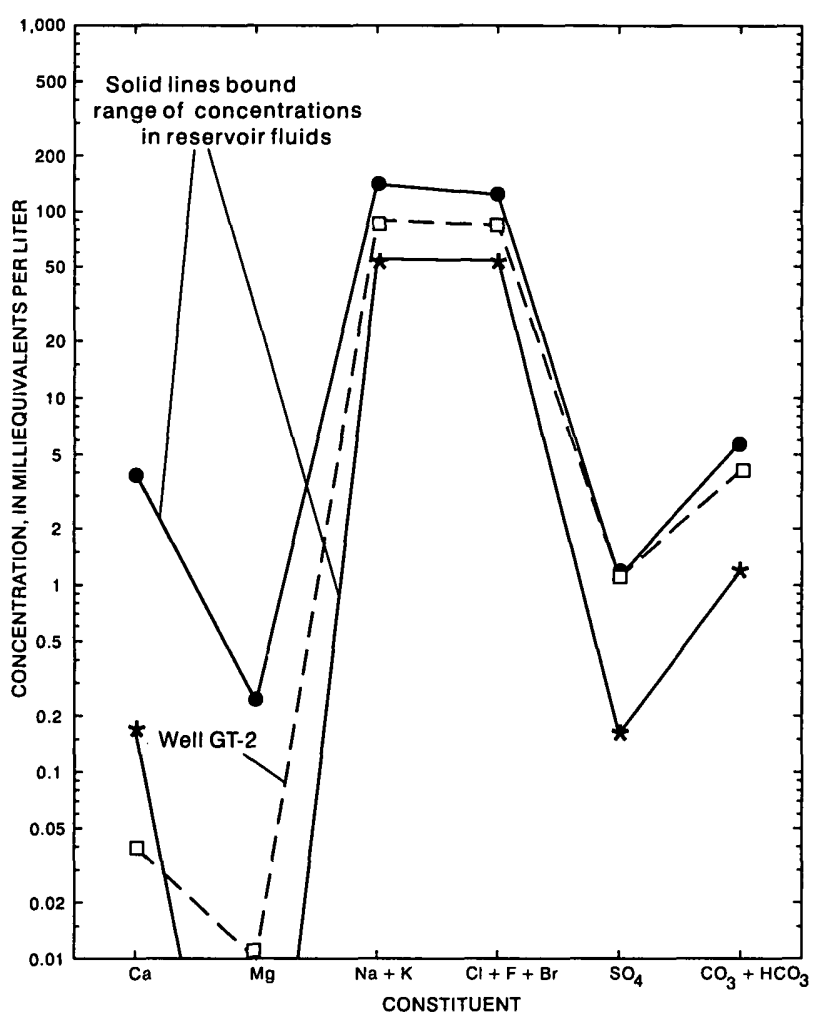

Figure 23.--Major-ion concentrations in geothermal-reservoir-fluid samples and estimated original concentrations in water from well GT-2 (data from table 6). Calcium and magnesium minimum values truncated on graph because they are much smaller than 0.01 milliequivalent per liter. Well location shown in figure 5.

The chemical analyses of water from well PC-1 are presented in table 7 . The last analysis listed was reconstructed and was prepared using the same procedure used for well GT-2. The reconstructed analysis shows only the effect of dilution on the parent geothermal fluid. Comparison of the actual and reconstructed analyses (fig. 24) shows the combined effects of contamination during drilling (probably $\mathrm{Na}_{2} \mathrm{SO}_{4}$ and $\mathrm{CaSO}_{4}$ ) and of dissolution of wall rock, reflected by a-large increase in $\mathrm{Ca}, \mathrm{Mg}, \mathrm{SO}_{4}$, and $\mathrm{HCO}_{3}$.

Well VC-1, in the ring-fracture zone east of Cañon de San Diego and near the Jemez Fault Zone, penetrated the outflow plume from the caldera. The 2,750-ft section of volcanic and sedimentary rocks above the Precambrian crystalline rock contains several thermal-water-yielding horizons in limestone and sandstone (Goff and others, 1988, fig. 4). The reconstructed analysis represents the character of the water if it had been modified from parent reservoir fluid only by dilution. Comparison of the reconstructed analysis of water from well VC-1 (fig. 25) and the actual analysis indicates that the mixed water gained appreciable amounts of $\mathrm{Ca}, \mathrm{Mg}$, and $\mathrm{HCO}_{3}$ through dissolution of wall rock, contribution from local ground water, or both. Well VC-1 was drilled using methods that introduced no significant contamination.

\section{Mineral Water in Cañon de San Diego}

Because sufficient information is available for Cañon de San Diego to show the complexity of the mineral-water chemistry, this section discusses the canyon as a whole. The conceptual model of canyon geohydrology on which the discussion is based is illustrated in figure 26. Diagrammatic geologic section A-A' parallels the general southward trend of Cañon de San Diego and the Jemez Fault Zone. No faults are shown in the canyon except at Soda Dam, where an east-trending fault extends out of the canyon and through the adjacent mesa. The occurrence of mineral springs at Soda Dam and Jemez Springs is fault controlled, but the locations of these springs are also controlled by the relations among the stratigraphic section, canyon floor, rock structure, and potentiometric surface of the regional aquifer. Soda Dam is situated at the lowest point at which its section of the Jemez Fault reaches land surface and at the place where basal beds of the Pennsylvanian limestone and sandstone section are folded upward along the fault. Jemez Springs is near the farthest point downcanyon at which limestone crops out at the surface. 
Table 7. Chemical analyses of water from well PC-1

[Location of well shown in figure 5. PC-1-9, native ground water in perched aquifer in Abo Formation; PC-1-10, Abo Formation; PC-1-11, Madera Limestone, mixed water with small dissolved-solids concentration; PC-1-1, Madera Limestone, mixed water with large dissolved-solids concentration; PC-1-1C, reconstructed analysis.

Analyses from Shevenell and others, 1987, table B-II. --, no data]

\begin{tabular}{lccccccccccc}
\hline & \multicolumn{10}{c}{ Concentration, in milligrams per liter } \\
\cline { 2 - 13 } Sample & $\mathbf{C a}$ & $\mathbf{M g}$ & $\mathrm{Na}$ & $\mathrm{K}$ & $\mathrm{Li}$ & $\mathrm{HCO}_{3}$ & $\mathrm{SO}_{4}$ & $\mathrm{Cl}$ & $\mathrm{F}$ & $\mathrm{Br}$ & $\mathrm{B}$ \\
\hline PC-1-9 & 6.0 & 3.8 & 366 & 6.0 & -- & 852 & 24.5 & 5.0 & 2.15 & - & 0.74 \\
PC-1-10 & 10.3 & 4.2 & 433 & 6.6 & 0.20 & 686 & 151 & 108 & 2.43 & 0.18 & .74 \\
PC-1-11 & 78 & 73 & 740 & 55 & 1.64 & 2,636 & 24.5 & 50 & 6.78 & .29 & 4.24 \\
PC-1-1 & 762 & 52.8 & 1,390 & 153 & 10.8 & 1,133 & 2,157 & 1,602 & 1.06 & 4.3 & 13.4 \\
PC-1-1C & 1.1 & .001 & 850 & 132 & & 124 & 28 & 1,500 & & & \\
\hline
\end{tabular}

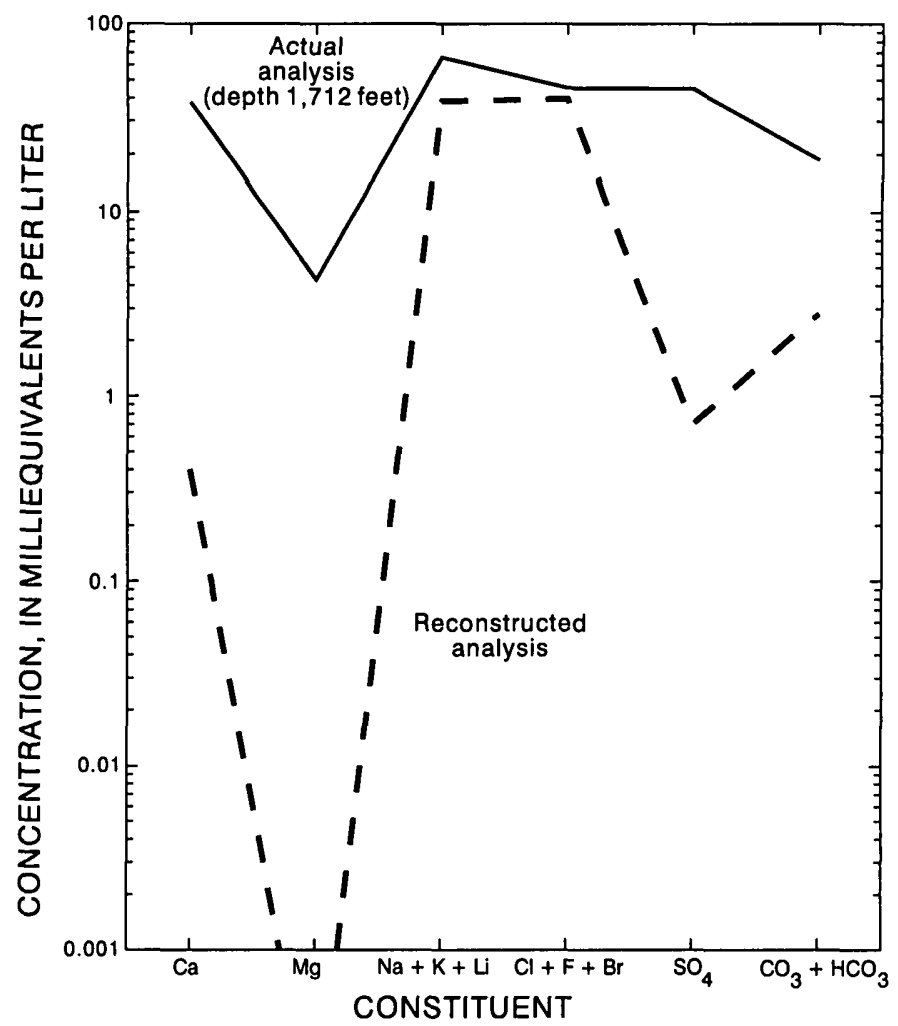

Figure 24.--Actual analysis and reconstructed analysis of major ions in water from well PC-1.

Reconstructed analysis represents character of the water if it had not been contaminated but had been modified from parent reservoir fluid by simple dilution. Reconstructed calcium and magnesium minimum values truncated on graph because they are much smaller than 0.001 milliequivalent per liter. Well location shown in figure 5 . 


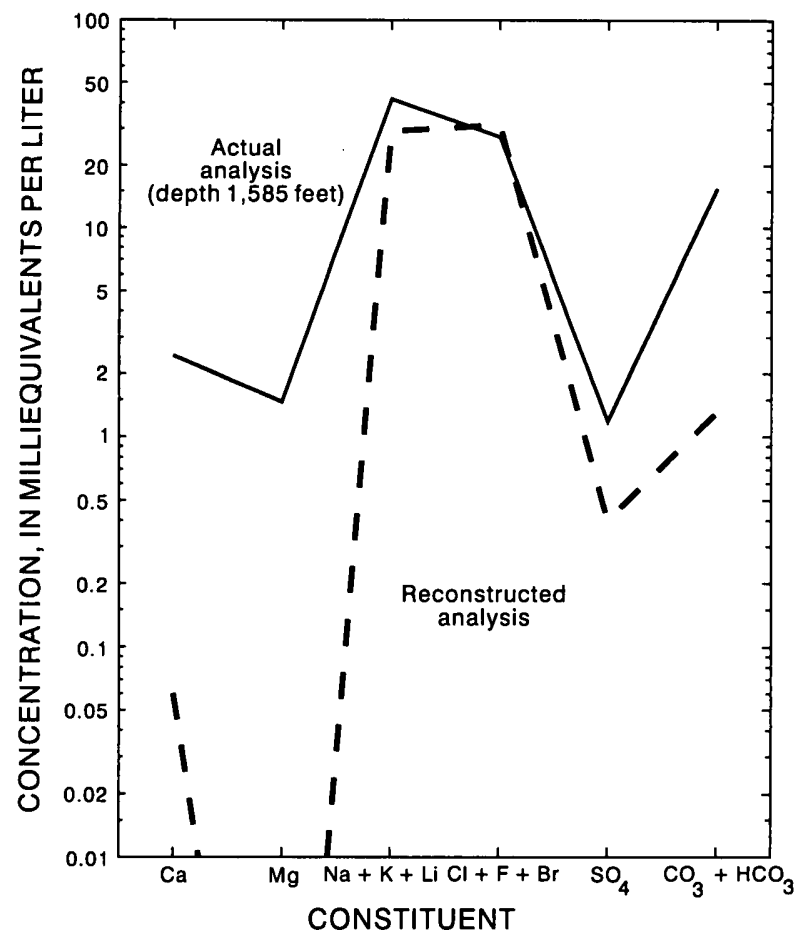

Figure 25.--Actual analysis and reconstructed analysis of major ions in water from well VC-1 (analysis from Goff and others, 1988, table 2). Reconstructed calcium and magnesium minimum values truncated because they are much smaller than 0.01 milliequivalent per liter. Well location shown in figure 5.

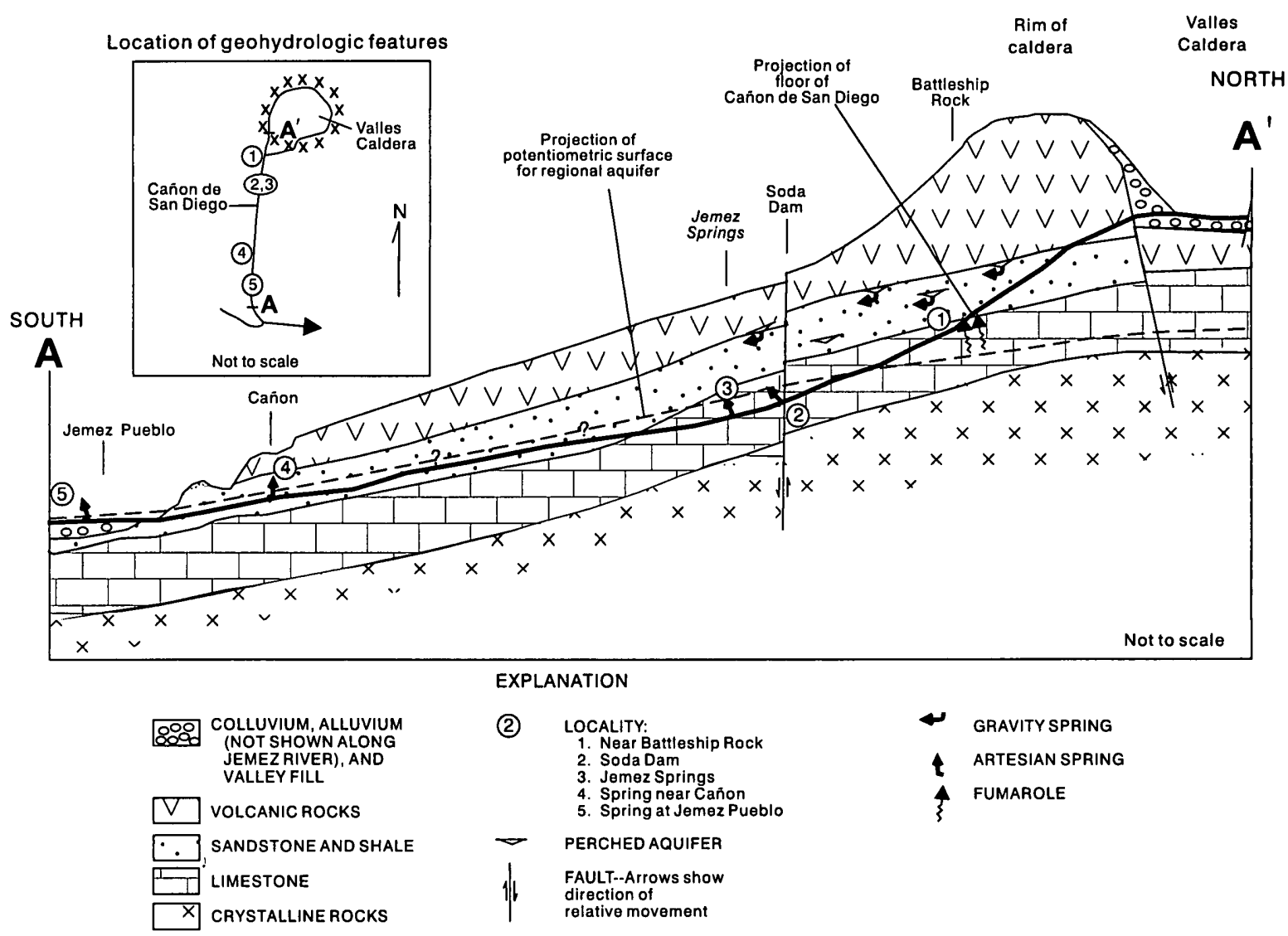

Figure 26.--Diagrammatic section showing generalized geohydrologic setting in Cañon de San Diego. 
From the ring-fracture zone, the canyon floor descends southward through much of the rock section. Limestone is exposed in the canyon floor from Battleship Rock (no. 1, fig. 26) to south of Jemez Springs (no. 3, fig. 26); farther south the canyon floor cuts into the overlying sandstone and shale and cuts into alluvium and valley fill near Jemez Pueblo. Geothermal fluid leaves Valles Caldera by way of cavernous zones in the limestone; minimal evidence suggests that flow in the limestone continues beyond Jemez Springs, possibly as far as Jemez Pueblo. The potentiometric surface is below the canyon floor at Battleship Rock, where a 200-ft test hole penetrated unsaturated rock containing thin zones of perched water. Between this site and Soda Dam, at some place not yet identified, the potentiometric surface rises above the level of the canyon floor; the springs at Soda Dam and Jemez Springs are artesian. So far as is known, the thermal water is confined south of Jemez Springs, where nearly everywhere sandstone and shale overlie the limestone. Evidence of this confinement is available at only a few places near Cañon and Jemez Pueblo, however, and chemical comparisons between the mineral water from Valles Caldera and mineral water at the southern end of the Nacimiento Mountains, near Jemez Pueblo, are not known in detail.

Earlier studies noted remarkable differences in temperature, chemical composition, and constituent concentrations between the mineral water at Soda Dam and at Jemez Springs, indicating flow along different paths. A principal difference is in $\mathrm{SO}_{4}$ content, which is larger at Jemez Springs than in any other spring or well. Smaller but still anomalous $\mathrm{SO}_{4}$ concentrations in ground water occur along much of the length of the canyon; they are thought to reflect the oxidation of $\mathrm{H}_{2} \mathrm{~S}$ that has escaped upward from the thermal-water conduits. This mechanism does not, however, adequately explain the large $\mathrm{SO}_{4}$ content of the water at Jemez Springs.

\section{Area near Rim of Caldera}

The geohydrologic setting in Cañon de San Diego just outside the rim of the caldera is complex. First, this locality is in the principal area of fumaroles outside the caldera (Bailey, 1961), which indicate the presence of boiling fluid at depth. A second notable characteristic is the diverse occurrence of shallow ground water. Three springs (H-31, H-32, H-35) on the hillside drain three different perched water-yielding zones in the limestone, and two test holes (H-29, H-30) penetrate two additional perched zones in limestone. A water-supply well (H-33) taps unconfined water, about
$15 \mathrm{ft}$ beneath river level, thought to represent a groundwater mound beneath the stream. Chemical data (table 8) for water samples from those six sources show the water to be distinctly different from one another. Well $\mathrm{H}-33$ yields native ground water, but the other two wells and three springs yield water that contains components of geothermally derived materials $(\mathrm{Cl}$, trace constituents) and ranges widely in composition and concentration.

Samples from well H-29 and spring H-32 (fig. 27A) indicate most clearly the mixture of geothermal and nongeothermal constituents (see, for comparison, site 5 in fig. 20). The sample from well $\mathrm{H}-30$ is typical of water in limestone, although its position in figure 27A suggests a mixture with a small proportion of geothermal water (hence its appreciable contents of $\mathrm{Li}$ and $B$, table 8) and with water of near-surface volcanicalluvial origin (well $\mathrm{H}-33$ ). Therefore, well $\mathrm{H}-30$ likely intersects the outer edge of the ground-water mound beneath the river, which may extend westward into the limestone.

The sample from spring $\mathrm{H}-31$ is in an anomalous position in the diamond plot in figure $27 \mathrm{~A}$, but its composition can be seen more clearly in the semilogarithmic plot in figure 27B. The sample has small concentrations of $\mathrm{Ca}$ and $\mathrm{Cl}$ and a large concentration of $\mathrm{Na}$. This characteristic is attributed to cation exchange by which the water lost $\mathrm{Ca}$ and gained $\mathrm{Na}$.

Periodic observations revealed two types of water-level fluctuations in this area near the caldera rim. Spring H-32 drains a water-yielding zone in the limestone that is in hydraulic connection with the river at some point upstream, and fluctuations in discharge and chemical composition of the spring water reflect changes in the amount of recharge from the stream. Well H-29 intersects a water-yielding zone in the limestone that seems to be hydraulically isolated from the river; thus, its fluctuations are independent of stream stage.

Spring H-32 was observed periodically for nearly 2 years (fig. 28). Concentrations of the indicator constituents $\mathrm{Cl}$ and $\mathrm{HCO}_{3}$ conversely reflect the fluctuations in stream discharge. Fluctuations were conspicuous in 1973, a year of large spring floods in the river, and inconspicuous during 1974. The plots for $\mathrm{Cl}$ and $\mathrm{HCO}_{3}$ (1973) show that stream water, which began to enter the aquifer during the rising river stage in early March, mixed with the resident ground water proportional to the increase in spring discharge. 
Table 8. Chemical analyses of six ground-water samples, Cañon de San Diego near the rim of Valles Caldera

[Concentrations in milligrams per liter; --, no data; ${ }^{\circ} \mathrm{C}$, degrees Celsius. Locations shown in figure 31. Analyses from Trainer, 1978, table 5, except for well H-33 from Purtymun and others, 1974, table X]

\begin{tabular}{|c|c|c|c|c|c|c|}
\hline $\begin{array}{l}\text { Constituent or } \\
\text { property }\end{array}$ & $\begin{array}{c}\text { Well H-29, } \\
\text { depth } 54 \\
\text { feet }\end{array}$ & $\begin{array}{l}\text { Well H-30, } \\
\text { depth 76-90 } \\
\text { feet }\end{array}$ & Spring H-31 & Spring H-32 & Spring H-35 & $\begin{array}{c}\text { Well H-33, } \\
\text { depth } 50 \\
\text { feet }\end{array}$ \\
\hline Silica $\left(\mathrm{SiO}_{2}\right)$ & 37 & 37 & 24 & 45 & 17 & 34 \\
\hline Calcium (Ca) & 210 & 130 & 19 & 140 & 35 & 22 \\
\hline Magnesium (Mg) & 59 & 25 & 44 & 13 & 46 & 5 \\
\hline Sodium $(\mathrm{Na})$ & 570 & 100 & 720 & 390 & 840 & $1_{9}$ \\
\hline Potassium (K) & 34 & 11 & 66 & 51 & 45 & -- \\
\hline Carbonate $\left(\mathrm{CO}_{3}\right)$ & 0 & 0 & 154 & 0 & 0 & 0 \\
\hline $\begin{array}{c}\text { Bicarbonate } \\
\left(\mathrm{HCO}_{3}\right)\end{array}$ & ${ }^{2} 1,611$ & 660 & 1,550 & 761 & 1,810 & 84 \\
\hline Sulfate $\left(\mathrm{SO}_{4}\right)$ & 290 & 32 & 150 & 32 & 280 & 11 \\
\hline Chloride $(\mathrm{Cl})$ & 300 & 61 & 120 & 470 & 330 & 6 \\
\hline Fluoride $(\mathrm{F})$ & 1.6 & 1.0 & 9.1 & 4.6 & 6.5 & .7 \\
\hline Arsenic (As) & .058 & .005 & .009 & -- & .004 & -- \\
\hline Boron (B) & 2.3 & .510 & 4.3 & .710 & 4.0 & -- \\
\hline Bromide $(\mathrm{Br})$ & 1.1 & .3 & .4 & -- & 1.0 & -- \\
\hline Lithium (Li) & 2.1 & .690 & 2.2 & -- & -- & -- \\
\hline Dissolved solids & 2,260 & 728 & 2,080 & 1,520 & 2,500 & 134 \\
\hline $\begin{array}{l}\text { Specific } \\
\text { conductance } \\
\text { (microsiemens } \\
\text { per centimeter } \\
\text { at } 25^{\circ} \mathrm{C} \text { ) }\end{array}$ & $2_{3,200}$ & ${ }^{2} 1,100$ & ${ }^{2} 2,700$ & ${ }^{2} 2,200$ & 3,660 & 140 \\
\hline Date & $10-24-73$ & $3-21-74$ & $9-24-73$ & $1-17-73$ & $5-25-73$ & $5-08-73$ \\
\hline
\end{tabular}

${ }^{1} \mathrm{Na}+\mathrm{K}$, as $\mathrm{Na}$.

${ }^{2}$ Measured in field. 
(A)

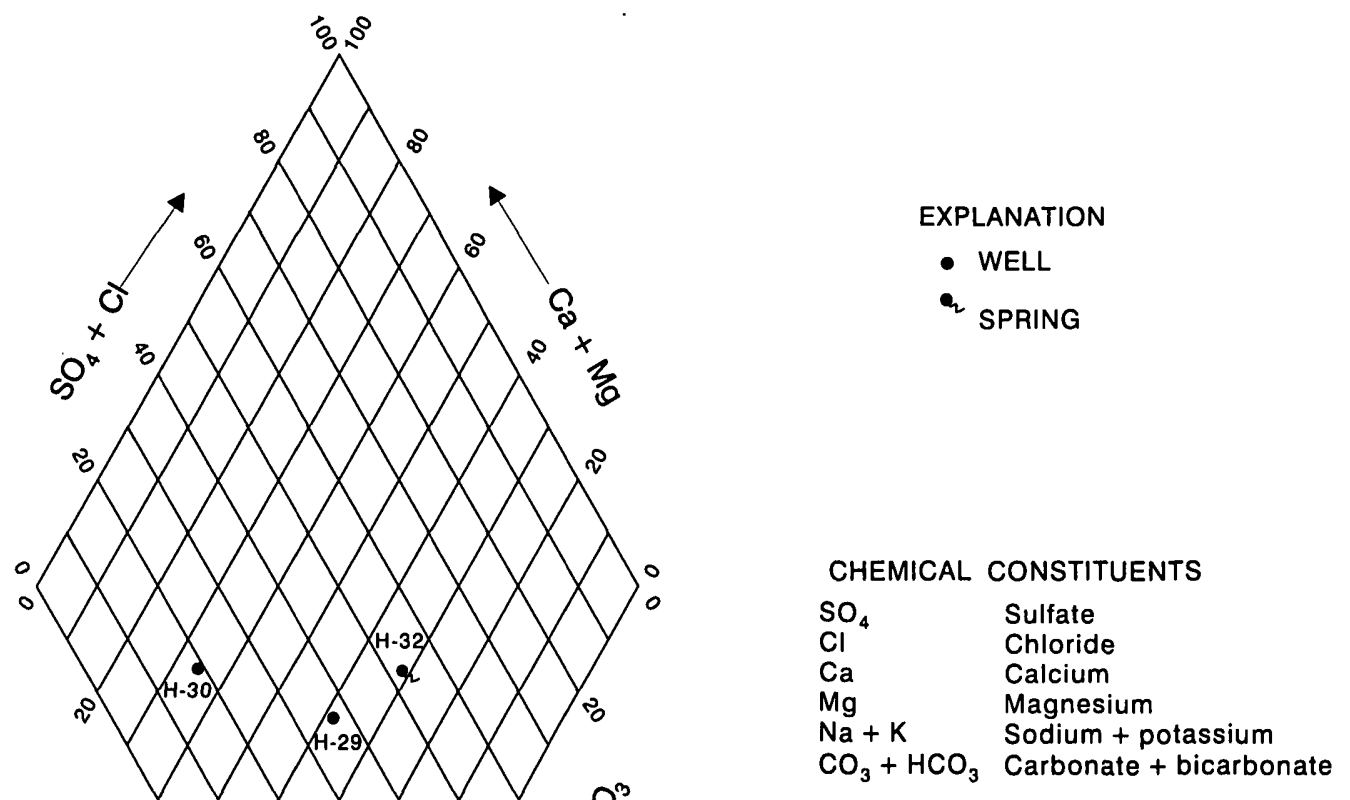

(B)

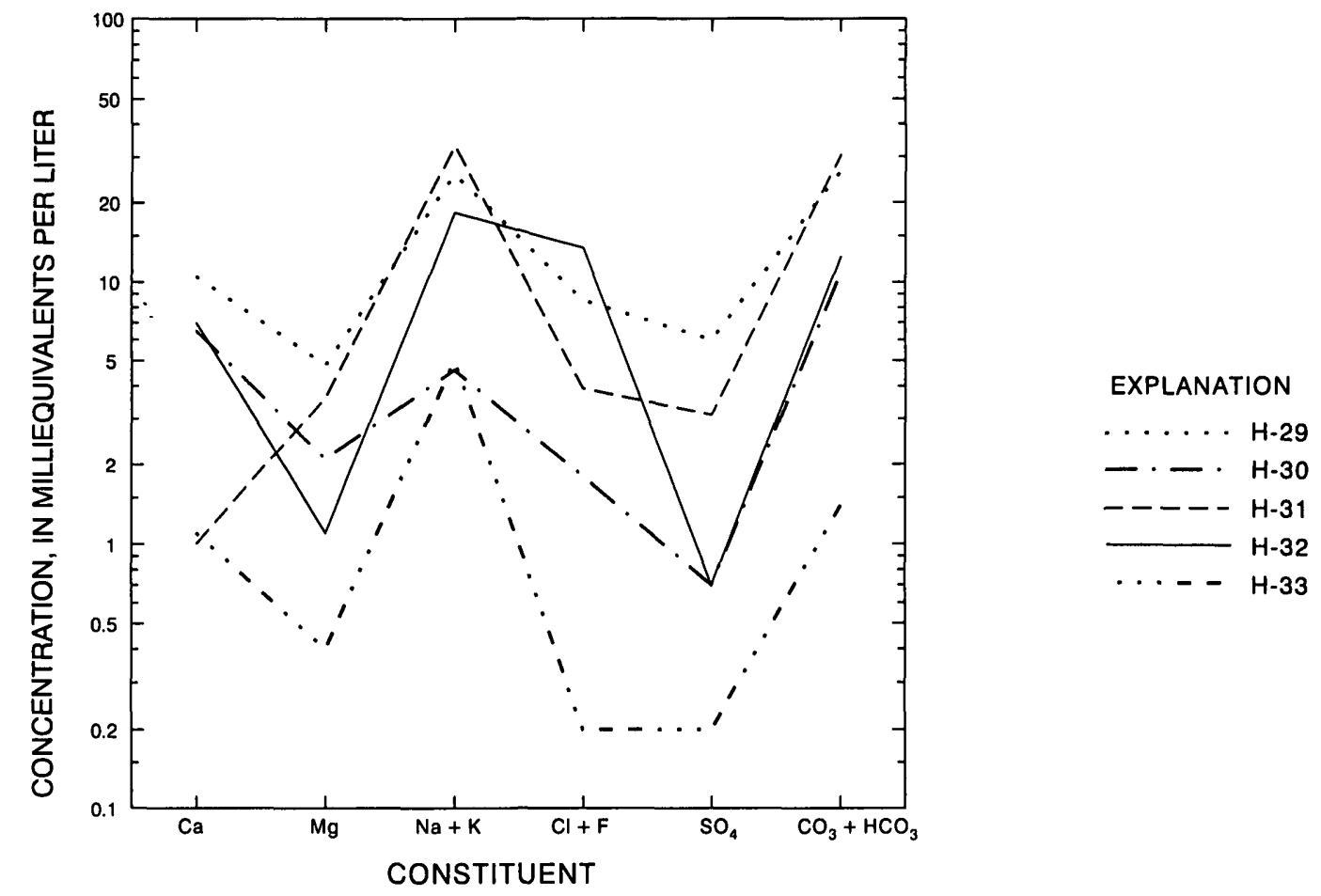

Figure 27.--(A) Major-ion composition and (B) concentrations in five ground-water samples from Cañon de San Diego near the rim of Valles Caldera. 
Stream discharge data (not shown) indicate that the annual flood peaked in the first half of May. The rapid response of the aquifer to changes in river stage indicates effective hydraulic interconnection that must be higher than the altitude of the spring, a short distance upstream. Presumably the entrance to the water-yielding zone in limestone is less than the high stage of a large flood but out of reach of small floods (such as in 1974) and lower river stages. Tritium data (Trainer, 1978, table 8A) help support the

interpretation that stream water enters the bedrock: the concentration of tritium in water from spring H-32 on March 8, 1973, was 18.8 $\pm 2.1 \mathrm{TU}$ and on May 22, 1973 , was $75.0 \pm 4.0 \mathrm{TU}$.

In an earlier study (Trainer, 1984) fluctuations of constituent concentrations in the mineral springs at Soda Dam and Jemez Springs, for which observations are available for random dates over periods of years, were studied by constructing plots of 2-month running median values of selected constituents and discharge. Such plots for spring H-32 and for the Jemez River below East Fork near Jemez Springs (08321500) (fig. 29) generally repeat the pattern seen in figure $28 . \mathrm{Cl}$ and $\mathrm{HCO}_{3}$ concentrations show the same relation shown in figure 28; however, the concentration of $\mathrm{SO}_{4}$, in contrast, is rather stable during much of the fluctuation of the other constituents in the plot but increases conspicuously during recession from the spring-flood peak in the river. This behavior, plus the odor of $\mathrm{H}_{2} \mathrm{~S}$ present most days in this fumarolic area (and present also in water from wells $\mathrm{H}-29$ and $\mathrm{H}-30$ ), suggests that part of the $\mathrm{SO}_{4}$ in ground water has been produced in the aquifer by the oxidation of $\mathrm{H}_{2} \mathrm{~S}$ rising through it:

$$
\mathrm{H}_{2} \mathrm{~S}+4 \mathrm{H}_{2} \mathrm{O}=\mathrm{SO}_{4}^{-2}+10 \mathrm{H}^{+}+8 \mathrm{e}^{-}
$$

(Hem, 1970, p. 161). Two hypotheses are suggested to account for the timing of the surge in $\mathrm{SO}_{4}$ concentrations: (1) the rise of ground-water level during an episode of recharge temporarily reduces the availability of $\mathrm{H}_{2} \mathrm{~S}$ by retarding its upward movement, whereas the recovery of the dissolved-solids concentration during recession from the flood peak is accompanied by renewed oxidation of $\mathrm{H}_{2} \mathrm{~S}$ and production of $\mathrm{SO}_{4}$ and (2) widespread temporary saturation of the soil during melting of snow cover may interrupt the connection between soil and rock pores and the atmosphere, temporarily retarding the ascent of $\mathrm{H}_{2} \mathrm{~S}$ through the unsaturated rock column. The second explanation is thought the more likely because (1) concentrations of $\mathrm{SO}_{4}$ are elevated at other sites downcanyon (discussed in a subsequent paragraph), (2) ground water at those other sites is not diluted by surface water, and (3) there is little if any recharge from land surface to cause dilution.

Test holes $\mathrm{H}-29$ and $\mathrm{H}-30$ were drilled into limestone at sites a few feet apart. H-29, $54 \mathrm{ft}$ deep, penetrates a water-yielding zone at $50 \mathrm{ft}$. Hole $\mathrm{H}-30$ was finished with two pipes. One is open, from 76 to 90 $\mathrm{ft}$, to a water-yielding zone first penetrated at $85 \mathrm{ft}$. The other pipe extends to $200 \mathrm{ft}$, is capped at the bottom, and contains water from 118 to $200 \mathrm{ft}$. Water was placed in this second pipe to provide a medium in which to measure the temperature profile, but the water level in the pipe dropped to $118 \mathrm{ft}$, evidently because of a leak at that level. After this pipe was installed a concrete plug was set around it at 90 to $100 \mathrm{ft}$; the hole and wallrock are unsaturated from 100 to $200 \mathrm{ft}$. The thermal profile was measured in the 118 - to $200-\mathrm{ft}$ segment of water-filled pipe after the temperature around the hole stabilized.

The observed thermal gradient of $4{ }^{\circ} \mathrm{C}$ over a 66$\mathrm{ft}$ range in depth in $\mathrm{H}-30$ is equivalent to $6.1^{\circ} \mathrm{C}$ per 100 $\mathrm{ft}$, a high near-surface gradient even in a geothermal region. If the thermal conductivity of the limestone is assumed to be $6 \times 10^{-3} \mathrm{cal} / \mathrm{cm} \mathrm{sec}^{\circ} \mathrm{C}$ (Clark, 1966, p. 462), the heat flow implied by the observed gradient is about 12 HFU. If the thermal profile continued downward at the observed gradient, the boiling point (about $93^{\circ} \mathrm{C}$ at 6,000 - $\mathrm{ft}$ altitude) would be reached at a depth of about $1,080 \mathrm{ft}$. The top of the limestone is about $250 \mathrm{ft}$ above land surface near $\mathrm{H}-30$. If the total thickness of limestone were about $1,200 \mathrm{ft}$, as in wells GT-2, PC-1, and VC-1, the base of the formation would be about $900 \mathrm{ft}$ below land surface at the well site. These figures suggest that the deep conduit is in the basal limestone, in the upper part of the crystalline rock, or both. Perched ground water in each wateryielding zone above the geothermal conduit(s) sweeps away part of the heat carried upward by conduction through unsaturated rock and by convection (in vapor) through fractures. Any additional perched water in the section beneath test hole $\mathrm{H}-30$ would add to the uncertainty. The cumulative effect of all such wateryielding zones on heat flow to the surface cannot be estimated from the data available. 


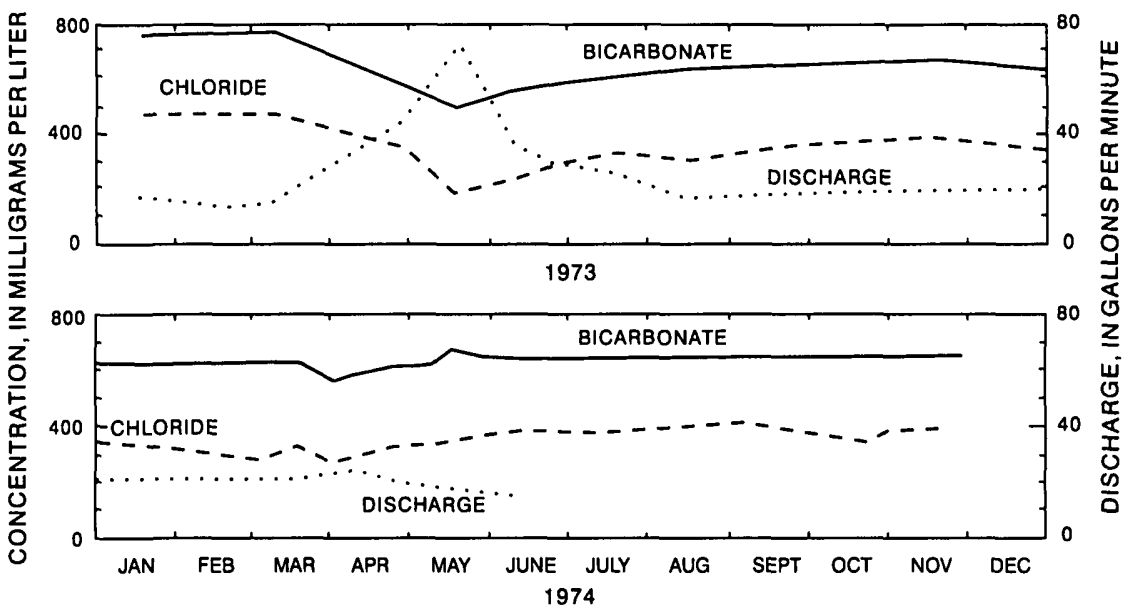

Figure 28.--Fluctuations in bicarbonate and chloride concentrations and discharge of spring $\mathrm{H}-32$ located near the rim of Valles Caldera, 1973-74.
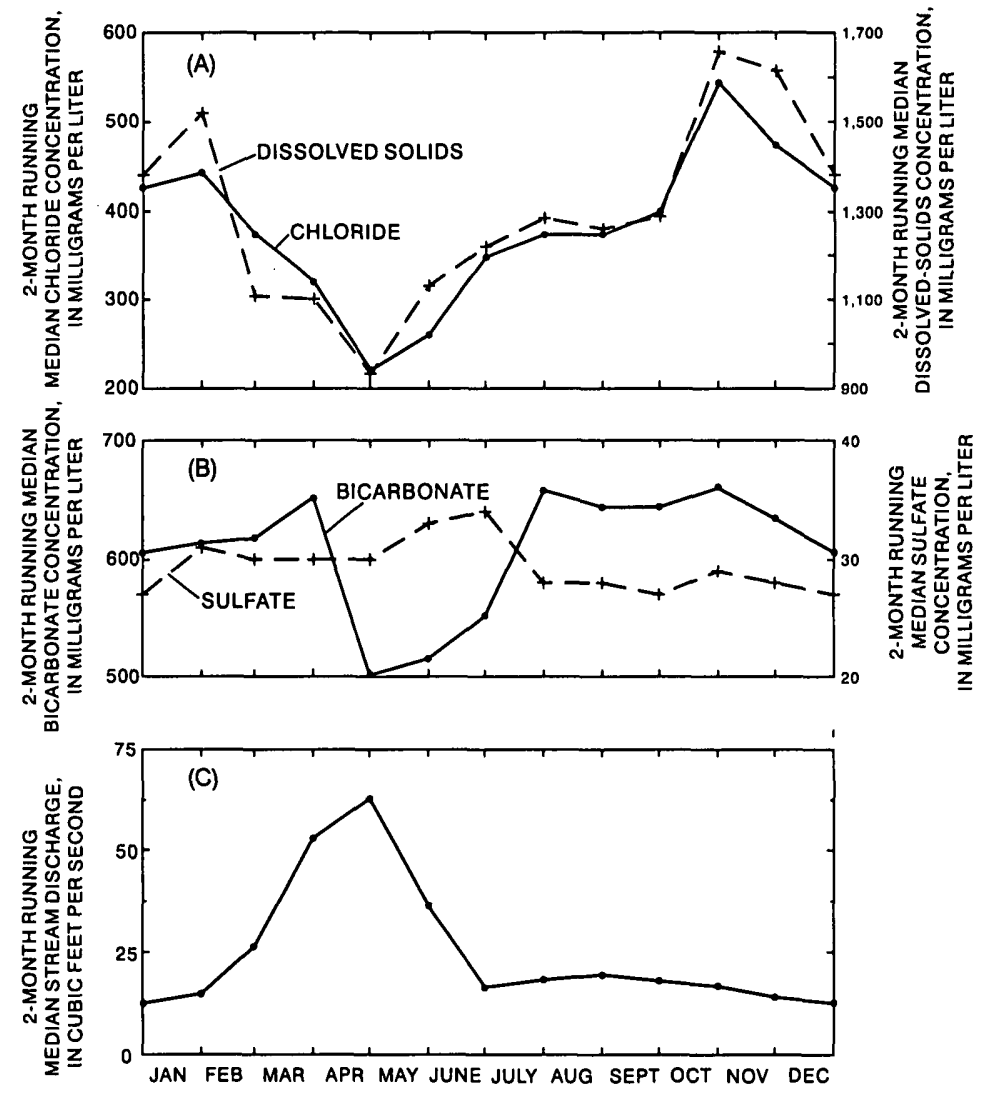

Figure 29.--(A,B) Fluctuations in concentrations of selected ions in spring $\mathrm{H}-32$ and (C) streamflow discharge at Jemez River below East Fork, near Jemez Springs (08321500). Point plotted January 31 is median for all samples collected in January or February; point plotted February 28 is median for February and March samples; and so on. 
Selected variables also were measured periodically in wells $\mathrm{H}-29$ and $\mathrm{H}-30$, although the test drilling was not completed until late 1973. The record available (fig. 30) is similar to the 1974 record for spring H-32 (fig. 28); the principal exception is timing of the maximums/minimums in variables during the spring flood. During 1974 the spring flood at Jemez River below East Fork, near Jemez Springs peaked in late March. As discussed earlier, well H-30, and possibly well H-29, may tap the outer edge of the ground-water mound beneath the Jemez River. Differences in potentiometric levels and water chemistry indicate that the water-yielding zones tapped by wells $\mathrm{H}-29$ and $\mathrm{H}-30$ are hydraulically separated, but this is unlikely if both water-yielding zones are in contact with the recharge mound beneath the river. The content of geothermal indicator ions in both well waters indicates that both water-yielding zones receive inflow and dissolved loads from a source of mixed water. The most plausible explanation for the data in figure 30 is that each well taps a zone containing mixed water and that, at least during the spring flood, each zone is open to the river upstream through channels in the limestone sufficiently near the well site to explain the rapid response shown in the hydrographs. The setting probably is similar to that for spring H-32 (fig. 28) but with less effective connection to the stream. The water-yielding zones in all limestone springs and wells described in the foregoing paragraphs are thought to consist chiefly of interconnected bedding-plane openings.

The coincidence of fumarolic $\mathrm{H}_{2} \mathrm{~S}$ and high concentrations of $\mathrm{SO}_{4}$ in well and spring water in the canyon near the caldera rim suggests the hypothesis that part of the $\mathrm{SO}_{4}$ in ground water is produced locally. Data to support this hypothesis are summarized in figure 31 . The trend line in figure $31 \mathrm{~A}$ was drawn using the data for caldera wells, well VC-1, and springs H-6 (Soda Dam) and H-14 (Jemez Springs), all of which represent either geothermal reservoir or derivative water. As extended toward the lower left this line fits fairly well the upper part of the distribution field for all other wells and springs, most of which are situated in or near Cañon de San Diego. Some samples are believed to contain a geothermal component (D-6, H29, $\mathrm{H}-30, \mathrm{H}-31, \mathrm{H}-32$, and $\mathrm{H}-35$ and perhaps $\mathrm{E}-7$ and $\mathrm{H}-21)$; other samples do not (H-39, H-42, and P-12). Other samples may contain a geothermal component, but the data are not fully convincing. However, figure $31 \mathrm{~B}$ shows that many of the samples in the canyon proportionately contain more $\mathrm{SO}_{4}$ than the caldera well samples. By taking dilution into account, several waters (VC-1, H-6, H-14, H-29, H-31, H-32, H-35) contain larger concentrations of $\mathrm{SO}_{4}$ than most or all of the caldera well samples.

High concentrations of $\mathrm{SO}_{4}$ in ground water have rarely been detected in the southwestern Jemez Mountains outside Cañon de San Diego. Data for five springs were summarized for comparison with the data shown in figure 31B. Purtymun and others $(1975,1976$, 1978) monitored a native-water spring that drains volcanic rocks in Lake Fork Canyon (fig. $31 \mathrm{C}$ ); the median of $26 \mathrm{Cl}$ analyses is $4 \mathrm{mg} / \mathrm{L}$, and the median of $25 \mathrm{SO}_{4}$ analyses is $4 \mathrm{mg} / \mathrm{L}$. Two springs in Church Canyon, a few hundred yards east of Jemez Springs, issue from volcanic rocks at their contact with Abo Formation sandstone. Median values for 27 composite samples from these springs (Purtymun and others, $1975,1976,1978)$ are $6 \mathrm{mg} / \mathrm{L}$ for $\mathrm{Cl}$ and $8 \mathrm{mg} / \mathrm{L}$ for $\mathrm{SO}_{4}$. Twenty-seven samples from Sino and Agua Durme Springs (Purtymun and others, 1975, 1976, 1978; Shevenell and others, 1987) near VA-136 (fig. $31 \mathrm{C}$ ) have median values of $4 \mathrm{mg} / \mathrm{L}$ for $\mathrm{Cl}$ and $3 \mathrm{mg} / \mathrm{L}$ for $\mathrm{SO}_{4}$.

These springs are unlikely to yield water containing high $\mathrm{SO}_{4}$ concentrations because they are isolated from the Cañon de San Diego ground-water system either by distance (Lake Fork Canyon) or by geohydrologic setting (Church Canyon; Sino and Agua Durme Springs). No data are available in the study area to demonstrate $\mathrm{SO}_{4}$ concentration in local limestone outside the Cañon de San Diego flow system. Thus, the tentative conclusion that high $\mathrm{SO}_{4}$ concentrations (fig. 31B) reflect local oxidation of fumarolic $\mathrm{H}_{2} \mathrm{~S}$ cannot be fully tested. This topic is considered further in the following discussion of the mineral springs at Jemez Springs and Soda Dam.

\section{Jemez Springs and Soda Dam}

The springs at Jemez Springs issue from alluvium beside the Jemez River, but the water comes from underlying bedrock. The areal distribution of some of the springs suggests that their source is fractures within the underlying bedrock. Several of the springs, which maintain their positions even after submergence by flooding, are probably the outlets of travertine-lined tubes in the alluvium. Others are constructed; one appears to be a dug well lined with stones and another the outlet of a tile drain. 

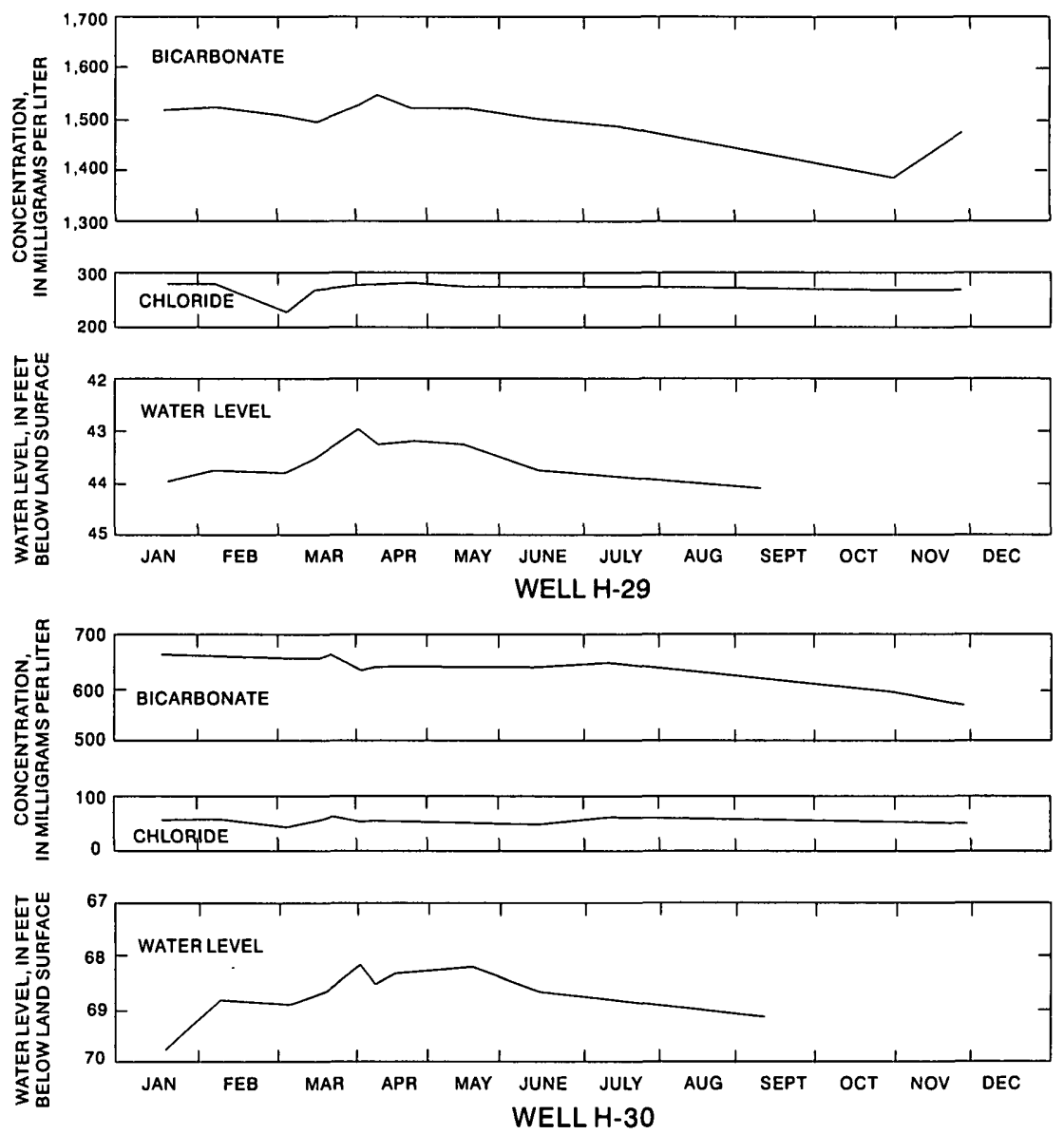

Figure 30.---lon-concentration and water-level fluctuations in wells $\mathrm{H}-29$ and $\mathrm{H}-30,1974$.

At Soda Dam, spring flow issues from fractured limestone and gneiss in the floor of Cañon de San Diego at a point where one section of the Jemez Fault separates (fig. 5) and bounds a horst, forming a hill above the canyon floor. That section of fault continues through the mesa west of Jemez Springs. Another seemingly separate section of fault extends southwestward beneath the village but is concealed farther south beneath canyon-floor deposits.

A test well at Jemez Springs was drilled to a depth of about $800 \mathrm{ft}$. Goff and Kron (1980) presented a lithologic log of the well, and Goff and others (1981) provided additional geologic information about the log and chemical and isotopic analyses of water samples. The well penetrated, in descending order, about $70 \mathrm{ft}$ of gravel, $700 \mathrm{ft}$ of limestone and sandstone, and $60 \mathrm{ft}$ of gneiss. Water was noted at several levels within the gravel. Confined thermal water was found at the alluvium-limestone contact and at about $500 \mathrm{ft}$ in fractured shale within the Madera Limestone. No water was present at the top of or within the gneiss.

Numerous measurements of discharge of single springs at Jemez Springs and Soda Dam ranged from less than 1 to $72 \mathrm{gal} / \mathrm{min}$. Measurements of individual springs are not representative of an entire group of springs, however, because many springs are located within the streambed. Summers (1976, p. 36-37) concluded that total spring flow at Soda Dam, as indicated by increased streamflow, was $0.6 \mathrm{ft}^{3} / \mathrm{s}$ (about $268 \mathrm{gal} / \mathrm{min}$ ) on August 2, 1949. 

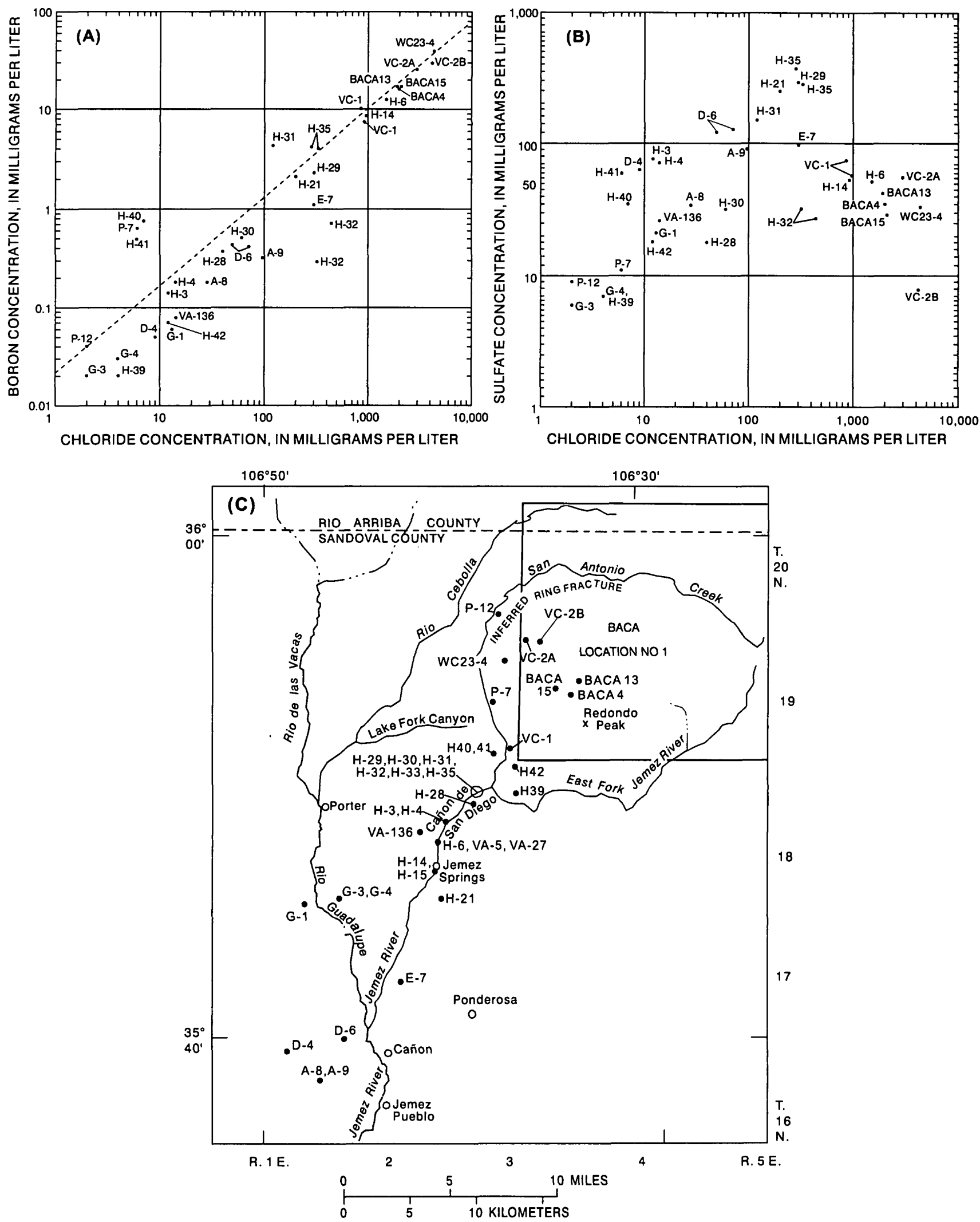

Figure 31.--(A) Chloride and boron and (B) chloride and sulfate in water from wells and springs in the Valles Caldera and Cañon de San Diego area and (C) map showing location of wells and springs (data from Purtymun and others, 1975, table II; Trainer, 1978, table 5; White, 1986, table 1; Shevenell and others, 1987, table B-II; and Goff and others, 1988 , table 2 , and 1992). 
In five of six measurements made in 1973 (table 9), a net loss in stream discharge occurred in the reach passing Soda Dam. Because the downstream set of measurements was made about $1,000 \mathrm{ft}$ below the dam, the decrease in discharge may be due to infiltration into the streambed beginning just downstream from the sill formed by the dam. Similar measurements upstream and downstream from the group of visible springs at Jemez Springs were inconclusive.

Another method used to estimate total spring flow requires only two streamflow measurements and determinations of $\mathrm{Cl}$ concentration for the two groups of springs: one set of measurements downstream from each group of springs. (This is possible because chloride concentration in the river upstream from Soda Dam is so small as to be negligible.) Total spring discharge at Soda Dam is proportional to chloride load in the stream downstream from the dam. At Jemez Springs, total spring discharge is proportional to the difference in chloride loads downstream from the two groups of springs. Measurements during January 1973September 1974 showed the minimum discharge of the Soda Dam Springs (not including loss to infiltration) to range from 111 to $1,046 \mathrm{gal} / \mathrm{min}$; the median of 46 measurements was $365 \mathrm{gal} / \mathrm{min}$. Corresponding values at Jemez Springs ranged from 48 to $1,538 \mathrm{gal} / \mathrm{min}$; the median of 43 values was $333 \mathrm{gal} / \mathrm{min}$. The largest values are thought to be in error beyond those due to infiltration because wading measurements could not be made at high river stages, and therefore discharge values for the Jemez River below East Fork Jemez River (08321500, fig. 6) had to be used as estimates. The conclusions from the limited data are that discharge from each group of springs is several hundred gallons per minute most of the time and that spring flow widely fluctuates with time.

Representative chemical data for Jemez Springs and Soda Dam are listed in table 10. Water at both locations has a $\mathrm{Na} \mathrm{Cl}$ composition and large concentrations of $\mathrm{Ca}$ and $\mathrm{HCO}_{3}$. The ratios $\mathrm{Li} / \mathrm{Na}$, $\mathrm{Li} / \mathrm{Cl}$, and $\mathrm{B} / \mathrm{Cl}$ are in the ranges found by White (1957) to be typical of volcanic waters. The water at Soda Dam is nearly twice as mineralized as that at Jemez Springs. Conversely the Jemez Springs water is hotter-about $75^{\circ} \mathrm{C}$ compared with about $45^{\circ} \mathrm{C}$ at Soda Dam. Both groups of springs emit $\mathrm{H}_{2} \mathrm{~S}$ and exhibit temporal fluctuations in dissolved solids. Both groups have individual springs that appear to be affected by dilution with native ground water.

Plots of typical analyses of mineral water from Jemez Springs and Soda Dam are shown in figure 32. Also in this figure are reconstructed analyses that assume simple dilution of parent reservoir fluid(s) without dissolution of wall rock in flow conduits or other additions of dissolved ions. The large increases in

Table 9. Discharge of the Jemez River upstream and downstream from Soda Dam

[Location of Soda Dam shown in figure 6]

\begin{tabular}{|c|c|c|c|}
\hline \multirow[b]{2}{*}{ Date } & \multicolumn{3}{|c|}{ Discharge, in cubic feet per second } \\
\hline & $\begin{array}{l}\text { Upstream from } \\
\text { Soda Dam }\end{array}$ & $\begin{array}{l}1,000 \mathrm{ft} \\
\text { downstream from } \\
\text { Soda Dam }\end{array}$ & Difference \\
\hline $2-23-73$ & 14.1 & 9.47 & -4.6 \\
\hline $3-20-73$ & 22.8 & 22.7 & -0.1 \\
\hline $3-28-73$ & 33.0 & 29.5 & -3.5 \\
\hline $4-06-73$ & 18.8 & 21.0 & +2.2 \\
\hline $7-02-73$ & 16.4 & 15.6 & -0.8 \\
\hline $7-13-73$ & 24.9 & 23.2 & -1.7 \\
\hline
\end{tabular}




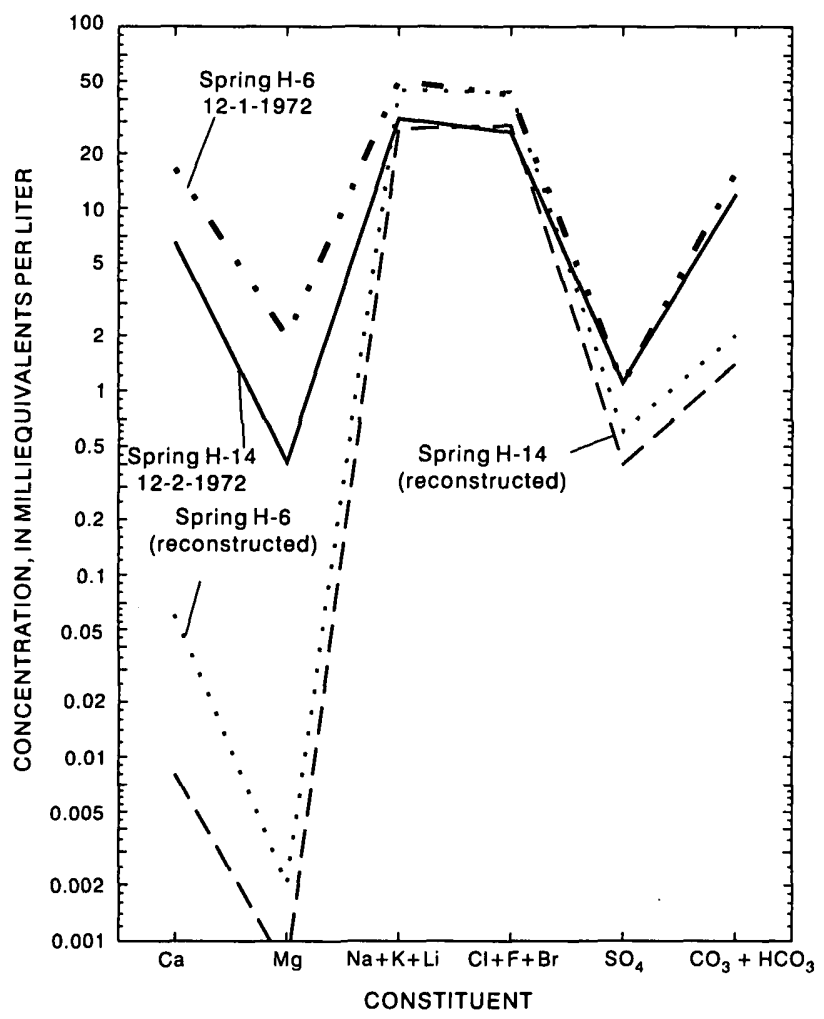

Figure 32.--Actual and reconstructed concentrations of major ions in water from spring $\mathrm{H}-6$ at Soda Dam and spring H-14 at Jemez Springs, 1972. Reconstructed concentrations are based on the assumption of simple dilution of reservoir fluid. Spring locations shown in figure $31 \mathrm{C}$.

concentrations of $\mathrm{Ca}, \mathrm{Mg}$, and $\mathrm{HCO}_{3}$ in each pair of graphs represent dissolution of limestone by flowing thermal water. There seems to be no readily soluble source of $\mathrm{Na}, \mathrm{K}$, and $\mathrm{Cl}$ along flow paths outside the caldera, and these constituents in addition to $\mathrm{Li}, \mathrm{F}$, and $\mathrm{Br}$ act conservatively. An unexplained aspect of each pair of plots is the difference in $\mathrm{SO}_{4}$ content, noted earlier and considered further in a later discussion.

The samples represented in table 10 were selected in part to illustrate the considerable range in concentrations typical of mineral water at Jemez Springs and Soda Dam. The degree of dilution during mixing of the fluids can be estimated with the massbalance equation used in earlier sections of this report. For example, using the more concentrated sample from spring $\mathrm{H}-14$ in table 10 and assuming ground water from Baca $4(1,991 \mathrm{mg} / \mathrm{L} \mathrm{Cl})$ and VC-2A $(2,943 \mathrm{mg} / \mathrm{L}$ $\mathrm{Cl})$ as parent reservoir fluids indicate dilute-water to thermal-water volume ratios of 1.2:1 for Baca 4 reservoir fluid and 2.2:1 for $\mathrm{VC}-2 \mathrm{~A}$ reservoir fluid (table 11). Because of uncertainty over the identity of geothermal and dilute parent water, these calculated mixing proportions need to be considered estimates.

\section{Fluctuations in Constituent Concentrations}

Review of the series of analyses of mineral water from Jemez Springs and Soda Dam shows that the water has maintained its typical chemical character over the period represented by "modern" analyses-at least since the study by Kelly and Anspach (1913). Concentrations of constituents have shown substantial fluctuation, however.

An approach to analyzing fluctuations in concentration, used in an earlier study (Trainer, 1984) and in the previous discussion of spring H-32 (fig. 29), consists of summarizing analytical data by month of sampling. Even with the large data set now available, however, some monthly subsets contain only a few samples and hence may be less representative than other subsets. This problem was addressed by summing the data in 2-month subsets to increase sample size and plotting 2-month running median values monthly (for example, January-February median plotted on February 1, February-March median plotted on March 1, and so on). The resulting runningmedian curves are shown in figure 33. For streamflow, mean monthly values were used instead of medians because of easier computation and the large amount of available data. 


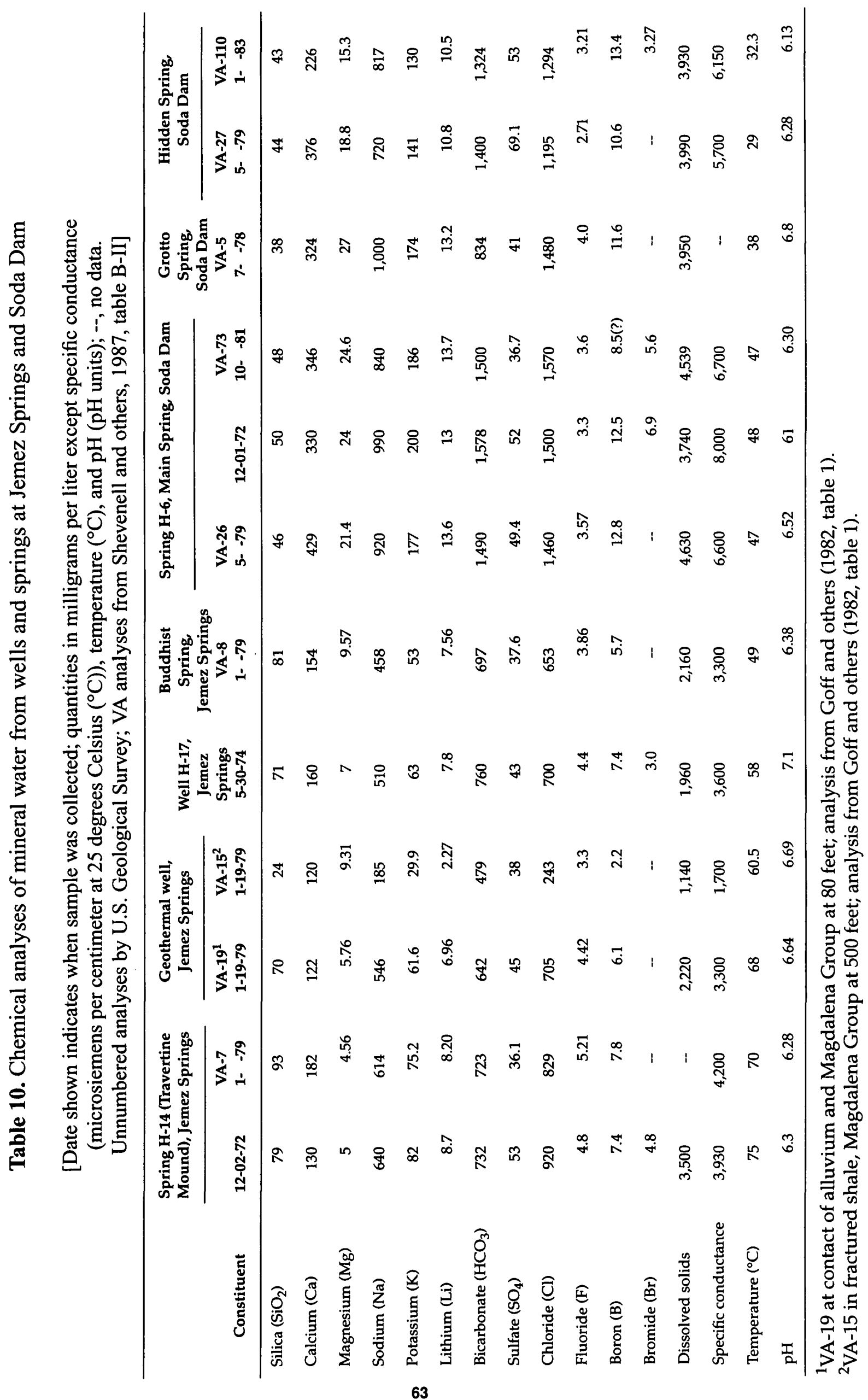


(A)
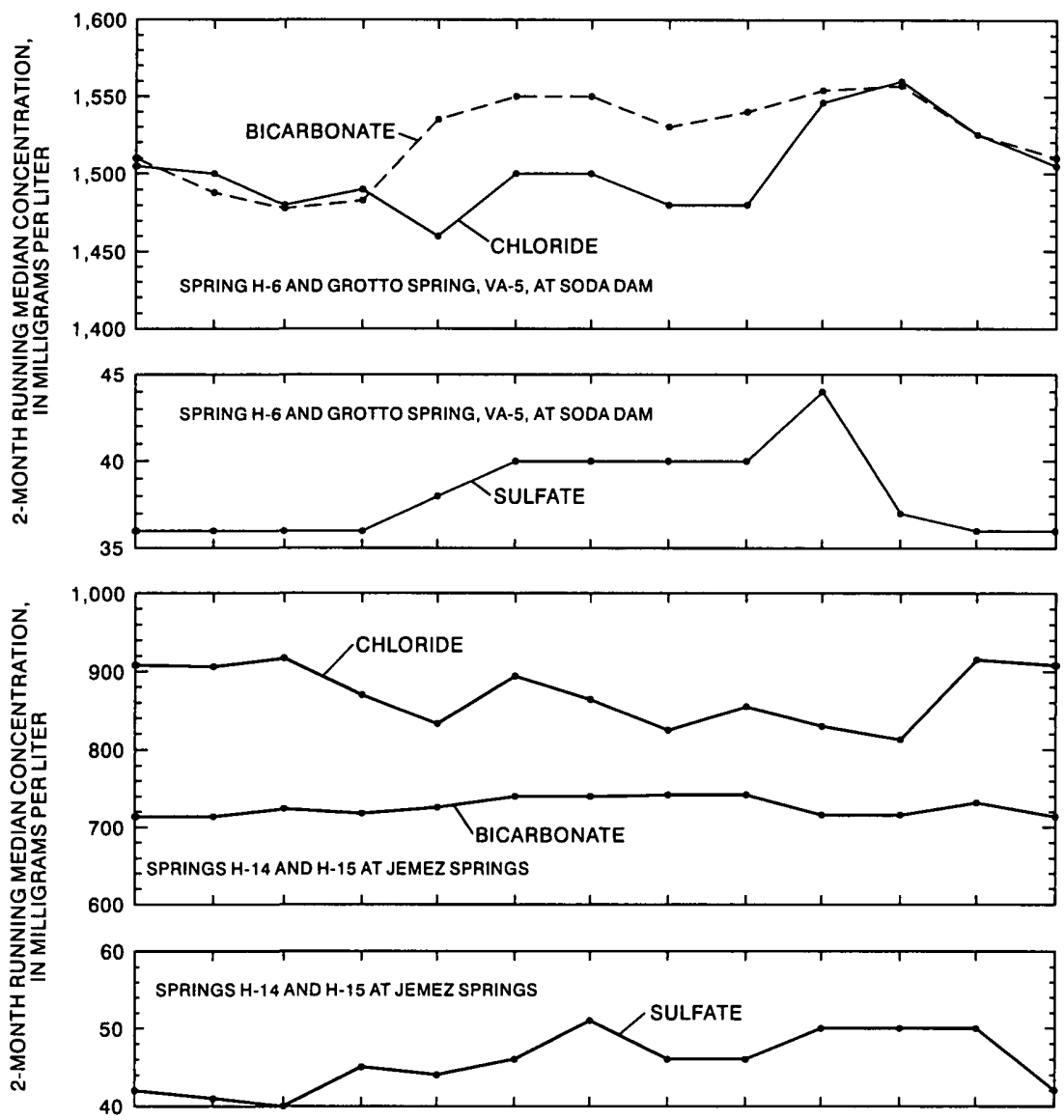

zo

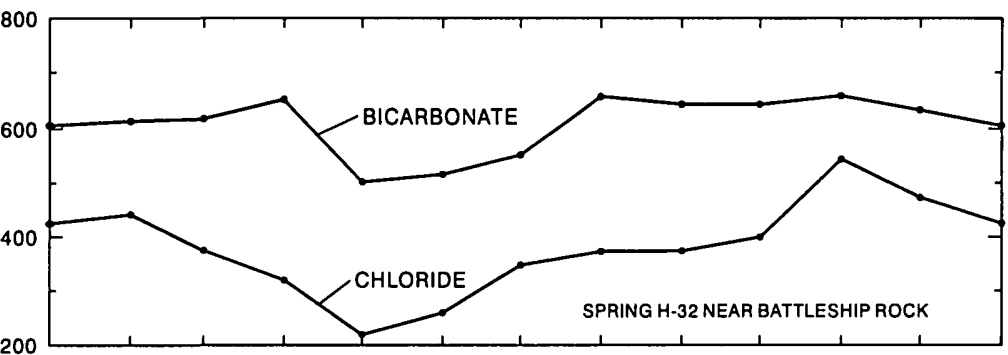

(B)
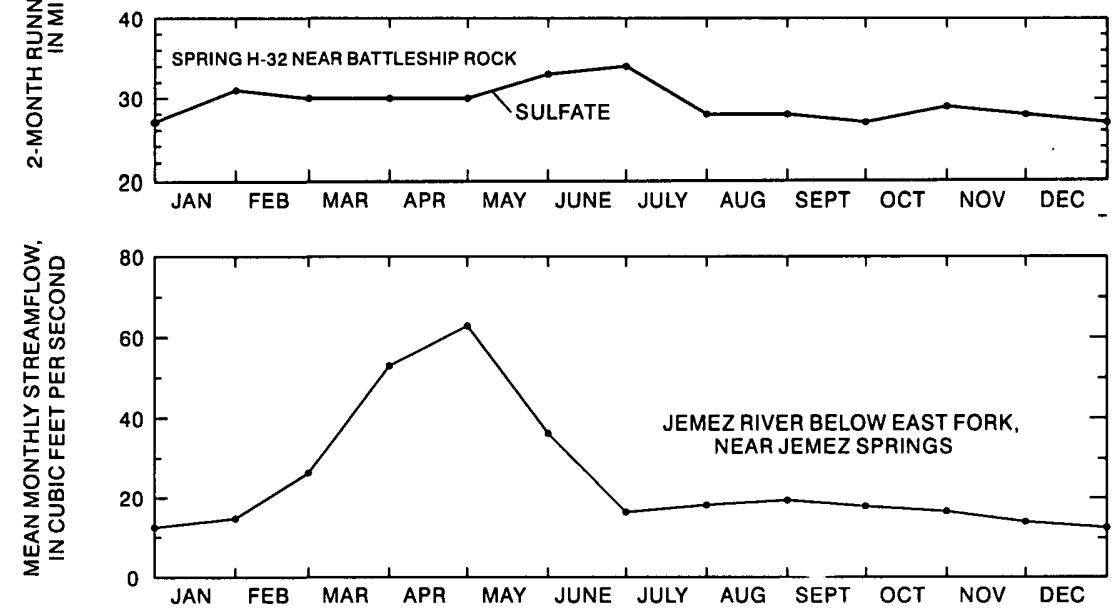

Figure 33.--Fluctuations in (A) 2-month running median concentrations of selected ions in springs, 1973-86 and (B) mean monthly streamflow in the Jemez River below East Fork, near Jemez Springs (08321500), 1963-76. 
Table 11. Example of degree of dilution calculated for typical mineral-water samples from Jemez Springs and Soda Dam using two assumed parent reservoir fluids

[Locations shown in figure 31C. Data from Trainer (1978, table 5), White (1986, table 1), Shevenell and others (1987, table B-II), and Goff and others (1988, table 2). Dilution is characterized as the volume of dilute water that, when mixed with one volume of reservoir fluid, would produce a mixture like the measured mineral water. $\mathrm{mg} / \mathrm{L}$, milligrams per liter]

\begin{tabular}{|c|c|c|c|c|}
\hline \multirow{3}{*}{$\begin{array}{c}\text { Parent } \\
\text { reservoir } \\
\text { fluid, sample } \\
\text { date, and } \\
\text { chloride } \\
\text { concentration }\end{array}$} & \multicolumn{4}{|c|}{ Mixed water } \\
\hline & \multicolumn{2}{|c|}{ Spring H-14, Jemez Springs } & \multicolumn{2}{|c|}{$\begin{array}{l}\text { Spring H-6, Main Spring, } \\
\text { Soda Dam }\end{array}$} \\
\hline & $\begin{array}{c}\text { 12-02-72, } \\
\mathrm{Cl}, 920 \mathrm{mg} / \mathrm{L}\end{array}$ & $\begin{array}{c}\text { 1-79, } \\
\mathrm{Cl}, 829 \mathrm{mg} / \mathrm{L}\end{array}$ & $\begin{array}{c}10-81 \\
\mathrm{Cl}, 1,570 \mathrm{mg} / \mathrm{L}\end{array}$ & $\begin{array}{c}5-79, \\
\mathrm{Cl}, 1,460 \mathrm{mg} / \mathrm{L}\end{array}$ \\
\hline $\begin{array}{l}\text { Baca 4, } \\
\quad 6-11-82 ; \\
\text { Cl, 1,991 mg/L }\end{array}$ & 1.2 volumes & 1.4 volumes & 0.3 volume & 0.4 volume \\
\hline $\begin{array}{l}\text { VC-2A } \\
\text { 8-27-87; } \\
\text { Cl, 2,943 mg/L }\end{array}$ & 2.2 volumes & 2.6 volumes & .9 volume & 1.0 volume \\
\hline
\end{tabular}

The water-chemistry plots in figure 33 illustrate two different settings. Spring H-32 responds rather promptly to periodic dilution by stream water. The plots for Soda Dam and Jemez Springs also are best explained by periodic dilution but at a greater distance from the source, so the effect takes longer to be seen at the springs.

The $\mathrm{Cl}$ plot for spring $\mathrm{H}-32$ shows a major decline in concentration because of dilution by river water during the snowmelt flood, a long period of recovery while the river water drains from local ground-water conduits in the limestone, and a period during which the native ground-water regime is dominant. The reason for the peak concentration in October-November is unknown. The $\mathrm{HCO}_{3}$ plot, generally similar to the $\mathrm{Cl}$ curve, shows the same pattern of dilution and recovery; its consistent slope in late autumn suggests that the sharp peak in $\mathrm{Cl}$ is anomalous. The $\mathrm{SO}_{4}$ plot is basically featureless except for a slight decline during the snowmelt flood and an increase after it. This pattern and the concentrations involved were attributed to production of $\mathrm{SO}_{4}$ in the aquifer from $\mathrm{H}_{2} \mathrm{~S}$ ascending from below and temporary suppression of the process during the flood and recovery afterward. Analyses for water from Baca wells indicate $\mathrm{Cl}$ concentrations of about 1,900 to $2,500 \mathrm{mg} / \mathrm{L}$ and $\mathrm{SO}_{4}$ concentrations of 35 to $42 \mathrm{mg} / \mathrm{L}$ (see table 6). For spring $\mathrm{H}-32$ the corresponding values are about $400 \mathrm{mg} / \mathrm{L} \mathrm{Cl}$ and about $30 \mathrm{mg} / \mathrm{L} \mathrm{SO}$. As noted earlier, flood water is believed to move into the aquifer locally, and the influence of the flood-produced recharge is the dominant control reflected on the chemical hydrographs.

The annual fluctuations in $\mathrm{Cl}$ and $\mathrm{HCO}_{3}$ at Soda Dam are quite different. Conservative $\mathrm{Cl}$ concentrations decline in April-May and in AugustSeptember, whereas nonconservative $\mathrm{HCO}_{3}$ concentrations increase during these two periods, 
perhaps because of enhanced dissolution of rock in conduit walls by the more dilute (undersaturated) water. The annual pattern for $\mathrm{SO}_{4}$ is generally featureless except for a peak after a major episode of dilution. The two annual minimums for $\mathrm{Cl}$ were found in an earlier study (Trainer, 1984, fig. 5) and explained as effects of dilution with a lag time that is dependent on the time required for flow from the site of dilution. In that study the $\mathrm{Cl}$ minimums were correlated with two regional events, the snowmelt flood in spring and a much lower streamflow peak that occurs in many years during September-November. Review of streamflow data shows the autumn peak to be smaller and less frequent than was earlier thought, and in light of the additional data presented here an alternate explanation is thought more likely. Both $\mathrm{Cl}$ minimums at Soda Dam reflect the snowmelt flood. The August-September $\mathrm{Cl}$ low, with its associated $\mathrm{SO}_{4}$ peak (by analogy with spring $\mathrm{H}-32$ ) followed by the maximum mean $\mathrm{Cl}$ concentration, represents dilution at a site that requires at least 4 months travel time to Soda Dam. The AprilMay $\mathrm{Cl}$ low and its associated $\mathrm{HCO}_{3}$ peak represent dilution at a site within a few weeks' travel time of Soda Dam and in a reach of the canyon floor/fault system where relatively little $\mathrm{SO}_{4}$ is locally produced. Because the cavernous nature of conduits in the limestone facilitates relatively rapid flow, the AugustSeptember dilution can be most likely correlated with the snowmelt flood of the same year (a 4-month lag) rather than with a flood of an earlier year (lag time 16 months, or 28 months, and so on). Specific dilution sites cannot be identified, although a distant site in the region from the ring fracture to the area of fumaroles near Battleship Rock and a proximal site nearer Soda Dam seem to be consistent with available data.

The running-median $\mathrm{Cl}$ plot for Jemez Springs (fig. 33A) shows decreases in April-May, July-August, and October-November. Thus, the water at Jemez Springs appears to have had a more complex dilution history than that at Soda Dam-a conclusion that is not surprising because of the greater degree of dilution of the Jemez Springs water (table 11).

Covariation of $\mathrm{SO}_{4}$ and $\mathrm{Cl}$ (fig. 34) provides another means of studying the mineral water. Chemical and isotopic data for individual wells in the Redondo Creek reservoir (Truesdell and Janik, 1986, tables 1, 3; White, 1986, tables 1, 3) show considerable variation, which White (1986, p. 1855) suggested may be due to production testing.
Plots B, C, and D (fig. 34) also exhibit linear distributions of data. Many of the data points are spaced sufficiently close in time to show the sequential change in the relation of $\mathrm{SO}_{4}$ to $\mathrm{Cl}$ (plots $\mathrm{B} 1, \mathrm{Cl}$, and D1) over short periods; the patterns of these changes support the general trends of the lines in corresponding plots $B$ and $D$. These three diagrams represent three different variants of the pattern for the geothermal reservoir(s) (plot A).

The chief factors controlling plots $\mathrm{B}, \mathrm{C}$, and D are believed to be the rate of production of $\mathrm{SO}_{4}$ and the dilution of fluid by mixing. Goff and others (1981, p. 239) identified three sources of $\mathrm{SO}_{4}$ in this region: oxidation of $\mathrm{H}_{2} \mathrm{~S}$ rising from the heat source in the caldera, oxidation of pyrite $\left(\mathrm{FeS}_{2}\right)$ present in crystalline and sedimentary rocks, and reaction of thermal water with organic sulfur in carbonate rocks and shale. Earlier discussion in this report concluded that local oxidation of $\mathrm{H}_{2} \mathrm{~S}$, which rises from thermal water at depth and enters perched ground water, explains the anomalous areal pattern and concentrations of $\mathrm{SO}_{4}$ in ground water in Cañon de San Diego.

Spring H-32 (plot B), near the caldera rim, displays a linear pattern similar to those for several Baca wells. Periodic mixing with dilute river water reduces the $\mathrm{Cl}$ content and thus explains the lower slope of the line. Despite its smaller $\mathrm{Cl}$ content, spring $\mathrm{H}-32$ water contains as much $\mathrm{SO}_{4}$ as water from many of the Baca well samples, believed to reflect local production of $\mathrm{SO}_{4}$.

The plot for spring H-6 at Soda Dam, shown by inset $\mathrm{C}$, is compared with that for Baca well water. After dilution, the spring water contains more $\mathrm{SO}_{4}$ than the Baca water in proportion to other constituents and as much as many of the other constituents. The mixed water evidently has received an appreciable $\mathrm{SO}_{4}$ input since the geothermal water left the caldera reservoir(s).

The water in spring H-32 and spring H-6 represents moderate and small modifications, respectively, of the reservoir fluid(s); the water in spring $\mathrm{H}-15$ at Jemez Springs, however, greatly differs with respect to $\mathrm{SO}_{4} / \mathrm{Cl}$ : the slope of the trend line (fig. 34 , inset $D$, solid line) indicates direct covariation of $\mathrm{SO}_{4}$ and $\mathrm{Cl}$ rather than inverse covariation as in plots $\mathrm{A}$, $\mathrm{B}$, and C. Direct covariation implies a much smaller input of $\mathrm{SO}_{4}$, if any at all, since the last major episode of dilution of the Jemez Springs. Local dilution, indicated by the dashed trend lines in figure 34D, is considered in subsequent discussion. 
B1

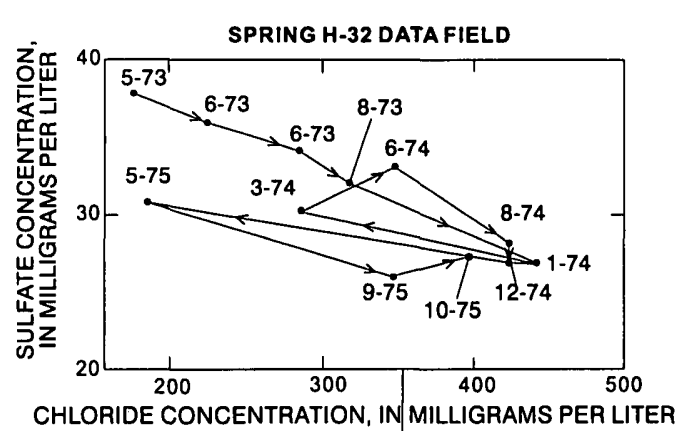

C

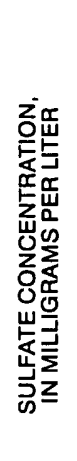

C1

SODA DAM DATA FIELD

SODA DAM DATA FIELD
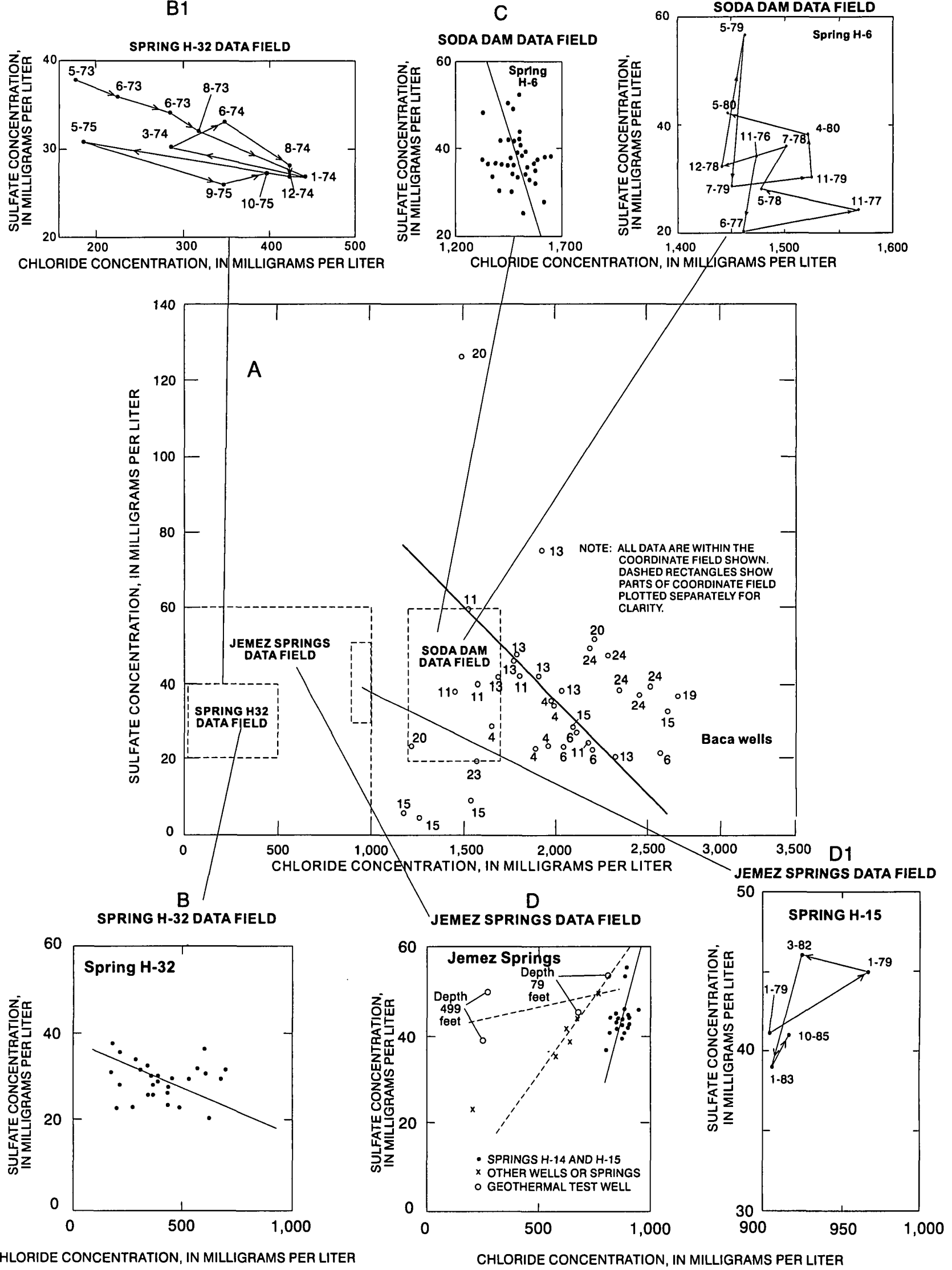

Figure 34.--Covariation of sulfate and chloride in reservoir fluids and in mineral water from the Valles Caldera and Cañon de San Diego (data from Purtymun and others, 1975, 1976, 1978, 1980a,b, and 1981; Trainer, 1978; White, 1986; and Shevenell and others, 1987). Wells and springs shown in figures 5 and 31. 
Siable Isoropes as Eviolence of Rlizing

Stable-isotope data also are valuable evidence of dilution and mixing of water. Isotopic and chloride data are listed in table 12, and the covariation of the stable isotopes deuterium and ${ }^{18} \mathrm{O}$ for fluid samples from geothermal reservoirs and Cañon de San Diego as far south as Jemez Springs is shown in figure 35. Data for wells GT-2, VC-1, VC-2A, and VC-2B also are shown in figure 35.

The deuterium content of rain and snow is temperature (and hence altitude) dependent; deuterium is lower at lower temperatures than at higher temperatures. Water becomes increasingly depleted in deuterium with increasing negative numbers. The ${ }^{18} \mathrm{O}$ content of water can be affected by several processes, two of which are significant in a geothermal environment: the exchange of oxygen between rock and fluid, with the fluid becoming enriched in ${ }^{18} \mathrm{O}$ (progressively smaller negative numbers), and evaporation (steam loss). The meteoric-water line shown in figure 35 was developed by Vuataz and Goff (1986, p. 1842), who used data for streams and for spring water of shallow circulation in the Jemez Mountains. Some groups of points for a single spring system show a linear distribution that defines the variation in the proportions of parent waters-a dilution trend line between a reservoir fluid and a point on the meteoric-water line. Lines for the Jemez Springs and Soda Dam water are shown in figure 35. The isotopic composition of a mixed water situated on a dilution line can be computed from its distances from the geothermal-fluid and meteoric-water end members and from their isotopic compositions. A second useful aspect of a dilution line is the approximate isotopic composition of an unknown geothermal parent fiuid. The dilution line for Jemez Springs, and perhaps that for Soda Dam water, supports geothermal parent fluids that are similar isotopically to the sample from well VC-2A in the Sulphur Springs reservoir (fig. 35).

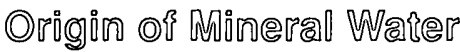

On the basis of published reports, investigators of the thermal waters in and near Valles Caldera believe that (1) mineral waters in Cañon de San Diego are derivatives of the geothermal-reservoir fluids and (2) the available data and understanding of the entire regional hydrologic system are inadequate for a determination of where and how the mixed water was formed. This situation may not change substantially in the future because prospects for further exploration for geothermal-energy development are uncertain and because much of the area is Federal, State, or Indian lands where other kinds of development are likely to be limited. For these reasons a general statement of origin, even if somewhat speculative, is desirable. The following discussion centers on three broad issues concerning mineral water: (1) the likely nature of a parent geothermal fluid; (2) possible source(s) of a dilute (mixing) water; and (3) the likely manner and place(s) of mixing. Because the mixed water is found in different geohydrologic settings for which different types or quantities of data are available, the discussion is organized by individual occurrences of mixed water.

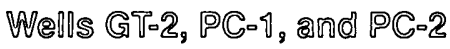

Goff and others (1988, p. 6049) suggested, on the basis of geographic proximity, that reservoir fluid from the Sulphur Creek area is the likely geothermal parent of derivative mixed water beneath the Jemez Plateau. This inference is supported by the analytical data for well GT-2.

Potential geothermal parent water for well GT-2 can be examined on the basis of chemical and stableisotope data (figs. 22 and 36, respectively). In figure 22 the linear distribution of chemical data suggests that either Baca (Redondo Creek) or Sulphur Creek reservoir water might be credible parent fluid(s), hence a Sulphur Creek geothermal parent, perhaps similar to the samples from wells VC-2A, VC-2B, or WC 23-4, is probable. (Two samples were collected from well WC $23-4$, at depths of 4,800 and $6,300 \mathrm{ft}$. Gorf and others (1992) suggested that the deeper sample represents pore fluid in the crystalline rock. Only the sample from $4,800 \mathrm{ft}$ is suggested here as a possible reservoir fluid.) Interpretation of the isotopic data (fig. 36) confirms the choice of Sulphur Creek fluid, but only well VC-2A, of the three samples available, could be a parent fluid because of the isotopic compositions of the parent geothermal and dilute waters.

The distribution of geothermal-fiuid samples in a commonly used plot of deuterium and ${ }^{18} \mathrm{O}$ is illustrated in figure 56. Points for geothermal water are right of the meteoric-water line, a shift explained by fractionation of oxygen through exchange between water and the hot rock through which it flows. Silicate minerals are richer in ${ }^{18} \mathrm{O}$ than meteoric water, so the exchange enriches the fluid in ${ }^{18} \mathrm{O}$ and shifts a point on the plot to a larger number (a smaller negative number). Isotopically, a dilute water would lie on or near the meteoric-water line in figure 36. 
Table 12. Isotopic and chloride data for mineral water from wells and springs at Jemez Springs and Soda Dam

[mg/L, milligrams per liter; --, no data. Data from Purtymun and others (1975, table II), Trainer (1978, tables 5, 8A, 8C), Vuataz and Goff $(1986$, table 1$)$, White (1986, tables 1,3$)$, and

Goff and others (1988, table 2; 1992, table 1)]

\begin{tabular}{|c|c|c|c|c|c|c|c|}
\hline \multirow{2}{*}{$\begin{array}{c}\text { Site } \\
\text { identifier } \\
\text { (figs. } 5 \\
\text { and 7) }\end{array}$} & \multirow[b]{2}{*}{ Source of sample } & \multirow{2}{*}{$\begin{array}{l}\text { Sample } \\
\text { number }\end{array}$} & \multirow[b]{2}{*}{ Date } & \multicolumn{2}{|c|}{ Stable isotopes } & \multirow{2}{*}{$\begin{array}{c}\text { Tritium } \\
\text { (tritium } \\
\text { units) }\end{array}$} & \multirow{2}{*}{$\begin{array}{c}\text { Chloride } \\
\text { (mg/L) }\end{array}$} \\
\hline & & & & $\delta \mathrm{D}$ (per mil) & $\overline{\delta^{18} \mathrm{O} \text { (per mil) }}$ & & \\
\hline & \multicolumn{7}{|c|}{ Jemez Springs } \\
\hline \multirow[t]{6}{*}{$\mathrm{H}-14$} & Travertine Mound & -- & $12-02-72$ & -82.1 & -10.52 & -- & 920 \\
\hline & & -- & $2-21-73$ & -- & -- & 6.4 & 880 \\
\hline & & VA-7 & $1-79$ & -83.6 & -11.30 & -- & 829 \\
\hline & & VA-66 & $12-80$ & -83.1 & -11.35 & -- & 910 \\
\hline & & VA-91 & 3-82 & -- & -- & 6.7 & 869 \\
\hline & & VA-123 & $1-83$ & -- & -- & 2.92 & 906 \\
\hline \multirow[t]{4}{*}{$\mathrm{H}-15$} & Main Spring & VA-10 & $1-79$ & -82.3 & -10.60 & -- & 904 \\
\hline & & VA-18 & $1-79$ & -81.4 & -10.40 & -- & 968 \\
\hline & & VA-93 & $3-82$ & -82.1 & -10.40 & -- & 926 \\
\hline & & -- & $10-04-85$ & -81.9 & -10.46 & - & 917 \\
\hline VA-92 & Buddhist Spring & VA-92 & $3-82$ & -83.6 & -11.05 & 10 & 617 \\
\hline VA-19 & $\begin{array}{l}\text { Geothermal well, } \\
80 \text {-foot depth }\end{array}$ & VA-19 & $1-79$ & -84.0 & -11.30 & -- & 705 \\
\hline VA-15 & $\begin{array}{l}\text { Geothermal well, } \\
500 \text {-foot depth }\end{array}$ & VA-15 & $1-79$ & -85.9 & -11.80 & -- & 243 \\
\hline VA-19 & $\begin{array}{l}\text { Geothermal well, at } \\
\text { well head }\end{array}$ & -- & $1-83$ & -- & - & 3.58 & 862 \\
\hline \multirow[t]{2}{*}{$\mathrm{H}-17$} & $\begin{array}{l}\text { Abandoned private } \\
\text { well }\end{array}$ & -- & $5-30-74$ & -85.2 & -11.42 & -- & 700 \\
\hline & \multicolumn{7}{|c|}{ Soda Dam } \\
\hline \multirow[t]{11}{*}{ H-6 } & Main Spring & -- & $12-01-72$ & -84.8 & -10.40 & & 1,500 \\
\hline & & -- & $2-21-73$ & -- & -- & 4.0 & - \\
\hline & & -- & $12-04-74$ & -- & -- & .4 & 1,460 \\
\hline & & VA-6 & 7-78 & -84.9 & -10.60 & -- & 1,480 \\
\hline & & VA-51 & $4-80$ & -85.4 & -10.70 & -- & 1,520 \\
\hline & & VA-64 & $4-80$ & -85.2 & -10.60 & -- & 1,560 \\
\hline & & VA-89 & 3-82 & -- & -- & 2.9 & 1,480 \\
\hline & & VA-99 & $9-82$ & -- & -- & 1.33 & 1,614 \\
\hline & & VA-109 & $1-83$ & -84.0 & -10.35 & 1.48 & 1,536 \\
\hline & & VA-132 & $5-83$ & -- & -- & 1.62 & 1,477 \\
\hline & & VA-140 & $2-01-84$ & -84.9 & -10.56 & -- & 1,480 \\
\hline VA-5 & Grotto Spring & VA-5 & 7-78 & -84.6 & -10.65 & -- & 1,480 \\
\hline \multirow[t]{3}{*}{$\mathrm{H}-6$} & Hidden Spring & VA-27 & $5-79$ & -84.9 & -10.95 & -- & 1,195 \\
\hline & & VA-90 & $3-82$ & -85.1 & -10.65 & 5.7 & 1,240 \\
\hline & & VA-110 & $11-83$ & -- & -- & 3.63 & 1,294 \\
\hline
\end{tabular}


Table 12. Isotopic and chloride data for mineral water from wells and springs at Jemez Springs and Soda Dam--Concluded

\begin{tabular}{|c|c|c|c|c|c|c|c|}
\hline \multirow{2}{*}{$\begin{array}{c}\text { Site } \\
\text { identifier } \\
\text { (figs. } 5 \\
\text { and 7) }\end{array}$} & \multirow[b]{2}{*}{ Source of sample } & \multirow{2}{*}{$\begin{array}{l}\text { Sample } \\
\text { number }\end{array}$} & \multirow[b]{2}{*}{ Date } & \multicolumn{2}{|c|}{ Stable isotopes } & \multirow{2}{*}{$\begin{array}{l}\text { Tritium } \\
\text { (tritium } \\
\text { units) }\end{array}$} & \multirow{2}{*}{$\begin{array}{c}\text { Chloride } \\
\text { (mg/L) }\end{array}$} \\
\hline & & & & $\delta \mathrm{D}$ (per mil) & $\delta^{18} \mathrm{O}$ (per mil) & & \\
\hline \multirow[t]{5}{*}{ H-6 } & Jemez River above & -- & $4-80$ & -94.4 & -13.20 & -- & 4.0 \\
\hline & Soda Dam & -- & $3-82$ & -89.5 & -12.50 & 13 & 19.5 \\
\hline & & - & $1-83$ & -- & -- & 11.8 & 10.3 \\
\hline & & -- & $5-83$ & -85.4 & -12.00 & 32.6 & 11.3 \\
\hline & \multicolumn{7}{|c|}{ Wells in Redondo Creek reservoir(s) } \\
\hline \multirow[t]{3}{*}{4} & Baca 4 & -- & $7-09-81$ & -86 & -10.21 & -- & -- \\
\hline & & -- & $7-09-81$ & -87 & -10.23 & -- & -- \\
\hline & & -- & $7-02-82$ & -86 & -10.4 & .49 & 1,981 \\
\hline \multirow[t]{5}{*}{13} & Baca 13 & -- & $3-30-81$ & -90 & -10.19 & - & -- \\
\hline & & -- & $8-12-81$ & -87 & -10.23 & - & -- \\
\hline & & -- & 8-13-81 & -89 & -10.34 & - & -- \\
\hline & & -- & $6-04-82$ & -86 & -10.0 & -- & 1,897 \\
\hline & & -- & $7-01-82$ & -83 & -10.2 & -- & 2,019 \\
\hline 15 & Baca 15 & -- & $9-08-82$ & -84 & -8.7 & .22 & 2,093 \\
\hline 19 & Baca 19 & -- & 9-08-82 & -82.2 & -8.7 & .47 & 2,678 \\
\hline \multirow{2}{*}{20} & Baca 20 & 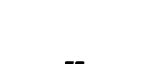 & $10-82$ & -83.1 & -8.41 & .47 & $\begin{array}{l}2,665 \\
2,207\end{array}$ \\
\hline & Daca $\angle 0$ & -- & $10-25-80$ & $\begin{array}{l}-87 \\
-86\end{array}$ & $\begin{array}{l}-9.21 \\
-8.47\end{array}$ & - & $\begin{array}{r}2,207 \\
--\end{array}$ \\
\hline \multirow[t]{5}{*}{24} & Baca 24 & -- & $8-13-81$ & -85 & -9.48 & -- & -- \\
\hline & & -- & $8-13-81$ & -85 & -9.48 & -- & -- \\
\hline & & -- & $7-15-82$ & -79 & -8.90 & .91 & -- \\
\hline & & -- & $7-16-82$ & -- & - & -- & 2,458 \\
\hline & \multicolumn{7}{|c|}{ Wells in Sulphur Creek reservoir } \\
\hline VC-2A & $\mathrm{VC}-2 \mathrm{~A}$ & -- & $8-27-87$ & -74.4 & -7.1 & .47 & 2,943 \\
\hline VC-2B & VC-2B & VC2B-90 & $1-17-90$ & -85.2 & -7.5 & .77 & 4,150 \\
\hline WC 23-4 & WC $23-4$ (4,800 feet) & VA-113 & $1-04-83$ & -80.4 & -7.80 & -- & 4,350 \\
\hline
\end{tabular}

${ }^{1}$ Sample numbers from Goff and others $(1988,1992)$. 


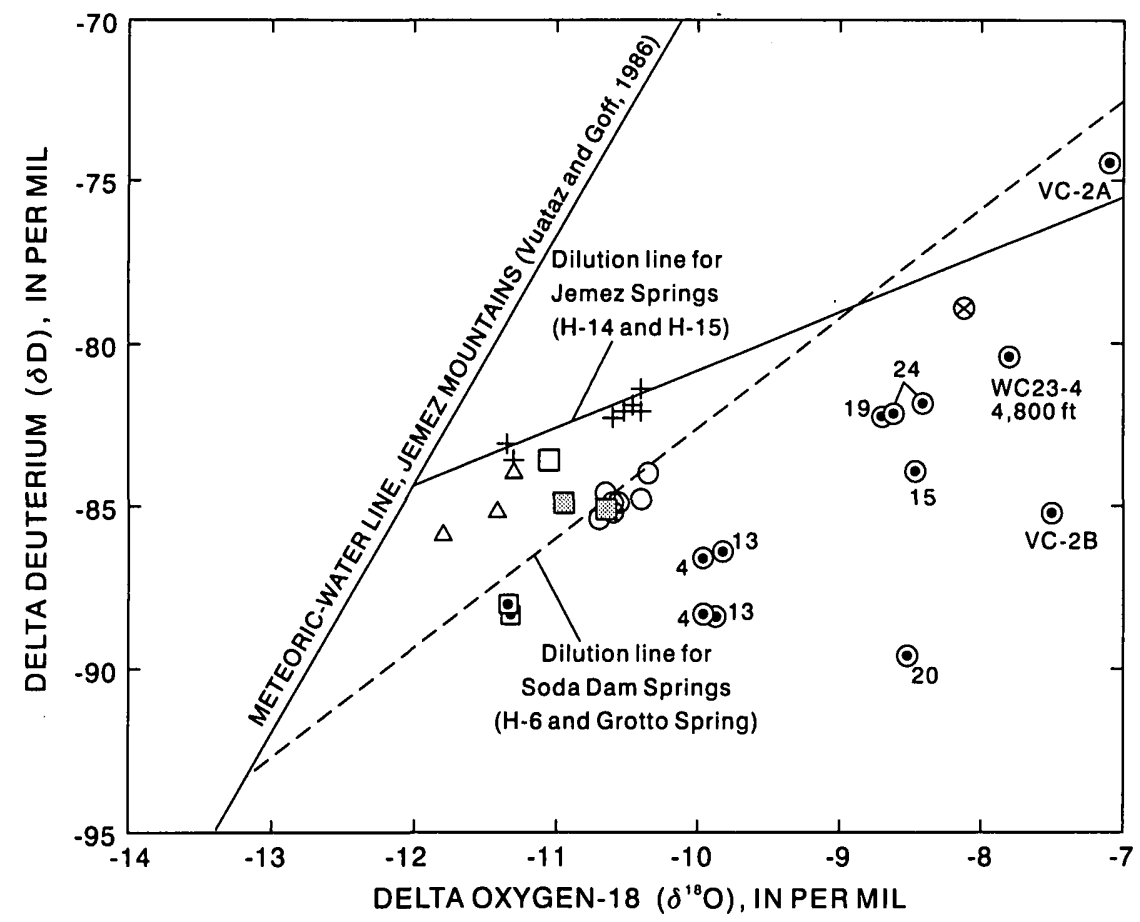

EXPLANATION

O RESERVOIR SAMPLE-- Baca wells identified by number only

+ SPRINGSH-14 ANDH-15AT JEMEZ SPRINGS

$\triangle$ GEOTHERMAL TEST WELL VA-15 AND WELL H-17 AT JEMEZ SPRINGS

$\square$ BUDDHIST SPRINGAT JEMEZ SPRINGS, VA-92

O SPRING H-6 AND GROTTO SPRING, VA-5 AT SODA DAM

I HIDDEN SPRING AT SODA DAM, VA-27

@ WELLVC-1

( WELL GT-2

Figure 35.--Covariation of deuterium and oxygen-18 in Valles Caldera reservoir fluids and in derivative mixed waters (data from Trainer, 1978; Truesdell and Janik, 1986; Vuataz and Goff, 1986; White, 1986; Shevenell and others, 1987; and Goff and others, 1988 and 1992). Well and spring locations shown in figures 5,7 , and 31 .

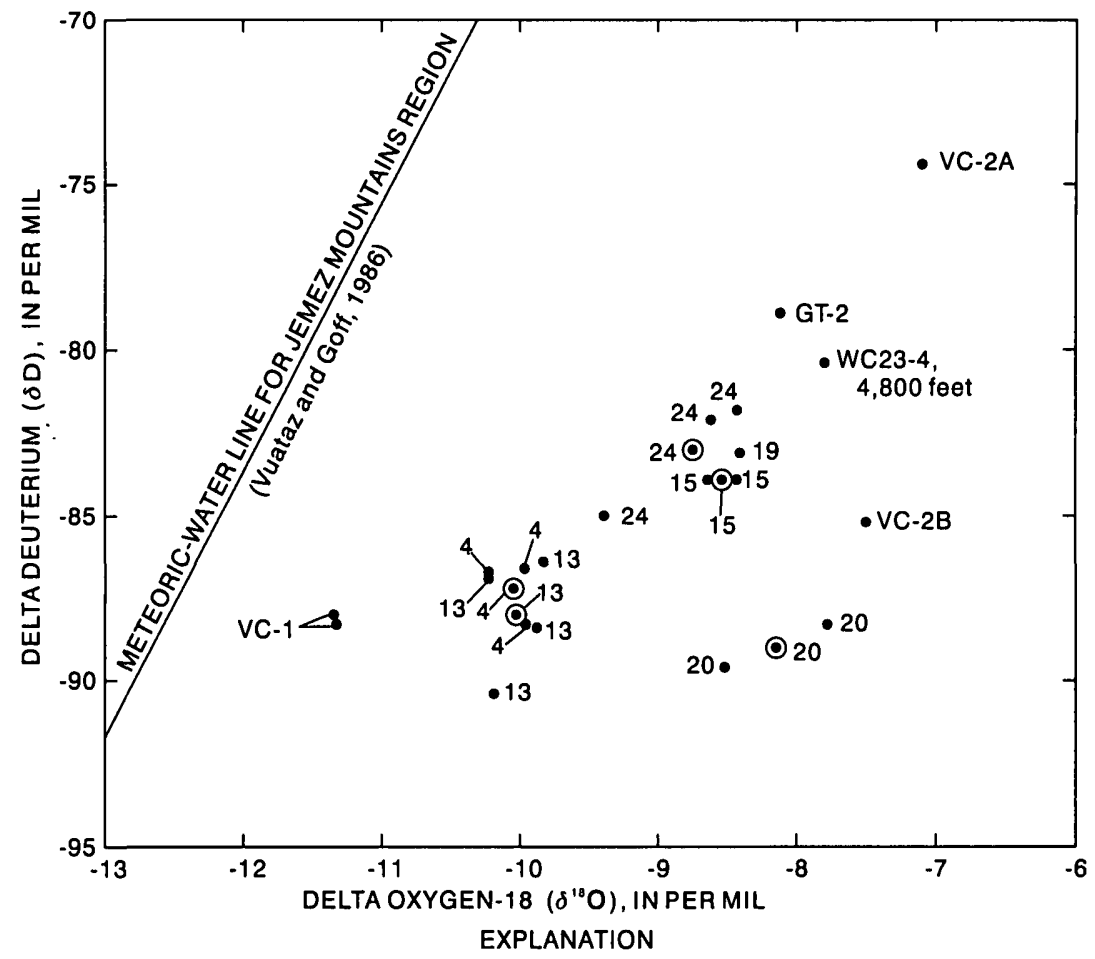

O AVERAge of SEVERAL SAMPLES SHOWN

Figure 36.--Covariation of deuterium and oxygen-18 in water from geothermal wells in Valles Caldera and wells VC-1 and GT-2 near the caldera rim (data from Trainer, 1978, table 8C; Truesdell and Janik, 1986, table 3; Goff and others, 1988, table 2, and 1992, table 1). Well locations shown in figure 5. 
Based on regional geohydrology, two aquifers are the likely sources of the dilute parent of the fluid in well GT-2. The first and more probable source, because well GT-2 is very near the rim of the caldera, is alluvium in the moat, recharged by infiltration from San Antonio Creek. In such a setting dilute water is thought to percolate downward to mix with laterally escaping reservoir fluid, with the resultant mixture moving into sedimentary strata of the Jemez Plateau, where the strata abut ring-fracture faults. Observations made during drilling of test holes showed the presence of cavernous zones near the base of the limestone. During normal ground-water circulation, such zones would have been opened along favorable joints and bedding-surface openings before the caldera was formed. The zones probably were later selectively enlarged, at and below the water level in flow channels from the reservoir, by the $\mathrm{CO}_{2}$-rich thermal fluid.

The second likely source of the dilute parent of the fluid in well GT-2 is ground water in perched zones in the section of volcanic and sedimentary rocks. Such zones were not identified during construction of well GT- 2 because caving problems dictated rapid drilling, but one zone in volcanic rocks in a well drilled at the Fenton Hill site (fig. 10) for water supply (Becker and others, 1981) seems to have a continuing yield adequate to provide for the perennial flow of mixed water. Wells PC-1 and PC-2 (fig. 5) penetrate a volcanic and sedimentary section similar to that penetrated by well GT-2, and both pass through perched saturated zones containing dilute water. Some of these zones in lower Abo Formation and upper Madera Limestone rocks yield slightly mineralized water that may be very dilute mixtures of native ground water and geothermal fluid. Well PC-1, which extends completely through the sedimentary rocks into the underlying gneiss, also penetrates several wateryielding zones in the lower part of the limestone that yield mineral water similar to that in well VC-2A. Thus, although what may be very dilute mixtures are found far up in the section, the true mineral water is in the basal limestone as it is in well GT-2. As can be seen in figure 37 , these deeper waters for PC-1 are more mineralized (less diluted) with increasing depth. Well records do not establish the five sampled horizons near the bottom of PC-1 as hydraulically separate wateryielding zones, but assuming that they are separate zones is reasonable; one was identified as a fracture and one as a cavernous zone (Shevenell and others, 1988, p. 16). The stacked nature of the assemblage indicates probable stratigraphic control of water-yielding zones, in contrast to the strong structural control evident in hole VC-1. The stepwise-upward increase in degree of dilution suggests inflow of dilute water from above, wherever the dilution occurred, and the deeper and presumably more effectively isolated zones experiencing the least dilution.

Perched water-yielding zones in sedimentary rocks beneath Jemez Plateau are thought to be recharged by (1) infiltration through the beds of small streams on the plateau, many of which carry water only during and shortly after storms or (2) lateral flow into the sedimentary strata from ground water in the moat, as outlined in the discussion of well GT-2.

Stable-isotope data are unavailable for water in San Antonio Creek near the Fenton Hill site or for perched ground water beneath the Jemez Plateau. Reasonable estimates for San Antonio Creek can be based on analyses for the creek in its upper reaches in Valle Toledo and for San Antonio Hot Spring, which flows into the creek: -90.0 to -93.0 per mil for deuterium and -12.65 to -12.85 per mil for ${ }^{18} \mathrm{O}$. Isotope values for perched water that infiltrates from the plateau surface can be estimated from a plot by Vuataz and Goff (1986, fig. 5); for the altitude of the Fenton Hill site they are -85.0 per mil for deuterium and -12.1 per mil for ${ }^{18} \mathrm{O}$. The addition of a dilute water of such isotopic character to any of the reservoir fluids would shift the point for the reservoir fluid down and to the left in the plot in figure 36 . Of the samples shown, only water from VC-2A could mix with the inferred dilute water to yield a combination like that in GT-2.

Once likely geothermal and dilute parent water has been identified, the result of its hypothetical mixing can be calculated with a simple balance equation (Trainer, 1975, p. 215):

$$
\begin{gathered}
\left(\operatorname{vol}_{\mathrm{gt}} \times \operatorname{conc}_{\mathrm{gt}}\right)+\left(\operatorname{vol}_{\mathrm{dil}} \times \operatorname{conc}_{\mathrm{dil}}\right)= \\
\left(\operatorname{vol}_{\mathrm{gt}}+\operatorname{vol}_{\mathrm{dil}}\right)\left(\operatorname{conc}_{\mathrm{mix}}\right)
\end{gathered}
$$

where

$$
\begin{aligned}
& \text { vol }_{\mathrm{gt}}=\text { volume of geothermal fluid; } \\
& \text { conc }_{\mathrm{gt}}=\text { concentration of a selected } \\
& \text { constituent in the geothermal } \\
& \text { fluid; } \\
& \text { vol }_{\text {dil }}=\text { volume of the diluting fluid; } \\
& \text { conc }_{\text {dil }}=\text { concentration of the same } \\
& \text { selected constituent in the } \\
& \text { diluting water; and } \\
& \text { conc }_{\text {mix }}=\text { concentration of the same } \\
& \text { selected constituent in the } \\
& \text { mixed (resultant) water. }
\end{aligned}
$$



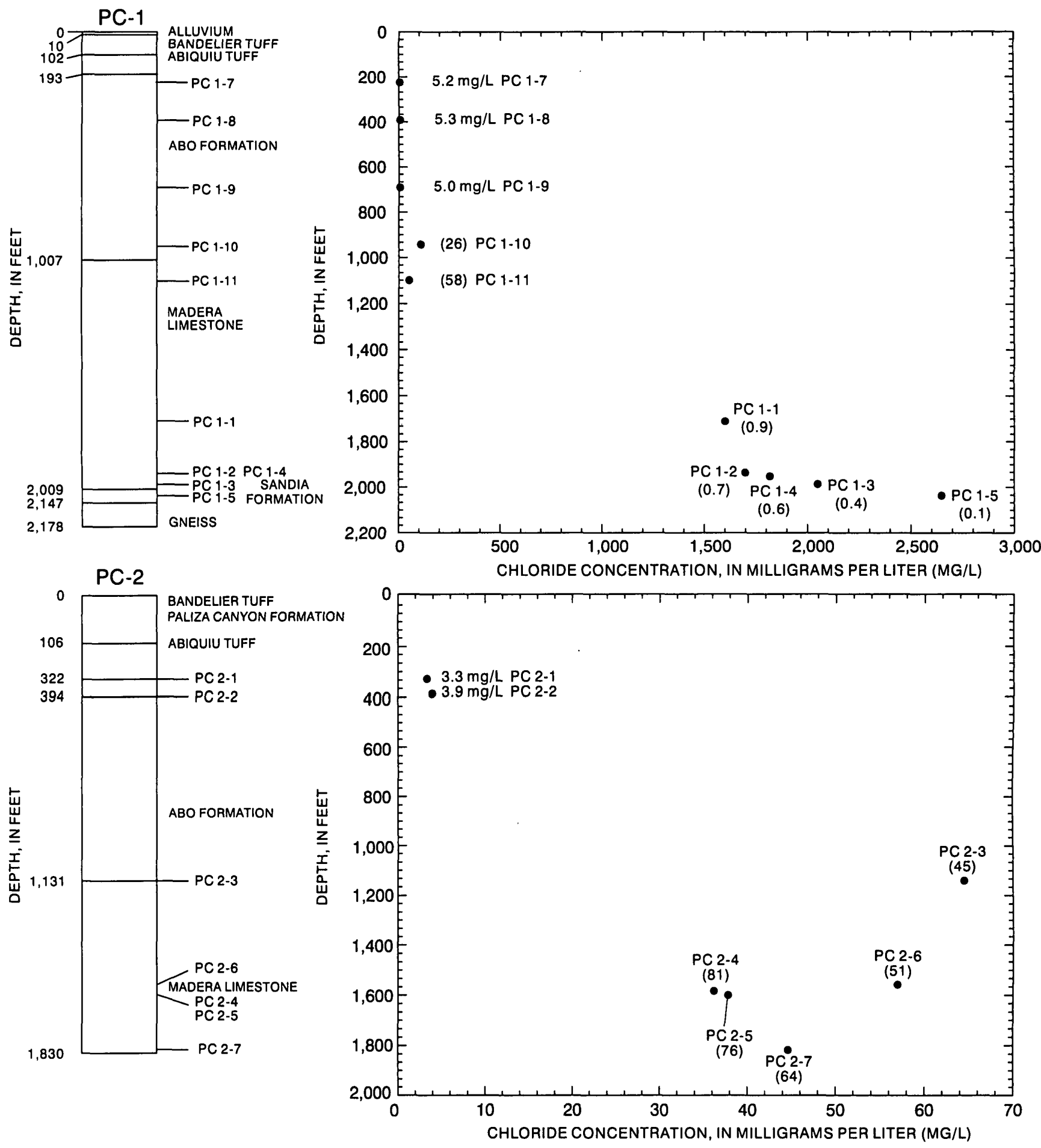

EXPLANATION

PC 2-7 APPROXIMATE DEPTH WHERE SAMPLE WAS COLLECTED

- (64) CALCULATED VOLUME OF DILUTE WATER THAT, WHEN MIXED WITH ONE VOLUME OF RESERVOIR FLUID, YIELDS WATER LIKE THAT IN WELL VC-2A--Calculation based on chloride analysis

Figure 37.--Concentration of chloride in samples from water-yielding zones penetrated by wells PC-1 and PC-2 (data from Shevenell and others, 1987, tables B-I and B-II, and 1988, p. 36-40). Well locations shown in figure 5. 
If the dilute water has concentrations of constituents near zero and if a unit volume of geothermal fluid is assumed, the equation simplifies to:

$$
\begin{aligned}
\text { conc }_{\mathrm{gt}} & =\text { conc }_{\text {mix }}+\left(\text { vol }_{\mathrm{dil}} \times \text { conc }_{\text {mix }}\right), \text { or } \\
\text { vol }_{\mathrm{dil}} & =\frac{\text { conc }_{\mathrm{gt}}-\text { conc }_{\text {mix }}}{\text { conc }_{\text {mix }}}
\end{aligned}
$$

Use of this equation assumes that indicator-constituent ratios are preserved during dilution and mixing.

Calculation of mixing volumes using analytical data for wells GT-2 and VC-2A (GT-2, $25 \mathrm{mg} / \mathrm{L} \mathrm{Li}$ and 25 $\mathrm{mg} / \mathrm{L} \mathrm{B}$; VC-2A, $26.5 \mathrm{mg} / \mathrm{L} \mathrm{Li}$ and $25.6 \mathrm{mg} / \mathrm{L} \mathrm{B}$, table 6) results in estimates of 0.06 unit volume dilute water (using $\mathrm{Li}$ ) and 0.02 unit volume dilute water using $\mathrm{B}$ for a unit volume of fluid from well VC-2A.

Isotopic analyses for wells VC-2A and WC 23-4 were used with assumed values for water in San Antonio Creek near the Fenton Hill site to calculate shifts along dilution lines produced by mixing the reservoir fluids with small volumes of dilute water (fig. 38). Well VC-2A yields the better fit, and agreement with the chemistry-based calculation of mixing volumes is fairly good. Taken together these independent arguments indicate that well GT-2 water is nearly as concentrated as its reservoir parent and that the parent water resembles VC-2A but is somewhat more mineralized and depleted in deuterium.

Mixing volumes calculated for samples from wells PC-1 and PC-2 (fig. 37) range from very large dilute contributions in perched water zones higher in the sedimentary section to mixtures in the basal limestone (PC-1) that approach the component ratio calculated for GT-2 water. The part of the Jemez Plateau that includes wells GT- 2 and PC- 1 is small and the regional significance of these two occurrences of mineral water cannot be estimated. It is of interest, however, that both wells that completely penetrate the sedimentary section in the plateau, where stratigraphic control of ground-water flow patterns may be greater than structural control, penetrated mineral-water conduits.

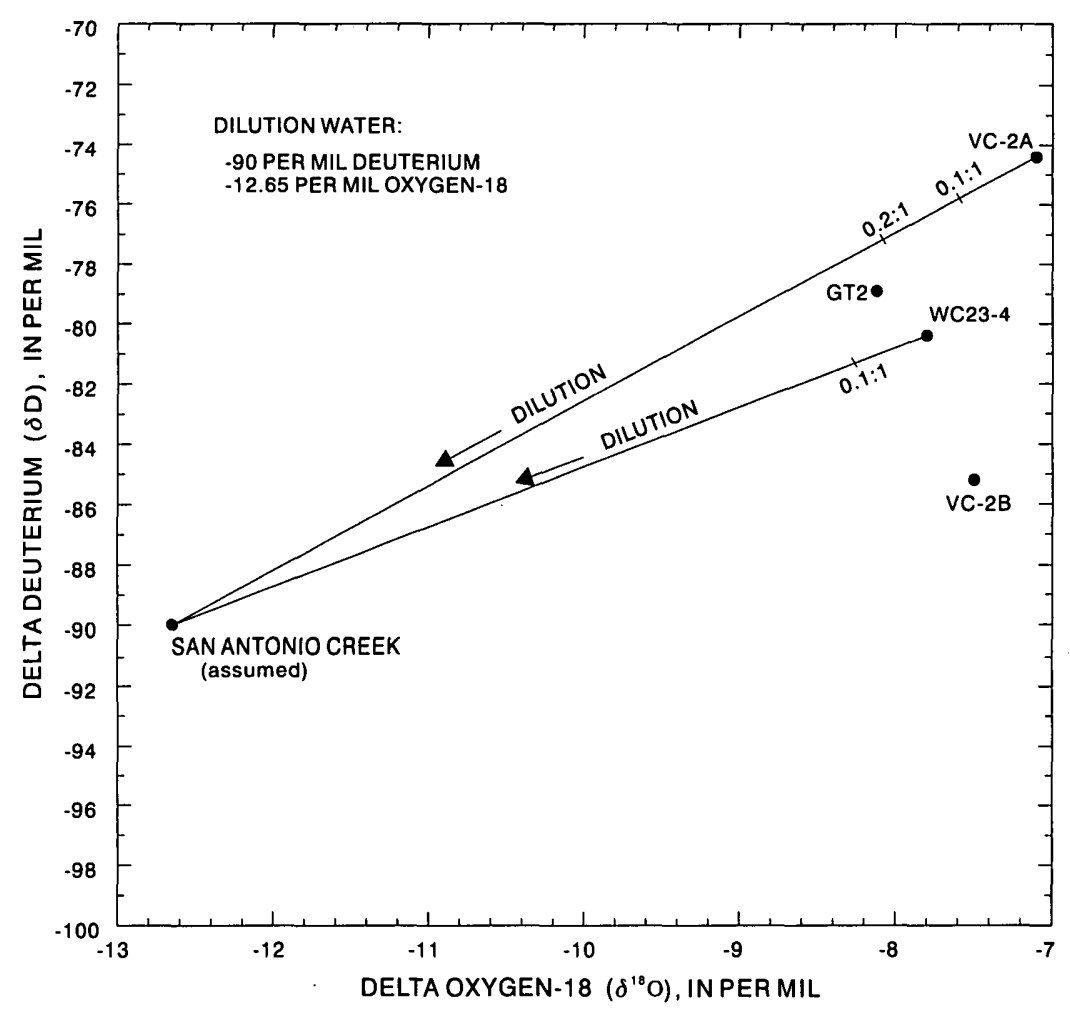

Figure 38.--Effect on stable-isotope composition of geothermal-reservoir fluid from addition of small volumes of a hypothetical dilute water to one volume of reservoir water (data from Trainer, 1978, table 8C; and Goff and others, 1988, table 1). Well locations shown in figure 5 . 


\section{Well VC-1}

The chemical and stable-isotope approaches applied to well GT-2 water were used to estimate the dilution ratio for mineral water in well VC-1 and to consider hypothetical parent reservoir water. The reservoir samples used in the calculations represent the six wells in the Redondo Creek field for which isotopic and extensive chemical data are available (Baca wells $4,13,15,19,20$, and 24). Six sets of chemistry-based estimates were made, each using three indicator constituents in water from well VC-1 and from one reservoir (Baca) well. Agreement of values is reasonable within each set. Similar estimates based on isotopic data also are internally consistent but different from those based on chemistry. The isotopic approach is useful in reinforcing the conclusion drawn by Vuataz and Goff (1986, p. 1847) that no single reservoir fluid and no single dilute fluid are parents of all derivative water outside the caldera.
Chemical and isotopic analyses are available for two water-yielding zones in well $\mathrm{VC}-1$, at 1,585 and $1,760 \mathrm{ft}$ below land surface and both within Madera Limestone (table 13) (Goff and others, 1988, table 2). The waters are very similar; the following discussion is based on water from the upper zone. Mixing volumes calculated from concentrations of $\mathrm{Li}, \mathrm{B}$, and $\mathrm{Cl}$ in $\mathrm{VC}-1$ water are listed and summarized in table 14. These estimates range from 0.5 to 1.8 volumes of dilute water per unit volume of reservoir fluid. Isotopic data were used to calculate the dilution required to produce a given shift in isotopic composition along the dilution trend line from the isotopic composition in a geothermal well to that at a hypothetical source of dilute water (fig. 39). The estimates are similar to but somewhat larger than those from the indicator constituents, which range from 1 to 2.2 volumes of dilute water.

Table 13. Chemical and stable-isotope data for well VC-1

[Well location shown in figure 5. Ionic concentrations in milligrams per liter; isotope compositions in per mil $(\% / 00)$ notation. Data from Truesdell and Janik $(1986$, tables 1,3$)$, White $(1986$, tables 1,3$)$, and Goff and others (1988, table 2)]

\begin{tabular}{|c|c|c|c|c|c|c|c|c|c|c|c|c|}
\hline Well depth & $\mathrm{Ca}$ & Mg & $\mathbf{N a}$ & $\mathbf{K}$ & $\mathbf{L i}$ & $\mathrm{HCO}_{3}$ & $\mathrm{SO}_{4}$ & $\mathrm{Cl}$ & $\mathbf{F}$ & B & $\begin{array}{c}\delta D \\
(\% / 00)\end{array}$ & $\begin{array}{l}\delta^{18} O \\
(\% / 00)\end{array}$ \\
\hline $\begin{array}{l}\text { VC-1 at } 1,585 \\
\text { feet below } \\
\text { land surface }\end{array}$ & 49 & 17.8 & 883 & 85 & 8.00 & 942 & 56.8 & 964 & 3.94 & 8.55 & -88.0 & -11.35 \\
\hline $\begin{array}{l}\text { VC-1 at } 1,760 \\
\text { feet below } \\
\text { land surface }\end{array}$ & 47.8 & 11.9 & 804 & 84 & 7.27 & 919 & 74 & 853 & 4.74 & 10.1 & -88.3 & -11.33 \\
\hline
\end{tabular}




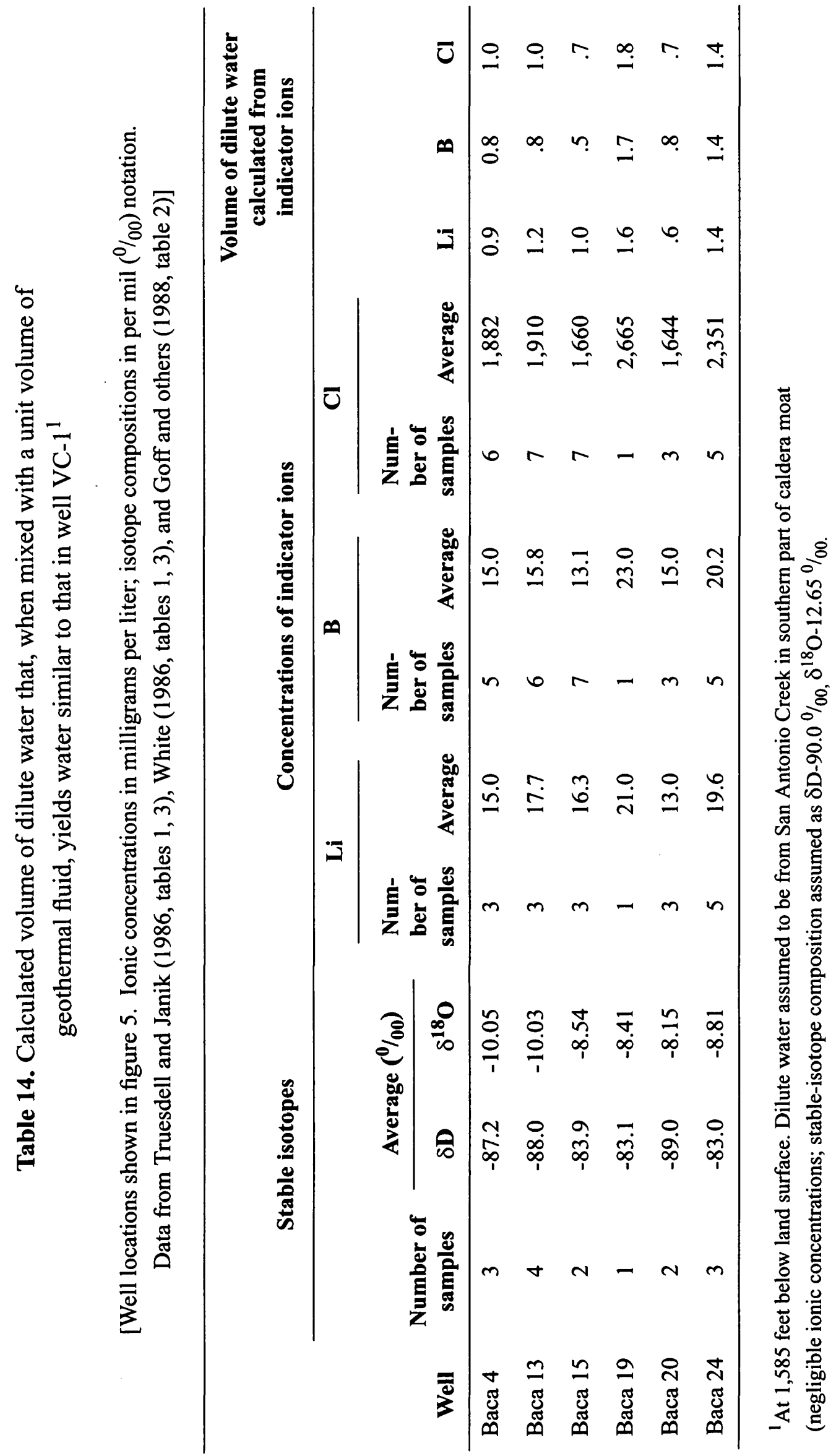




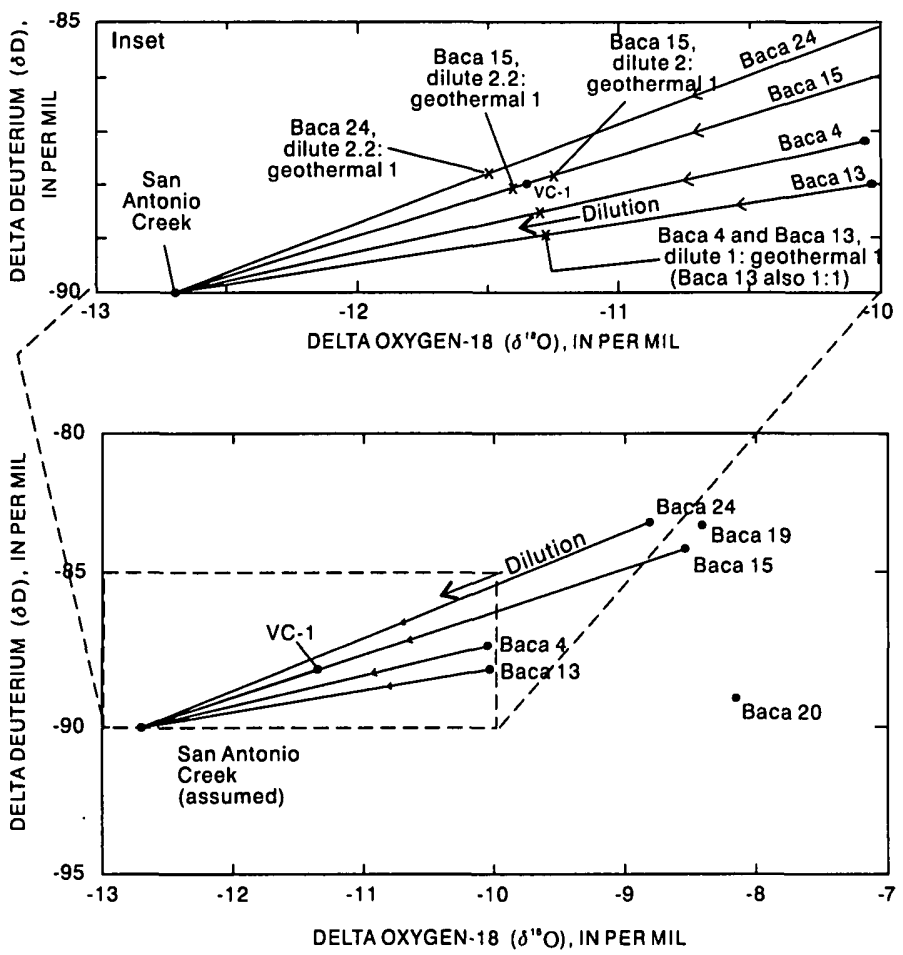

Figure 39.-- Formation of mineral water similar to that in well VC-1 (at 1,585 feet below land surface calculated from stable-isotope data for inferred dilute water and geothermal-reservoir fluid(data from Truesdell and Janik, 1986, table 3; and White, 1986, table 3). Lower plot shows hypothetical trend lines for progressive dilution; trend lines for other wells omitted for clarity. Upper plot shows examples of dilution ratios on four trend lines. Well locations shown in figure 5.

As was noted earlier, the three-dimensional complexity of Redondo Creek reservoir rocks and the wide range in character of its geothermal water became evident in the early 1980's when the release of proprietary data and extensive flow testing of several Baca wells provided geologic, hydrochemical, isotopic, temperature, and hydraulic data. Reservoir rocks beneath the Redondo dome were found to be highly compartmented by faults and stratigraphy (Nielson and Hulen, 1984). Scarcity of interference effects among wells during production tests suggests that many pairs of adjacent compartments are poorly interconnected hydraulically. Considerable variability in geothermal fluid was present from well to well. Several investigators (Smith and Kennedy, 1985; Truesdell and Janik, 1986, p. 1829-1832; and White, 1986, p. 1864) recognized the presence of two distinct waters; Goff and others (1988, p. 6046) recognized three if the Sulphur Creek reservoir is included. Differences among several interpretations have not been resolved, but in the Redondo Creek reservoir the fluids in Baca wells 4 and 13 differ substantially from those in Baca wells 15, 19, and 24 (Truesdell and Janik, 1986, p. 1829). Among numerous differences, fluid in Baca wells 4 and 13 is light isotopically and has lower salinity, higher temperature, and larger concentrations of $\mathrm{CO}_{2}$ and $\mathrm{He}$; fluid in Baca 15, 19, and 24 is heavier isotopically and has higher salinity, lower temperature, and smaller concentrations of $\mathrm{CO}_{2}$ and $\mathrm{He}$.

Concentrations of such conservative trace constituents as $\mathrm{Li}$ and $\mathrm{B}$ vary from one well to another, in much the same way as $\mathrm{Cl}$ concentrations. (See tables 4,6 , and 12 for examples of data and fig. 5 for areal distribution of the wells.)

Several of these differences are reflected in the estimates of mixing volume (table 14) and in the isotopic compositions shown in figure 39. If the two sets of mixing estimates and the areal distribution of isotopic composition are considered together, samples from Baca wells 4, 13, and perhaps 15 are the most likely representatives of parent fluids for water in well VC-1. Baca wells 4 and 13 best agree with the mixing 
estimates but are not adequate in themselves; one or both together would require the addition of water more enriched in deuterium. If the choice is limited to the Baca wells because of their proximity to well VC-1 (Goff and others, 1988, p. 6049) and both the mixing estimates and geographic distribution of the wells are considered (fig. 5), the situation shown in figure 39 is best explained by a parent water similar to some combination of waters from Baca wells 4 and (or) 13 and from 15 and (or) 24 .

For purposes of computation, any water that contains small concentrations of the indicator constituents can be selected for a hypothetical dilute water. The difficulty in selection of a dilute water for the mixing calculation, however, is two-fold and arises from the regional geohydrology. First, the dilute mixing member must be available perennially at a flow rate adequate to sustain the continuing flow of derivative water. Second, the only credible source for dilute parent water is perched ground water because the parent reservoir fluid comes from the principal or regional aquifer, far below the surface near the rim of the caldera. However, most bodies of perched water in this region are known to have small rates of yield and limited amounts of water in storage. Adequate yield supports the hypothetical stream-related aquifer as discussed for wells GT-2 and VC-1. A second credible source of dilute water for well VC-1 is ground water in the near-surface rhyolite, perched above the Abo Formation. As noted earlier, a number of warm springs in and near the ring-fracture zone yield dilute water. The largest are San Antonio Hot Springs (P12), Spence Springs (H42), and McCauley Spring (H39), the latter two of which are near well VC-1 (fig. 5). One of these flow systems, or another similar to them, is a more credible source of dilute water for well VC-1 fluid; they all have adequate perennial flow, and their isotopic composition is in the range that explains the VC-1 fluid.

Although a caldera source is well established for many principal constituents in the mineral water in Jemez Plateau and in and near Cañon de San Diego, there is as yet no compelling evidence to show precisely how and where geothermal fluid escapes from the caldera. Discussion in an earlier paragraph favors movement of fluid from the Sulphur Creek subsystem into the sedimentary section beneath the Jemez Plateau near wells GT-2 and PC-1. The further course of that fluid has not been established, but the possibility of southeastward flow beneath the plateau, to Cañon de San Diego, needs examination. Nearer the Jemez Fault Zone, electrical resistivity soundings
(Jiracek, 1974, 1975; Jiracek and others, 1975) suggest a gap in the ring-fracture intrusives near the site where San Antonio Creek flows out of the caldera. The proximity of this site to the fault zone, which extends along Cañon de San Diego and presumably influenced its formation, provides a logical general explanation for escape of reservoir fluid downcanyon in the subsurface. This hypothesis is consistent with the conceptual model of flow from the caldera and through the Jemez Fault Zone developed by Goff and others (1992, p. 193). As noted earlier, fumaroles and associated hydrologic phenomena in Cañon de San Diego outside the rim of the caldera near Battleship Rock indicate geothermal-fluid conduits at depth. Synthesis of thermal data for deep wells in the Jemez Plateau-Cañon de San Diego area (Goff and others, 1988, p. 6043) suggests that as much as half the subsurface discharge from the caldera may flow along the Jemez Fault Zone.

\section{Jemez Springs and Soda Dam}

Earlier discussion noted both significant similarities and differences between the mineral water at Jemez Springs and at Soda Dam. Despite geochemical signatures indicating that both are derivatives of geothermal-reservoir fluids and the geographic proximity of the springs, the water differs significantly. The water at Jemez Springs is hotter but carries a much smaller dissolved-solids load, although its content of $\mathrm{SO}_{4}$ is out of proportion to the rest of its mineral content. The two groups of springs may drain different conduit systems, which are isolated from one another and differ in size and shape. Further, the differences between the two groups of springs may be related to two aspects of mixing - the nature of the dilute water and the location of the mixing site.

Potential sources of dilute water for the mixing process have not been examined critically in published discussions of the mineral water. Local ground water along the route of escape of geothermal fluid into and through the rocks outside the caldera has been assumed to provide an adequate source of the dilute water. In discussions of wells GT-2 and VC-1, the dilute water was assumed to be ground water that had infiltrated from streams in the moat or from perched aquifers above conduits for the escaping geothermal fluid. This assumption was based in part on proximity and in part on the realization that there may be few places, except near infiltrating streams and the few known extensive perched aquifers, where dilute ground water is available in the quantities needed (approximately 50- 
$100 \mathrm{gal} / \mathrm{min}$ ). This conclusion is discussed in the next section of this report.

A source beneath the moat within the caldera is thought to be a likely dilute mixing member for Jemez Springs water. It offers not only a supply of adequate volume and rate of flow but one of moderately high temperature $\left(100-150^{\circ} \mathrm{C}\right.$; see Goff and others, 1986 , fig. 5). Direct covariation of $\mathrm{SO}_{4}$ and $\mathrm{Cl}$ in the Jemez Springs water (fig. 34D) implies that little $\mathrm{SO}_{4}$ is added to the water after the last major stage of mixing; hence, the dilute water (1) brought most of its $\mathrm{SO}_{4}$ load to the site of that last mixing or (2) gained it there. Part of the $\mathrm{SO}_{4}$ load in a mixed water is inherited from the parent geothermal fluid, and part may have been generated from $\mathrm{H}_{2} \mathrm{~S}$ along the flow path. A third potential source of $\mathrm{SO}_{4}$ is Sulphur Creek, which drains the Sulphur Springs area and joins San Antonio Creek upstream from where the creek flows out of the caldera (fig. 6). Sulphur Creek carries away much of the mineral matter emitted by the springs; one sample from Sulphur Creek at its mouth contained $200 \mathrm{mg} / \mathrm{L} \mathrm{SO}_{4}$ (Trainer, 1978, table 6). Part of the dissolved load in Sulphur Creek is diverted to and stored in the local ground-water reservoir in alluvium within the moat, and if groundwater storage in that reservoir is sufficiently large it may provide a substantial source of water (containing the requisite dissolved $\mathrm{SO}_{4}$ ) for the dilution of escaping geothermal fluid. No data are available to test this hypothesis.

Two factors could contribute to the effective maintenance of temperature over a flow distance of several miles (presumably a distance similar to that in which Soda Dam water has lost much more heat). Contributing water could have high temperatures at the site of mixing, and flow conduits to Jemez Springs could be of a type that minimizes heat loss during transport.

Water like that in the well VC-1 sample meets the requirements for the less mineralized mixing water in the last-stage dilution of Soda Dam water: Soda Dam and VC-1 waters are similar in terms of their strontium isotopes (Vuataz and others, 1988, table 2); they are also of similar composition, but the Soda Dam water has larger constituent concentrations. Additionally, if the last stage(s) of mixing to form Soda Dam water occurred in Cañon de San Diego, the loss of heat indicated at Soda Dam is largely explained by the moderate to low temperature of the "dilute" member(s) (approximately $100^{\circ} \mathrm{C}$ near the caldera rim, less than $50^{\circ} \mathrm{C}$ farther downcanyon).

Trainer (1984) inferred from the large total volumes of limestone removed from the conduit systems that the conduits are likely larger and more conductive than required for transport of the modest quantities of water now discharged by the springs. From this argument and from inference of rapid pressure transmission and slow mass transport in the conduits, Trainer (1984) concluded that the conduit systems contain large quantities of confined water in transient storage, with fluctuations in discharge governed by fluctuations in prevailing head.

\section{GROUND-WATER SYSTEM}

\section{Principal Aquifers}

Several lines of evidence noted in earlier sections reveal the presence of diverse ground water and aquifers in this region. At least two principal or regional aquifers are within the southwestern Jemez Mountains: one is the rift-fill sediments at the southern edge of the study area and the other is the geothermal reservoir(s) in Valles Caldera and their outflow conduits. There are at least three types of perched bodies of ground water: (1) those, commonly in volcanic rocks, that overlie the relatively impermeable Abo Formation; (2) those in permeable sedimentary strata that overlie less permeable beds within the sedimentary section, as in wells PC- 1 and PC- 2 or in Cañon de San Diego near the caldera rim; and (3) those in small, disconnected bodies of material that overlie less permeable rocks, as in parts of the ring-fracture moat within the caldera or in alluvial deposits that are in hydraulic connection with the Jemez River along part of its course. The third type is small and not of regional importance. Consequently, this is not discussed further in the report.

The geohydrologic nature of the rift-fill sediments at the southern edge of the study area, between San Ysidro and Bernalillo (fig. 1), is not well known. However, it is presumed to be similar to that in the explored part of the Albuquerque Basin, where thickness is measured in thousands of feet and hydrologic properties are governed by the sedimentary and stratigraphic nature and structure of the deposits.

The hot-water system beneath the central and western areas of the Valles Caldera is considered the principal or regional aquifer in the caldera because it extends to depths of at least several thousand feet and perhaps as far as the rock has continuous openings that permit flow. (All other ground water recognized in the caldera is perched at higher levels.) South and 
southwest of the caldera rim, mineral-water conduits near the base of the sedimentary section, above the relatively impermeable crystalline rocks, are the downgradient extension of this principal aquifer beneath Cañon de San Diego and the Jemez Plateau. In this form the principal aquifer extends southward as far as Jemez Pueblo. Near there it merges with the regional aquifer in fill deposits of the Rio Grande Rift. No data exist on the regional aquifer farther west, but the aquifer in the east slope of the Nacimiento Mountains west and southwest of the caldera and west of Jemez Pueblo likely merges to the east with the Jemez Plateau-Cañon de San Diego extension of the caldera aquifer. The mixed-water merger zone presumably lies beneath the basins of the Rio Cebolla and Rio Guadalupe to the north and beneath Jemez Pueblo and $Z$ ia Pueblo lands to the south where rocks of the Nacimiento Mountains abut rift-fill deposits in the border fault zone of the rift.

Chemical differences among the known discharge fluids from Valles Caldera indicate outflow at several places in the ring-fracture zone. All sites of discharge appear to be in the western and southwestern parts of the caldera rim. No evidence of escaping geothermal fluid has been found on the northwest or north flanks of the Jemez Mountains. The stableisotope composition of ground water rules out leakage to the east (Fraser Goff, Los Alamos National Laboratory, written commun., November 1993).

Evidence is sparse regarding the general directions of flow within the southern part of the caldera reservoir(s) and the locations of breaches in the ring-fracture zone through which geothermal fluid escapes. As noted in an earlier discussion, Grant and others (1984) suggested that geothermal fluid flows from the Sulphur Springs reservoir toward Redondo Creek and then southward beneath Cañon de San Diego. Goff and others (1988) inferred, on the basis of proximity, that fluid escapes from the Sulphur Springs reservoir by flowing southwestward beneath the Jemez Plateau. The isotopic similarity of the Sulphur Springs geothermal fluid and the water at Soda Dam, noted earlier, supports Grant's interpretation. Chemical and stable-isotope data cited in this report in the discussion of well GT-2, however, may substantiate the inference of flow beneath the Jemez Plateau. Further support is provided by a report of $\mathrm{H}_{2} \mathrm{~S}$ in the plateau region about $2 \mathrm{mi}$ west of the Fenton Hill site (fig. 10) (Bailey, 1961; R.A. Bailey, U.S. Geological Survey, oral commun., 1974), which suggests the presence of boiling fluid in the subsurface. Hence, parts of the flow from the
Sulphur Springs reservoir likely follow both major flow paths-down Cañon de San Diego and beneath the Jemez Plateau (fig. 1).

\section{Cañon de San Diego-San Ysidro Area}

Consideration of the general course of fluid escape from the caldera and its flow down Cañon de San Diego is facilitated by comparing geologic sections in figures 11 and 40 . The schematics show the enormous disparity between the depth of the caldera reservoir(s) and the thickness of the section of sedimentary rocks outside the caldera, in which the derivative mineral water flows away. As earlier noted, Grant and others (1984) placed the nominal potentiometric surface for the Redondo Creek reservoir at an altitude of about $7,875 \mathrm{ft}$, or about $2,000 \mathrm{ft}$ above the level of the basal limestone just outside the ringfracture zone. In the vertical section (fig. 11) artesian flow in the reservoir near the ring-fracture zone moves laterally and upward by convection in a direction perpendicular to the lines of equal temperature. The rising reservoir fluid escapes chiefly through the lowest openings found by the fluid-in the basal limestone. Head loss, which must occur between the reservoir and the ring-fracture zone, is thought to be great enough to permit dilute water in the alluvial aquifer within the moat to infiltrate and mix with the escaping reservoir fluid. The near-surface water table is at an altitude of about 7,610 ft where San Antonio Creek flows out of the caldera and at an altitude of about 7,800 ft near the Fenton Hill site.

Efforts to identify and characterize flow conduits outside the caldera wall have met with only limited success. The conduits seem to have developed preferentially in the basal part of the limestone section regardless of whether their primary geologic control is stratigraphic (as in the Jemez Plateau, well PC-1) or structural (well VC-1 and springs at Soda Dam). Wherever the hydraulic situation at mineral springs is evident (Soda Dam, Jemez Springs, springs D6 and A11; figs. 26 and 41), the springs are seen to be artesian (confined) features. Earlier discussion argues that mineral water, in part derived from the caldera reservoir, flows southward beneath Cañon de San Diego at least as far as Jemez Pueblo, about 20 miles in straight-line distar ze. Flow over such distances, although preserving the chemical character of the fluid, is not unusual in mountainous terrain, according to Ingebritsen and Sorey $(1985$, p. 853-855). Where pathways for lateral flow of liquid water exist, phase 


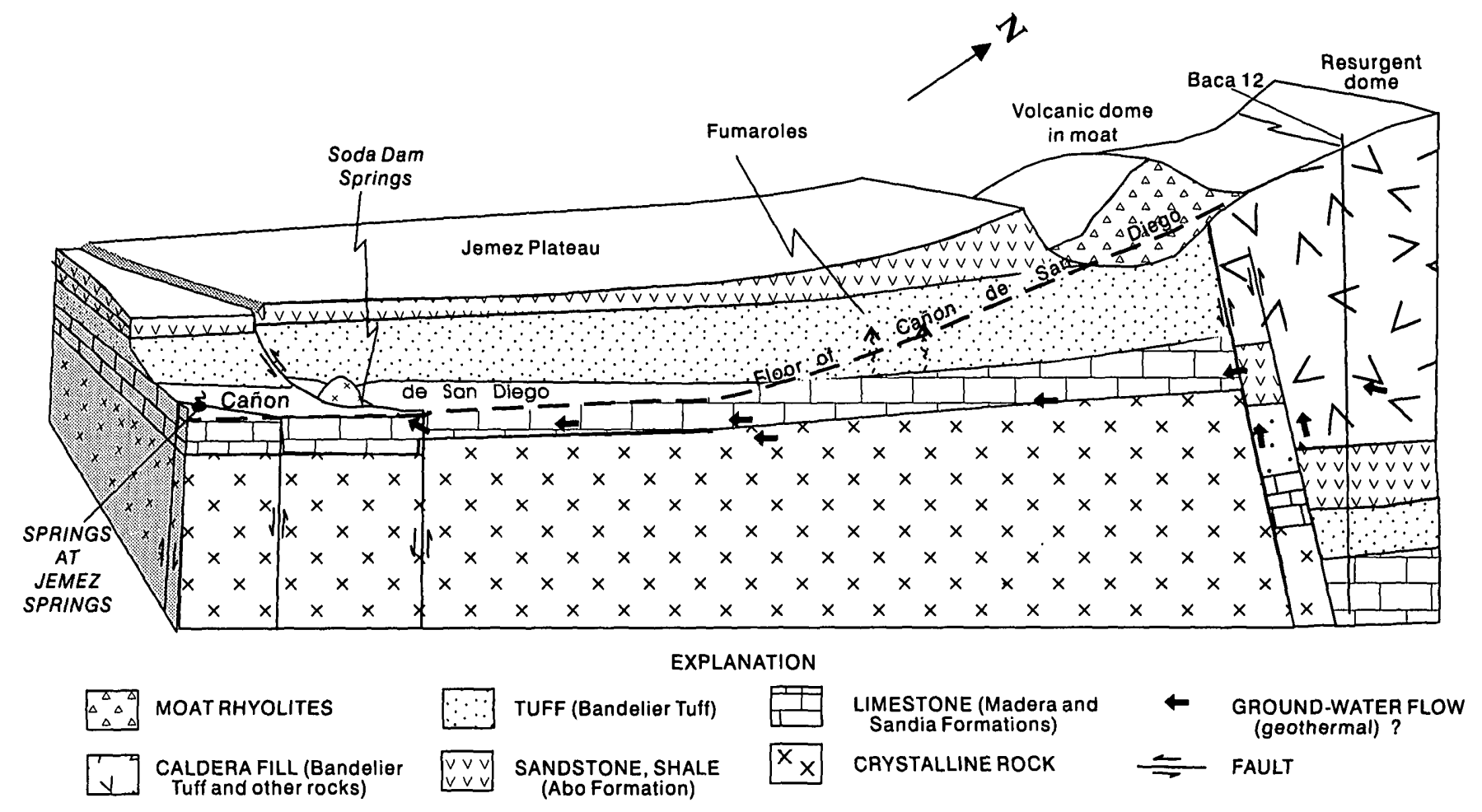

Figure 40.--Flow paths of reservoir fluid escaping from Valles Caldera. The springs at Soda Dam and Jemez Springs drain different conduit systems. Well location shown in figure 5.

separation occurs in a zone of two-phase flow, with liquid water tending to move laterally and steam tending to rise. Sparse evidence suggests the presence of at least two distinct flow systems: one that may be beneath the canyon proper and one that branches off to the west, near Soda Dam, and trends through faulted terrain to the vicinity of Jemez Pueblo. Water in the two systems mixes near San Ysidro with mineral water from the Nacimiento Mountains and with freshwater from rift-fill deposits. From here the mixed water, bearing a considerable load of dissolved salts, flows eastward and southeastward into the principal aquifer in the Albuquerque Basin.

The mineral water from Cañon de San Diego that mixes with other water near San Ysidro is itself a mixed water (or series of mixed water). This interpretation, based on the variation of water chemistry at the springs with time, depends on the confined nature of the conduit systems. An earlier section of this report (fig. 33) ascribed the small $\mathrm{Cl}$ concentrations to (1) increases in ground-water recharge and in the rate of mixing of reservoir fluid and (2) the presence of more dilute local ground water during the annual snowmelt flood event. Also explained was the timing of small $\mathrm{Cl}$ concentrations at the springs (some months distant from the annual flood) in terms of lag time required for mass transport from mixing site to spring. In contrast to $\mathrm{Cl}$ concentration, water discharge and $\mathrm{Cl}$ loads of the springs are largest during the annual snowmelt flood event (fig. 42). These peaks, displaying virtually no lag time, are attributed to the rapid transmission of head change from the site of mixing to the discharge point by pressure waves in confined conduits, with increased spring flow supported by water in the conduit system near the springs. Trainer (1984, p. 252-253) considered three explanations for these pressure waves: (1) changes of head in the geothermal reservoir, (2) repetitive external loading and unloading of conduits by flood water at land surface, and (3) fluctuations in head within conduits transmitted by the dilute water at sites of mixing. 
(A)

NORTH

SOUTH

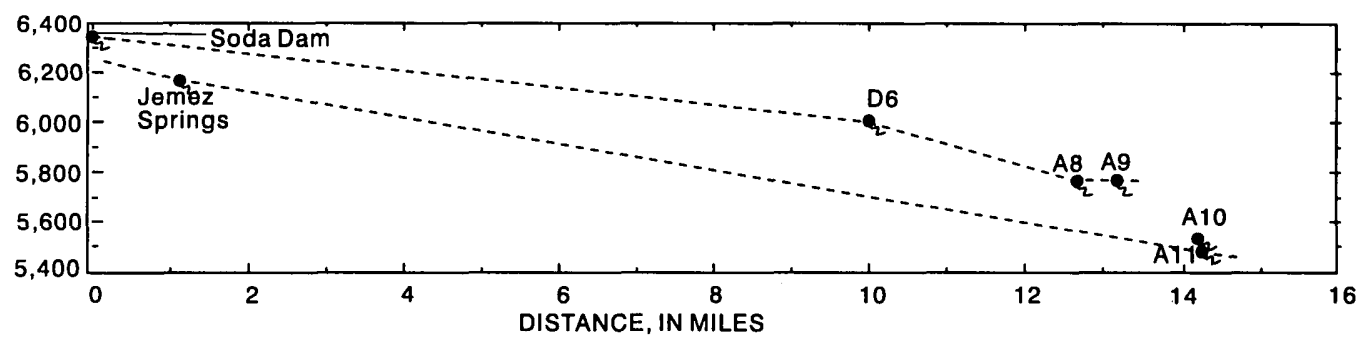

(B)
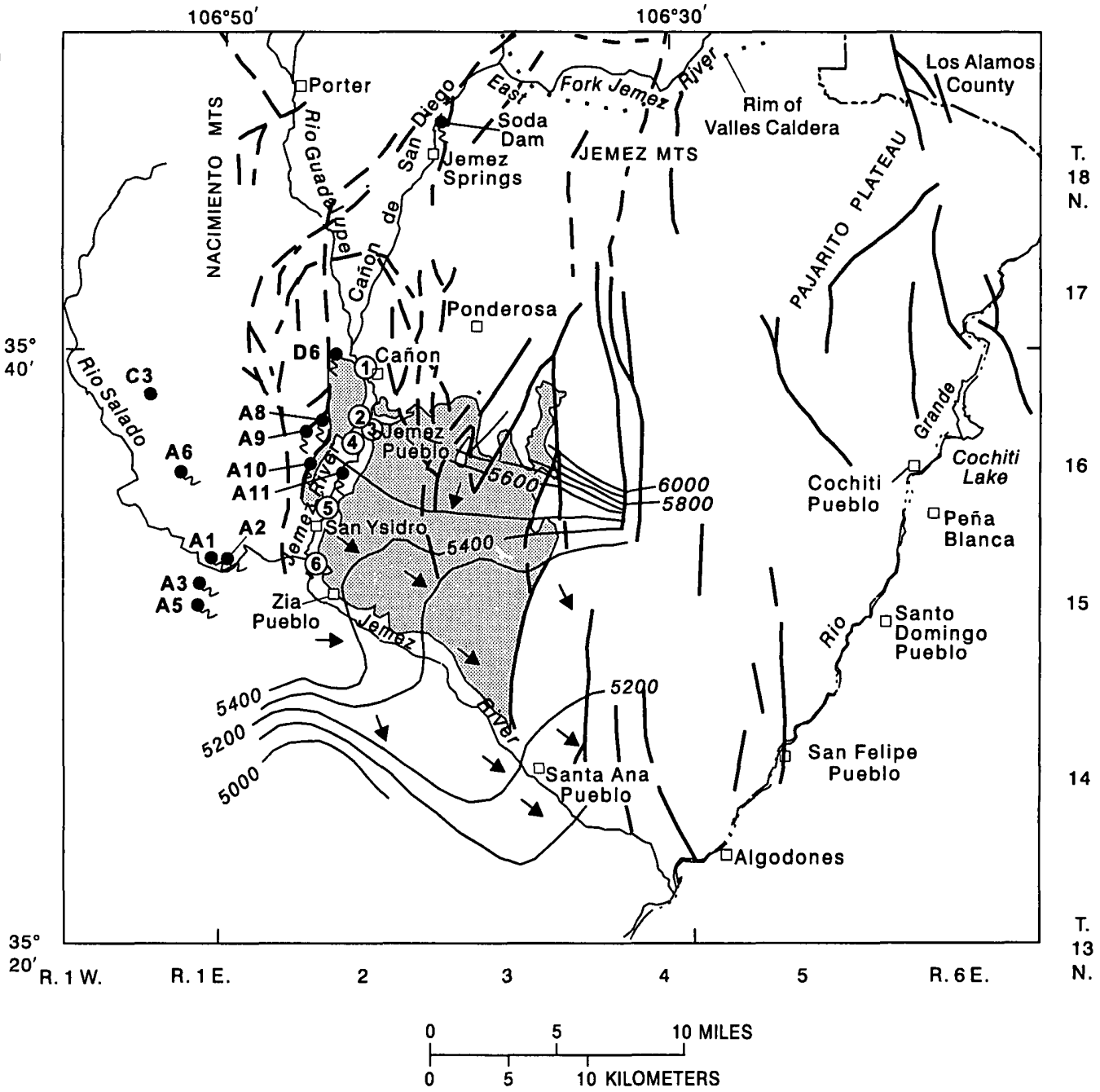

EXPLANATION

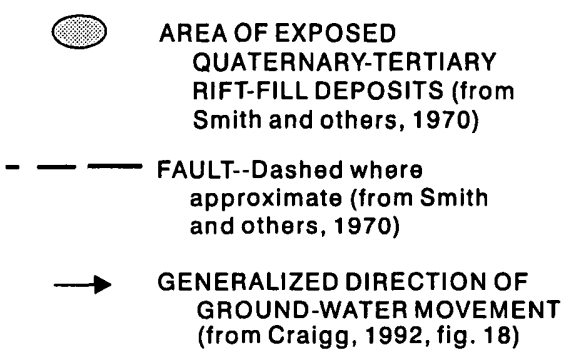

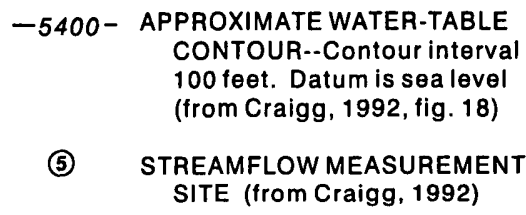

A10 Q 2 SPRING

C3 $\bullet \quad$ WELL

Figure 41.--(A) Inferred profiles of piezometric surfaces in Cañon de San Diego and (B) approximate water-table contours and generalized direction of ground-water movement in rift-fill deposits. 


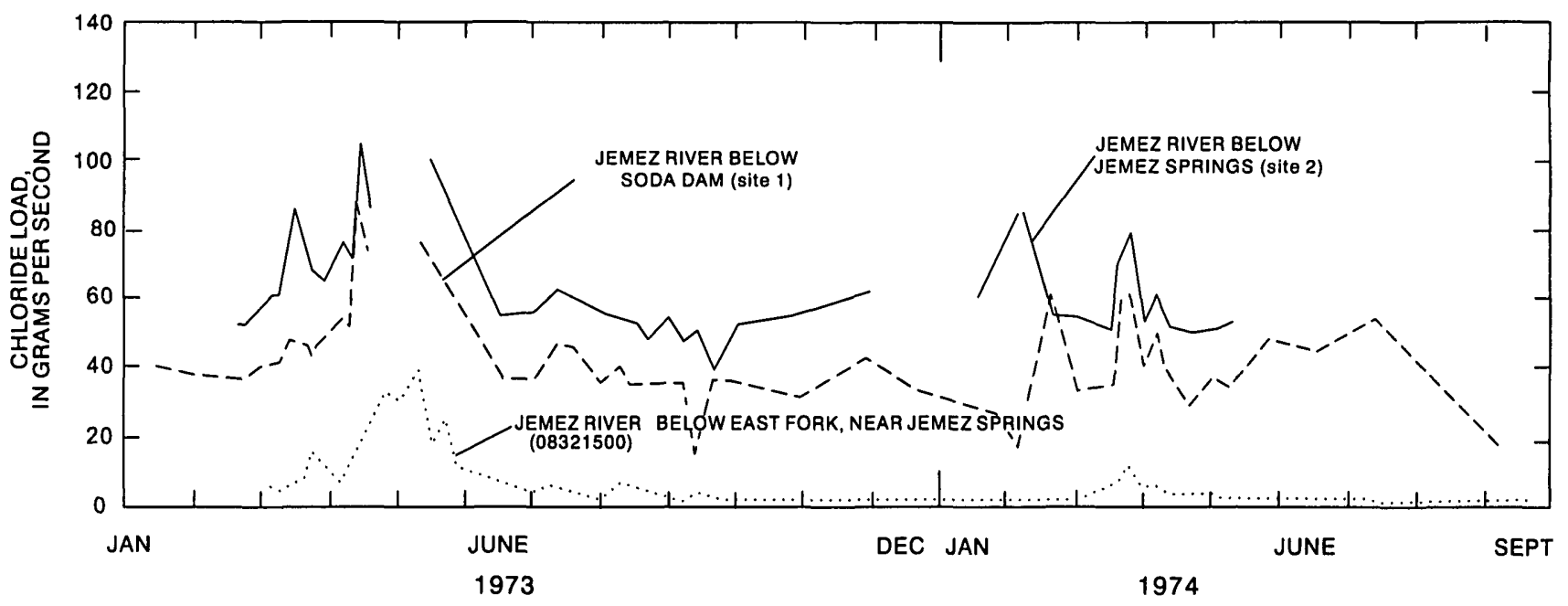

Figure 42.--Chloride load at three sites on the Jemez River, 1973-74 (from Trainer, 1984, fig. 6). Locations shown in figure 6.

The explanation of pressure waves due to head changes in the geothermal reservoir appears untenable because the synchronism shown in the hydrographs would require nearly instantaneous recharging of the geothermal reservoir. Tritium data show that the reservoir fluid is at least 60 years old (Vuataz and Goff, 1986, p. 1851).

Repetitive external loading and unloading of conduits by flood water on land surface nearby can form near-synchronous pressure waves in confined aquifers. However, the magnitude of such loading is unlikely to be more than a few feet of water on the streambed, many hundreds of feet above the subsurface conduit. Additionally, this mechanism provides no explanation for the small concentration of $\mathrm{Cl}$ detected some time afterward at the springs.

In contrast, a pulse of recharge to a flowing body of mineralized water by more dilute ground water from an overlying aquifer during the snowmelt event can provide the short-term head fluctuation and the (delayed) change in ionic concentration that is observed downgradient at the springs. The near coincidence of peaks in streamflow and spring flow is believed to be a transient pressure effect caused by pulses of recharge to confined conduits. Fluctuations in water chemistry described earlier are transport phenomena that lag far behind transient pressure changes.

Study of the caldera-derived mixed water in the region outside the caldera is hindered by a scarcity of data sites, limited to a few wells and springs. The sparseness of data is especially significant in estimating the quantity of reservoir-fluid solutes that escape from the caldera and flow into the major aquifer in the Albuquerque Basin in the Rio Grande Rift.

Earlier discussions describing figure 35 noted a few aberrant values in samples from Soda Dam and Jemez Springs that could imply further dilution. At Soda Dam the pertinent data are for Hidden Spring, in the flood plain a short distance upstream from the dam (table 12). Tritium data for Hidden Spring and for the Jemez River above Soda Dam (table 12) strongly 
suggest dilution of the mineral water by the river, more evidence of local dilution at Jemez Springs. Stableisotope and $\mathrm{Cl}$ data for Hidden Spring and the Jemez River are consistent with local dilution. Concentrations of $\mathrm{Cl}$ in the river during 1982-83 are large because of the dissolved load in streams upstream from Soda Dam. These $\mathrm{Cl}$ concentrations are thought to reflect the escape of ponded effluent stored during production testing of geothermal wells in 1981 and 1982.

At Jemez Springs the location of major springs along fault zones, the consistency of chemical composition of the water, and the levels of dissolvedconstituent concentrations in the spring water indicate that the water probably flows through discrete conduits in the alluvium that overlies the bedrock. Nonetheless, part of the flow up through the alluvium is known to be porous-media flow, and the spatial pattern of water chemistry is complex. Isotopic plots for Jemez Springs samples suggest local dilution (fig. 35). Head in the mineral-water conduits is higher than river level, so mixing must occur through escape of mineral water into the enclosing body of dilute water.
Evidence of mineral water from Valles Caldera is less clear in Cañon de San Diego downstream from Jemez Springs than in the areas already described. Chemical data, however, strongly imply that subsurface mineral water flows as far south as Jemez Pueblo, where it is one of four different types of ground water that merge: (1) Jemez mineral water rises through the alluvium from the underlying bedrock and mixes with (2) ground water in the alluvial deposits and (3) mineral water from the southern Nacimiento Mountains, and all these types of water mix with (4) water in the rift-fill deposits. This water moves southeastward to the major aquifer in the Albuquerque Basin.

The locations of five springs (D6, A8, A9, A10, and A11) in or near the lower Cañon de San Diego that are thought, on the basis of water chemistry, to be fed in part by Valles Caldera geothermal fluid are shown in figure 41B. Chemical analyses of samples from these and several additional sites are listed in table 15 ; majorion composition of the samples is summarized in figure 43.

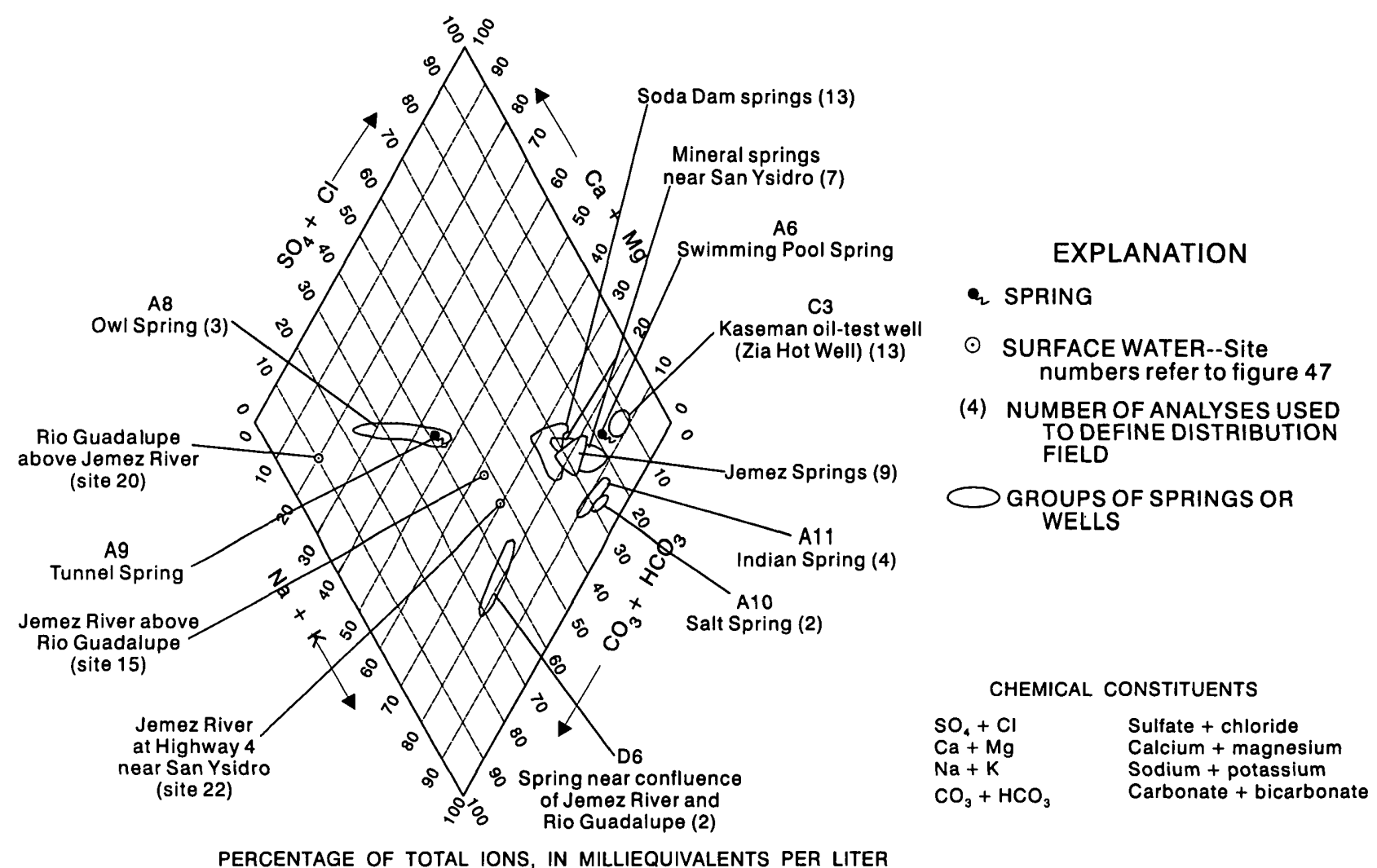

Figure 43.--Ranges in chemical composition of water from wells and springs in the lower Cañon de San Diego, near San Ysidro. Well and spring locations shown in figure 41. 


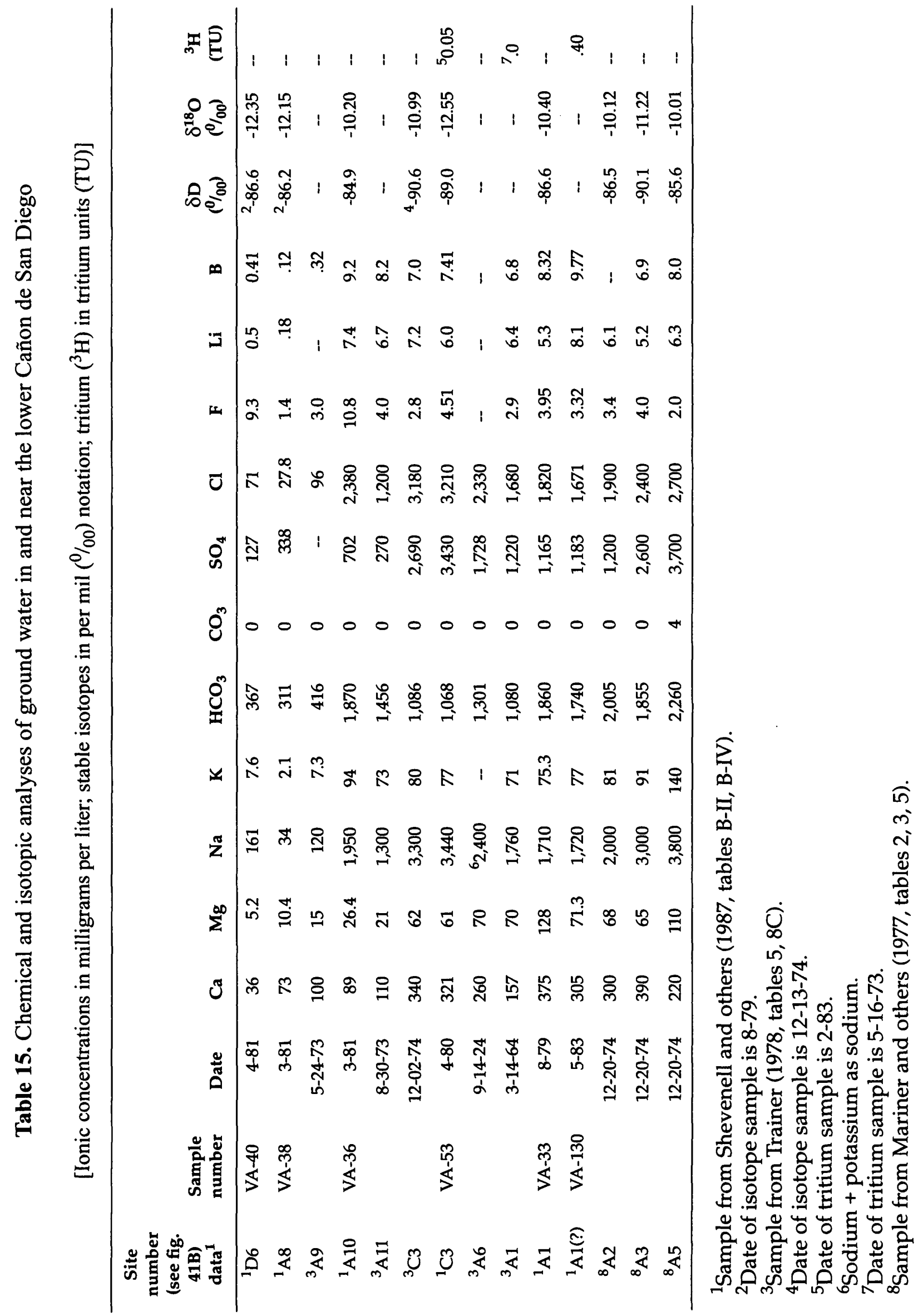


Spring D6 flows from a fault zone within granite located on a hillside, about $320 \mathrm{ft}$ above the level of the Jemez River at the base of the hill. Concentrations of $\mathrm{Cl}, \mathrm{Li}$, and $\mathrm{B}$ in the spring water (table 15) indicate that geothermal fluid is a likely component. At least three hypotheses can be considered for likely flow paths to spring D6: (1) flow through stratigraphically and (to the south) fault-controlled openings beneath the Jemez Plateau and the terrain west of Cañon de San Diego; (2) flow through fault- or bedding-controlled openings at depth beneath Cañon de San Diego; and (3) flow through fault-controlled conduits that leave Cañon de San Diego near Soda Dam (see fig. 5) and trend southward through mountainous terrain west of Cañon de San Diego. The first explanation is unlikely, despite the presence of mixed water beneath the plateau at wells GT-2 and PC-1, because water from spring D6 lacks a limestone signature. Water-level data imply the presence of two confined flow systems in and near lower Cañon de San Diego- one beneath the canyon and one to the west, beyond the ridge that bounds the canyon. Thus, the second and third flow paths hypothesized may be valid. Regardless of path, spring D6 water is a credible mixture of mineral water and dilute ground water like that at Soda Dam or Jemez Springs. Calculations based on $\mathrm{Cl}, \mathrm{Li}$, and $\mathrm{B}$ indicate mixing proportions of approximately 26 (dilute water) to 1 (mineral water) for a parent water similar to that at Soda Dam and 16 to 1 for a parent water similar to that at Jemez Springs.

Owl Spring (A8) and Tunnel Spring (A9) flow from limestone in the hilly terrain west of Cañon de San Diego. Concentrations of $\mathrm{Cl}, \mathrm{Li}$, and $\mathrm{B}$ in both (table 15) imply that the water is a mixture of mineral water and dilute ground water; each has a limestone signature (fig. 43). Both represent the upper of the two inferred flow systems (fig. 41A).

Other spring water and water from well $\mathrm{C} 3$ have a wide range in concentration, though all are mineral water and many are warm. Salt Spring (A10) flows from the Triassic Chinle Formation sandstone west of the river and within Cañon de San Diego. Indian Spring (A11, fig. 41) is located in the bed of the Jemez River on Jemez Pueblo land; the spring water is thought to come from limestone underlying the alluvium. Springs $\mathrm{A} 1, \mathrm{~A} 2, \mathrm{~A} 3$, and A5 (fig. 41B) represent a larger number of small mineral springs, cold or slightly warm, that flow from the Chinle Formation sandstone in the southern part of the Nacimiento Mountains west of San Ysidro. Spring A6 (Swimming Pool Spring) is one of a number of springs that are clustered along the fault zone at the mountain front. Well C3 ("Warm Spring"), an abandoned oil-test well (Clark, 1929; Renick, 1931) at the west base of the Nacimiento Mountains, discharges thermal mineral water (about 50 ${ }^{\circ} \mathrm{C}$ ), at a rate of $80-100 \mathrm{gal} / \mathrm{min}$, from the Madera Limestone. The mineral springs near San Ysidro appear to be fault controlled and well $\mathrm{C} 3$ is located near the fault zone. All the springs and well $\mathrm{C} 3$ in the Nacimiento Mountains have built extensive deposits of travertine.

Trainer (1974) concluded that the composition of mineral water in the lower Cañon de San Diego and near San Ysidro indicates dilution from a single parent geothermal fluid from Valles Caldera. The water and features at the west foot of the Nacimiento Mountains (for example, spring A6 and well C3) appear to be associated with head relations different from those in the lower Cañon de San Diego; thus, substantially different flow paths must be involved if their geothermal parent also is derived from Valles Caldera. More detailed studies (Vuataz and Goff, 1986; Shevenell and others, 1987) have since shown with stable isotopes and water chemistry that the Nacimiento Mountains water and those near San Ysidro are derived not from a Valles Caldera parent but from a separate low-temperature geothermal system along the Nacimiento Fault Zone. The Nacimiento Mountains water has come from or through limestone and gypsum-bearing rocks and, therefore, is characterized by high concentrations of $\mathrm{HCO}_{3}, \mathrm{SO}_{4}$, $\mathrm{Cl}, \mathrm{Li}$, and $\mathrm{B}$. Their most conspicuous differences from mineral water in the upper Cañon de San Diego are larger concentrations of $\mathrm{Cl}$ and particularly of $\mathrm{SO}_{4}$.

Many plots prepared in studies of chemical and isotopic data for springs in the Jemez Mountains (Vuataz and Goff, 1986, fig. 4; Shevenell and others, 1987, figs. 8-14), including several in this report (for example, fig. 43), display extended linear data distributions that may be due to (1) temporal variation in chemical and isotopic character or (2) dilution or mixing of fluids. Mixing of water in the area near San Ysidro is highly probable because the general directions of ground-water flow from surrounding areas are toward San Ysidro-from the San Juan Basin and the Nacimiento Mountains to the west and northwest; from the Jemez Mountains to the north; and from parts of the Rio Grande Rift to the north and northeast (figs. 3 and 41B). 
Figure 44 suggests two mixing systems: (1) The Valles Caldera-Cañon de San Diego system, already discussed in this report. This system includes the caldera fluids, spring water at Soda Dam and Jemez Springs, and water in well VC-1. Water from springs A8, A9, and D6 are thought to be very dilute representatives of this system. (2) The Nacimiento Mountains-San Ysidro system-whose concentrated end member is represented by well C3 and whose other end member is a mixture with Cañon de San Diego water (for example, A10 and A11). The mineral springs near San Ysidro (A1, A2, A3, and A5) represent a series of intermediate mixtures in the Nacimiento Mountains system. The stable-isotope plot in figure 45 confirms the conclusions drawn from the chemistry.

Chemical and discharge data for the Jemez River contribute to further understanding of the mineralwater discharge at Jemez Pueblo. As noted earlier during the discussion of the Jemez River, the stream carries a substantial dissolved load downstream from Soda Dam, largely $\mathrm{Ca}, \mathrm{Mg}$, and $\mathrm{HCO}_{3}$ from limestone and $\mathrm{Na}$ and $\mathrm{Cl}$ from the geothermal reservoir. Part of the water and its dissolved load continues downstream and out of the Jemez Mountains as streamflow; part infiltrates the alluvium beneath the stream and continues its flow as ground water. Water moves from the stream to the ground and from the ground to the stream repeatedly in a complex areal pattern in response to the water-yielding character of the alluvium (specific yield) and local variations in both stream stage and head in the underlying aquifer.

Craigg (1984, table 7; 1992, p. 74-76, figs. 24, 25 , and tables 3,4 ) investigated the relations between shallow ground water and the Jemez River along the 24-mi reach between the USGS streamflow-gaging station Jemez River near Jemez Pueblo (08324000; station 1 in fig. 41B) and Santa Ana Pueblo. Two sets of streamflow measurements were made, both at times of steady streamflow and small or negligible inflow from tributaries. Measurements on March 1, 1984, represent base-flow conditions with little evapotranspiration just before the annual snowmelt flood. Measurements on August 1, 1984, represent latesummer low flow with strong evapotranspiration. Because the August study was complicated by withdrawals for irrigation, only the March data are examined here.

The March data for the river reach between the streamflow-gaging station (1) and the site near San Ysidro (6) (fig. 41B) are summarized in table 16. Except for a losing reach between Vallecito Creek and Jemez Pueblo the river was a gaining stream, and the rate of gain generally increased downstream.
Moreover, the farthest downstream reach (between sites 5 and 6) had the greatest gain in $\mathrm{Cl}$ load. Thus, the reach between sites 1 and 2 showed an increase of about 1 cubic foot per second per mile $\left(\mathrm{ft}^{3} / \mathrm{s} / \mathrm{mi}\right)$ (discharge) and about 1.3 grams per second per mile $(\mathrm{g} / \mathrm{s} / \mathrm{mi})(\mathrm{Cl}$ load). The corresponding rates in reach 4-5 were about $1.8 \mathrm{ft}^{3} / \mathrm{s} / \mathrm{mi}$ and $10.8 \mathrm{~g} / \mathrm{s} / \mathrm{mi}$ and in reach $5-6$ were $1.9 \mathrm{ft}^{3} / \mathrm{s} / \mathrm{mi}$ and $16 \mathrm{~g} / \mathrm{s} / \mathrm{mi}$. Downstream from station 6, the Jemez River was gaining over most of the remainder of the measured reach; however, salts were not studied further because of salt contributed by the Rio Salado (Craigg, 1992). Springs A10 and A11 (table 15 and fig. 41B) are in reach 4-5, and a well near the Jemez River in reach 5-6 (not shown) yielded water similar to that from the springs (Craigg, 1992, p. 17). Inasmuch as uncontaminated (unmixed) ground water in the rift-fill deposits contains much smaller concentrations of $\mathrm{Cl}$ (Craigg, 1992, fig. 8), it is evident from these data that mineralized water is moving upward from the bedrock into the overlying alluvium and into the stream.

The earlier argument that high concentrations of $\mathrm{SO}_{4}$ in ground water in upper Cañon de San Diego are due in part to the oxidation of $\mathrm{H}_{2} \mathrm{~S}$ that rises in flow conduits from boiling fluid at depth would not be tenable near San Ysidro and Jemez Pueblo, where the temperature of mineral water is far below the boiling point. Hence, the origin of $\mathrm{SO}_{4}$ in mineral water of Cañon de San Diego is upcanyon; $\mathrm{SO}_{4}$ in Nacimiento Mountains water is derived largely from gypsiferous rocks in the Nacimiento Mountain front and (or) the San Juan Basin. From this reasoning relations among the different mineral waters (figs. 43-45) possibly can be studied. The concentration of $\mathrm{SO}_{4}$ in water can be expressed in terms of the ratio $\mathrm{Cl} / \mathrm{SO}_{4}$ (both in milligrams per liter). In 16 analyses of water from well $\mathrm{C} 3$ this ratio ranges from 0.78 to 1.18 and the mean is 0.92. In nine samples from spring A6 (Swimming Pool Spring) and the mineral springs near San Ysidro (A1, $\mathrm{A} 2, \mathrm{~A} 3$, and $\mathrm{A} 5$ ) the ratio ranges from 0.73 to 1.6 and the mean is 1.3. In five samples from springs A10 and A11 on Jemez Pueblo land in or near the Jemez River the range is 3.0 to 5.0 and the mean is 4.0 . In 18 samples collected at the Jemez River near Jemez (08324000) gaging station downstream from the confluence of the Jemez River and Rio Guadalupe the range is 0.5 to 17.4 and the mean is 3.8. These mean ratios suggest that fluid from Valles Caldera dominates the mineral water at Jemez Pueblo and that the principal region of mixing of Cañon de San Diego and Nacimiento Mountains water is near and west of San Ysidro. 

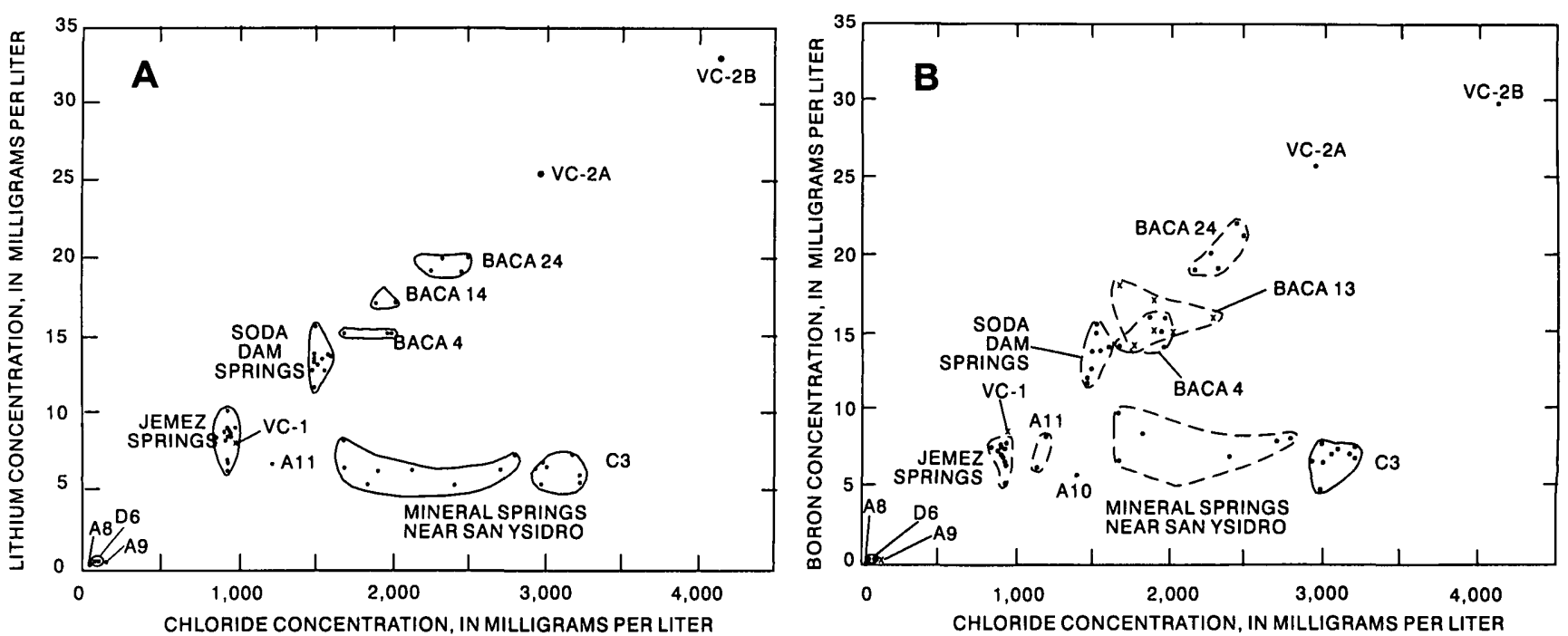

Figure 44.---Covariation of (A) lithium and chloride and $(B)$ boron and chloride in representative reservoir fluids in Valles Caldera and in mixed water in and near Cañon de San Diego (data from Renick, 1931; Mariner and others, 1977, table 2; Trainer, 1978; White, 1986, table 1; Shevenell and others, 1987; and Goff and others, 1992, tables 1 and 2). Well and spring locations shown in figures 5 and $41 \mathrm{~B}$.

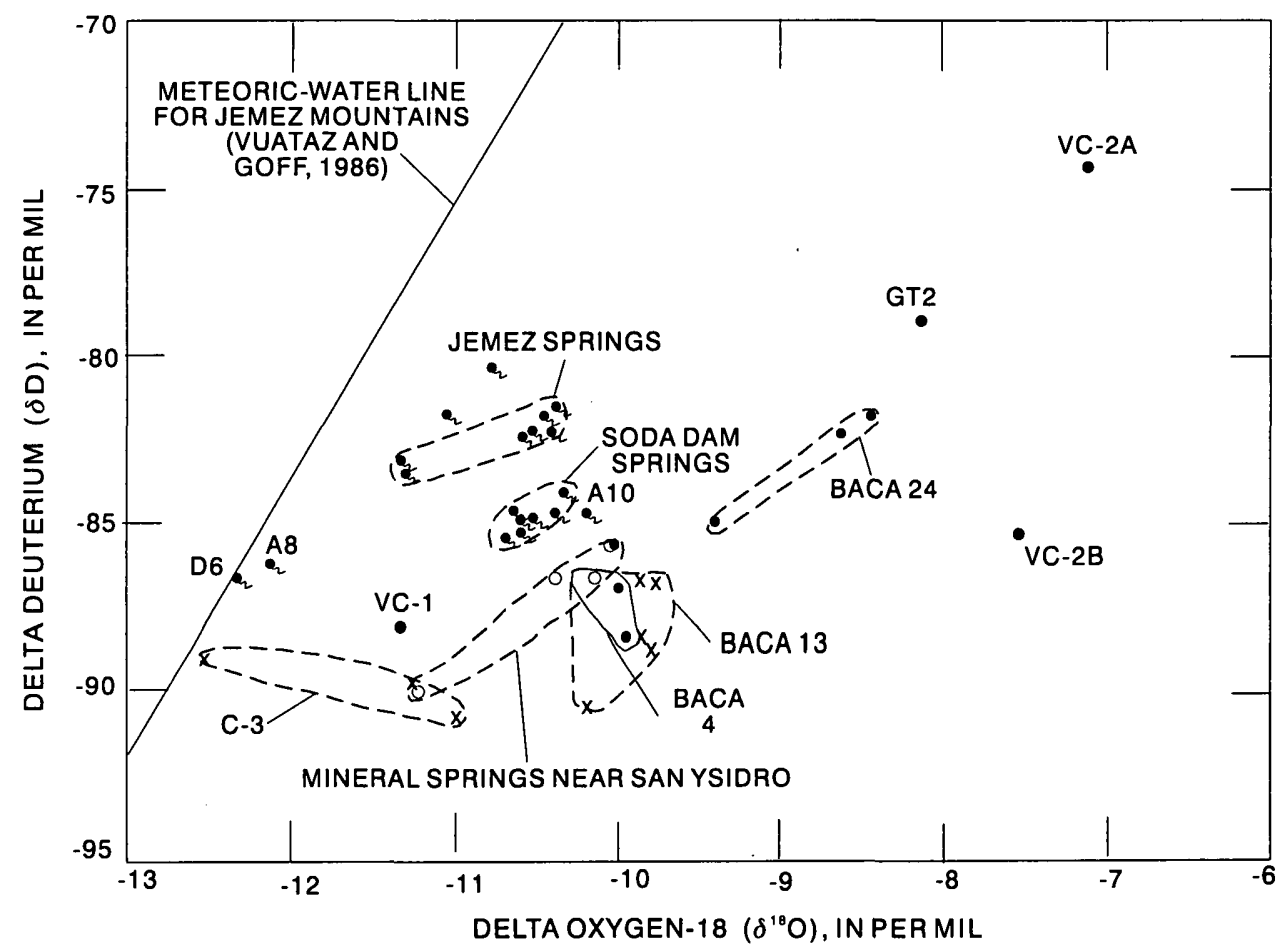

Figure 45.--Covariation of deuterium and oxygen-18 in reservoir fluid in Valles Caldera, derivative water near Cañon de San Diego, and mineral-spring water near San Ysidro and Jemez Pueblo (data from Mariner and others, 1977, table 5; Trainer, 1978; Truesdell and Janik, 1986, table 3; Vuataz and Goff, 1986; Shevenell and others, 1987; and Goff and others, 1992). Well and spring locations shown in figures 5 and $41 B$. 
Table 16. Selected streamflow and chloride data and calculations for reach of Jemez River between U.S. Geological Survey streamflow-gaging station Jemez River near Jemez (08324000) and San Ysidro, March 1, 1984

[Data from Craigg (1992, table 3); $\mathrm{ft}^{3} / \mathrm{s}$, cubic feet per second; $\mathrm{mg} / \mathrm{L}$, milligrams per liter; g/s, grams per second; NA, not applicable; --, no data]

\begin{tabular}{cccccc}
\hline $\begin{array}{c}\text { Measurement } \\
\text { site } \\
\text { (fig. 41B) }\end{array}$ & $\begin{array}{c}\text { Distance } \\
\text { downstream } \\
\text { (miles) }\end{array}$ & $\begin{array}{c}\text { Discharge } \\
\left(\mathbf{f t}^{3} / \mathbf{s}\right)\end{array}$ & $\begin{array}{c}\text { Gain }(+) \text { or } \\
\text { loss }(-)\left(\mathbf{f t}^{3} / \mathbf{s}\right)\end{array}$ & $\begin{array}{c}\text { Chloride } \\
\text { concentration } \\
(\mathbf{m g} / \mathbf{L})\end{array}$ & $\begin{array}{c}\text { Chloride } \\
\text { load (g/s) }\end{array}$ \\
\hline${ }^{1} 1$ & NA & 37.8 & NA & 47 & 50.3 \\
2 & 3.6 & 41.3 & +3.5 & 49 & 55.0 \\
23 & -- & 1.5 & -- & 21 & .89 \\
4 & 4.2 & 37.2 & -5.6 & 48 & 50.6 \\
5 & 8.1 & 44.2 & +7.0 & 74 & 92.6 \\
36 & 11.2 & 50.2 & +6.0 & 100 & 142.2 \\
\hline
\end{tabular}

${ }^{1}$ Jemez River near Jemez.

${ }^{2}$ Vallecito Creek (tributary) at mouth.

${ }^{3}$ Report of quicksand suggests the presence of springs in the riverbed.

\section{Discharge from the Geothermal Reservoir}

The concealment of discharge conduits and much of the discharge presents a major difficulty in estimating geothermal discharge. A somewhat mitigating circumstance is that the geothermal reservoir(s) seems to discharge only along the southwestern rim of the caldera. The known area of discharge is bounded laterally by well GT- 2 on the west and well VC-1 on the east (fig. 5). The areal distribution of shallow-temperature gradients in this region of the Jemez Mountains (Sass and Morgan, 1988, fig. 9), which reflects the areal pattern of conductive heat flow toward the surface, suggests that the area of outflow may extend as much as 2 mi east of well VC-1. Thermal data, combined with other information on surficial and subsurface geology and hydrochemistry, provide a convincing model of the region of thermal-fluid outflow (Goff and others, 1988, fig. 3; 1992, fig. 6).

Lateral discharge from the geothermal reservoir(s) consists of three components - heat, reservoir fluid, and dissolved load. Several estimates have been made of the magnitude of reservoir fluid discharge. These estimates, based on water chemistry, are diverse and difficult to compare with one another; all imply a rather small reservoir fluid discharge.

Water Resources Associates, Inc. (1977) estimated the total average discharge from the reservoir(s) of $164 \mathrm{gal} / \mathrm{min}$ from springs and other sources not identified and $152 \mathrm{gal} / \mathrm{min}$ in base flow at the Jemez River near Jemez (08324000) gaging station, upstream from Jemez Pueblo. In light of present understanding, the spring-flow element is considered to be overestimated because dilute water having no reservoir component is included. The base-flow element is overestimated if it includes spring flow already counted, and the total is underestimated because the ion-mixing calculation is based on As, a nonconservative element in ground-water and stream environments. Finally, possible conduit flow is not accounted for from Valles Caldera in the reach of canyon south of Jemez Pueblo.

Balleau (1980) estimated fluid discharge from the Valles Caldera reservoir through ion-mixing calculations, using concentrations of eight constituents $(\mathrm{Cl}, \mathrm{F}, \mathrm{Br}, \mathrm{Na}, \mathrm{K}, \mathrm{Li}, \mathrm{As}$, and $\mathrm{Br}$ ) and data from the principal sources available at the time (Purtymun and 
others, 1974; Water Resources Associates, Inc., 1977, app. 2; Trainer, 1978; and U.S. Department of Energy, 1980 , tables 3.8 and 3.9). Mixing calculations using winter (January 29, 1974) measurements of streamflow resulted in an estimate of $450 \mathrm{gal} / \mathrm{min}$ (about $1 \mathrm{ft}^{3} / \mathrm{s}$ ) for the flow of caldera-derived geothermal fluid carried by the Jemez River at Highway 4 between Jemez Pueblo and San Ysidro. This is a reasonable estimate and constitutes the larger part of geothermal discharge down Cañon de San Diego to this point. However, several uncertainties affect estimation of total geothermal fluid discharge at this site.

Total geothermal fluid discharge consists of three components: ground-water underflow in alluvium beneath the stream channel and canyon floor; conduit flow in bedrock, which continues downcanyon; and streamflow. Underflow is estimated here to supplement the $1-\mathrm{ft}^{3} / \mathrm{s}$ streamflow value estimated by Balleau (1980). As noted earlier, streamflow and $\mathrm{Cl}$ data reported by Craigg (1992) support a larger estimate of the mineral-water component at a gaging station farther downstream (Jemez River above Rio Salado). That estimate is not discussed here because of uncertainty about whether the dissolved load has been brought entirely from Cañon de San Diego or (as is likely) partly from Nacimiento Mountains sources.

\section{Ground-Water Under?}

At Jemez Pueblo, the canyon has been incised into rift-fill deposits of Zia Sand, a sequence of siltstone and partly consolidared fine-grained sandstone that is about $1,000 \mathrm{ft}$ thick at its type section in the hills, 8. mi south-southwest of San Ysidro. The Zia Sand locally stands above the floor of lower Cañon de San Diego as erosional terraces and west of Jemez Pueblo as small buttes. At Jemez Pueblo, the thickness of Quaternary alluvium penetrated by wells in the canyon floor is $100 \mathrm{ft}$ or more, and a well beside the river in San Ysidro is reported to have penetrated $7 \mathrm{ft}$ of alluvium (Craigg, 1984, table 1). The driller's log for the 81-ft well at Jemez Pueblo lists "solid sand" at 77 to $81 \mathrm{ft}$, which may be Zia Sand; alluvium is reported to be at least $55 \mathrm{ft}$ thick at a bridge site near Jemez Springs and also at Jemez Canyon Dam (fig. 1) north of Bernalillo (Spiegel, 1962, p. 1, 10). Four wells near Battleship Rock, beside the Jemez River at the rim of the caldera, penetrate minimum thicknesses of 39 to 80 $\mathrm{ft}$ of alluvium. The $\log$ of the geothermal test well at Jemez Springs reports $80 \mathrm{ft}$ of alluvium overlying bedrock in the canyon floor (Goff and others, 1981).
Thus, the Jemez River alluvium appears to be about 80 ft thick (and locally may be thicker, perhaps as a result of deposition accompanying deformation in areas of faulting). The $80-\mathrm{ft}$ value is comparable to $75 \mathrm{ft}$ of incision and subsequent backfilling that occurred along the Rio Grande at Albuquerque in late-glacial and postglacial time (Kelley, 1969, p. 13).

The estimated underflow ranges from 7 to 14 $\mathrm{ft}^{3} / \mathrm{s}$ and was determined on the basis of the following assumptions: thickness of permeable section, about $100 \mathrm{ft}$ (the underlying Zia Sand, much less permeable than the alluvium, is ignored in this calculation); width of section, about 3,200 to $6,400 \mathrm{ft}$; downcanyon watertable gradient (gradient of river), $15 \mathrm{ft}$ per mile ( $\mathrm{ft} / \mathrm{mi}$ ); and hydraulic conductivity, about $8.7 \times 10^{-3}$ feet per second (ft/s) (about 750 feet per day ( $\mathrm{ft} / \mathrm{d}$ )). By using an intermediate value of underflow of $10 \mathrm{ft}^{3} / \mathrm{s}$ and $\mathrm{Cl}$ concentrations of $100 \mathrm{mg} / \mathrm{L}$ for underflow and 2,500 $\mathrm{mg} / \mathrm{L}$ for the original reservoir fluid, the balance equation used in an earlier discussion (eq. 5, p. 72) yields an estimate of 4 percent of the $10-\mathrm{ft}^{3} / \mathrm{s}$ underflow or $0.4 \mathrm{ft}^{3} / \mathrm{s}$ being composed of geothermal fluid from the caldera. The total estimated flow of geothermal fluid past the site, $1 \mathrm{ft}^{3} / \mathrm{s}$ in streamflow and $0.4 \mathrm{ft}^{3} / \mathrm{s}$ in underflow, or $1.4 \mathrm{ft}^{3} / \mathrm{s}(628 \mathrm{gal} / \mathrm{min})$, is a reasonable estimate for the hydrologic conditions of winter 1974. It is an underestimate by the unknown magnitude of any conduit flow that continues past (beneath) the site and an overestimate to the extent that the area of mixing of fluids from Valles Caldera and Nacimiento Mountains extends upstream into Cañon de San Diego. To some degree these opposing "errors" should cancel one another.

\section{Conduî Flow in Bedrock}

The pattern and number of known and inferred faults in the area north and east of San Ysidro (fig. 1) suggest the possibility of additional subsurface flow paths from the caldera to the Albuquerque Basin through conduits in bedrock. Flow along such routes might be verified and the locations of flow paths determined within broad limits if increases in geothermal-indicator constituent concentrations were found in the Jemez River between San Ysidro and the Rio Grande, or in the Rio Grande itself.

Anderholm (1988, p. 89) reported several wells in Bernalillo, most of them east of the Rio Grande, in which the water contains $\mathrm{Cl}$ and $\mathrm{SiO}_{2}$ in concentrations that in this region are suggestive of geothermal water. He pointed out that these wells are situated on the 
projected southward continuation of faults exposed in Santa Ana Mesa north and west of the Rio Grande and suggested two alternative explanations for the anomalous water quality: (1) faults in Santa Ana Mesa, which continue southward through bedrock and semiconsolidated rift-fill sediments, may be conduits for geothermal fluid from Valles Caldera or (2) the mineralized water came from Jemez River, infiltrated the streambed, and flowed southward in the valley-fill aquifer. The fault-conduit explanation is the more probable because ground water at shallow depths, flowing toward the Rio Grande from the north and west, would more likely become part of the underflow moving parallel to the river than to pass transversely beneath it. The alluvium beneath the river must fill a slot incised in the rift fill, as it does in Albuquerque, and the greater permeability of the alluvium would facilitate the normal underflow downstream. Water in fault conduits, however, could cross beneath the river at depths greater than the ribbon of alluvium, particularly if it were under greater head than the shallow ground water near the river.

Dissolved-constituent load from Valles Caldera entering the regional aquifer of the Albuquerque Basin as conduit flow is less readily dispersed and may form bodies of mineralized water within the basin aquifer.

Such a process is thought to underlie the observations reported by Anderholm (1988). Although discussion of caldera-derived constituents in earlier sections of this report emphasized conservative species such as $\mathrm{Li}$ and $B$, which are effective tracers, other constituents such as As are of greater interest in issues related to domestic and public-water supply.

Recent investigations in the town of Bernalillo imply the extent of arsenic in local ground water. Kelly and Reinert (1996, p. 481) reported that numerous mixed samples of water from the two municipal wells east of the Rio Grande had concentrations of As larger than 50 micrograms per liter $(\mu \mathrm{g} / \mathrm{L})$ (the maximum concentration limit established by the U.S.

Environmental Protection Agency, 1977). Such concentrations explain the finding of As concentrations approaching $50 \mu \mathrm{g} / \mathrm{L}$ in Bernalillo Wastewater Treatment Plant discharge (Pierce, 1989, p. 35; New Mexico Environment Department, 1991, p. 126, 129, 132). The wastewater, which was pumped from the town wells before municipal use, contained $47 \mu \mathrm{g} / \mathrm{L} \mathrm{As}$ on July 25, 1988. A suite of samples collected in JuneSeptember 1991 contained 31 to $43 \mu \mathrm{g} / \mathrm{L}$ As; during the same period the concentration of As measured in discharge from Jemez Canyon Dam ranged from 12 to
$21 \mu \mathrm{g} / \mathrm{L}$. This difference favors the hypothesis that the body of mineralized water Anderholm (1988) reported in Bernalillo was derived from conduit flow.

Little is known of ground-water quality between San Ysidro and the Rio Grande. A few records identify wells beside and south of Jemez River in which large concentrations of $\mathrm{Cl}$ (as much as several hundred milligrams per liter) have been reported (Craigg, 1984, tables 1, 3; Anderholm, 1988, table 10) and that probably reflect infiltration from the Jemez River. Kelly and Reinert (1996, tables 1 and 2) presented ground-water data for this reach of the Jemez River and in Bernalillo west of the Rio Grande that show As concentrations to be zoned or banded stratigraphically. The smaller concentrations were detected in layers shown by geophysical logs to have greater wateryielding potential than other layers, an observation that implies greater dilution in the layers that have higher transmissivity (Kelly and Reinert, 1996, p. 482).

\section{Streamflow}

A series of streamflow measurements was made by the USGS, February 14-15, 1974, in the reach from Otowi Bridge, just south of San Ildefonso Pueblo, to Bernalillo (fig. 1); selected constituent loads were determined using concentrations of $\mathrm{Cl}, \mathrm{Li}$, and $\mathrm{B}$. The study sought to determine (1) the existence of any inflow of geothermal fluid from the Pajarito Plateau along the east side of the Jemez Mountains (between Otowi Bridge and San Felipe) and (2) the presence of any inflow downstream from San Felipe (where faults appear to be more numerous than in the Pajarito Plateau) that cannot be explained by the chemical load carried to the Rio Grande by the Jemez River. The data and calculated loads of $\mathrm{Cl}, \mathrm{Li}$, and $\mathrm{B}$ are summarized in table 17.

The measurements were made during a period of stable streamflow (table 18). The relation of discharge at San Felipe to that at Otowi Bridge is complicated by the flow control exerted behind Cochiti Dam between the two sites. Nonetheless, given the increase in discharge from Cochiti Dam on February 13-14, the data in table 18 do not reveal an increase in $\mathrm{Cl}, \mathrm{Li}$, or $\mathrm{B}$. The subsequent study by Goff and Sayer (1980), which used stable isotopes, showed conclusively that there is no measurable leakage of geothermal fluid from Valles Caldera into the rift-fill deposits beneath the Pajarito Plateau. 
Table 17. Chemical loads for selected ions in the Rio Grande, Otowi Bridge to Bernalillo [Data from Trainer (U.S. Geological Survey, 1975, 1976, and 1978, table 6). $\mathrm{ft}^{3} / \mathrm{s}$, cubic feet per second; L/s, liters per second; g/s, grams per second; --, no data]

\begin{tabular}{|c|c|c|c|c|c|c|c|c|c|}
\hline \multirow{2}{*}{$\begin{array}{l}\text { Streamflow- } \\
\text { gaging station }\end{array}$} & \multirow[b]{2}{*}{ Date } & \multicolumn{2}{|c|}{ Discharge } & \multicolumn{3}{|c|}{ Concentration $(\mathrm{mg} / \mathrm{L})$} & \multicolumn{3}{|c|}{ Load $(g / s)$} \\
\hline & & $\mathrm{ft}^{3} / \mathrm{s}$ & $\mathrm{L} / \mathrm{s}$ & $\mathrm{Cl}$ & $\mathbf{L i}$ & B & $\mathrm{CI}$ & $\mathbf{L i}$ & $\overline{\mathbf{B}}$ \\
\hline $\begin{array}{l}\text { Rio Grande at } \\
\text { Otowi Bridge }\end{array}$ & $2-14-74$ & ${ }^{1} 726$ & 20,560 & 9 & 0.02 & 0.05 & 185 & 0.41 & 1.03 \\
\hline $\begin{array}{l}\text { Rio Grande at } \\
\text { San Felipe }\end{array}$ & $2-14-74$ & ${ }^{1} 882$ & 24,978 & 8 & .20 & .05 & 200 & .50 & 1.25 \\
\hline $\begin{array}{l}\text { Jemez River } \\
\text { below Jemez } \\
\text { Canyon Dam }\end{array}$ & $2-15-74$ & 249 & 1,388 & 314 & - & -- & 436 & -- & -- \\
\hline $\begin{array}{l}\text { Rio Grande at } \\
\text { Bernalillo }\end{array}$ & $2-14-74$ & ${ }^{1} 701$ & 19,852 & 24 & .11 & .14 & 476 & 2.18 & 2.78 \\
\hline
\end{tabular}

${ }^{1}$ Measured discharge.

${ }^{2}$ Mean daily discharge from gage-height record.

Table 18. Mean daily discharge at selected streamflow-gaging stations, February 11-15, 1974

[Data from U.S. Geological Survey, 1975; all values in cubic feet per second]

\begin{tabular}{lccccc}
\hline & \multicolumn{5}{c}{ Discharge } \\
\cline { 2 - 6 } \multicolumn{1}{c}{ Streamflow-gaging station } & $\mathbf{1 1}$ & $\mathbf{1 2}$ & $\mathbf{1 3}$ & $\mathbf{1 4}$ & $\mathbf{1 5}$ \\
\hline Rio Grande at Otowi Bridge & 662 & 667 & 684 & 706 & 694 \\
Rio Grande below Cochiti Dam & 650 & 656 & 571 & 714 & 695 \\
Rio Grande at San Felipe & 673 & 683 & 582 & 789 & 715 \\
Jemez River below Jemez Canyon Dam & 76 & 41 & 43 & 70 & 49 \\
\hline
\end{tabular}


Dam control also affects the quality of data for the river reach between San Felipe and Bernalillo. Jemez Canyon Reservoir (fig. 1) is operated for desilting and flood control; during the 5-day period shown in table 18, releases from the reservoir fluctuated more widely than did flow in the main stem. In this study all measurements and sampling on the main stem of the Rio Grande were completed in a single day, but time was not sufficient to visit Jemez Canyon Reservoir. Because routine sampling at the gaging station below the reservoir was scheduled for the next day, the routine sample and the discharge calculated from the recorder gage height were used. The $\mathrm{Cl}$ load entries in table 17 are reasonably interpreted to indicate a substantial inflow of $\mathrm{Cl}$ to the Rio Grande between San Felipe and the mouth of the Jemez River. But a calculation using the mean discharge at the gaging station Jemez River below Jemez Canyon Dam for February $14\left(70 \mathrm{ft}^{3} / \mathrm{s}\right.$; table 18) yields a load of 622 grams per second (g/s) Cl. Clearly, these results are inconclusive: there may be geothermal inflow to the Rio Grande, but the increase in $\mathrm{Cl}$ load observed in the reach from Otowi Bridge to Bernalillo can be attributed to $\mathrm{Cl}$ load from the Jemez River. Determining possible additional subsurface discharge from Valles Caldera to the Jemez River east of San Ysidro or directly to the Rio Grande will require repeating the constituent-load study on the Rio Grande downstream from Cochiti Dam and conducting a similar study on the Jemez River between San Ysidro and the Rio Grande.

The magnitude of geothermal-fluid discharge from Valles Caldera has been considered at least twice since completion of field work by the USGS in 1975 . First, because the surface water of the Jemez River system is already fully appropriated, any consumptive use of water in the development of geothermal power in Valles Caldera would require approval by the Office of the State Engineer to modify an existing right to permit an alternate point of diversion, a new destination, and a new purpose of water. Among the findings of a hearing into this matter (New Mexico State Engineer, 1980) were two conclusions about the geothermal discharge. (1) Discharge from the geothermal aquifer (reservoir), as measured by increases in selected constituent concentrations in the Rio Grande at its confluence with the Jemez River, ranges from 1,500 to 2,630 acre-ft/yr (approximately 2.0 to $3.6 \mathrm{ft}^{3} / \mathrm{s}$ ), with an average value of $2,030 \mathrm{acre}-\mathrm{ft} / \mathrm{yr}\left(2.8 \mathrm{ft}^{3} / \mathrm{s}\right)$. Of this discharge, 523 to 730 acre- $\mathrm{ft} / \mathrm{yr}$ (approximately 0.7 to $1.0 \mathrm{ft}^{3} / \mathrm{s}$ ), with an average of $632 \mathrm{acre}-\mathrm{ft} / \mathrm{yr}\left(0.86 \mathrm{ft}^{3} / \mathrm{s}\right)$, reaches the Jemez River between the East Fork Jemez River and San Ysidro. This conclusion was based on a presentation by W.P. Balleau for the protestant Bureau of Indian Affairs. Whether the data were adjusted to account for constituents contributed by drainage from the Nacimiento Mountains is not clear. (2) There is no contribution from the geothermal aquifer to the Rio Grande upstream from the confluence of the Rio Grande and the Jemez River.

Moreover, Faust and others (1984, p. 605), in the design of a numerical model of the geothermal system in Valles Caldera, used earlier conclusions by Balleau (1980) that (1) the total thermal-fluid contribution to the Jemez River upstream from San Ysidro is 724 acre$\mathrm{ft} / \mathrm{yr}$ (about $1 \mathrm{ft}^{3} / \mathrm{s}$ ) and (2) the constituent balance implies an annual accretion to the Rio Grande between Otowi Bridge and Bernalillo (including the Jemez River) of 2,580 acre- $\mathrm{ft}$ (about $3.5 \mathrm{ft}^{3} / \mathrm{s}$ ) of fluid having an original concentration equal to that of Jemez Mountains geothermal water. Faust and others (1984, p. 605) recognized that contributions from Nacimiento Mountains sources change the constituent balance in the Jemez River downstream from San Ysidro.

\section{Perched Ground Water in Bedrock}

Perched ground water has been identified by drilling; other areas of perched ground water, however, particularly the larger zones, are known from springflow and chemical data. Doubtless many perched zones of limited thickness and area are as yet undiscovered.

Two principal types of perched ground-water reservoirs in bedrock were noted in an earlier discussion: (1) those within volcanic rocks that overlie relatively impermeable rock and (2) those within sedimentary rocks that are underlain by less permeable beds in the same formation. Reservoirs of the first type are a typical product of the particular volcanic history of this region. The Abo Formation-sandstone, shale, and siltstone-was exposed at the surface over much of the landscape on which the Bandelier Tuff, a younger volcanic unit, was deposited. Although the prevolcanic land surface must have been modified by avalanches and other catastrophic effects of the eruptions, the major land-surface features doubtless were preserved beneath the tuff except perhaps near the crater. Crosssectioned remnants of the ancient landscape can now be seen as the Abo-Bandelier unconformity exposed locally in the walls of Cañon de San Diego. Except for 
their general slope away from the volcano, few additional details are known of the buried landscape, although several observations suggest their gross form.

First, without exception the perched water is old. In three warm-water springs within the ring-fracture zone (P-9, H-39, and H-42; fig. 7), tritium concentrations in eight samples (Trainer, 1978; Vuataz and Goff, 1986) ranged from 0.2 to $5.1 \mathrm{TU}$ and averaged 1.0 TU; five values were less than $0.4 \mathrm{TU}$.

Second, in these three warm-water springs, constituent concentrations are small but have a tendency toward cyclical fluctuation reminiscent of that described in an earlier section on mineral water at Soda Dam and Jemez Springs. This probably means that each spring system is recharged at a small number of discrete places rather than over the general drainage area. Consistent with this observation, the tritium values for each spring mostly consist of a large value and two smaller values, rather than similar concentrations; for example, at Spence Spring (H-42) near Battleship Rock the three values are 0.2, 0.2, and 1.9 TU.

Third, in terms of stable isotopes the water falls on the meteoric-water line (Vuataz and Goff, 1986). This means that recharge is from land surface and that no component of geothermal water is of deep origin.

These observations support a conceptual model of a long and narrow reservoir - not a single body of that shape but rather an interconnected series of segments - consistent with the former drainage net on the Abo Formation surface. Recharge from the present land surface on the volcanic rocks occurs at only a few places in each system, probably through fractures or along boundaries between flows. For the three warmwater spring systems, the present topographic relief is large; the thickness of volcanic rocks in the flow system and the depth of circulation may be many hundreds of feet. The areas involved are not known but are probably large enough for total relief on the Abo Formation basement in each system to reach several hundred feet. In these systems ground water is warm because of high conductive heat flow from the underlying host rocks.

Several spring systems in the Bandelier Tuff located farther down Cañon de San Diego display the major characteristics just described. The springs are situated at low points on the unconformity between the tuff and the Abo Formation. Recharge is thought to be by infiltration through fractures from the mesa surfaces.
Finally, observations during the drilling of well GT-2 led to the drilling of a shallow water-supply well at the Fenton Hill site (fig. 10). The well yielded water from two volcanic-rock units, the Abiquiu Tuff and the Paliza Canyon Formation, which overlie the Abo Formation and underlie the Bandelier Tuff.

Observation wells were drilled nearby for use in aquifer tests.

Two series of aquifer evaluations were made, one by American Ground Water Consultants, Inc. (1980a, b), the other by Los Alamos Scientific Laboratory (Becker and others, 1981). American Ground Water Consultants, Inc. estimated that induced infiltration is likely to result from pumpage from the shallow supply well. Transmissivity was determined to be 7,000 gallons per day per foot (gal/d/ft) $\left(935 \mathrm{ft}^{2} / \mathrm{d}\right)$, later revised to $1,740 \mathrm{gal} / \mathrm{d} / \mathrm{ft}\left(230 \mathrm{ft}^{2} / \mathrm{d}\right)$. The storage coefficient was assumed to be $1 \times 10^{-5}$. By assuming a rate of withdrawal of 10 acre- $\mathrm{ft} / \mathrm{yr}$ for 10 years, American Ground Water Consultants, Inc. (1980a, b) estimated that stream depletion (induced infiltration) in the Rio Cebolla (in the Rio Guadalupe Basin) after 1, 5,10 , and 20 years would be $0.06,6.9,15.0$, and 6.3 acre-ft/yr, respectively.

Los Alamos Scientific Laboratory (Becker and others, 1981) projected aquifer response to future pumping and estimated the transmissivity to be 5,000 $\mathrm{gal} / \mathrm{d} / \mathrm{ft}\left(670 \mathrm{ft}^{2} / \mathrm{d}\right)$ and the storage coefficient to be $7 \times 10^{-2}$. For a total projected water use of about 480 acre-ft $\left(156.4 \times 10^{6} \mathrm{gal}\right)$ from 1981 through 1985 , the total water-level decline in the supply well was projected to be $41.6 \mathrm{ft}$. Actual withdrawal was somewhat different than projected withdrawal. Purtymun and others (1988, p. 14-15) reported an average annual withdrawal (1976-86) of about $5 \times 10^{6}$ gal that resulted in a water-level decline over the same period of about $17 \mathrm{ft}$.

\section{QUANTITATIVE MODELING OF THE GEOTHERMAL SYSTEM}

Various investigators have constructed quantitative models of the geothermal system in the Valles Caldera and surrounding region. The models represent combinations of (1) a conceptual framework of geologic and hydrologic conditions and (2) a mathematical representation of fluid flow, and sometimes heat flow, within the conceptual framework. In this section of the report, these two items are referred to as conceptual and numerical models, respectively. 
These existing models were developed primarily to provide assessments of reservoir productivity and longevity and the potential effects of development on thermal-water discharge to the Jemez River. Sufficient geologic and hydrologic data are available for this region to develop both simplified (one- and twodimensional) models and more detailed (two- and three-dimensional) models but not to adequately calibrate or test any of the models. As with other geothermal areas, the information needed to calibrate or test a model generally requires some level of exploitation of the geothermal reservoir and the resulting changes in the hydraulic and thermal regimes adequately delineated by monitoring.

Considering the above conditions, these model studies produced a wide range of answers related to the response of the hydrothermal system to development. Although geothermal fields in other parts of the world can provide insight into responses that might be expected for the Valles system, each geothermal field is sufficiently different that predevelopment predictions involve uncertainty. This is perhaps best exemplified by the unsuccessful attempt of Union Oil Company and the DOE to delineate a resource large enough to supply a planned 50-megawatt demonstration power plant, despite a favorable geologic setting (young silicic caldera in a region of extensional tectonics) and favorable temperature and productivity conditions in some wells.

This section briefly describes the main features, results, and limitations of existing models of the Valles geothermal system and outlines the elements required for successful modeling of the natural and exploited states of this system. However, a successful model of this type is one that can be modified or adjusted to simulate changes observed during at least the early stages of development.

\section{Conceptual Models of the Geothermal System}

Grant (1979) first suggested that the Valles system and other systems in areas of large topographic relief that overlie zones of upflow of deep, highenthalpy fluid are liquid dominated with a parasitic vapor-dominated zone, following the model for the geothermal system at Lassen Volcanic National Park, California (Ingebritsen and Sorey, 1985). The essential elements of this model (fig. 46) include an upflow zone and a region of two-phase (boiling) conditions at which steam and liquid phases separate, with steam rising through a vapor-dominated zone to discharge at high altitudes and liquid flowing laterally to discharge as springs and river seepage at low altitudes. Fluid pressures are distributed with depth as vaporstatic (region A), hydrostatic (region B), and superhydrostatic (region $C$ ). Actual gradients and pressures at each geothermal area depend on rock properties and fluid flow rates, but this general model accounts for several important features of this type of system: (1) discharge of neutral-pH, high-chloride water in thermal springs at considerable distance from the deep, high-temperature reservoir; (2) apparent underpressured conditions in the wells completed in the deep reservoir; and (3) hydrologic connections between areas of steam-heated thermal features, areas of high-chloride thermal springs, and underlying hightemperature liquid reservoir(s).
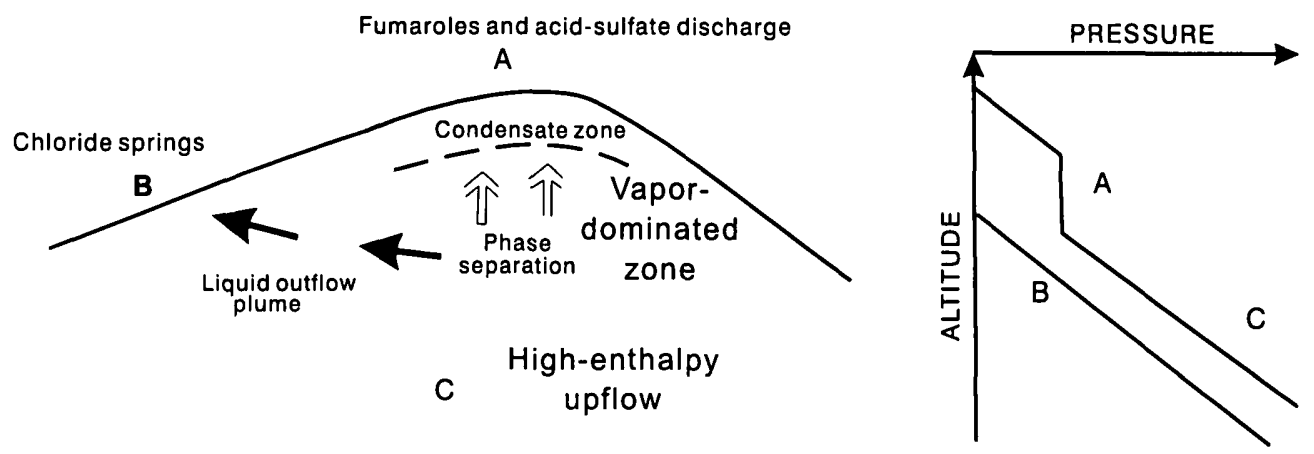

Figure 46.--Generalized pressure-altitude relations for liquid-dominated hydrothermal systems (modified from Grant, 1979). 
Grant and others (1984) delineated a vertical pressure gradient of $24.4 \mathrm{bars} / 1,000 \mathrm{ft}$ within the Redondo Creek subsystem or reservoir from analyses of well-bore measurements. Thermodynamic relations indicate that upflow would occur in regions where temperatures exceed $260^{\circ} \mathrm{C}$. This pressure gradient also extrapolates to zero pressure at an altitude of 7,900 $\mathrm{ft}$, which is about $1,100 \mathrm{ft}$ below land-surface altitudes in the Redondo Creek Graben, but about 1,500 $\mathrm{ft}$ above the level of thermal-spring discharge at Jemez Springs. This demonstrates how the geothermal reservoir can appear to be underpressured with respect to local landsurface altitudes but have enough head to drive what Goff and others (1988) referred to as a hydrothermal discharge plume. Well VC-1 (fig. 5) penetrated the discharge plume in the caldera's southwest moat; fluid samples from this well are chemically very similar to fluids sampled from the Redondo Creek wells. Flow conduits between the geothermal reservoir and distant areas of thermal-water discharge at a low altitude allow the reservoir to effectively be underpressured so that boiling and phase separation can occur at depth and a zone of steam upflow under vapor-static pressure conditions can develop. Studies reported by Goff and Shevenell (1987) and Goff and others (1992) of the ages of travertine spring deposits in Cañon de San Diego and fluid inclusions in well cores suggest that the present-day Valles hydrothermal system evolved over the past $0.5 \mathrm{Ma}$, following a depressurizing event associated with breaching of the southwest caldera wall and draining of intracaldera lakes.

This basic model for the Valles geothermal system needs to be modified to account for complications related to heterogeneity in thermodynamic and hydrologic conditions within the reservoir part of the system. For example, there appear to be separate productive zones at different depths within the Redondo Creek Graben area, although the well-pressure data interpreted by Grant and others (1984) suggest a degree of pressure communication between wells that penetrate different productive zones. Some measure of hydrologic separation may occur between the Redondo Creek area (graben) and the Sulphur Creek/west moat areas. Grant and others (1984) suggested, for example, that differences between the altitude of acid-sulfate springs in the Sulphur Creek area and the potentiometric surface in the Redondo Creek area are associated with the presence of a steam-dominated (vapor-static pressure) zone beneath the Sulphur Creek area and the absence of such a zone beneath the Redondo Creek area. Grant and others further suggested that the main zone of highenthalpy upflow is northwest of the Redondo Creek area and that this fluid flows laterally toward the Redondo Creek reservoir.

Goff and others (1992) used information from the more recently drilled wells VC-2A and VC-2B (fig. 5) and older wells in the west moat and beneath the Jemez Plateau west of the caldera to suggest that two separate subsystems, beneath Redondo Creek and Sulfur Creek, have developed in their own structural traps with separate recharge/discharge regimes. Furthermore, consistent differences in fluid chemistry observed between wells in the western part of the caldera and wells in the central part of the caldera imply the existence of two different discharge plumes, one flowing out the southwestern rim of the caldera and down Cañon de San Diego and the other flowing across the western rim and beneath the Jemez Plateau (Fraser Goff, oral commun., 1996). Although fluid in the latter plume may ultimately discharge to the Jemez River, its larger concentrations of conservative constituents (used in constituent-balance calculations to estimate thermal-water discharge to the river) could cause the total discharge to be overestimated by $10-15$ percent.

An additional complication is the presence of noncondensible gas $\left(\mathrm{CO}_{2}\right)$ in the reservoir fluid at Valles Caldera. Although concentrations of $\mathrm{CO}_{2}$ in this reservoir fluid have not been adequately delineated from existing sampling and wellhead measurements, sufficient amounts of gas appear to greatly extend the depth over which the vapor-phase condition occurs naturally and possibly to influence reservoir drawdown during development.

\section{Existing Numerical Mođels}

Numerical models of the Valles system and its response to development were described by Hartz (1976); Water Resources Associates, Inc. (1977); Balleau (1980); M.S. Gulati (Union Oil Company, written commun, 1980); Francis West (Office of the State Engineer, written commun., 1980); Union Geothermal Company of New Mexico (1981); Bodvarsson and others (1982); and Faust and others (1984). These models range in complexity from onedimensional, single-phase fluid-flow models to threedimensional, multiphase fluid and heat-flow models. Faust and others (1984) noted that differences in modeling approaches used in these studies resulted in a 
range from about 6.3 to $1,240 \mathrm{gal} / \mathrm{min}$ for the calculated depletion of thermal-water discharge to the Jemez River from 30-year simulations of geothermal development at the 50-megawatt level. (Most investigators reported depletion values in units of grams per second or kilograms per second; a fluid density of approximately 1 gram per cubic centimeter was assumed to convert the discharges into volume per unit time.) The models of Bodvarsson and others (1982) and Faust and others (1984), which are the only models that simulate possible production and injection scenarios over a 30-year period, give considerably different results of predicted reservoir drawdown and reservoir productivity over time.

The comparisons of Faust and others (1984) and Grant and others (1984) are summarized and values are indicated for thermal-water depletion and reservoir drawdown predicted by each study in table 19. The one-dimensional and (or) analytical models involve assumptions of constant net mass production from the Redondo Creek reservoir and uniform (but different) properties in the reservoir and outflow zones. The numerical model produced by the New Mexico State Engineer Office (1980) allows for two-dimensional fluid flow and variable hydraulic properties in the reservoir and outflow zones. The three remaining numerical models (Union Geothermal Company of New Mexico (1981); Bodvarsson and others (1982); and Faust and others (1984)) allow for multiphase fluid flow (steam and water) and heat flow in two or three dimensions and include specifications for inputs of high-enthalpy liquid at the base of the reservoir. All models are based on the assumption that zones of fluid flow, although containing regions of fracturecontrolled flow, can be treated as porous media at the scale of the model.

Considering the range of complexities in the different models, the results of predicted thermal-water depletion in the discharge in the Jemez River are not significantly different, except for the models of Hartz, Gulati, and Union Geothermal Company of New Mexico. The latter two models predict much less depletion because of inadequate treatment of twophase effects in the reservoir or insufficient simulation time. For the models by the New Mexico Office of the State Engineer; Water Resources Associates, Inc.; and Balleau differences in depletion predictions, from 365 to $1,240 \mathrm{gal} / \mathrm{min}$, could have been reduced and the predicted values brought more in line with that of the more complex three-dimensional simulation of Faust and others (1984) by adjusting assumed flow-zone parameters that could be justified with existing subsurface data. This raises the question of whether a more complex model is needed to address the effects of development on thermal springs. This issue is discussed in the final part of this section.

For simulations of changes in reservoir conditions and well productivity during development, the basic difference between the models of Faust and others (1984) and Bodvarsson and others (1982) is that in the former the reservoir is subdivided into four layers and in the latter it is treated as a single layer. Other differences are in assumed reservoir areas, total thickness, and permeability-thickness products. In general, the two-dimensional areal model of Bodvarsson and others yielded predictions of greater reservoir drawdown and shorter longevity than did the three-dimensional model of Faust and others (1984). Faust and others considered these differences to result primarily because Bodvarsson and others (1982) used a smaller permeability-thickness product and ignored vertical variations in thermodynamic conditions (steam fractions) within the reservoir.

\section{Quantitative Constraints}

Validation of the accuracy and applicability of predevelopment models requires a comparison of the models with quantitative constraints on the geothermal system. Such constraints typically are provided by measurements and estimates of rates of recharge and discharge of thermal fluid, hydraulic and thermal properties of reservoir rocks and fluids, and geologic and topographic controls on the geometry of the flow system. For the Valles geothermal system, enough information is available to construct scientifically defensible preliminary models at various levels of complexity, but not to provide enough quantitative constraints to adequately calibrate or test these models. What is still needed is some period of actual development in which the system is stressed and hydrologic changes are measured. This common situation is one for which preliminary models can still be useful for evaluating and designing potential development scenarios and monitoring schemes. Under such conditions, however, models cannot be expected to provide accurate answers to questions involving long-term changes to the hydrothermal system, including effects on surface features. 
Information available for the Valles system allows estimates to be made of the rates and locations of thermal-water discharge inside and outside the caldera, ranges of values for hydraulic and thermodynamic properties in the geothermal reservoir, and variations of possible geometric configurations for the areal and vertical extent of the reservoir and associated upflow zones. Of these values, the most accurately known appear to be those for thermal-water discharge in the Jemez River and for reservoir temperature and pressure distributions. Model simulations of changes in thermal-water discharge have for the most part yielded consistent results, in part because such predictions do not depend as much on detailed knowledge of conditions within the caldera. In contrast, the greater uncertainty in values and distributions of hydraulic properties of rocks and geologic limits on the flow system within the caldera has resulted in widely differing results from model simulations of reservoir response to development.

Results of constituent-balance calculations applied to the Jemez River and the Rio Grande show the following ranges of values for thermal-water discharge from the Valles hydrothermal system (Balleau, 1980; New Mexico State Engineer Office, 1980).

\begin{tabular}{cc}
\hline Site & Thermal-water discharge \\
\hline
\end{tabular}

Jemez River above San Ysidro 320-620 gal/min Jemez River at Rio Grande $\quad 900-1,580 \mathrm{gal} / \mathrm{min}$

The increase in thermal input downstream from San Ysidro apparently indicates that the zone of thermal-water discharge from the caldera is broad (not confined to Cañon de San Diego) and may include separate conduits at different depths. There may also be inputs of tracer ions (such as $\mathrm{Cl}$ and $\mathrm{B}$ ) from nonthermal sources within the drainage of the Nacimiento Mountains. Also, these calculations ignore the possibility of more than one reservoir source for the thermal water, as might be the case if discharge derived from the Sulfur Creek subsystem with somewhat different chemical composition flows westward and then southward eventually to enter the Jemez River. Nevertheless, the previous estimates provide useful constraints on models of the geothermal system, especially those constructed to evaluate the effects of geothermal development on natural thermal-water discharge.
Modeling studies by Faust and others (1984) and Balleau (1980) include somewhat independent calculations of thermal-water discharge under predevelopment conditions. In fact, the estimate of Faust and others (1984) of $790 \mathrm{gal} / \mathrm{min}$ for total thermal-water discharge from the hydrothermal system has been cited by some as the "best" value for this quantity. Although Faust and others said that their estimate was obtained by adjusting thermal-water throughflow within the reservoir to produce a match to known pressure and temperature distributions, a midrange (compared to constituent-balance results) value of $1,270 \mathrm{gal} / \mathrm{min}$ was possibly chosen for thermal input at the base of the model, and various properties (such as vertical permeability and thermal conductivity) were possibly adjusted to provide satisfactory matches to pressures and temperatures. Their model then simulates a total flow through the system and subsequent discharge to the Jemez River of approximately $790 \mathrm{gal} / \mathrm{min}$. This estimate is not so much an independently derived constraint as it is an indication that this model provides reasonable matches to predevelopment conditions.

Similarly, Balleau (1980) estimated the thermalwater discharge to the Jemez River upstream from San Ysidro to be $745 \mathrm{gal} / \mathrm{min}$, based on an equation derived from Darcy's law and taking into account estimates of transmissivity of the geothermal reservoir and head loss within the thermal flow system between the reservoir and San Ysidro. Balleau's estimated discharge is close to the estimated discharge of 628 $\mathrm{gal} / \mathrm{min}$ presented in the "Ground-water underflow" section (p. 90) of this report. Because of the uncertainty in actual values for each property used in the calculations (as well as limitations inherent in the simplified approaches), however, results differing by a factor of two could also be justified. Thus, this result serves mainly to indicate that discharge from the Valles geothermal system can reasonably account for the inputs of conservative constituents into the Jemez River.

\section{Modeling System Response to Development}

In general, the best approach to modeling systems such as the Valles geothermal system and its response to geothermal development is based on a viable conceptual model of the hydrogeologic framework that incorporates as much known information about the system as is required to 
adequately validate the model against the available quantitative constraints. The most detailed model is not always the best. For example, a numerical model with tens of thousands of grid blocks may be too cumbersome (and expensive) to test the sensitivity of model results to alternative boundary conditions or to variations in model properties. At the other extreme, a simple, one-dimensional analytical solution for drawdown and streamflow depletion tends to be too poorly constrained to offer any quantifiable measure of the accuracy of its predictions; this could change, however, if the response of the system to production was measured during the early stages of development.

Elements necessary for successful modeling of this type of system include (1) three-dimensional descriptions of fluid and heat flow that can treat both lateral and vertical heterogeneities, (2) a multiphase thermodynamic and fluid-flow formulation, (3) hydrologic continuity between the geothermal reservoir and the discharge plume of thermal water in areas inside and outside the caldera, (4) capability to allow for variable input rates of high-enthalpy fluid into the geothermal reservoir, and (5) capability to treat different production/injection scenarios as affected by changes in steam fractions in regions around production wells. The model of Faust and others (1984) has these capabilities yet is simple enough that it can be used to test combinations of different parameters or to examine the importance of two-phase effects and vertical variations in reservoir properties and fluid (thermodynamic) states in modeling the reservoir response to development.

For two-phase effects, early modeling studies carried out by Union Oil Company predicted that reservoir pressures would decline during development until the fluid reached the boiling point and that subsequently reservoir pressures would cease declining because of the large effective compressibility of twophase fluid. Because the high-temperature reservoir fluid at Valles initially is close to the boiling point, this type of analysis predicts little drawdown of reservoir pressure and hence predicts only minor declines in thermal-water discharge outside the caldera. This reasoning appears to have formed the basis for the finding by the New Mexico State Engineer Office (1980) that the decrease in thermal-water discharge upstream from San Ysidro would amount to only about 15 percent following geothermal development. More recent numerical model studies have clearly demonstrated that the formation of two-phase zones in response to production would be localized around production wells and not spread uniformly through the reservoir. Consequently, reservoir drawdown would not stop when the boiling point is reached and may in fact accelerate because of the nature of steam/water relative permeability functions.

The more detailed numerical models have demonstrated that injection of liquid in wells south and southwest of production wells in the Redondo Creek Graben may actually result in pressure increases and increases in thermal-water discharge to the Jemez River during the first few years of injection. This effect is overcome in later model simulation years by the spread of the drawdown region created by the production wells. These results imply, however, that placement of some injection sites closer to the thermal springs along the Jemez River could ultimately be used to prevent negative effects on these springs from longterm geothermal development.

The detailed numerical models of Faust and others (1984) and Bodvarsson and others (1982) predict significantly different reservoir response to development in terms of degree of drawdown and longevity of the field (time period until reservoir pressure falls too low to sustain adequate steam production). Faust and others (1984) criticized the earlier results as overly pessimistic because the value of reservoir thickness used was too small and because vertical variations were not considered. Subsequent events, however, suggest that the earlier study that cast doubt on the ability of the Valles system to sustain a 50megawatt power plant may have had some validity.

Interestingly, the greatest reservoir longevity in the study by Bodvarsson and others (1982) involved input of hot water at the base of the model at rates that increased with time from 0 to $790 \mathrm{gal} / \mathrm{min}$. Similarly, this recharge of hot water is also an important aspect of the model of Faust and others (1984), who settled on a constant input of $1,050 \mathrm{gal} / \mathrm{min}$. In the undeveloped state, this input supplies the throughflow of thermal water that ultimately discharges in thermal springs or streams. Experience gained modeling other systems following periods of development indicates that the rate of thermal-water input likely will increase as a result of pressure declines in the reservoir during development. In some cases, this increased input can become a very significant fraction of the net fluid produced and hence can exert a strong influence on the level of drawdown. Also, reservoir drawdown could induce inflow of cooler water from shallower regions into the production zone. Neither of these processes has 
been simulated in the modeling studies thus far completed for the Valles system.

Finally, existing models do not account for the presence of $\mathrm{CO}_{2}$ in reservoir fluid. During model development, Grant and others (1984) suggested that reservoir pressure changes could be significantly influenced by the presence of dissolved gas. They cited the example of the Broadlands field in New Zealand where gas contents were twice as large as at the Valles geothermal system and pressure changes during the early stages of production were dominated by gas partial-pressure effects. The numerical study by Pritchett and others (1981) indicates that such effects increase the two-phase region near production wells and increase reservoir pressure declines. Faust and others (1984) suggested that the actual distribution of $\mathrm{CO}_{2}$ concentrations in Valles reservoir fluids is not adequately known and that some indications of large gas concentrations in water sampled from wells may not actually exist in the liquid-dominated parts of the reservoir. This matter requires further study because more accurate simulation of reservoir performance and longevity is needed and because model predictions of changes in thermal-water discharge are strongly dependent on the level and distribution of reservoir drawdown resulting from development.

\section{MONITORING HYDROCHEMICAL DISCHARGE IN THE SOUTHWESTERN JEMEZ MOUNTAINS}

Development of geothermal energy in or near Valles Caldera possibly would change the hydrochemical discharge from the southwestern Jemez Mountains. Detection of and tracking such change would require systematic monitoring. The information gained from such monitoring would be valuable in better understanding the geothermal system and in testing, refining, and calibrating numerical models of the system. Several components of a monitoring system are already available as a result of past and ongoing data collection in the region (table 20). Extension and some modification of these activities could provide monitoring of most chemical transport in surface water and much of the transport in ground water.

Effective monitoring of a complex geohydrologic system requires prior understanding of the system. In many areas, including the Jemez Mountains, the knowledge available initially may be inadequate for the design of all aspects of a monitoring plan, and the plan may need some modification as the work progresses. For this reason, and because of the desirability of a period of record antecedent to anticipated development, a monitoring program would need to begin as promptly as is practicable after the need for it has been recognized.

Surface drainage, which receives much of the subsurface drainage before leaving this region, is accomplished by the Jemez River and its tributary, the Rio Guadalupe. The combined flow of these streams, which join north of Cañon and Jemez Pueblo (fig. 47), is measured at the USGS streamflow-gaging station Jemez River near Jemez (08324000).

Two principal tributaries of the Jemez River drain Valles Caldera: San Antonio Creek drains the northern moat area and its adjacent slopes and the East Fork Jemez River drains the southern moat area and its adjacent slopes. Both are fed principally by dilute spring waters of shallow origin, but San Antonio Creek also receives the flow of two small streams from the west side of Redondo Peak-Sulphur and Redondo Creeks. Sulphur Creek flows through the Sulphur Springs area, and Redondo Creek drains the faulted terrain on Redondo Peak where most of the exploratory geothermal drilling has been done. Upstream from Soda Dam these small streams contribute much of the $\mathrm{SO}_{4}$ and $\mathrm{Cl}$ carried by the Jemez River; downstream from the dam the mineral springs at Soda Dam and Jemez Springs contribute most of the dissolved load.

The Rio Guadalupe drains much of the region west and southwest of the caldera. It contributes, on average, about two-thirds of the streamflow recorded at Jemez River near Jemez but about half the dissolvedconstituent load. Abundant data for Rio Guadalupe Basin show no evidence of a natural geothermal contribution to streamflow and dissolved load. Geothermal effluent detected at the Jemez River near Jemez (08324000) site is transported by the Jemez River upstream from the junction with the Rio Guadalupe.

Hydrochemical changes in the Jemez River and Rio Guadalupe systems can be identified and tracked most effectively by monitoring streamflow and water quality at selected gaging stations and supplementing those observations with surface- and ground-water data within their corresponding basins. Data collected at Jemez River below East Fork, near Jemez Springs (08321500), for example, indicate changes in hydrochemical discharge during the last 30 years; consideration of these records provides insight into the monitoring problem. 
Table 20. Selected periodic measurement sites at which streamflow and water-chemistry data have been collected

\begin{tabular}{|c|c|c|c|}
\hline $\begin{array}{c}\text { Site } \\
\text { identifier } \\
\text { (fig. 47) }\end{array}$ & Site name & $\begin{array}{l}\text { Discharge } \\
\text { data }^{1}\end{array}$ & $\begin{array}{l}\text { Source of } \\
\text { chemical } \\
\text { data }^{2}\end{array}$ \\
\hline 1 & San Antonio Hot Spring & No & $\mathrm{L}$ \\
\hline 2 & San Antonio Creek above Sulphur Creek & No & $\mathrm{L}, \mathrm{G}$ \\
\hline 3 & $\begin{array}{l}\text { Sulphur Creek above Redondo Creek } \\
\text { Redondo Creek above Sulphur Creek } \\
\text { (near gaging station 08319945) } \\
\text { Sulphur Creek above San Antonio Creek } \\
\text { (near gaging station 08319950) }\end{array}$ & $\begin{array}{l}\text { No } \\
\text { No }\end{array}$ & $\begin{array}{l}\mathrm{L} \\
\mathrm{L}\end{array}$ \\
\hline 4 & Wells and springs near La Cueva & No & $\mathrm{L}$ \\
\hline 5 & Spence Spring & No & $\mathrm{L}$ \\
\hline 6 & $\begin{array}{c}\text { Jemez River above East Fork } \\
\text { Jemez River below East Fork } \\
\text { (gaging station 08321500) }\end{array}$ & $\begin{array}{l}\text { Yes } \\
\text { Yes }\end{array}$ & $\begin{array}{l}\mathrm{L}, \mathrm{G} \\
\mathrm{L}, \mathrm{G}\end{array}$ \\
\hline 7 & McCauley Spring & Yes & $\mathrm{L}, \mathrm{G}$ \\
\hline 8 & Limestone Spring near Battleship Rock & No & $\mathrm{G}$ \\
\hline 9 & Test well near Battleship Rock & No & G \\
\hline 10 & Sino Spring & No & $\mathrm{G}$ \\
\hline 11 & Agua Durme Spring & No & $\mathrm{L}$ \\
\hline 12 & $\begin{array}{l}\text { Springs at Soda Dam } \\
\text { Jemez River above Soda Dam } \\
\text { Jemez River below Soda Dam }\end{array}$ & $\begin{array}{l}\text { Yes } \\
\text { Yes } \\
\text { Yes }\end{array}$ & $\begin{array}{l}\text { L, G } \\
\text { G } \\
\text { G }\end{array}$ \\
\hline 13 & Springs in Church Canyon & No & $\mathrm{L}$ \\
\hline 14 & $\begin{array}{l}\text { Jemez Springs } \\
\text { Jemez Springs below Jemez Springs }\end{array}$ & $\begin{array}{l}\text { Yes } \\
\text { Yes }\end{array}$ & $\begin{array}{l}\mathrm{G} \\
\mathrm{G}\end{array}$ \\
\hline 15 & Jemez River above Rio Guadalupe & No & $\mathrm{L}$ \\
\hline 16 & Spring (tank), Lake Fork Canyon & No & $\mathrm{L}$ \\
\hline 17 & Stream sampling sites in Lake Fork Canyon & No & $\mathrm{L}$ \\
\hline 18 & Spring, Lake Fork Canyon & No & $\mathrm{L}$ \\
\hline 19 & Rio Cebolla below Lake Fork Canyon & No & $\mathrm{L}$ \\
\hline 20 & Rio Guadalupe above Jemez River & No & $\mathrm{L}$ \\
\hline 21 & $\begin{array}{l}\text { Jemez River near Jemez } \\
\quad \text { (gaging station } 08324000 \text { ) }\end{array}$ & Yes & $\mathrm{L}, \mathrm{G}$ \\
\hline 22 & Jemez River at Highway 4 near San Ysidro & No & G \\
\hline
\end{tabular}

${ }^{1}$ Discharge measurements by the U.S. Geological Survey.

${ }^{2}$ Agency collecting water-chemistry data: L, Los Alamos National Laboratory; G, U.S. Geological Survey. 


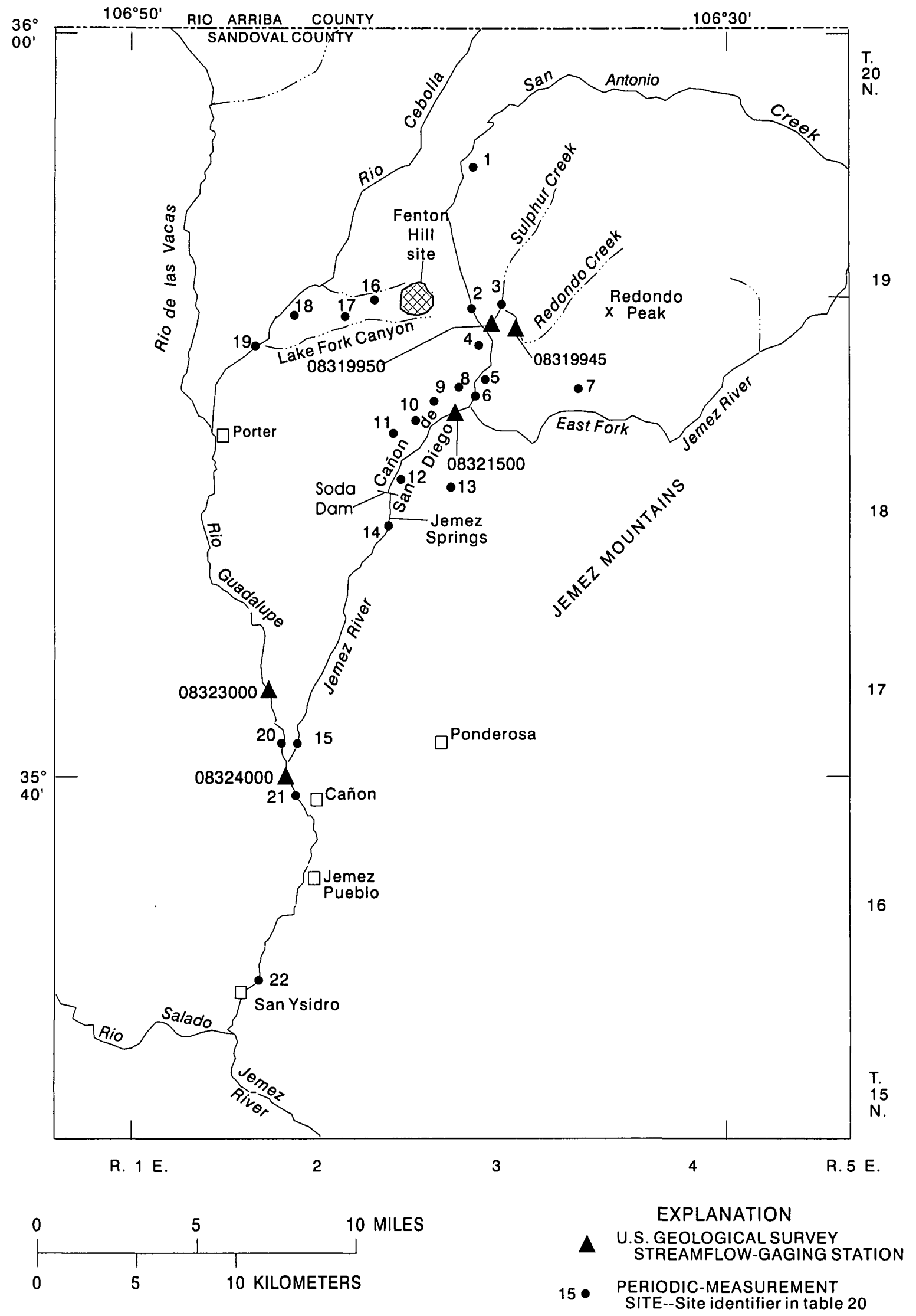

Figure 47.--Selected streamflow-gaging stations and periodic-measurement sites where hydrologic measurements have been made. 


\section{HISTORICAL MONITORING}

The $\mathrm{Cl}$ load at the Jemez River below East Fork, near Jemez Springs for 1963-67 and 1971-82 is plotted in figure 4B. The 1963-67 chloride loads are in two overlapping groups with respect to magnitude. $\mathrm{Cl}$ load in the two groups is similar, but the more abundant samples containing smaller loads are characterized by low stream discharge (mean about $13 \mathrm{ft}^{3} / \mathrm{s}$ ). The few samples containing large loads occur at higher discharge (mean about $32 \mathrm{ft}^{3} / \mathrm{s}$ ). The smaller stream discharge occurs when ground-water inflow to the stream provides all or most of the base flow. The larger stream discharge represents periods of surface runoff from storms and melting snow. Considering the range in conditions and the few data available, particularly for the larger discharge, determining a representative mean value for $\mathrm{Cl}$ load is difficult. The dashed trend line in figure 48, extending through the group of smaller values for 1963-67, implies that the magnitude of $\mathrm{Cl}$ load was relatively stable during periods of base runoff.

Further examination of chloride-load plots requires consideration of the source of $\mathrm{Cl}$ transported by the Jemez River past gaging station 08321500 (fig. 47). Atmospheric deposition by rain and snow accounts for the larger part of $\mathrm{Cl}$ found in dilute water in the Jemez Mountains. Chloride also may be derived from the near-surface rocks by weathering, but that process is unimportant quantitatively because $\mathrm{Cl}$ occurs in the volcanic rocks in only trace concentrations (Gardner and others, 1986).

Chloride concentration in 144 samples collected from springs and headwater streams fed by shallow ground water (Purtymun and others, 1974-76, 1978, 1980a, b, 1981, 1983; Trainer, 1978, table 5; Shevenell and others, 1987, table B-II) ranges from less than 1 to $14 \mathrm{mg} / \mathrm{L}$ (mean value $4.7 \mathrm{mg} / \mathrm{L}$, median value $4 \mathrm{mg} / \mathrm{L}$ ). These springs and streams drain volcanic rocks, sandstone-shale, and limestone. Eight samples of snow collected in Valles Caldera in 1974 contained 0.05 to $0.70 \mathrm{mg} / \mathrm{L} \mathrm{Cl}$ (Trainer, 1978, table 10). This small suite of samples is not representative of long-term conditions because the samples probably represent only two or three storms; thus, the large suite of 144 samples from springs and streams is more representative of atmosphere-derived chloride.
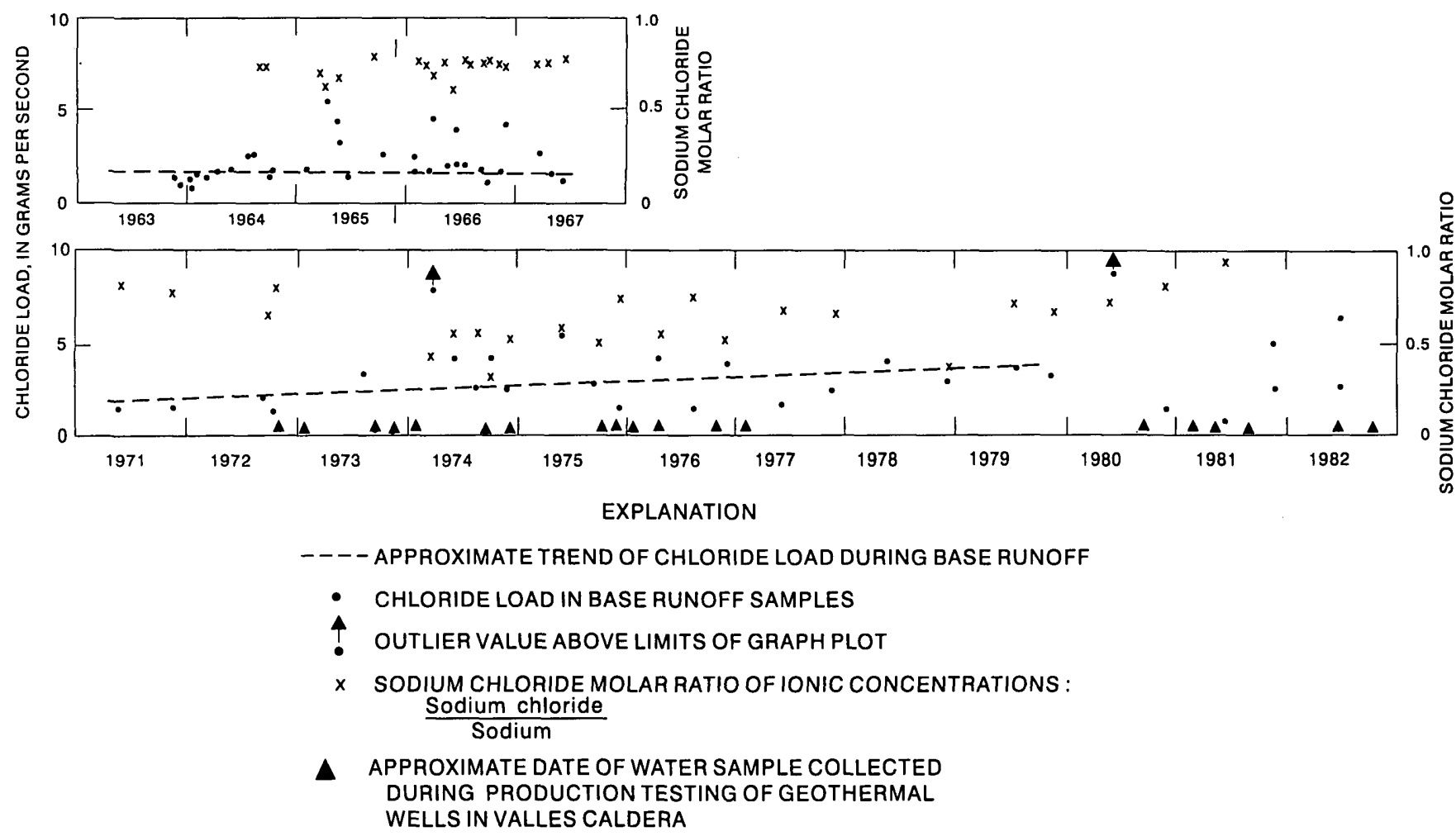

Figure 48.--Chloride load and sodium chloride molar ratio at the Jemez River below East Fork, near Jemez Springs for 1963-67 and 1971-82. 
The rather wide range in concentration in the suite of 144 samples is attributed to a particular aspect of the chloride cycle in ground water in this region. Chloride is a conservative constituent when dissolved in water - that is, it is carried advectively in moving water, is not precipitated chemically, and is not absorbed on grain surfaces in host materials. However, there is a short-lived exception to this generalization. In a semiarid region much of the precipitation that infiltrates land surface is promptly removed by evaporation, and dissolved constituents concentrate in the soil. The constituents are then available for mobilization and removal by shallow unsaturated flow and surface runoff during the next storm. The larger concentrations of $\mathrm{Cl}$ in the dilute water are attributed to this mechanism.

The Na load would be expected to be larger than the $\mathrm{Cl}$ load at the gaging station Jemez River below East Fork as a result of $\mathrm{Na}$ being released by weathering of minerals, particularly feldspars in the volcanic rocks. If all $\mathrm{Cl}$ in streamflow is assumed to have come from atmospheric precipitation, then the ratio $(\mathrm{Na} \mathrm{Cl}) / \mathrm{Na}$ (concentrations in equivalent weights) expresses the "excess" $\mathrm{Na}$ that was derived from weathering. Where there is little excess $\mathrm{Na}$ the ratio approaches zero; where excess $\mathrm{Na}$ is larger, the ratio is significantly greater than zero and can approach one. Ratios of approximately 0.7 to 0.8 are common in the local dilute water thought to contain no geothermal component (see plot of 1963-67 data in fig. 48). Concentrations of $\mathrm{Na}$ and $\mathrm{Cl}$ (in equivalent weights) in geothermal reservoir fluids are approximately equal (figs. 15 and 23); consequently the ratio $(\mathrm{Na} \mathrm{Cl}) / \mathrm{Na}$ of geothermal fluid is close to zero and in some samples may be a small negative number. The addition of geothermal fluid to the dilute stream water, therefore, will result in a reduction of the $(\mathrm{Na} \mathrm{Cl}) / \mathrm{Na}$ ratio of the mixed stream water. Because $\mathrm{Na}$ and $\mathrm{Cl}$ concentrations in geothermal fluids are much larger than in stream water, a small addition of geothermal fluid can cause an appreciable shift in the $(\mathrm{Na} \mathrm{Cl}) / \mathrm{Na}$ ratio.

Drilling and testing of geothermal wells in Valles Caldera began in 1960; four wells were drilled during 1960-64, followed by a hiatus before more intensive drilling began in 1970. Several wells underwent lengthy production testing. Not all water produced could be returned to the reservoir by injection, so part of it was stored in ponds retained behind earthen dams. Because storage ponds are likely to leak over time or may overtop their dams during storms, small volumes of geothermal fluid possibly entered the stream system.

The chloride-load plot for Jemez River below East Fork, near Jemez Springs (fig. 48) can be interpreted in terms of pond leakage. According to this interpretation, the record of $\mathrm{Cl}$ load for 1963-67 represents near-normal conditions, and the $(\mathrm{Na} \mathrm{Cl}) / \mathrm{Na}$ ratios during this period were typically about 0.7 to 0.8 . During the 1970's, disturbance of the natural $\mathrm{Na} \mathrm{Cl}$ concentration in the stream became more pronounced, as revealed by the wider range in the $(\mathrm{Na} \mathrm{Cl}) / \mathrm{Na}$ ratios, from 0.3 to 0.9 . Production testing was sufficiently frequent during the 1970's that the stream may have been receiving $\mathrm{Na} \mathrm{Cl}$-charged geothermal fluid more or less continuously throughout much of the period after 1972 to the early 1980 's.

Determining mean values of $\mathrm{Cl}$ loads during 1971-82, for which few samples are available, and identifying any load trends during that period are even more difficult than for 1963-67. The dashed trend line through base-flow samples in figure 48 suggests a steadily rising trend in chloride loads during 1971-79. The increasing chloride loads cannot be accounted for by increasing runoff, but the increasing loads are consistent with geothermal fluids with large chloride concentrations entering the stream.

The three gaging stations- the Jemez River near Jemez (08324000); Rio Guadalupe at Box Canyon, near Jemez (08323000); and Jemez River below East Fork (08321500)—provide most of the data for the preceding discussion of interpretation of discharge and hydrochemical data, although short periods of data also are available for Redondo Creek (08319945) and Sulphur Creek (08319950) (fig. 47).

Data for two other types of activities also aid in the design of a monitoring system: periodic measurements of streams, wells, and springs and inventories of hydrologic features that include repeated, but generally not systematic, measurements.

Two investigations conducted periodic measurements at selected sites in the southwestern Jemez Mountains. The LANL began systematic observations in 1973 in support of the laboratory's hotdry-rock experiments at the Fenton Hill site (fig. 47). These observations were summarized by Purtymun and others (1974) and in a series of mostly annual reports (Purtymun and others, 1975-76, 1978, 1980, 1981, $1983,1987,1988)$. The data, which represent streams, wells, springs, and soil and vegetation, consist primarily of chemical analyses. In 1972-75 the USGS 
investigated geothermal hydrology in the Jemez Mountains outside Valles Caldera. As part of that study the USGS monitored selected streams, wells, and springs for discharge and water quality (Trainer, 1978, 1984).

The LANL and USGS monitoring activities were coordinated on their inception in 1972-73. Both programs used the continuous streamflow records provided by the USGS gaging stations, and a degree of overlap was planned in monitoring other sites. The LANL has expanded its monitoring network substantially since measurements began. The inventories of hydrologic features (Trainer, 1978; Shevenell and others, 1987) are useful in planning monitoring programs because they contain a broad range of background data covering much of the region and include a few sets of repetitive measurements that supplement time series of data collected as part of the monitoring activities.

The LANL hot-dry-rock experiment, for which the first test holes were drilled in 1972, has consisted essentially of drilling a pair of deep holes into "dry" crystalline rock at a site just outside the west rim of Valles Caldera; creating a flow path between the wells at depth by hydro-fracturing; connecting the wells with piping at land surface; and circulating water through this closed loop and recovering heat from the return water at the surface. Representative reports that describe the initial development and testing include West (1974), Pettitt (1975a, b; 1978), West and others (1975), and Dash and others (1983). The following summary is based on information by Purtymun and others $(1974,1975-76,1978,1980,1981,1983,1987$, 1988).

Large volumes of waste material have been produced during drilling and testing of the wells at the Fenton Hill site: rock cuttings, drilling mud and cementing materials, and mineralized water recovered from closed-loop circulation experiments. The sediment-laden and mineralized water was stored temporarily in pits excavated at the Fenton Hill site. Part of the solid material in the pits was excavated and buried. Part of the liquid waste infiltrated the tuff beneath the ponds, part of it evaporated, and part was released down Lake Fork Canyon (fig. 47). The canyon floor is dry except during runoff from melting snow and rainstorms, and it was anticipated that the water released would infiltrate alluvium in the canyon or be diluted and removed by surface runoff. Water release was approved by the U.S. Forest Service.
The possibility of both planned release and accidental escape of liquid wastes was the stimulus for establishment of the LANL monitoring study. The liquid wastes contain two assemblages of dissolved constituents: (1) constituents derived from cements and drilling fluids-largely $\mathrm{Ca}, \mathrm{HCO}_{3}$, and $\mathrm{SO}_{4}$ and (2) moderate to large concentrations of constituents typical of geothermal fluid in this region, such as $\mathrm{Na}, \mathrm{Cl}, \mathrm{F}, \mathrm{B}$, and $\mathrm{Li}$, attributed to dissolution of crystalline rock during circulation and heat-transfer experiments in the deep wells. The principal-constituent composition of the mixed wastes (fig. 49) so resembles that of natural geothermal fluid as to suggest that short-term flow of dilute water through artificial fractures in hot, impermeable, unweathered granitic rock can form a suite of dissolved constituents superficially similar to that produced by long-term "cooking" within the Valles geothermal reservoir. Summaries by Purtymun and others $(1976,1980 \mathrm{a}, \mathrm{b}, 1983,1987)$ show that release of ponded water began as early as 1975; soluble compounds of $\mathrm{Cl}$ and $\mathrm{F}$ were detected in soil as far as $1,000 \mathrm{ft}$ from the site down Lake Fork Canyon by 1978 (fig. 47). Maximum concentrations of dissolved constituents in the discharged waste in 1979 include $\mathrm{Cl}$, $745 \mathrm{mg} / \mathrm{L} ; \mathrm{F}, 7.3 \mathrm{mg} / \mathrm{L} ; \mathrm{As}, 0.49 \mathrm{mg} / \mathrm{L} ; \mathrm{B}, 63 \mathrm{mg} / \mathrm{L} ; \mathrm{Cd}$, $0.014 \mathrm{mg} / \mathrm{L} ; \mathrm{Li}, 20 \mathrm{mg} / \mathrm{L} ;$ and dissolved solids, 4,860 $\mathrm{mg} / \mathrm{L}$. In 1982 high concentrations of several trace constituents were detected in soil, roots, and foliage within several hundred meters downcanyon from the waste ponds; no effect of the discharge was detected in streams or springs farther downcanyon. Nonetheless, the volumes of water released are substantial- 1.02 million gal in 1981 and 0.6 million gal in 1982.

\section{SUMMARY}

The Jemez Mountains in north-central New Mexico contain a hot-water geothermal system that was explored between 1970 and 1982 as a source of geothermal energy. This report summarizes the geothermal system and presents and discusses results of a 1972-75 USGS study. The report discusses the geothermal hydrology of a large central caldera known as the Valles Caldera, which contains the principal geothermal reservoir, and the southwest Jemez Mountains, which receive geothermal discharge from the reservoir. The Valles geothermal system and reservoir are located in the central and western parts of the caldera. 


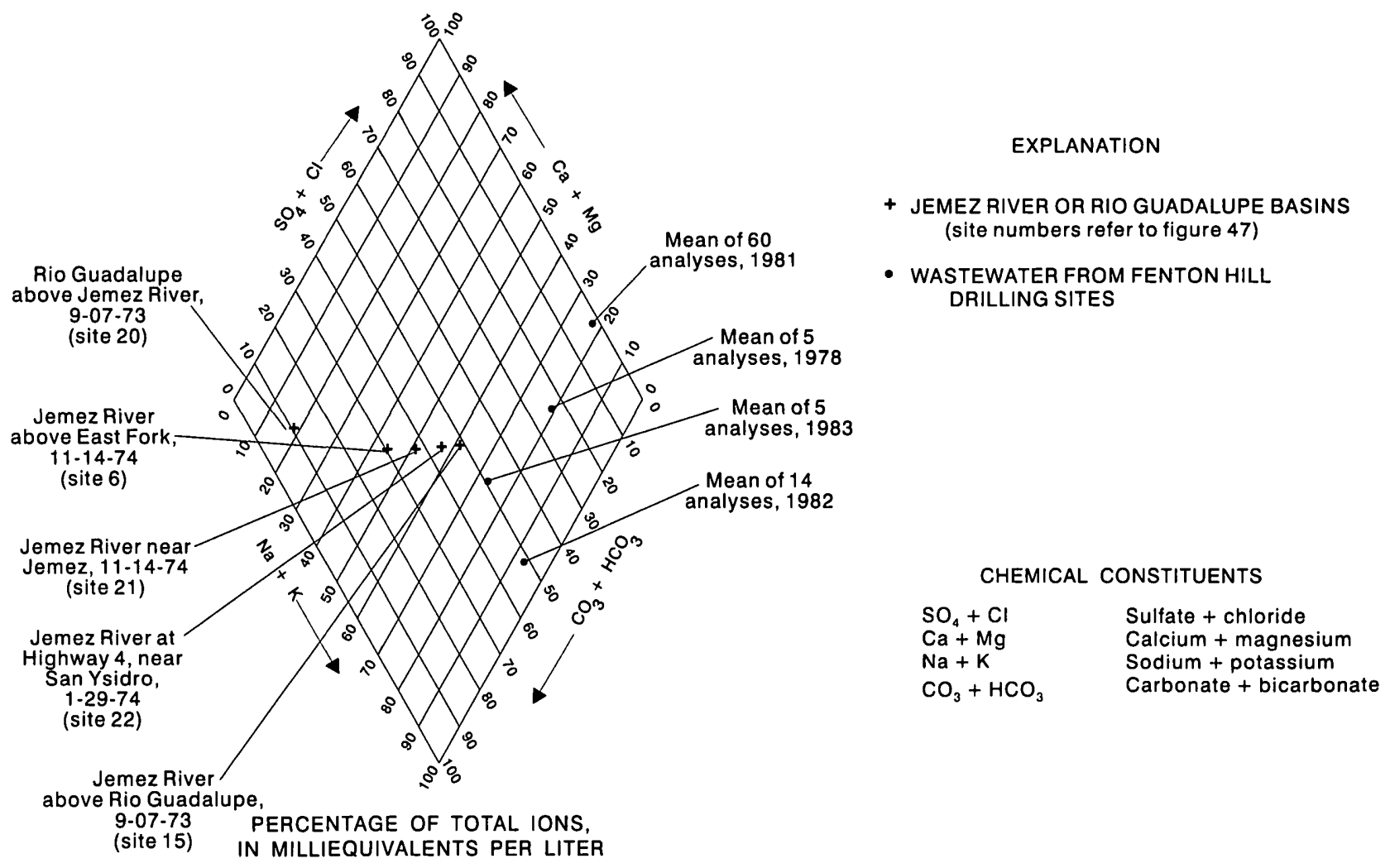

Figure 49.--Relation of major-ion composition in water samples from the Jemez River and Rio Guadalupe Basins and wastewater from Fenton Hill drilling sites (data from Trainer, 1978; and Purtymun and others, 1980a,b, 1983, and 1987). Surface-water sampling sites shown in figure 47.

The Jemez Mountains are a complex assemblage of Tertiary and Quaternary volcanic rocks that overlie Tertiary, Mesozoic, and Paleozoic sedimentary rocks and Precambrian crystalline rocks. The mountains form an oval topographic mound that occupies about $1,500 \mathrm{mi}^{2}$ and contains the Valles Caldera. The topographic rim of the caldera is approximately circular and about 14 to $18 \mathrm{mi}$ in diameter. The ringfracture zone, along which the caldera floor has collapsed, is about 8-10 mi in diameter. A resurgent dome known as Redondo Peak occupies about onefourth of the caldera.

The topographic rim of Valles Caldera forms a near-circular drainage basin with a surface outlet on the southwest. Two principal streams-San Antonio Creek and the East Fork Jemez River-drain the caldera and join near the southwest rim to form the Jemez River, which flows down Cañon de San Diego, then east to join the Rio Grande. The caldera contains both thermal and nonthermal ground water, and both types of ground water discharge to the southwest as ground-water underflow beneath Cañon de San Diego, which follows the trace of the Jemez Fault Zone. In other areas outside the rim, ground water flows radially away from the caldera.

Several distinct types of nonthermal and thermal ground water are recognized in the Jemez Mountains. Nonthermal ground water in Valles Caldera occurs in diverse perched aquifers and deeper valley-fill aquifers. Recharge occurs principally by infiltration of precipitation on surrounding mountain slopes, alluvial fans, and benches. Natural discharge occurs as spring flow, seepage to the major streams draining the valleys, and as downward leakage to the deeper geothermal reservoir.

The near-surface thermal water in the caldera is grouped into two types based on geochemistry and geohydrology: thermal meteoric water and acid sulfate water. Thermal meteoric water, heated by the high conductive heat flux in that area, discharges from fractures in rhyolite and from contacts between rhyolite and underlying sedimentary rocks in the ring-fracture 
zone of the western and southwestern parts of the caldera. Geochemical data indicate that thermal water circulates within the upper $1,500 \mathrm{ft}$ of the caldera moat and generally entered the ground-water system more than 50 years prior to its discharge at the springs.

Acid sulfate water is characterized by low $\mathrm{pH}$ ( 0.6 to 5$)$ and by large concentrations of sulfate (greater than $1,000 \mathrm{mg} / \mathrm{L}$ ). Acid sulfate water issues from fractures and faults on the western slope of the resurgent dome, principally in the Sulphur Springs area. Sulphur Springs is the most active zone of surface thermal manifestations in the caldera and contains thermal and nonthermal springs, mud pots, and fumaroles. These thermal features are manifestations of an underlying vapor-dominated zone.

High rates of near-surface heat flow and high subsurface temperatures characterize the western half of Valles Caldera and adjacent parts of Jemez Plateau to the west. Heat flow increases markedly as the rim of the caldera is approached from the west, and temperature gradients within the caldera are markedly greater than those outside the caldera rim.

The main geothermal reservoir is recharged by meteorically derived water. The water moves downward from the overlying aquifers in the caldera fill and laterally recharges the geothermal reservoir in intracaldera tuffs and precaldera rocks at depths of $6,500 \mathrm{ft}$ or more and at temperatures reaching $330^{\circ} \mathrm{C}$. The heated geothermal water subsequently rises convectively to depths of about $2,000 \mathrm{ft}$ or less. A vapor-dominated zone (or zones) containing steam, $\mathrm{CO}_{2}$, and other gases has formed above parts of the liquid-dominated zone, most notably in the Sulphur Springs area. The heated water of the geothermal system flows out the caldera to the west and southwest under the Jemez Plateau and along the Jemez Fault Zone and in the semipermeable Paleozoic rocks that border the fault zone.

Two important subsystems have been identified within the larger geothermal system: the Redondo Creek subsystem under the central part of the resurgent dome and the Sulphur Creek subsystem under the northwestern part of the dome. Permeability of the Redondo Creek subsystem is controlled by both stratigraphic and fault-related structures.

Stratigraphically controlled permeability occurs in tuffaceous sandstones and nonwelded tuff units spaced throughout the Bandelier Tuff. At least two main zones of permeability exist: a deeper zone about $500 \mathrm{ft}$ thick at the contact between the Bandelier Tuff and the underlying Paliza Canyon Formation and a generally more productive upper zone within the Bandelier Tuff. Most of the permeability is produced by the high-angle, normal faults and associated fractures that form the Redondo Creek Graben.

The Sulphur Springs subsystem is not as well defined as the Redondo Creek subsystem. Faults and related fractures control the flow of thermal fluids in the subsystem, which is bounded by grabenlike faults. An upper vapor-dominated zone is separated from the liquid-dominated zone by about $800 \mathrm{ft}$ of sealed caldera-fill rock. Chemical and thermal evidence indicates that the Sulphur Springs subsystem may be isolated from the Redondo Creek subsystem, and each may have its own zone of upflow and lateral discharge.

Estimates of the area and thickness of the geothermal reservoir vary. The area of the entire reservoir is estimated to be between 12 and $15 \mathrm{mi}^{2}$ by recent investigators, and its western limit is thought to be at the ring-fracture zone of the caldera. Most investigators place the top of the reservoir at the bottom of a small-permeability "caprock" that is about 2,000 to $3,000 \mathrm{ft}$ below land surface. The bottom of the reservoir is more difficult to define. Estimated thickness of the bottom of the reservoir ranges from 2,000 to $6,000 \mathrm{ft}$. Reservoir temperatures measured in wells ranged from $225^{\circ} \mathrm{C}$ just below the caprock to about $330^{\circ} \mathrm{C}$ in deeper wells. Pressures measured in exploration wells in the $\mathbb{R e d o n d o}$ Creek area ranged from 450 to 1,850 $\mathrm{lb} / \mathrm{in}^{2}$.

The geochemistry of water in the geothermal reservoir is typical of volcanic geothermal water. The reservoir contains a near-neutral, chloride-type water containing about $7,000 \mathrm{mg} / \mathrm{L}$ dissolved solids and anomalously large concentrations of $\mathrm{As}, \mathrm{B}, \mathrm{Br}, \mathrm{Cs}, \mathrm{Li}$, $\mathbb{R b}$, and other trace elements. Thermal spring water in the caldera has no geochemical characteristics similar to those of the geothermal reservoir fiuids sampled from wells.

Oxygen-18 and deuterium concentrations of geothermal reservoir fiuid support a meteoric origin. The geothermal fluid is enriched in ${ }^{18} \mathrm{O}$ relative to the meteoric-water line for the Jemez Mlountains region, and the amount of enrichment is typical of that measured in other geothermal systems.

The entire caldera depression and surrounding rim of highlands are thought to serve as the recharge area; the moat valleys in north and east areas may be the principal recharge zones of the reservoir.

Downward flow along fault zones and fractures 
probably is the primary mechanism of recharge. The recharge probably flows downward around the outer edges of the reservoir or along the caldera ring fractures, enters the reservoir at depth where it is heated, then rises convectively within the reservoir.

Pressure measurements in wells in the Redondo Creek area and in Baca wells 7 and 8 define a consistent gradient within the reservoir that corresponds to a hydrostatic gradient at approximately $260{ }^{\circ} \mathrm{C}$. The gradient extrapolates to atmospheric pressure at 1,100 $\mathrm{ft}$ below a land-surface altitude of $9,000 \mathrm{ft}$ in the Redondo Creek graben but about $1,500 \mathrm{ft}$ above the level of thermal discharges at Jemez Springs. The pressure gradient indicates upward flow in regions where temperatures exceed $260^{\circ} \mathrm{C}$. Flow conduits between the geothermal reservoir and distant areas of thermal-water discharge at low altitude allow the reservoir to effectively be underpressured so boiling occurs at depth and a zone of steam upflow under vapor-static pressure conditions develops.

Subsurface escape of reservoir fluid southwestward from beneath Valles Caldera has formed a discharge plume of reservoir water mixed with dilute ground water near and beneath Cañon de San Diego, which extends downcanyon in conduits at least as far as Soda Dam and Jemez Springs and brings mineral water to these areas.

An estimated 25-50 percent of the discharge flows laterally toward Cañon de San Diego and is channeled along vertical conduits in the Jemez Fault Zone where the fault zone intersects the caldera. The hot springs in Cañon de San Diego at Soda Dam and Jemez Springs are derivatives of subsurface outflow from the geothermal reservoir. The fault zone transports a large portion of the flow, and the remainder is assumed to be distributed on either side of the fault zone and contained primarily in horizontal, semipermeable sedimentary strata. The lateral extent of discharge from the geothermal reservoir has not been fully defined.

The mineral water from springs at Jemez Springs and Soda Dam has a $\mathrm{Na} \mathrm{Cl}$ composition and large concentrations of $\mathrm{Ca}$ and $\mathrm{HCO}_{3}$. The $\mathrm{Li} / \mathrm{Na}, \mathrm{Li} / \mathrm{Cl}$, and $\mathrm{B} / \mathrm{Cl}$ ratios of the mineral water are in ranges typical of volcanic waters. Differences in temperature and in chemical composition and concentration exist between the mineral water at Jemez Springs and Soda Dam, which indicate flow along different paths and probably differences related to the nature of the dilute water and the location of mixing.
Reservoir fluid from the Sulphur Creek subsystem is the likely geothermal parent of mineral water beneath the Jemez Plateau west of the caldera, based on chemical and stable-isotope data from mineral-water samples collected beneath the plateau. The course the reservoir fluid takes when leaving the plateau has not been established; flow southeastward to Cañon de San Diego is possible but needs further study.

Geophysical evidence indicates a gap in the intrusive rocks of the caldera ring-fracture zone near the site where San Antonio Creek flows out the caldera. The proximity of this site to the Jemez Fault Zone provides a general explanation for escape of reservoir fluid in the subsurface down Cañon de San Diego.

At least two principal or regional aquifers are in the southern Jemez Mountains: the geothermal reservoir(s) in Valles Caldera and associated discharge conduits, and the rift-fill sediments at the southern and southwestern edges of the study area. South and southwest of the caldera rim mineral-water conduits are near the base of the sedimentary section, and in this form, the geothermal aquifer probably extends southward as far as Jemez Pueblo. Near there, subsurface mineral water merges with the regional aquifer in fill deposits of the Rio Grande Rift. The dilute-water aquifer in the east slope of the Sierra Nacimiento west of Jemez Pueblo probably merges to the east with the regional aquifer in fill deposits of the Rio Grande Rift. It is generally assumed that no single reservoir fluid and no single dilute fluid are parents of all derivative mineral water outside the caldera.

All sites of outflowing mineral water appear to be in the western and southwestern parts of the caldera rim. No evidence of escaping geothermal fluid has been found on the northwest or northern flanks of the Jemez Mountains, and the stable-isotope composition of ground water rules out leakage to the east.

Mineral water in the southern Sierra Nacimiento and near San Ysidro is derived from a separate lowtemperature geothermal system along the Nacimiento Fault Zone rather than from a Valles Caldera parent. The Nacimiento water comes from or through limestone and gypsum-bearing rocks and is characterized by large concentrations of $\mathrm{HCO}_{3}, \mathrm{SO}_{4}$, $\mathrm{Cl}, \mathrm{Li}$, and $\mathrm{B}$. The water mixes near San Ysidro with water moving down Cañon de San Diego. Springs near San Ysidro represent a series of intermediate mixtures. 
Total geothermal discharge from the caldera consists of three components: streamflow, ground water in alluvium beneath the stream channel and canyon floor, and conduit flow in bedrock. Total discharge from the geothermal reservoir is difficult to estimate; all estimates, however, suggest a small discharge of geothermal fluid from the caldera. About $1.0 \mathrm{ft}^{3} / \mathrm{s}$ of caldera-derived geothermal fluid is estimated to be carried by the Jemez River between Jemez Pueblo and San Ysidro, and about $0.4 \mathrm{ft}^{3} / \mathrm{s}$ is estimated to be carried as underflow in the same reach. The estimates do not include any flow in subsurface conduits. Estimates of total discharge from the geothermal reservoir to the Rio Grande at its confluence with the Jemez River, as measured by increases in chemical load, range from 2.0 to $3.6 \mathrm{ft}^{3} / \mathrm{s}$ and average $2.8 \mathrm{ft}^{3} / \mathrm{s}$, but these estimates may include discharge from the Sierra Nacimiento.

The conceptual model of the Valles geothermal system in this study involves a liquid-dominated reservoir with a parasitic vapor-dominated zone. The system contains an upflow zone and a region of twophase (boiling) conditions at which liquid and steam phases separate; steam rises through a vapordominated zone to discharge at high altitudes, and liquid flows laterally to discharge as springs and river seepage at low altitudes. The basic conceptual model of the Valles geothermal system used to develop any future numerical models needs to include the above aspects of the system and account for complications related to heterogeneity in thermodynamic and hydrologic conditions within the reservoir, such as separate productive zones at different depths in the Redondo Creek Graben area and hydrologic separation between the Redondo Creek and the Sulphur Creek areas, which may have separate recharge/discharge subsystems.

Various numerical models of the geothermal system in Valles Caldera and surrounding region have been developed primarily to assess reservoir productivity and longevity and potential effects of development on thermal-water discharge in the Jemez River. Existing numerical models of the system range in complexity from one-dimensional, single-phase fluid-flow models to three-dimensional, multiphasefluid and heat-flow models. The differences in modeling approach resulted in a range of 6.3 to 1,234 $\mathrm{gal} / \mathrm{min}$ for calculated depletion of thermal-water discharge to the Jemez River from 30-year simulations of geothermal development at the 50-megawatt level.
Further, the models simulating possible production and injection scenarios over a 30-year period give considerably different results of predicted reservoir drawdown and reservoir productivity over time. A period of actual geothermal development, in which the system is stressed and the resulting hydrologic changes are measured, is missing. Existing models must be considered preliminary and cannot provide accurate answers to questions involving long-term changes to the geothermal system.

The elements necessary to successfully model the Valles hydrothermal system include (1) threedimensional descriptions of fluid and heat flow that can treat both lateral and vertical heterogeneities; (2) a multiphase thermodynamic and fluid-flow formulation; (3) hydrologic continuity between the geothermal reservoir and the discharge plume of thermal water in areas inside and outside the caldera; (4) capability to allow for variable input rates of high-enthalpy fluid into the geothermal reservoir; and (5) capability to treat different production/injection scenarios as affected by changes in steam fractions in regions around production wells. An existing model has these capabilities, yet is simple enough that it can be used to test combinations of different parameters or to examine the importance of two-phase effects and vertical variations in reservoir properties and fluid (thermodynamic) states in modeling the reservoir response to development.

The concentrations of $\mathrm{CO}_{2}$ in the reservoir fluid have not been adequately delineated from existing sampling and wellhead measurements, but based on what is known, the $\mathrm{CO}_{2}$ concentrations appear to be sufficient to markedly extend the depth over which two-phase conditions occur naturally and possibly to influence reservoir drawdown during development. Existing models do not account for the presence of $\mathrm{CO}_{2}$ in the reservoir fluid. This matter requires further study to allow for more accurate simulation of reservoir performance and longevity during development.

Development of geothermal energy in Valles Caldera would probably change hydrochemical discharge from the southwestern Jemez Mountains. Quantifying such changes, which could be accomplished by systematic monitoring, would be valuable in better understanding the geothermal system and in testing, refining, and calibrating numerical models of the system. 


\section{SELECTED REFERENCES}

Abeyta, C.G., and Delaney, B.M., 1986, Annotated bibliography of the hydrology, geology, and geothermal research of the Jemez Mountains and vicinity, northcentral New Mexico: U.S. Geological Survey OpenFile Report 85-83, 155 p.

1990, Hydrologic data for the Jemez Mountains, New Mexico: U.S. Geological Survey Open-File Report 90-176, $51 \mathrm{p}$.

Aldrich, M.J., Jr., 1986, Tectonics of the Jemez lineament in the Jemez Mountains and Rio Grande Rift: Journal of Geophysical Research, v. 91, no. B2, p. 1753-1762.

American Ground Water Consultants, Inc., 1980a, Hydrogeology of the Hot Dry Rock site at Fenton Hill, Sandoval County, New Mexico: Report to Los Alamos Scientific Laboratory.

1980b, Results of ground-water model studies at Fenton Hill, Sandoval County, New Mexico: Report to Los Alamos Scientific Laboratory.

Anderholm, S.K., 1988, Ground-water geochemistry of the Albuquerque-Belen Basin, central New Mexico: U.S. Geological Survey Water-Resources Investigations Report 86-4094, 110 p.

Bailey, R.A., 1961, Hot spring and solfataric areas in the Valles Caldera, Jemez Mountains, New Mexico: U.S. Geological Survey Open-File Map, scale 1:62,500.

Balleau, W.P., 1980, Geothermal hydrology at Jemez Mountains-Ion balance and flow depletion: Albuquerque, N. Mex., Bureau of Indian Affairs unpublished report, $16 \mathrm{p}$.

Becker, N.M., Purtymun, W.D., and Ballance, W.C., 1981, Aquifer evaluation at Fenton Hill, October and November 1980: Los Alamos National Laboratory Report LA-8964-MS.

Bodvarsson, G.S., Vonder Haar, S., Wilt, M.J., and Tsang, C.F., 1982, Preliminary studies of the reservoir capacity and generating potential of the Baca geothermal field, New Mexico: Water Resources Research, v. 18, p. 1713-1723.

Charles, R.W., Vidale Buden, R.J., and Goff, Fraser, 1986, An interpretation of the alteration assemblages at Sulphur Springs, Valles Caldera, New Mexico: Journal of Geophysical Research, v. 91, no. B2, p. 1887-1898.

Clark, J.D., 1929, The saline springs of the Rio Salado: Albuquerque, University of New Mexico Bulletin, Chemistry Series, v. 1, no. 3, 29 p.

Clark, S.P., Jr., ed., 1966, Handbook of physical constants (rev. ed.): Geological Society of America Memoir 97, $587 \mathrm{p}$.

Conover, C.S., Theis, C.V., and Griggs, R.L., 1963, Geology and hydrology of Valle Grande and Valle Toledo, Sandoval County, New Mexico: U.S. Geological Survey Water-Supply Paper 1619-Y, 37 p.
Craigg, S.D., 1984, Hydrologic data on the Pueblos of Jemez, Zia, and Santa Ana, Sandoval County, New Mexico: U.S. Geological Survey Open-File Report 84$460,37 \mathrm{p}$.

-1992, Water resources on the Pueblos of Jemez, Zia, and Santa Ana, Sandoval County, New Mexico: U.S. Geological Survey Water-Resources Investigations Report 89-4091, 122 p.

Dash, Z.V., Murphy, H.D., Aamodt, R.L., Aguilar, R.G., Brown, D.W., Counce, D.A., Fisher, H.N., Grigsby, C.O., Keppler, H., Laughlin, A.W., Potter, R.M., Tesfer, J.W., Trujillo, P.E., Jr., and Zyvoloski, G., 1983, Hot dry rock geothermal reservoir testing, 1978 to 1980 :

Journal Volcanology and Geothermal Research, v. 15, p. 59-99.

Delany, J.M., and Truesdell, A.H., 1982, Geochemical indicators of reservoir conditions, in Goldstein, N.E., Holman, W.R., and Molloy, M.W., eds., Final report of the Department of Energy reservoir definition review team for the Baca geothermal demonstration project: University of California, Lawrence Berkeley Laboratory Report LBL-14132, p. 18-21.

Doell, R.R., Dalrymple, G.B., Smith, R.L., and Bailey, R.A., 1968, Paleomagnetism, potassium-argon ages, and geology of rhyolites and associated rocks of the Valles Caldera, New Mexico, in Coats, R.R., and others, eds., Studies in volcanology: Geological Society of America Memoir 116, p. 211-248.

Dondanville, R.F., 1971, The hydrothermal geology of the Valles Caldera, Jemez Mountains, New Mexico: Consultant's report to Union Oil Company of California, Santa Rosa, Calif. (released 1978), 36 p. 1978, Geologic characteristics of the Valles Caldera geothermal system, New Mexico: Geothermal Resources Council Transactions, v. 2, sec. 1, p. 157160.

Faust, C.R., Mercer, J.W., and Thomas, S.D., 1983, Quantitative analysis of geothermal development in the Jemez Mountains, final report: Contract MOOC14203411, Bureau of Indian Affairs, Albuquerque, N. Mex., 87 p. and 5 app.

Faust, C.R., Mercer, J.W., Thomas, S.D., and Balleau, W.P., 1984, Quantitative analysis of existing conditions and production strategies for the Baca geothermal system, New Mexico: Water Resources Research, v. 20, no. 5, p. 601-618.

Galusha, Ted, and Blick, J.C., 1971, Stratigraphy of the Santa Fe Group, New Mexico: American Museum of Natural History Bulletin, v. 144, article 1, 127 p.

Gardner, J.N., Goff, Fraser, Garcia, Sammy, and Hagan, R.C., 1986, Stratigraphic relations and lithologic variations in the Jemez volcanic field, New Mexico: Journal of Geophysical Research, v. 91, no. B2, p. $1763-1778$. 
Garg, Sabodh, and Riney, T.D., 1982, Reservoir definition and conceptual model, in Goldstein, N.E., Holman, W.R., and Molloy, M.W., eds., Final report of the Department of Energy reservoir definition review team for the Baca geothermal demonstration project: University of California, Lawrence Berkeley Laboratory Report LBL-14132, p. 31-36.

Goff, Fraser, Gardner, J.N., Hulen, J.B., Nielson, D.L., Charles, Robert, WoldeGabriel, Giday, Vuataz, F.D., Musgrave, J.A., Shevenell, Lisa, and Kennedy, B.M., 1992, The Valles caldera hydrothermal system, past and present, New Mexico, USA: Springer-Verlag, Scientific Drilling, v. 3, p. 181-204.

Goff, Fraser, Gardner, Jamie, Vidale, Rosemary, and Charles, Robert, 1985, Geochemistry and isotopes of fluids from Sulphur Springs, Valles Caldera, New Mexico: Journal of Volcanological and Geothermal Research, v. 23, p. 273-297.

Goff, Fraser, and Grigsby, C.O., 1982, Valles Caldera geothermal systems, New Mexico, U.S.A.: Journal of Hydrology, v. 56, p. 119-136.

Goff, F.E., Grigsby, C.O., Trujillo, P.E., Jr., Counce, Dale, and Kron, Andrea, 1981, Geology, water geochemistry, and geothermal potential of the Jemez Springs area, Cañon de San Diego, New Mexico: Journal of Volcanology and Geothermal Research, v. 10, p. 227 244.

Goff, F.E., and Kron, Andrea, 1980, In-progress geologic map of Cañon de San Diego, Jemez Springs, New Mexico, and lithologic log of Jemez Springs geothermal well: Los Alamos Scientific Laboratory Informal Map LA-8276-MAP, one sheet, scale $1: 12,000$.

Goff, F.E., McCormick, Tamsin, Trujillo, P.E., Jr., Counce, Dale, and Grigsby, C.O., 1982, Geochemical data for 95 thermal and nonthermal waters of the Valles caldera-Southern Jemez Mountains region New Mexico: University of California, Los Alamos National Laboratory Report LA-9367-OBES, 51 p.

Goff, Fraser, Rowley, John, Gardner, J.N., Hawkins, Ward, Goff, Sue, Charles, Robert, Wachs, Daniel, Maasseu, Larry, and Heiken, Grant, 1986, Initial results from VC1 , first Continental Scientific Drilling Program core hole in Valles caldera, New Mexico: Journal of Geophysical Research, v. 91, no. B2, p. 1742-1752.

Goff, F.E., and Sayer, Suzanne, 1980, A geothermal investigation of spring and well waters of the Los Alamos region, New Mexico: Los Alamos National Laboratory Informal Report LA-8326-MS, 21 p.

Goff, Fraser, and Shevenell, Lisa, 1987, Travertine deposits of Soda Dam, New Mexico, and their implications for the age and evolution of the Valles caldera hydrothermal system: Geological Society of America Bulletin, v. 99, p. 292-302.
Goff, Fraser, Shevenell, Lisa, Gardner, J.N., Vuataz, F.D., and Grigsby, C.O., 1988, The hydrothermal outflow plume of the Valles Caldera, New Mexico, and a comparison with other outflow plumes: Journal of Geophysical Research, v. 93, no. B6, p. 6041-6058.

Goldstein, N.E., Holman, W.R., and Molloy, M.W., eds., 1982, Final report of the Department of Energy reservoir definition review team for the Baca geothermal demonstration project: University of California, Lawrence Berkeley Laboratory LBL-14132, $51 \mathrm{p}$.

Grant, M.A., 1979, Interpretation of downhole measurements at Baca: Proceedings of the 8th Geothermal Workshop, Stanford University, Palo Alto, Calif., p. 261-267.

Grant, M.A., Garg, S.K., and Riney, T.D., 1984, Interpretation of downhole data and development of a conceptual model for the Redondo Creek area of the Baca geothermal field: Water Resources Research, v. 20 , no. 10 , p. 1401-1416.

Griggs, R.L., 1964, Geology and ground-water resources of the Los Alamos area, New Mexico, with a section on Quality of water, by J.D. Hem: U.S. Geological Survey Water-Supply Paper 1753, $107 \mathrm{p}$.

Grigsby, C.O., Goff, Fraser, Trujillo, P.E., and Counce, D.A., 1984, Geochemical behavior of a hot dry rock geothermal reservoir: Socorro, New Mexico Geological Society Field Conference Guidebook, 35th Field Conference, p. 265-270.

Hartz, J.D., 1976, Geothermal reservoir evaluation of the Redondo Creek area, Sandoval County, New Mexico: Internal report, Union Oil Company, Santa Rosa, Calif.

Heiken, Grant, Goff, Fraser, Stix, John, Tamanyu, Shiro, Shafiqullah, Muhammad, Garcia, Sammy, and Hagan, Roland, 1986, Intracaldera volcanic activity, Toledo Caldera and embayment, Jemez Mountains, New Mexico: Journal of Geophysical Research, v. 91, no. B2, p. 1799-1815.

Hem, J.D., 1970, Study and interpretation of the chemical characteristics of natural water ( $2 \mathrm{~d}$ ed.): U.S. Geological Survey Water-Supply Paper 1473, 363 p.

Hulen, J.B., 1982, Structure, stratigraphy, and permeability in the Redondo Creek project area, in Goldstein, N.E., Holman, W.R., and Molloy, M.W., eds., Final report of the Department of Energy reservoir definition review team for the Baca geothermal demonstration project: University of California, Lawrence Berkeley Laboratory Report LBL-14132, p. 7-14.

Hulen, J.B., and Nielson, D.L., 1986, Hydrothermal alteration in the Baca geothermal system, Redondo dome, Valles Caldera, New Mexico: Journal of Geophysical Research, v. 91, no. B2, p. 1867-1886.

Ingebritsen, S.E., and Sorey, M.L., 1985, A quantitative analysis of the Lassen hydrothermal system, north- 
central California: Water Resources Research, v. 21, no. 6, p. 853-868.

Jiracek, G.R., 1974, Geophysical studies in the Jemez Mountains region, New Mexico: Socorro, New Mexico Geological Society Guidebook, 25th Field Conference, p. 137-144.

-1975, Deep electrical resistivity investigations coupled with dry geothermal reservoir experiments in New Mexico: Albuquerque, University of New Mexico Technical Progress Report to U.S. National Science Foundation/RANN, Contract NSF GI-42835, 47 p.

Jiracek, G.R., Smith, C., and Dorn, G.A., 1975, Deep geothermal exploration in New Mexico using electrical resistivity: Second United Nations Symposium on the Development and Use of Geothermal Resources, Proceedings, v. 2, p. 1095-1102.

John, E.C., Enyart, E.A., and Purtymun, W.D., 1967, Records of wells, test holes, springs, and surface-water stations in the Los Alamos area, New Mexico: U.S. Geological Survey Open-File Report, 129 p.

Journal of Geophysical Research, 1986, including Special Section-Recent research in the Valles Caldera: American Geophysical Union, v. 91, no. B2, p. 17412218.

-1988, including Special Section-Research in the Valles Caldera: American Geophysical Union, v. 93, no. B6, p. 5997-6668.

Kelley, V.C., 1969, Albuquerque-Its mountains, valley, water, and volcanoes: Socorro, New Mexico Bureau of Mines and Mineral Resources, Scenic Trips to the Geologic Past, no. 9, 101 p.

Kelly, Clyde, and Anspach, E.V., 1913, A preliminary study of the waters of the Jemez Plateau, New Mexico: Albuquerque, University of New Mexico Bulletin, Chemistry Series, v. 1, no. 1, 43 p.

Kelly, T.E., and Reinert, Scott, 1996, Arsenic stratification in the Santa Fe Formation, Bernalillo, New Mexico: New Mexico Geological Society Guidebook, 47th Annual Field Conference, Jemez Mountains Region, p. 481484.

Kunkel, K.E., 1984, Temperature and precipitation summaries for selected New Mexico locations: Las Cruces, Office of the State Climatologist, New Mexico Department of Agriculture, $190 \mathrm{p}$.

Lambert, S., and Epstein, S., 1980, Stable isotope investigation of an active geothermal system in Valles Caldera, New Mexico: Journal of Volcanology and Geothermal Research, v. 8, p. 111-129.

Mariner, R.H., Presser, T.S., and Evans, W.C., 1977, Chemical, isotope, and gas composition of selected thermal springs in Arizona, New Mexico, and Utah: U.S. Geological Survey Open-File Report 77-654, 56 p.

New Mexico Environment Department, 1991, Special waterquality survey of the Rio Grande from Angostura diversion works to I-25 in Sandoval and Bernalillo
Counties, New Mexico, June 18-September 18, 1991, in Intensive water-quality stream surveys and lake waterquality assessment surveys: New Mexico Environment Department Report NMED/SWQ-92/2, p. 118-149.

New Mexico State Engineer Office, 1980, Report and recommendation of Hearing Examiner in the matter of application of Marcel and Thomas Abousleman number 02541B and RG-32624 for an alternate point of diversion and new place and purpose of use from surface water to geothermal water and to appropriate the underground waters of the State of New Mexico, Bernalillo, N. Mex., April 10-11, 1980: 9 p.

Nielson, D.L., and Hulen, J.B., 1984, Internal geology and evolution of the Redondo dome, Valles Caldera, New Mexico: Journal of Geophysical Research, v. 89, no. B10, p. 8695-8711.

Pearson, Chris, and Goff, Fraser, 1981, A Schlumberger resistivity study of the Jemez Springs region of northwestern New Mexico: Geothermal Resources Council Transactions, v. 5, p. 119-122.

Pettitt, R.A., 1975a, Planning, drilling, and logging of Geothermal Test Hole GT-2, Phase I: Los Alamos Scientific Laboratory Progress Report LA-5819-PR, $42 \mathrm{p}$.

1975b, Testing, drilling, and logging of Geothermal Test Hole GT-2, Phase II: Los Alamos Scientific Laboratory Progress Report LA-5897-PR, 21 p. 1978, Testing, planning, and redrilling of Geothermal Test Hole GT-2, Phases IV and V: Los Alamos Scientific Laboratory Progress Report LA7586-PR, $60 \mathrm{p}$.

Pierce, S.T., 1989, Intensive water-quality survey of the Rio Grande from Angostura to U.S. 85 bridge, Sandoval and Bernalillo Counties, New Mexico, July 25-28, 1988: New Mexico Environmental Improvement Division Report EID/SWQ-8816, 51 p.

Pritchett, J.W., Rice, L.F., and Riney, T.D., 1981, Effects of $\mathrm{CO}_{2}$ content on geothermal systems-Implications for Baca reservoir: Transactions of the Geothermal Resources Council, v. 5, p. 369-372.

Purtymun, W.D., Adams, W.H., and Owens, J.W., 1975, Water quality in vicinity of Fenton Hill site, 1974: Los Alamos Scientific Laboratory Report LA-6093, 16 p.

Purtymun, W.D., Adams, W.H., and Stoker, A.K., 1978, Water quality in vicinity of Fenton Hill site, 1976: Los Alamos Scientific Laboratory Informal Report LA7307-MS, 17 p.

Purtymun, W.D., Adams, W.H., Stoker, A.K., and West, F.G., 1976, Water quality in vicinity of Fenton Hill site, 1975: Los Alamos Scientific Laboratory Informal Report LA-6511-MS, 21 p.

Purtymun, W.D., and Cooper, J.B., 1969, Development of ground-water supplies on the Pajarito Plateau, Los Alamos County, New Mexico: U.S. Geological Survey Professional Paper 650-B, p. B149-B153. 
Purtymun, W.D., Ferenbaugh, R.W., and Adams, W.H., 1981, Water quality in the vicinity of Fenton Hill, 1980: Los Alamos National Laboratory Progress Report LA9007-PR, 16 p.

Purtymun, W.D., Ferenbaugh, R.W., Becker, N.M., Adams, W.H., and Maes, M.N., 1983, Water quality in the vicinity of Fenton Hill, 1981 and 1982: Los Alamos National Laboratory Progress Report LA-9854-PR, $30 \mathrm{p}$.

Purtymun, W.D., Ferenbaugh, R.W., Becker, N.M., Williams, M.C., and Maes, M.N., 1987, Water quality in the vicinity of Fenton Hill, 1983 and 1984: Los Alamos National Laboratory Progress Report LA10892-PR, $37 \mathrm{p}$.

Purtymun, W.D., Ferenbaugh, R.W., Stoker, A.K., and Adams, W.H., 1980a, Water quality in the vicinity of Fenton Hill, 1979: Los Alamos Scientific Laboratory Progress Report LA-8424-PR, 21 p.

Purtymun, W.D., Ferenbaugh, R.W., Stoker, A.K., Adams, W.H., and Owens, J.W., 1980b, Water quality in the vicinity of Fenton Hill, 1978: Los Alamos Scientific Laboratory Progress Report LA-8217-PR, 21 p.

Purtymun, W.D., Ferenbaugh, R.W., Williams, M.C., and Maes, M.N., 1988, Water quality in the vicinity of Fenton Hill, 1985 and 1986: Los Alamos National Laboratory Progress Report LA-11210-PR, 36 p.

Purtymun, W.D., and Johansen, Steven, 1974, General geohydrology of the Pajarito Plateau: New Mexico Geological Society Guidebook, 25th Field Conference, p. 347-349.

Purtymun, W.D., Stoker, A.K., Adams, W.H., and Owens, J.W., 1978: Water quality in the vicinity of Fenton Hill site, 1977: Los Alamos Scientific Laboratory Progress Report LA-7468-PR, $16 \mathrm{p}$.

Purtymun, W.D., West, F.G., and Adams, W.H., 1974, Preliminary study of the quality of water in the drainage area of the Jemez River and Rio Guadalupe: Los Alamos Scientific Laboratory Informal Report LA5595-MS, $26 \mathrm{p}$.

Reiter, Marshall, Edwards, C.L., Hartman, Harold, and Weidman, Charles, 1975, Terrestrial heat flow along the Rio Grande Rift, New Mexico and southern Colorado: Geological Society of America Bulletin, v. 86, no. 6, p. 811-818.

Reiter, Marshall, Shearer, Charles, and Edwards, C.L., 1978, Geothermal anomalies along the Rio Grande Rift, New Mexico: Geology, v. 6, p. 85-88.

Reiter, Marshall, Shearer, Charles, Edwards, C.L., and Hartman, Harold, 1976, Subsurface temperature data in Jemez Mountains, New Mexico: Socorro, New Mexico Bureau of Mines and Mineral Resources Circular 151, $16 \mathrm{p}$.

Renick, B.C., 1931, Geology and ground-water resources of western Sandoval County, New Mexico: U.S. Geological Survey Water-Supply Paper 620,117 p.
Sass, J.H., and Morgan, Paul, 1988, Conductive heat flux in VC- 1 and the thermal regime of Valles caldera, Jemez Mountains, New Mexico: Journal of Geophysical Research, v. 91, no. B6, p. 6027-6039.

Self, Stephen, Goff, Fraser, Gardner, J.N., Wright, J.V., and Kite, W.M., 1986, Explosive rhyolitic volcanism in the Jemez Mountains-Vent locations, caldera development, and relation to regional structure: Journal of Geophysical Research, v. 91, no. B2, p. 1779-1798.

Self, Stephen, Heiken, Grant, Sykes, M.L., Wohletz, Kenneth, Fisher, R.V., and Dethier, D.P., 1996, Field excursions to the Jemez Mountains, New Mexico: Socorro, New Mexico Bureau of Mines and Mineral Resources Bulletin 134, 72 p.

Shevenell, Lisa, Goff, Fraser, Miles, Dan, Waibel, Al, and Swanberg, Chandler, 1988, Lithologic descriptions and temperature profiles of five wells in the southwestern Valles caldera region, New Mexico: Los Alamos National Laboratory Report LA-11165-OBES, 43 p.

Shevenell, Lisa, Goff, Fraser, Vuataz, F.D., Trujillo, P.E., Jr., Counce, D., Janick, C. J., and Evans, B., 1987, Hydrogeochemical data for the thermal and nonthermal waters and gases of the Valles Caldera-Southern Jemez Mountains region, New Mexico: Los Alamos National Laboratory Report LA-10923-OBES, $100 \mathrm{p}$.

Smith, R.L., and Bailey, R.A., 1968, Resurgent cauldrons, in Coats, R.R., and others, eds., Studies in volcanology: Geological Society of America Memoir 116, p. 613622.

Smith, R.L., Bailey, R.A., and Ross, C.S., 1961, Structural evolution of the Valles caldera, New Mexico, and its bearing on the emplacement of ring dikes: U.S. Geological Survey Professional Paper 424-D, p. D145D149.

1970, Geologic map of the Jemez Mountains, New Mexico: U.S. Geological Survey Miscellaneous Geologic Investigations Map I-571, scale 1:125,000.

Smith, S.P., and Kennedy, B.M., 1985, Noble gas evidence for two fluids in the Baca (Valles Caldera) geothermal reservoir: Geochimica et Cosmochimica Acta, v. 49, p. 893-902.

Sorey, M.L., 1985, Evolution and present state of the hydrothermal system in Long Valley Caldera: Journal of Geophysical Research, v. 90, no. B13, p. 1121911228.

Spiegel, Zane, 1962, Domestic water supply for Jemez, New Mexico: Unpublished report to U.S. Public Health Service, Albuquerque, N. Mex., 12 p.

Summers, W.K., 1976, Catalog of thermal waters in New Mexico: Socorro, New Mexico Bureau of Mines and Mineral Resources Hydrologic Report 4, 80 p.

Swanberg, C.A., 1983, Geothermal resources of rifts-A comparison of the Rio Grande Rift and the Salton Trough: Tectonophysics, v. 94, p. 659-678. 
Trainer, F.W., 1974, Ground water in the southwestern part of the Jemez Mountains volcanic region, New Mexico: Socorro, New Mexico Geological Society Guidebook, 25th Field Conference, p. 337-345.

1975, Mixing of thermal and nonthermal waters in the margin of the Rio Grande Rift, Jemez Mountains, New Mexico: Socorro, New Mexico Geological Society Guidebook, 26th Field Conference, p. 213-218.

-1978 , Geohydrologic data from the Jemez Mountains and vicinity, north-central New Mexico: U.S. Geological Survey Water-Resources Investigations 77$131,146 \mathrm{p}$.

1984, Thermal mineral springs in Cañon de San Diego as a window into Valles Caldera, New Mexico: Socorro, New Mexico Geological Society Guidebook, 35 th Field Conference, p. 249-255.

Trainer, F.W., and Lyford, F.P., 1979, Geothermal hydrology in the Rio Grande Rift, north-central New Mexico: Socorro, New Mexico Geological Society Guidebook, 30th Field Conference, p. 299-306.

Truesdell, A.H., and Janik, C.J., 1986, Reservoir processes and fluid origins in the Baca geothermal system, Valles Caldera, New Mexico: Journal of Geophysical Research, v. 91, no. B2, p. 1817-1833.

Union Geothermal Company of New Mexico, 1981, Computer modeling of potential impacts of $50 \mathrm{Mwe}$ commercial development of the Redondo Creek geothermal field, New Mexico, upon geothermal fluids discharge into the Jemez River: Internal report, Rio Rancho, N. Mex.

Union Oil Company of California and Public Service Company of New Mexico, 1978, Geothermal demonstration power plant, v. 2, Technical and management proposal: Submitted to U.S. Department of Energy in response to Program Opportunity Notice EG-77-NO-3-1717, 31 January 1978.

U.S. Department of Energy, 1980, Final Environmental Impact Statement, Geothermal Demonstration Program, 50 MWe power plant, Sandoval and Rio Arriba Counties, New Mexico: U.S. Department of Energy Environmental Impact Statement DOE/EIS0049.

U.S. Environmental Protection Agency, 1977, National interim primary drinking water regulations: Office of Water Supply Report EPA-570/9-76-003, 159 p.

U.S. Geological Survey, 1963 and 1964, Surface water records of New Mexico: Santa Fe, N. Mex.

1965 through 1974, Water resources data for New Mexico: Part 1. Surface water records, Part 2, Water quality records, Albuquerque, N. Mex.

1975 through 1983, Water resources data for New Mexico: U.S. Geological Survey Water-Data Reports NM-74-1 through NM-82-1, Albuquerque, N. Mex.
U.S. Soil Conservation Service, 1972, Normal annual precipitation, New Mexico: Soil Conservation Service, U.S. Department of Agriculture map, scale 1:500,000.

Vuataz, F.D., and Goff, Fraser, 1986, Isotope geochemistry of thermal and nonthermal waters in the Valles caldera, Jemez Mountains, northern New Mexico: Journal of Geophysical Research, v. 91, no. B2, p. 1835-1853.

Vuataz, F.D., Goff, Fraser, Fouillac, Christian, and Calvez, Jean-Yves, 1988, A strontium isotope study of the VC1 core hole and associated hydrothermal fluids and rocks from Valles caldera, Jemez Mountains, New Mexico: Journal of Geophysical Research, v. 93, no. B6, p. 6059-6067.

Water Resources Associates, Inc., 1977, Hydrology-Jemez Mountains, New Mexico: Scottsdale, Ariz., report prepared for Union Oil Company, 26 p., 3 app. (1978).

West, F.G., 1974, Dry hot rock project: Socorro, New Mexico Geological Society Guidebook, 25th Field Conference, p. 355-358.

West, F.G., Kintzinger, P.R., and Purtymun, W.D., 1975, Hydrologic testing Geothermal Test Hole No. 2: Los Alamos Scientific Laboratory Informal Report LA6017-MS, 8 p.

White, A.F., 1986, Chemical and isotopic characteristics of the fluids within the Baca geothermal reservoir, Valles Caldera, New Mexico: Journal of Geophysical Research, v. 91, no. B2, p. 1855-1866.

White, A.F., Delany, J.M., Truesdell, Alfred, Janik, Kathy, Goff, Fraser, and Crecraft, Harrison, 1984, Fluid chemistry of the Baca geothermal field, Valles caldera, New Mexico: Socorro, New Mexico Geological Society Field Conference Guidebook No. 35, p. 257 263.

White, D.E., 1957, Magmatic, connate, and metamorphic waters: Geological Society of America Bulletin, v. 68, p. 1659-1682.

White, D.E., Hem, J.D., and Waring, G.A., 1963, Chemical composition of subsurface waters: U.S. Geological Survey Professional Paper 440-F, 67 p.

Wilt, Michael, and Vonder Haar, Stephen, 1986, A geological and geophysical appraisal of the Baca geothermal field, Valles Caldera, New Mexico: Journal of Volcanology and Geothermal Research, v. 27, p. 349 370.

Woltz, David, 1972, The chemistry of groundwaters in the Jemez area and a magnetic survey of a potential source of magnetic fluids: Albuquerque, University of New Mexico, unpublished M.S. thesis, $90 \mathrm{p}$.

Wood, G.H., and Northrop, S.A., 1946, Geology of the Nacimiento Mountains, San Pedro Mountain, and adjacent plateaus in parts of Sandoval and Rio Arriba Counties, New Mexico: U.S. Geological Survey Oil and Gas Investigations Map OM-57, scale 1:95,040. 
U.S. Department of the Interior

U.S. Geological Survey, WRD

5338 Montgomery Blvd. NE, Suite 400

Albuquerque, NM 87109-1311

BOOK RATE

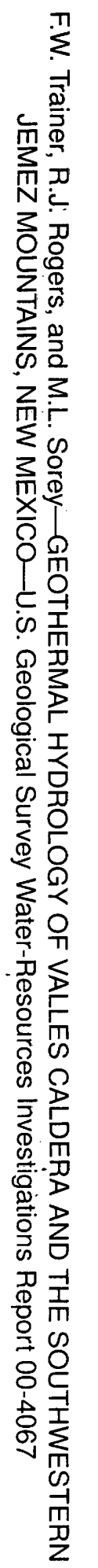

(4) Printed on recycled paper 